\title{
Palladium(II)-Catalyzed Regioselective syn-Hydroarylation of Disubstituted Alkynes Using a Removable Directing Group
}

\author{
Zhen Liu, Joseph Derosa, and Keary M. Engle* \\ Department of Chemistry, The Scripps Research Institute, 10550 North Torrey Pines Road, La \\ Jolla, California 92037,United States
}

SUPPORTING INFORMATION

Table of Contents

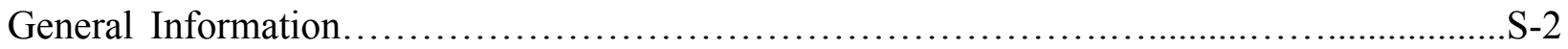

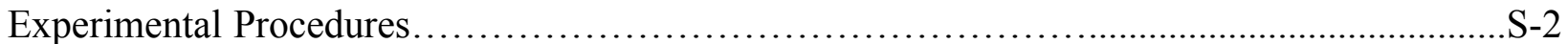

Synthesis of 4-Phenyl Homopropargyl Amines with Various Directing Groups..........S-2

Synthesis of 4-Aryl Homopropargyl Picolinamide Substrates 1a-k, 1w, and 1x.........S-9

Synthesis of Branched Homopropargyl Picolinamide Substrates 1l and 1m..........S-13

Synthesis of Alkynyl Picolinamides with Different Chain Lengths (1n, 1o, and 1u)..S-17

Synthesis of 4-Alkyl and 4-TMS Homopropargyl Picolinamide Substrates 1p-t...... S-20

General Procedure for Hydroarylation of Alkynyl Picolinamides.................................. -23

Determination of Regioselectivity by ${ }^{1} \mathrm{H}$ NMR.......................................................

Characterization of Products in Directing Group Optimization.................................S-38

General Method for Removal of Picolinamide Directing Group........................S-42

Procedure for the Deuterium-Labeling Experiment................................ -42

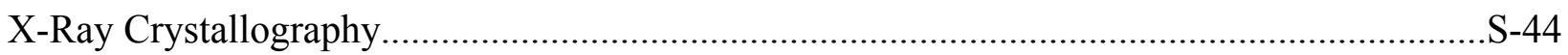

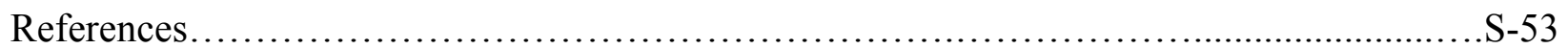

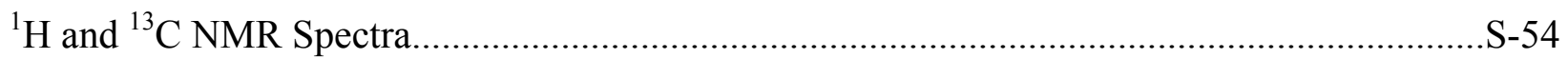

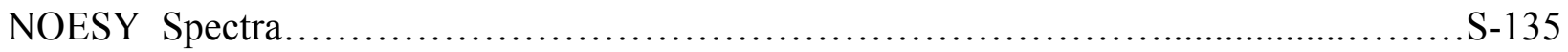




\section{GENERAL INFORMATION}

Unless otherwise noted, all materials were used as received from commercial sources without further purification. All amines, acid chlorides, and solvents were purchased from Aldrich, Alfa Aesar, Oakwood, and Combi-Blocks. In air- or moisture-sensitive reactions, anhydrous solvents from a Grubbs-type solvent purification system were used. Alkyne substrate $\mathrm{N}$-benzyl-4-phenylbut-3-yn-1-amine (1v) was prepared following a literature procedure. ${ }^{1}{ }^{1} \mathrm{H}$ and ${ }^{13} \mathrm{C}$ spectra were recorded with Bruker DRX-500 and AV-600. Spectra were internally referenced to $\mathrm{SiMe}_{4}$ or solvent signals. The following abbreviations (or combinations thereof) were used to explain multiplicities: $\mathrm{b}=$ broad, $\mathrm{s}=$ singlet, $\mathrm{d}=$ doublet, $\mathrm{t}=$ triplet, $\mathrm{q}=$ quartet, hept $=$ heptet and $\mathrm{m}=$ multiplet. High-resolution mass spectra (HRMS) for substrates and new compounds were recorded on an Agilent LC/MSD TOF mass spectrometer.

\section{EXPERIMENTAL PROCEDURES}

Synthesis of 4-Phenyl Homopropargyl Amines with Various Directing Groups:

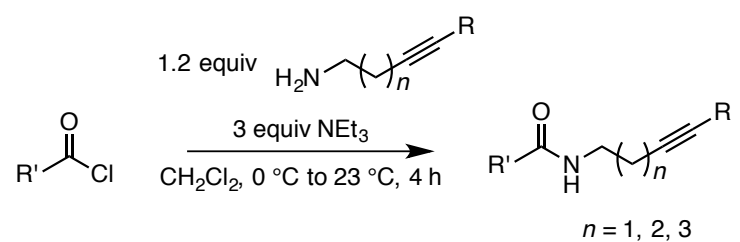

Scheme S1: General depiction of condensation of alkynyl amine with acid chloride.

General Procedure for Amide Synthesis: To a 250-mL round-bottom flask equipped with a Teflon-coated magnetic stir bar were added acid chloride $(10.0 \mathrm{mmol})$ and anhydrous dichloromethane $(50 \mathrm{~mL})$. After the solution was stirred for 15 minutes at $0{ }^{\circ} \mathrm{C}$ in an ice bath, the appropriate amine $(12.0 \mathrm{mmol})$ was added dropwise, followed by dropwise addition of triethylamine $(30.0 \mathrm{mmol})$. The reaction was allowed to warm to room temperature and stir for 4 h. Upon completion, the reaction mixture was quenched with aqueous $\mathrm{NaHCO}_{3}$ and extracted with DCM $(3 \times 15 \mathrm{~mL})$. The organic extract was then dried with $\mathrm{Na}_{2} \mathrm{SO}_{4}$, filtered, and concentrated in vacuo. The crude amide product was purified by silica gel column chromatography.

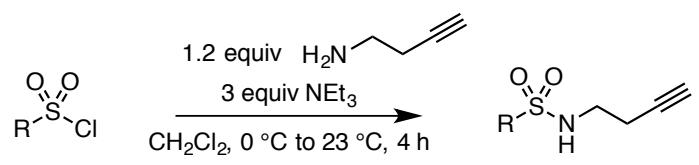

Scheme S2: General depiction of condensation of homopropargyl amine with sulfonyl chloride. 
General Procedure for Sulfonamide Synthesis: To a 250-mL round-bottom flask equipped with a Teflon-coated magnetic stir bar were added sulfonyl chloride $(10.0 \mathrm{mmol})$ and anhydrous dichloromethane $(50 \mathrm{~mL})$. After the solution was stirred for 15 minutes at $0{ }^{\circ} \mathrm{C}$ in an ice bath, the appropriate amine $(12.0 \mathrm{mmol})$ was added dropwise, followed by dropwise addition of triethylamine $(30.0 \mathrm{mmol})$. The reaction was allowed to warm to room temperature and stir for 4 h. Upon completion, the reaction mixture was quenched with aqueous $\mathrm{NaHCO}_{3}$ and extracted with DCM $(3 \times 15 \mathrm{~mL})$. The combined organic extracts were then dried with $\mathrm{Na}_{2} \mathrm{SO}_{4}$, filtered, and concentrated in vacuo. The crude amide product was purified by silica gel column chromatography.

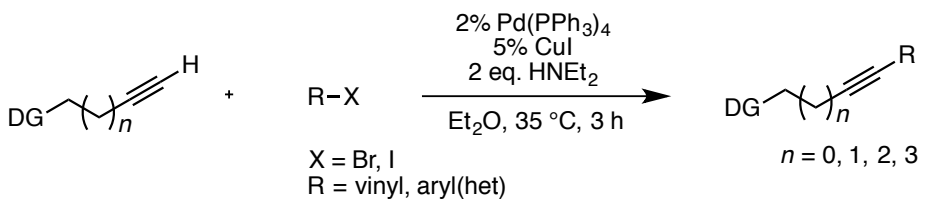

Scheme S3: Synthesis of functionalized alkynes via Sonogashira coupling.

General Procedure for Sonogashira Coupling: To a flame-dried 25-mL round-bottom flask equipped with a Teflon-coated magnetic stir bar were added $\mathrm{Pd}\left(\mathrm{PPh}_{3}\right)_{4}(2 \mathrm{~mol} \%), \mathrm{CuI}(5 \mathrm{~mol} \%)$, the corresponding terminal alkyne $(1 \mathrm{mmol})$, and anhydrous diethyl ether $(3 \mathrm{~mL})$. After the addition of the solvent, the solution was stirred for $10 \mathrm{~min}$ at room temperature followed by the slow addition of appropriate aryl iodide (1.1-1.3 equiv). Diethylamine (2 equiv) was added dropwise and the reaction was allowed to stir at $35^{\circ} \mathrm{C}$ for 3 hours. Upon completion, the reaction mixture was poured carefully into a separatory funnel containing brine and extracted with $\mathrm{Et}_{2} \mathrm{O}$ $(3 \times 10 \mathrm{~mL})$. The combined organic extracts were then dried with $\mathrm{Na}_{2} \mathrm{SO}_{4}$, filtered, and concentrated in vacuo. The crude amide product was purified by silica gel column chromatography.

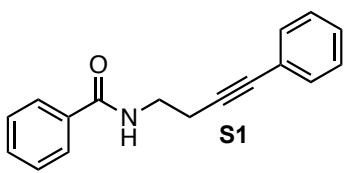

N-(4-phenylbut-3-yn-1-yl)benzamide (S1): The title compound was prepared using $N$-(but-3-yn-1-yl) benzamide (1.39 g, $8.0 \mathrm{mmol}$ ) and iodobenzene $(1.795 \mathrm{~g}, 8.8 \mathrm{mmol})$ according to the general procedure. Purification using silica gel chromatography with 15:1 hexanes:EtOAc as the eluent gave the product as a white solid (1.76 g, 88\% yield). ${ }^{1} \mathbf{H}$ NMR $\left(500 \mathrm{MHz}, \mathrm{CDCl}_{3}\right) \delta$ 7.82-7.76 (m, 2H), 7.54-7.37 (m, 5H), 7.33-7.24 (m, 3H), 6.51 (bs, 1H), 3.70 (q, $J=6.3 \mathrm{~Hz}$, 2H), $2.76(\mathrm{t}, J=6.4 \mathrm{~Hz}, 2 \mathrm{H}) ;{ }^{13} \mathrm{C}$ NMR $\left(125 \mathrm{MHz}, \mathrm{CDCl}_{3}\right) \delta 167.52,134.50,131.61,131.50$, 128.58, 128.28, 127.99, 126.89, 123.23, 86.81, 82.32, 38.73, 20.47; HRMS (ESI-TOF) Calcd for $\mathrm{C}_{17} \mathrm{H}_{16} \mathrm{NO}^{+}[\mathrm{M}+\mathrm{H}]^{+}$250.1226, found 250.1227 .

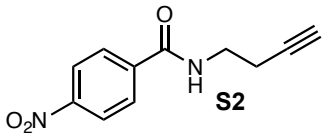

N-(but-3-yn-1-yl)-4-nitrobenzamide (S2): The title compound was prepared using 4-nitrobenzoyl chloride (4.45 g, $24.0 \mathrm{mmol})$ and 
3-butynylamine (1.38 g, $20.0 \mathrm{mmol})$ according to the general procedure. Purification using silica gel chromatography with 5:1 hexanes:EtOAc as the eluent gave the product as an amorphous white solid (2.43 g, 55\% yield). ${ }^{1} \mathbf{H}$ NMR (500 MHz, $\left.\mathrm{CDCl}_{3}\right) \delta 8.30(\mathrm{~d}, J=8.7 \mathrm{~Hz}, 2 \mathrm{H}), 7.95(\mathrm{~d}$, $J=8.8 \mathrm{~Hz}, 2 \mathrm{H}), 6.59(\mathrm{~s}, 1 \mathrm{H}), 3.65$ (q, $J=6.2 \mathrm{~Hz}, 2 \mathrm{H}), 2.56\left(\mathrm{td}, J_{1}=6.3 \mathrm{~Hz}, J_{2}=2.6 \mathrm{~Hz}, 2 \mathrm{H}\right)$, $2.08(\mathrm{t}, J=2.6 \mathrm{~Hz}, 1 \mathrm{H}) ;{ }^{13} \mathrm{C}$ NMR $\left(125 \mathrm{MHz}, \mathrm{CDCl}_{3}\right) \delta 165.49,149.65,139.94,128.13,123.85$, 81.10, 70.56, 38.59, 19.33; HRMS (ESI-TOF) Calcd for $\mathrm{C}_{11} \mathrm{H}_{11} \mathrm{~N}_{2} \mathrm{O}_{3}{ }^{+}[\mathrm{M}+\mathrm{H}]^{+}$219.0764, found 219.0763.

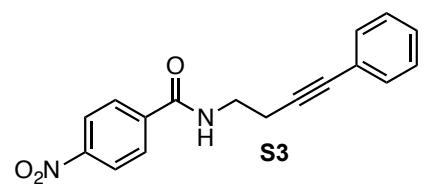

4-nitro- $N$-(4-phenylbut-3-yn-1-yl)benzamide (S3): The title compound was prepared from $N$-(but-3-yn-1-yl)-4- nitrobenzamide (S2) (1.09 g, $5.0 \mathrm{mmol})$ and iodobenzene (1.12 g, $5.5 \mathrm{mmol})$ according to the general procedure. Purification using silica gel chromatography with 3:1 hexanes:EtOAc as the eluent gave the product as a yellow solid (1.06 g, 72\% yield). ${ }^{1} \mathbf{H}$ NMR (500 MHz, $\left.\mathrm{CDCl}_{3}\right) \delta 8.29(\mathrm{~d}, J=4.5 \mathrm{~Hz}, 2 \mathrm{H}), 7.95(\mathrm{~d}, J=4.5 \mathrm{~Hz}, 2 \mathrm{H})$, $7.39(\mathrm{~m}, 2 \mathrm{H}), 7.31(\mathrm{~m}, 3 \mathrm{H}), 6.57(\mathrm{bs}, 1 \mathrm{H}), 3.72(\mathrm{q}, J=6.2 \mathrm{~Hz}, 2 \mathrm{H}), 2.79(\mathrm{t}, J=6.3 \mathrm{~Hz}, 2 \mathrm{H}) ;{ }^{13} \mathbf{C}$ NMR $\left(125 \mathrm{MHz}, \mathrm{CDCl}_{3}\right) \delta 165.51,149.64,140.04,131.59,128.37,128.21,128.12,123.89$, 122.99, 86.28, 82.68, 38.96, 20.34; HRMS (ESI-TOF) Calcd for $\mathrm{C}_{17} \mathrm{H}_{15} \mathrm{~N}_{2} \mathrm{O}_{3}{ }^{+}[\mathrm{M}+\mathrm{H}]^{+}$ 295.1077 , found 295.1080 .

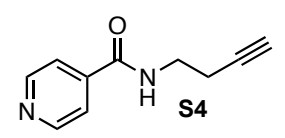

$\boldsymbol{N}$-(but-3-yn-1-yl)isonicotinamide (S4): The title compound was prepared using isonicotinoyl chloride hydrochloride $(4.27 \mathrm{~g}, 24.0 \mathrm{mmol})$ and 3-butynylamine (1.38 $\mathrm{g}, 20.0 \mathrm{mmol})$ according to the general procedure. Purification using silica gel chromatography with 2:1 hexanes:EtOAc as the eluent gave the product as a white powder $(3.48 \mathrm{~g}, 60.5 \%$ yield $) .{ }^{1} \mathbf{H}$ NMR $\left(500 \mathrm{MHz}, \mathrm{CDCl}_{3}\right) \delta 8.77-8.76(\mathrm{~m}$, $2 \mathrm{H}), 7.62-7.61(\mathrm{~m}, 2 \mathrm{H}), 6.55(\mathrm{~s}, 1 \mathrm{H}), 3.64(\mathrm{q}, J=6.2 \mathrm{~Hz}, 2 \mathrm{H}), 2.55\left(\mathrm{td}, J_{1}=6.3 \mathrm{~Hz}, J_{2}=2.6 \mathrm{~Hz}\right.$, 2H), $2.08(\mathrm{t}, J=2.6 \mathrm{~Hz}, 1 \mathrm{H}) ;{ }^{13} \mathrm{C}$ NMR $\left(125 \mathrm{MHz}, \mathrm{CDCl}_{3}\right) \delta 165.66,150.41,141.47,120.85$, 81.06, 70.31, 38.50, 19.18; HRMS (ESI-TOF) Calcd for $\mathrm{C}_{10} \mathrm{H}_{11} \mathrm{~N}_{2} \mathrm{O}^{+}[\mathrm{M}+\mathrm{H}]^{+}$175.0866, found 175.0870 .

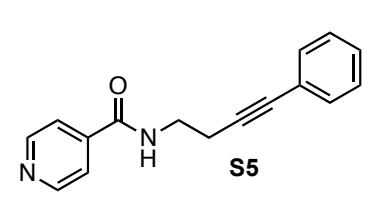

N-(4-phenylbut-3-yn-1-yl)isonicotinamide (S5): The title compound was prepared from $N$-(but-3-yn-1-yl) isonicotinamide (S4) $\quad$ (871 mg, 5.0 $\mathrm{mmol})$ and iodobenzene $(1.12 \mathrm{~g}, 5.5 \mathrm{mmol})$ according to the general procedure. Purification using silica gel chromatography with $3: 1$ hexanes:EtOAc as the eluent gave the product as a yellow solid (400 mg, 32\% yield). ${ }^{1} \mathbf{H}$ NMR $\left(500 \mathrm{MHz}, \mathrm{CDCl}_{3}\right) \delta 8.74(\mathrm{~d}, J=6.0 \mathrm{~Hz}, 2 \mathrm{H}), 7.62(\mathrm{~d}, J=6.1 \mathrm{~Hz}, 2 \mathrm{H}), 7.41-7.38(\mathrm{~m}, 2 \mathrm{H})$, 7.31-7.30 (m, 3H), $6.70(\mathrm{bs}, 1 \mathrm{H}), 3.70(\mathrm{q}, J=6.2 \mathrm{~Hz}, 2 \mathrm{H}), 2.77(\mathrm{t}, J=6.4 \mathrm{~Hz}, 2 \mathrm{H})$; ${ }^{13} \mathbf{C}$ NMR $\left(125 \mathrm{MHz}, \mathrm{CDCl}_{3}\right) \delta 165.60,150.62,141.50,131.59,128.34,128.15,123.02,120.81,86.31$, 
82.59, 38.83, 20.30; HRMS (ESI-TOF) Calcd for $\mathrm{C}_{16} \mathrm{H}_{15} \mathrm{~N}_{2} \mathrm{O}^{+}[\mathrm{M}+\mathrm{H}]^{+}$251.1179, found 251.1184 .

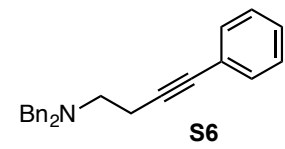

$\boldsymbol{N}, \boldsymbol{N}$-dibenzyl-4-phenylbut-3-yn-1-amine (S6): The title compound was prepared according to a literature procedure ${ }^{2}$ from 4-phenylbut-3-yn-1-yl-4-methylbenzenesulfonate ${ }^{3}$ (601 $\left.\mathrm{mg}, \quad 2.0 \mathrm{mmol}\right)$, dibenzylamine (592 mg, $3.0 \mathrm{mmol}$ ), and $\mathrm{K}_{2} \mathrm{CO}_{3}(415 \mathrm{mg}, 3.0 \mathrm{mmol})$. Purification using silica gel chromatography with 40:1 pentane: $\mathrm{Et}_{2} \mathrm{O}$ as the eluent gave the product as a colorless oil $(231 \mathrm{mg}$, $36 \%$ yield). ${ }^{1} \mathbf{H}$ NMR $\left(500 \mathrm{MHz} \mathrm{CDCl}_{3}\right) \delta 7.43-7.35(\mathrm{~m}, 5 \mathrm{H}), 7.32-7.20(\mathrm{~m}, 10 \mathrm{H}), 3.66(\mathrm{~s}, 4 \mathrm{H})$, $2.77(\mathrm{t}, J=7.2 \mathrm{~Hz}, 2 \mathrm{H}), 2.58(\mathrm{t}, J=7.2 \mathrm{~Hz}, 2 \mathrm{H}) ;{ }^{13} \mathbf{C} \mathbf{N M R}\left(125 \mathrm{MHz}, \mathrm{CDCl}_{3}\right) \delta 139.58,131.49$, $128.69,128.20,128.17,127.54,126.87,123.90,88.80,81.30,58.13,52.20,18.07$. HMRS (ESI-TOF) Calcd for $\mathrm{C}_{24} \mathrm{H}_{24} \mathrm{~N}^{+}[\mathrm{M}+\mathrm{H}]^{+} 326.1903$, found 326.1908 .

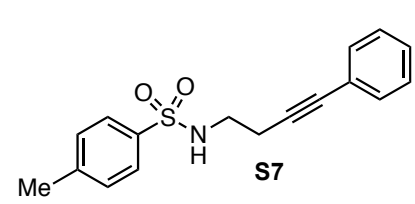

4-methyl- $N$-(4-phenylbut-3-yn-1-yl)benzenesulfon-amide (S7): The title compound was prepared from $N$-(but-3-yn-1-yl)-4methylbenzenesulfonamide ${ }^{4}(446 \mathrm{mg}, 2.0 \mathrm{mmol})$ and iodobenzene (498 mg, $2.2 \mathrm{mmol}$ ) according to the general procedure. Purification using silica gel chromatography with 2:1 hexanes:EtOAc as the eluent gave the product as a yellow powder (599 mg, 98\% yield). ${ }^{1} \mathbf{H}$ NMR (500 MHz, $\left.\mathrm{CDCl}_{3}\right) \delta 7.77(\mathrm{~d}, J=8.3 \mathrm{~Hz}, 2 \mathrm{H})$, 7.36-7.28 (m, 7H), 4.90-4.88 (m, 1H), 3.19 (q, $J=6.5 \mathrm{~Hz}, 2 \mathrm{H}), 2.57$ (t, $J=6.5 \mathrm{~Hz}, 2 \mathrm{H}), 2.41(\mathrm{~s}$, $3 \mathrm{H}) ;{ }^{13} \mathrm{C}$ NMR $\left(125 \mathrm{MHz}, \mathrm{CDCl}_{3}\right) \delta 143.53,136.99,131.60,129.75,128.24,128.12,127.07$, 122.88, 85.50, 82.83, 41.90, 21.49, 20.71; HRMS (ESI-TOF) Calcd for $\mathrm{C}_{17} \mathrm{H}_{18} \mathrm{NO}_{2} \mathrm{~S}^{+}[\mathrm{M}+\mathrm{H}]^{+}$ 300.1053 , found 300.1056 .

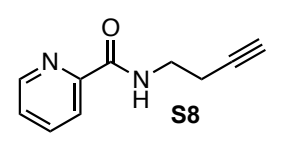

$\mathbf{N}$-(but-3-yn-1-yl)picolinamide (S8): The title compound was prepared using picolinoyl chloride hydrochloride $(1.78 \mathrm{~g}, 10.0 \mathrm{mmol})$ and 3-butynylamine $(1.2 \mathrm{~mL}, 12.0 \mathrm{mmol})$ according to the general procedure. Purification using silica gel chromatography with 3:1 hexanes:EtOAc as the eluent gave the product as an off-white solid (1.16 g, 67\% yield). ${ }^{1}$ H NMR $\left(500 \mathrm{MHz}, \mathrm{CDCl}_{3}\right) \delta 8.56\left(\mathrm{ddd}, J_{l}=4.8 \mathrm{~Hz}, J_{2}=1.8, J_{3}=\right.$ $1.0 \mathrm{~Hz}, 1 \mathrm{H}), 8.36(\mathrm{~s}, 1 \mathrm{H}), 8.20\left(\mathrm{dt}, J_{1}=7.8 \mathrm{~Hz}, J_{2}=1.1 \mathrm{~Hz}, 1 \mathrm{H}\right), 7.85\left(\mathrm{td}, J_{l}=7.7 \mathrm{~Hz}, J_{2}=1.7\right.$ $\mathrm{Hz}, 1 \mathrm{H}), 7.43\left(\mathrm{ddd}, J_{1}=7.6 \mathrm{~Hz}, J_{2}=4.7 \mathrm{~Hz}, J_{3}=1.3 \mathrm{~Hz}, 1 \mathrm{H}\right), 3.65$ (q, $\left.J=6.5 \mathrm{~Hz}, 2 \mathrm{H}\right), 2.53(\mathrm{td}$, $\left.J_{1}=6.7 \mathrm{~Hz}, J_{2}=2.7 \mathrm{~Hz}, 2 \mathrm{H}\right), 2.06(\mathrm{t}, J=2.7 \mathrm{~Hz}, 1 \mathrm{H}) ;{ }^{13} \mathbf{C}$ NMR $\left(125 \mathrm{MHz}, \mathrm{CDCl}_{3}\right) \delta 164.31$, 149.67, 148.05, 137.23, 126.12, 122.14, 81.38, 69.95, 38.04, 19.52; HRMS (ESI-TOF) Calcd for $\mathrm{C}_{10} \mathrm{H}_{11} \mathrm{~N}_{2} \mathrm{O}^{+}[\mathrm{M}+\mathrm{H}]^{+}$175.0866, found 175.0874 . 


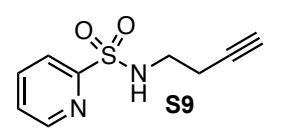

$N$-(but-3-yn-1-yl)pyridine-2-sulfonamide (S9): The title compound was prepared from pyridine-2-sulfonyl chloride ${ }^{5}(2.1 \mathrm{~g}, 12.0 \mathrm{mmol})$ and 3-butynylamine $(691 \mathrm{mg}, 10 \mathrm{mmol}$ ) according to the general procedure. Purification using silica gel chromatography with 3:1 hexanes:EtOAc as the eluent gave the product as an off-white solid (1.05 g, 49.7\% yield). ${ }^{1} \mathbf{H}$ NMR $\left(500 \mathrm{MHz}, \mathrm{CDCl}_{3}\right) \delta 8.74-8.73(\mathrm{~m}$, $1 \mathrm{H}), 8.02\left(\mathrm{dq}, J_{I}=7.8 \mathrm{~Hz}, J_{2}=1.0 \mathrm{~Hz}, 1 \mathrm{H}\right), 7.94\left(\mathrm{tdd}, J_{I}=7.8 \mathrm{~Hz}, J_{2}=1.8 \mathrm{~Hz}, J_{3}=0.8 \mathrm{~Hz}, 1 \mathrm{H}\right)$, $7.54-7.51(\mathrm{~m}, 1 \mathrm{H}), 5.69(\mathrm{t}, J=6.4 \mathrm{~Hz}, 1 \mathrm{H}), 3.26\left(\mathrm{qd}, J_{I}=6.7 \mathrm{~Hz}, J_{2}=0.8 \mathrm{~Hz}, 2 \mathrm{H}\right), 2.42$ (tdd, $J_{I}$ $\left.=6.7 \mathrm{~Hz}, J_{2}=2.7 \mathrm{~Hz}, J_{3}=0.8 \mathrm{~Hz}, 2 \mathrm{H}\right), 1.99\left(\mathrm{td}, J_{1}=2.6 \mathrm{~Hz}, J_{2}=0.8 \mathrm{~Hz}, 1 \mathrm{H}\right) ;{ }^{13} \mathbf{C} \mathbf{N M R}(125$ $\left.\mathrm{MHz}, \mathrm{CDCl}_{3}\right) \delta 157.44,150.04,138.09,126.72,122.07,80.37,70.62,42.20,20.11$; HRMS (ESI-TOF) Calcd for $\mathrm{C}_{9} \mathrm{H}_{11} \mathrm{~N}_{2} \mathrm{O}_{2} \mathrm{~S}^{+}[\mathrm{M}+\mathrm{H}]^{+}$211.0536, found 211.0537.

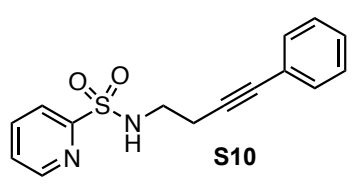

$N$-(4-phenylbut-3-yn-1-yl)pyridine-2-sulfonamide (S10): The title compound was prepared from $N$-(prop-2-yn-1-yl) pyridine-2-sulfonamide (S9) $(981 \mathrm{mg}, 5.0 \mathrm{mmol})$ and iodobenzene $(1.12 \mathrm{~g}, 5.5 \mathrm{mmol})$ according to the general procedure. Purification using silica gel chromatography with 2:1 hexanes:EtOAc as the eluent gave the product as a yellow powder $(902 \mathrm{mg}, 66 \%$ yield). ${ }^{1} \mathrm{H}$ NMR $\left(500 \mathrm{MHz}, \mathrm{CDCl}_{3}\right) \delta 8.70\left(\mathrm{dt}, J_{l}=4.7 \mathrm{~Hz}, J_{2}=1.2 \mathrm{~Hz}, 1 \mathrm{H}\right), 8.02\left(\mathrm{dt}, J_{I}=7.9 \mathrm{~Hz}, J_{2}=\right.$ $1.0 \mathrm{~Hz}, 1 \mathrm{H}), 7.90\left(\mathrm{td}, J_{l}=7.7 \mathrm{~Hz}, J_{2}=1.7 \mathrm{~Hz}, 1 \mathrm{H}\right), 7.47\left(\mathrm{dd}, J_{l}=7.7 \mathrm{~Hz}, J_{2}=4.7 \mathrm{~Hz}, 1 \mathrm{H}\right)$, 7.40-7.31 (m, 2H), 7.33-7.24 (m, 3H), 5.47 (t, $J=6.3 \mathrm{~Hz}, 1 \mathrm{H}), 3.34$ (q, $J=6.5 \mathrm{~Hz}, 2 \mathrm{H}), 2.64(\mathrm{t}$, $J=6.6 \mathrm{~Hz}, 2 \mathrm{H}) ;{ }^{13} \mathbf{C}$ NMR $\left(125 \mathrm{MHz}, \mathrm{CDCl}_{3}\right) \delta 157.55,150.10,138.03,131.63,128.23,128.08$, 126.68, 122.96, 122.03, 85.60, 82.76, 42.56, 21.08; HRMS (ESI-TOF) Calcd for $\mathrm{C}_{15} \mathrm{H}_{15} \mathrm{~N}_{2} \mathrm{O}_{2} \mathrm{~S}^{+}$ $[\mathrm{M}+\mathrm{H}]^{+} 287.0849$, found 287.0848.

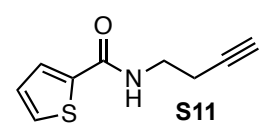

$N$-(but-3-yn-1-yl)thiophene-2-carboxamide (S11): The title compound was prepared using thiophene-2-carbonyl chloride (3.52 g, $24.0 \mathrm{mmol})$ and 3-butynylamine (1.382 $\mathrm{g}, 20.0 \mathrm{mmol})$ according to the general procedure. Purification using silica gel chromatography with 10:1 hexanes:EtOAc as the eluent gave the product as an off-white solid (2.49 g, 69\% yield). ${ }^{1} \mathbf{H}$ NMR $\left(500 \mathrm{MHz}, \mathrm{CDCl}_{3}\right) \delta 7.53\left(\mathrm{dt}, J_{l}=\right.$ $\left.3.7 \mathrm{~Hz}, J_{2}=1.0 \mathrm{~Hz}, 1 \mathrm{H}\right), 7.48\left(\mathrm{dt}, J_{I}=5.0 \mathrm{~Hz}, J_{2}=0.9 \mathrm{~Hz}, 1 \mathrm{H}\right), 7.08-7.07(\mathrm{~m}, 1 \mathrm{H}), 6.50(\mathrm{~s}, 1 \mathrm{H})$, $3.59(\mathrm{q}, J=6.3 \mathrm{~Hz}, 2 \mathrm{H}), 2.52\left(\mathrm{td}, J_{1}=6.4 \mathrm{~Hz}, J_{2}=2.5 \mathrm{~Hz}, 2 \mathrm{H}\right), 2.05(\mathrm{t}, J=2.6 \mathrm{~Hz}, 1 \mathrm{H}) ;{ }^{13} \mathbf{C}$ NMR $\left(125 \mathrm{MHz}, \mathrm{CDCl}_{3}\right) \delta 161.92,138.70,130.00,128.09,127.58,81.37,70.20,38.37,19.48$; HRMS (ESI-TOF) Calcd for $\mathrm{C}_{9} \mathrm{H}_{10} \mathrm{NOS}^{+}[\mathrm{M}+\mathrm{H}]^{+} 180.0478$, found 180.0483 .

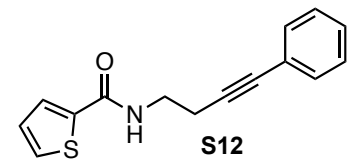

N-(4-phenylbut-3-yn-1-yl)thiophene-2-carboxamide (S12): The title compound was prepared from $N$-(but-3-yn-1-yl) thiophene-2-carboxamide (S11) (1.43 g, $8.0 \mathrm{mmol}$ ) and iodobenzene $(1.795 \mathrm{~g}, 8.8 \mathrm{mmol})$ according to the general procedure. Purification using silica gel chromatography with 2:1 hexanes:EtOAc as the eluent gave the product as a S-6 
white powder (779 mg, 38\% yield). ${ }^{1} \mathbf{H}$ NMR (500 MHz, $\left.\mathrm{CDCl}_{3}\right) \delta 7.52(\mathrm{~d}, J=4.4 \mathrm{~Hz}, 1 \mathrm{H}), 7.47$ $(\mathrm{d}, J=4.4 \mathrm{~Hz}, 1 \mathrm{H}), 7.44-7.37(\mathrm{~m}, 2 \mathrm{H}), 7.30(\mathrm{~m}, 3 \mathrm{H}), 7.08(\mathrm{t}, J=1.5 \mathrm{~Hz}, 1 \mathrm{H}), 6.35(\mathrm{bs}, 1 \mathrm{H})$, 3.67 (q, $J=6.3 \mathrm{~Hz}, 2 \mathrm{H}), 2.75(\mathrm{t}, J=6.4 \mathrm{~Hz}, 2 \mathrm{H}) ;{ }^{13} \mathbf{C}$ NMR $\left(125 \mathrm{MHz}, \mathrm{CDCl}_{3}\right) \delta 161.90,138.77$, $131.59,129.92,128.26,128.12,127.97,127.60,123.20,86.66,82.38,38.67,20.47$; HRMS (ESI-TOF) Calcd for $\mathrm{C}_{15} \mathrm{H}_{14} \mathrm{NOS}^{+}[\mathrm{M}+\mathrm{H}]^{+}$256.0791; found 256.0791.

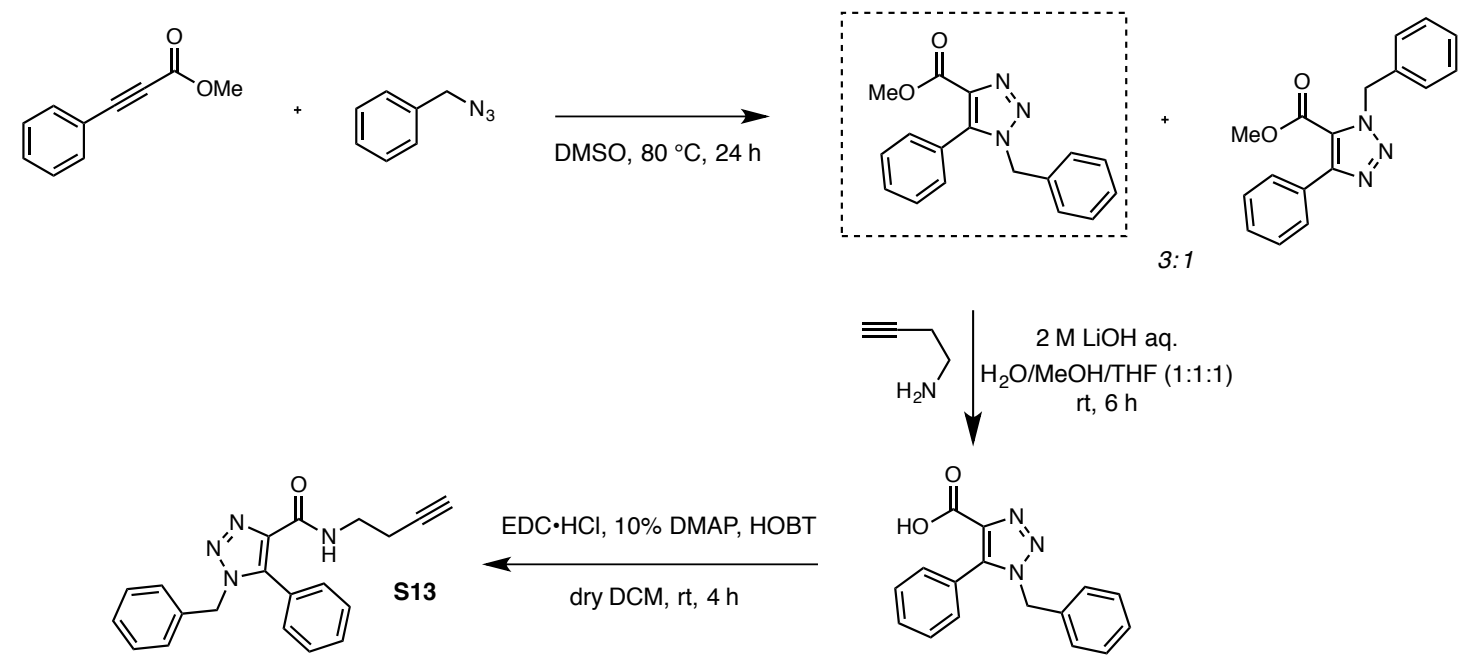

Scheme S4: General depiction of triazole formation and subsequent amide coupling.

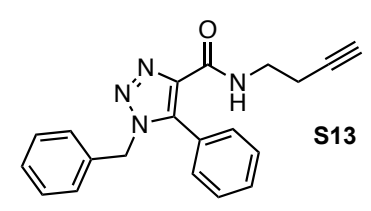

1-benzyl- $N$-(but-3-yn-1-yl)-5-phenyl-1H-1,2,3-triazole-4-carboxamide (S13): The title compound was synthesized according to a modification of a literature procedure. ${ }^{6}$ To a $250-\mathrm{mL}$ round-bottom flask equipped with a Teflon-coated magnetic stir bar were added $46 \mathrm{~mL}$ of DMSO, methyl 3-phenyl propiolate $(1.6 \mathrm{~mL}, 9.3 \mathrm{mmol})$. Next, benzyl azide $(1.8 \mathrm{~mL}, 14 \mathrm{mmol})$ was added dropwise, and the solution was left to stir at $80{ }^{\circ} \mathrm{C}$ for $24 \mathrm{~h}$. Upon completion, the reaction mixture was quenched with aqueous $\mathrm{NH}_{4} \mathrm{Cl}$ and extracted with EtOAc $(3 \times 30 \mathrm{~mL})$. The combined organic extracts were then dried with $\mathrm{Na}_{2} \mathrm{SO}_{4}$, filtered, and concentrated in vacuo. The desired triazole regiosomer was isolated from the undesired regioisomer by silica gel column chromatography with 4:1 hexanes:EtOAc as the eluent, giving the product as a white powder (872 mg, 32\% yield). The product was subjected to hydrolysis under reported conditions and resulted in formation of the acid in quantitative yield. Lastly, to a $50-\mathrm{mL}$ round-bottom flask equipped with a Teflon-coated magnetic stir bar were added the newly synthesized acid (280 mg, $1 \mathrm{mmol}), \mathrm{EDC} \cdot \mathrm{HCl}(230 \mathrm{mg}, 2 \mathrm{mmol}), \mathrm{DMAP}$ (12 $\mathrm{mg}, 0.1 \mathrm{mmol}$ ), and anhydrous HOBT (184 $\mathrm{mg}, 2 \mathrm{mmol}$ ) in $10 \mathrm{~mL}$ of anhydrous DCM followed by the dropwise addition of 3-butynyl amine $(138 \mathrm{mg}, 2 \mathrm{mmol})$. The reaction was left to stir at room temperature for $4 \mathrm{~h}$. Upon completion, the reaction mixture was quenched with aqueous $\mathrm{Na}_{2} \mathrm{CO}_{3}$ and extracted with DCM $(3 \times 15 \mathrm{~mL})$. The combined organic extracts were then dried with $\mathrm{Na}_{2} \mathrm{SO}_{4}$, filtered, and concentrated in vacuo. The crude amide product was purified by silica gel column 
chromatography with $3: 1$ hexanes:EtOAc as the eluent, giving the product as a white solid (280 $\mathrm{mg}, 85 \%$ yield). ${ }^{1} \mathbf{H}$ NMR $\left(500 \mathrm{MHz}, \mathrm{CDCl}_{3}\right) \delta 7.57(\mathrm{~s}, 1 \mathrm{H}), 7.49-7.41(\mathrm{~m}, 3 \mathrm{H}), 7.28-7.26(\mathrm{~m}$, $5 \mathrm{H}), 7.03-7.01(\mathrm{~m}, 2 \mathrm{H}), 5.43(\mathrm{~s}, 2 \mathrm{H}), 3.55(\mathrm{q}, J=6.5 \mathrm{~Hz}, 2 \mathrm{H}), 2.47\left(\mathrm{td}, J_{l}=6.6 \mathrm{~Hz}, J_{2}=2.6 \mathrm{~Hz}\right.$, 2H), $2.03(\mathrm{t}, J=2.7 \mathrm{~Hz}, 1 \mathrm{H}) ;{ }^{13} \mathbf{C}$ NMR $\left(125 \mathrm{MHz}, \mathrm{CDCl}_{3}\right) \delta 160.27,139.35,138.79,134.71$, $129.95,128.81,128.49,128.39,127.49,125.88,99.57,81.38,70.07,52.04,37.66,19.58$; HRMS (ESI-TOF) Calcd for $\mathrm{C}_{20} \mathrm{H}_{19} \mathrm{~N}_{4} \mathrm{O}^{+}[\mathrm{M}+\mathrm{H}]^{+} 331.1553$, found 331.1557 .

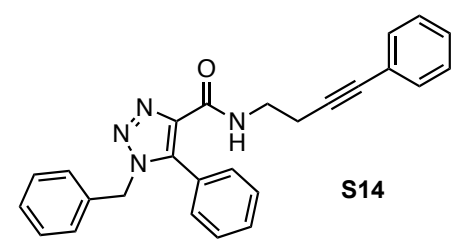

1-benzyl-5-phenyl-N-(4-phenylbut-3-yn-1-yl)-1H-1,2,3-triazole4-carboxamide (S14): The title compound was prepared from 1-benzyl- $N$-(but-3-yn-1-yl)-5-phenyl-1H-1,2,3-triazole-4carboxamide (S13) $(330 \mathrm{mg}, 1.0 \mathrm{mmol})$ and iodobenzene $(265 \mathrm{mg}$, $1.3 \mathrm{mmol}$ ) according to the general procedure. Purification using silica gel chromatography with 3:1 hexanes:EtOAc as the eluent gave the product as a yellow solid (228 mg, $69 \%$ yield). ${ }^{1} \mathbf{H}$ NMR $\left(500 \mathrm{MHz}, \mathrm{CDCl}_{3}\right) \delta 7.60(\mathrm{t}, J=6.4 \mathrm{~Hz}, 1 \mathrm{H}), 7.51-7.38$ (m, 5H), 7.30-7.26 (m, 8H), $7.02\left(\mathrm{dd}, J_{1}=6.5 \mathrm{~Hz}, J_{2}=2.8 \mathrm{~Hz}, 2 \mathrm{H}\right), 5.43(\mathrm{~s}, 2 \mathrm{H}), 3.63(\mathrm{q}, J=6.5$ $\mathrm{Hz}, 2 \mathrm{H}), 2.69$ (t, $J=6.6 \mathrm{~Hz}, 2 \mathrm{H}) ;{ }^{13} \mathbf{C}$ NMR $\left(125 \mathrm{MHz}, \mathrm{CDCl}_{3}\right) \delta 160.29,139.34,138.88$, 134.73, 131.68, 129.97, 129.93, 128.81, 128.48, 128.38, 128.19, 127.83, 127.48, 125.91, 123.38, $86.78,82.20,52.03,37.94,20.60$; HRMS (ESI-TOF) Calcd for $\mathrm{C}_{26} \mathrm{H}_{22} \mathrm{~N}_{4} \mathrm{NaO}^{+}[\mathrm{M}+\mathrm{Na}]^{+}$ 429.1686 , found 429.1688 .

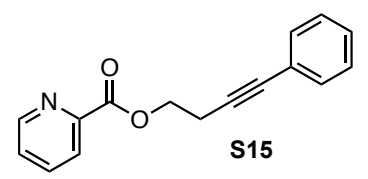

4-phenylbut-3-yn-1-yl picolinate (S15): To a 100-mL round-bottom flask equipped with a Teflon-coated magnetic stir bar were added picolinoyl chloride $(1.78 \mathrm{~g}, 10.0 \mathrm{mmol})$ and anhydrous dichloromethane $(20 \mathrm{~mL})$. After the solution was stirred for 15 minutes at $0{ }^{\circ} \mathrm{C}$ in an ice bath, 4-phenylbut-3-yn-1-ol (1.46 g, $10.0 \mathrm{mmol})$ was added slowly, followed by dropwise addition of triethylamine $(30.0 \mathrm{mmol})$. The reaction was allowed to warm to room temperature and stir for $6 \mathrm{~h}$. Upon completion, the reaction mixture was quenched with aqueous $\mathrm{Na}_{2} \mathrm{CO}_{3}$ and extracted with DCM $(3 \times 15 \mathrm{~mL})$. The combined organic extracts were then dried with $\mathrm{Na}_{2} \mathrm{SO}_{4}$, filtered, and concentrated in vacuo. The crude ester product was purified by silica gel column chromatography with 3:1 hexanes:EtOAc as the eluent, giving the product as a white powder (2.21 g, 88\% yield). ${ }^{1} \mathbf{H}$ NMR $\left(500 \mathrm{MHz}, \mathrm{CDCl}_{3}\right) \delta 8.77(\mathrm{~d}, J=4.9 \mathrm{~Hz}, 1 \mathrm{H}), 8.16(\mathrm{~d}, J=7.8 \mathrm{~Hz}$, $1 \mathrm{H}), 7.87-7.83(\mathrm{~m}, 1 \mathrm{H}), 7.48\left(\mathrm{dt}, J_{I}=7.5 \mathrm{~Hz}, J_{2}=4.8 \mathrm{~Hz}, 1 \mathrm{H}\right), 7.40(\mathrm{~d}, J=6.8 \mathrm{~Hz}, 2 \mathrm{H})$, 7.30-7.25 (m, 2H), 4.61 (t, $J=6.6 \mathrm{~Hz}, 2 \mathrm{H}), 2.96(\mathrm{t}, J=7.2 \mathrm{~Hz}, 2 \mathrm{H}) ;{ }^{13} \mathbf{C}$ NMR $(125 \mathrm{MHz}$, $\left.\mathrm{CDCl}_{3}\right) \delta 164.87,149.91,147.84,136.97,131.59,128.16,127.90,126.94,125.25,123.25,84.93$, 82.28, 63.57, 19.96; HRMS (ESI-TOF) Calcd for $\mathrm{C}_{16} \mathrm{H}_{14} \mathrm{NO}_{2}{ }^{+}[\mathrm{M}+\mathrm{H}]^{+} 252.1019$, found 252.1018 . 
Synthesis of 4-Aryl Homopropargyl Picolinamide Substrates $1 \mathbf{a}-\mathbf{1 k}, \mathbf{1 w}$, and $\mathbf{1 x}$ :

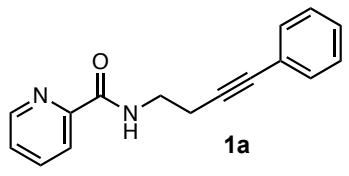

$N$-(4-phenylbut-3-yn-1-yl)picolinamide (1a): The title compound was prepared from $N$-(but-3-yn-1-yl) picolinamide (S8) $(174 \mathrm{mg}, 1.0 \mathrm{mmol})$ and iodobenzene (265 $\mathrm{mg}, 1.3 \mathrm{mmol}$ ) according to the general procedure. Purification using silica gel chromatography with $2: 1$ hexanes:EtOAc as the eluent gave the product as a yellow solid ( $240 \mathrm{mg}, 96 \%$ yield). ${ }^{1} \mathbf{H}$ NMR $\left(500 \mathrm{MHz}, \mathrm{CDCl}_{3}\right)$ $\delta 8.57(\mathrm{~d}, J=4.7 \mathrm{~Hz}, 1 \mathrm{H}), 8.42(\mathrm{bs}, 1 \mathrm{H}), 8.21(\mathrm{~d}, J=7.9 \mathrm{~Hz}, 1 \mathrm{H}), 7.85\left(\mathrm{td}, J_{I}=7.7 \mathrm{~Hz}, J_{2}=1.7\right.$ $\mathrm{Hz}, 1 \mathrm{H}), 7.44-7.42(\mathrm{~m}, 3 \mathrm{H}), 7.34-7.26(\mathrm{~m}, 3 \mathrm{H}), 3.73$ (q, $J=6.6 \mathrm{~Hz}, 2 \mathrm{H}), 2.76(\mathrm{t}, J=6.7 \mathrm{~Hz}, 2 \mathrm{H})$; ${ }^{13} \mathrm{C}$ NMR $\left(125 \mathrm{MHz}, \mathrm{CDCl}_{3}\right) \delta 164.38,149.83,148.11,137.31,131.66,128.21,127.86,126.17$, 123.46, 122.22, 86.86, 82.23, 38.35, 20.58; HRMS (ESI-TOF) Calcd for $\mathrm{C}_{16} \mathrm{H}_{15} \mathrm{~N}_{2} \mathrm{O}^{+}[\mathrm{M}+\mathrm{H}]^{+}$ 251.1179, found 251.1183.

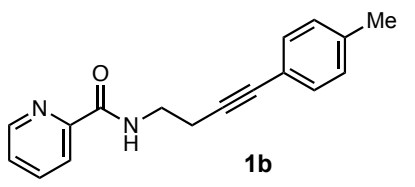

$N$-(4-(p-tolyl)but-3-yn-1-yl)picolinamide) (1b): The title compound was prepared from $N$-(but-3-yn-1-yl) picolinamide (S8) (174 mg, 1.0 $\mathrm{mmol})$ and 4-iodotoluene (240 $\mathrm{mg}, 1.1 \mathrm{mmol})$ according to the general procedure. Purification using silica gel chromatography with 2:1 hexanes:EtOAc as the eluent gave the product as a yellow powder ( $243 \mathrm{mg}, 92 \%$ yield). ${ }^{1} \mathbf{H}$ NMR $\left(500 \mathrm{MHz}, \mathrm{CDCl}_{3}\right) \delta 8.56(\mathrm{~d}, J=4.6 \mathrm{~Hz}, 1 \mathrm{H}), 8.42(\mathrm{bs}, 1 \mathrm{H}), 8.21(\mathrm{~d}, J=7.8 \mathrm{~Hz}, 1 \mathrm{H})$, $7.87-7.83(\mathrm{~m}, 1 \mathrm{H}), 7.43$ (t, $J=6.2 \mathrm{~Hz}, 1 \mathrm{H}), 7.32(\mathrm{~d}, J=7.9 \mathrm{~Hz} 2 \mathrm{H}), 7.10(\mathrm{~d}, J=7.8 \mathrm{~Hz}, 2 \mathrm{H})$, $3.72(\mathrm{q}, J=6.6 \mathrm{~Hz}, 2 \mathrm{H}), 2.74(\mathrm{t}, J=6.7 \mathrm{~Hz}, 2 \mathrm{H}), 2.34(\mathrm{~s}, 3 \mathrm{H}) ;{ }^{13} \mathbf{C} \mathbf{N M R}\left(125 \mathrm{MHz}, \mathrm{CDCl}_{3}\right) \delta$ $164.38,149.85,148.10,137.89,137.30,131.53,128.97,126.15,122.22,120.36,86.04,82.29$, 38.39, 21.41, 20.58; HRMS (ESI-TOF) Calcd for $\mathrm{C}_{17} \mathrm{H}_{17} \mathrm{~N}_{2} \mathrm{O}^{+}[\mathrm{M}+\mathrm{H}]^{+}$265.1335, found 265.1335 .

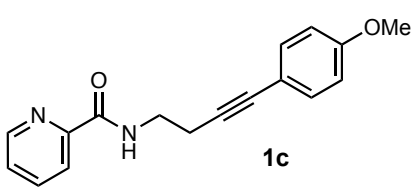

$N$-(4-(4-methoxyphenyl)but-3-yn-1-yl)picolinamide (1c): The title compound was prepared from $N$-(but-3-yn-1-yl) picolinamide (S8) (174 mg, $1.0 \mathrm{mmol})$ and 4-iodoanisole $(257 \mathrm{mg}, 1.1 \mathrm{mmol})$ according to the general procedure. Purification using silica gel chromatography with 2:1 hexanes:EtOAc as the eluent gave the product as a yellow solid (258 $\mathrm{mg}, 92 \%$ yield). ${ }^{1} \mathbf{H}$ NMR $\left(500 \mathrm{MHz}, \mathrm{CDCl}_{3}\right) \delta 8.56(\mathrm{~d}, J=4.8 \mathrm{~Hz}, 1 \mathrm{H}), 8.41(\mathrm{bs}, 1 \mathrm{H}), 8.21(\mathrm{~d}, J=7.8 \mathrm{~Hz}, 1 \mathrm{H})$, $7.85\left(\mathrm{td}, J_{1}=7.7 \mathrm{~Hz}, J_{2}=1.7 \mathrm{~Hz}, 1 \mathrm{H}\right), 7.46-7.39(\mathrm{~m}, 1 \mathrm{H}), 7.40-7.33(\mathrm{~m}, 2 \mathrm{H}), 6.86-6.79(\mathrm{~m}, 2 \mathrm{H})$, $3.80(\mathrm{~s}, 3 \mathrm{H}), 3.71(\mathrm{q}, J=6.6 \mathrm{~Hz}, 2 \mathrm{H}), 2.73(\mathrm{t}, J=6.6 \mathrm{~Hz}, 2 \mathrm{H}) ;{ }^{13} \mathbf{C}$ NMR $\left(125 \mathrm{MHz}, \mathrm{CDCl}_{3}\right) \delta$ 164.36, 159.27, 149.87, 148.10, 137.30, 133.01, 126.15, 122.22, 115.59, 113.84, 85.25, 82.00, 55.26, 38.43, 20.56; HRMS (ESI-TOF) Calcd for $\mathrm{C}_{17} \mathrm{H}_{17} \mathrm{~N}_{2} \mathrm{O}_{2}^{+}[\mathrm{M}+\mathrm{H}]^{+}$281.1285, found 281.1286 . 


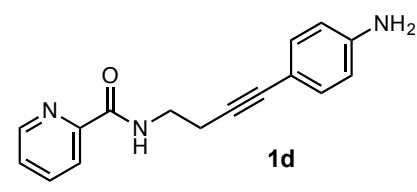

$N$-(4-(4-aminophenyl)but-3-yn-1-yl)picolinamide (1d): The title compound was prepared from $N$-(but-3-yn-1-yl) picolinamide (S8) (174 mg, $1.0 \mathrm{mmol})$ and 4-iodoaniline $(285 \mathrm{mg}, 1.3 \mathrm{mmol})$ according to the general procedure. Purification using silica gel chromatography with 1.5:1 hexanes:EtOAc as the eluent gave the product as a white powder $(241 \mathrm{mg}, 91 \%$ yield $)$. ${ }^{1} \mathbf{H}$ NMR $\left(500 \mathrm{MHz}, \mathrm{CDCl}_{3}\right) \delta 8.56(\mathrm{~d}, J=4.8 \mathrm{~Hz}, 1 \mathrm{H}), 8.41(\mathrm{bs}, 1 \mathrm{H}), 8.21(\mathrm{~d}, J=7.8 \mathrm{~Hz}, 1 \mathrm{H})$, $7.85\left(\mathrm{td}, J_{1}=7.7 \mathrm{~Hz}, J_{2}=1.7 \mathrm{~Hz}, 1 \mathrm{H}\right), 7.42\left(\mathrm{ddd}, J_{1}=7.6 \mathrm{~Hz}, J_{2}=4.8 \mathrm{~Hz}, J_{3}=1.3 \mathrm{~Hz}, 1 \mathrm{H}\right)$, $7.27-7.20(\mathrm{~m}, 2 \mathrm{H}), 6.62-6.56(\mathrm{~m}, 2 \mathrm{H}), 3.75(\mathrm{~s}, 2 \mathrm{H}), 3.70(\mathrm{q}, J=6.6 \mathrm{~Hz}, 2 \mathrm{H}), 2.72(\mathrm{t}, J=6.7 \mathrm{~Hz}$, $2 \mathrm{H}) ;{ }^{13} \mathbf{C}$ NMR $\left(125 \mathrm{MHz}, \mathrm{CDCl}_{3}\right) \delta 164.35,149.89,148.10,146.22,137.28,132.90,126.12$, $122.21,114.68,112.95,84.28,82.55,38.51,20.58$; HRMS (ESI-TOF) Calcd for $\mathrm{C}_{16} \mathrm{H}_{16} \mathrm{~N}_{3} \mathrm{O}^{+}$ $[\mathrm{M}+\mathrm{H}]^{+} 266.1288$, found 266.1288 .

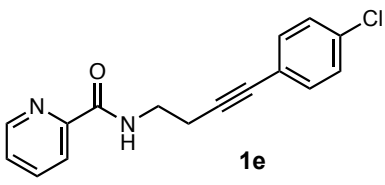

$N$-(4-(4-chlorophenyl)but-3-yn-1-yl)picolinamide (1e): The title compound was prepared from $N$-(but-3-yn-1-yl) picolinamide (S8) (174 $\mathrm{mg}, 1.0 \mathrm{mmol})$ and 1-chloro-4-iodobenzene $(262 \mathrm{mg}, 1.1 \mathrm{mmol})$ according to the general procedure. Purification using silica gel chromatography with 2:1 hexanes:EtOAc as the eluent gave the product as an off-white powder (268 mg, 94\% yield). ${ }^{1} \mathbf{H}$ NMR $\left(500 \mathrm{MHz}, \mathrm{CDCl}_{3}\right) \delta 8.56(\mathrm{~d}, J=4.5 \mathrm{~Hz}, 1 \mathrm{H}), 8.40(\mathrm{bs}, 1 \mathrm{H}), 8.21$ $(\mathrm{d}, J=7.8 \mathrm{~Hz}, 1 \mathrm{H}), 7.86\left(\mathrm{td}, J_{1}=7.7 \mathrm{~Hz}, J_{2}=1.7 \mathrm{~Hz}, 1 \mathrm{H}\right), 7.44\left(\mathrm{ddd}, J_{1}=7.6 \mathrm{~Hz}, J_{2}=4.7, J_{3}=\right.$ $1.2 \mathrm{~Hz}, 1 \mathrm{H}), 7.38-7.31(\mathrm{~m}, 2 \mathrm{H}), 7.30-7.23(\mathrm{~m}, 2 \mathrm{H}), 3.72(\mathrm{q}, J=6.6 \mathrm{~Hz}, 2 \mathrm{H}), 2.75(\mathrm{t}, J=6.7 \mathrm{~Hz}$, 2H); ${ }^{13}$ C NMR (125 MHz, $\left.\mathrm{CDCl}_{3}\right) \delta 164.39,149.79,148.11,137.35,133.84,132.89,128.53$, 126.22, 122.24, 121.95, 87.97, 81.18, 38.24, 20.58; HRMS (ESI-TOF) Calcd for $\mathrm{C}_{16} \mathrm{H}_{14} \mathrm{ClN}_{2} \mathrm{O}^{+}$ $[\mathrm{M}+\mathrm{H}]^{+} 289.0789$, found 289.0797.

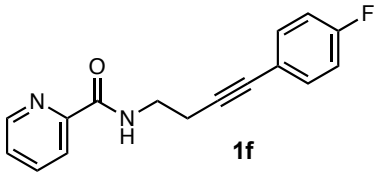

$\mathrm{N}$-(4-(4-fluorophenyl)but-3-yn-1-yl)picolinamide (1f): The title compound was prepared from $N$-(but-3-yn-1-yl) picolinamide (S8) (174 $\mathrm{mg}, 1.0 \mathrm{mmol})$ and 1-fluoro-4-iodobenzene $(289 \mathrm{mg}, 1.3 \mathrm{mmol})$ according to the general procedure. Purification using silica gel chromatography with 2:1 hexanes:EtOAc as the eluent gave the product as an off-white solid (246 mg, 92\% yield). ${ }^{1} \mathbf{H}$ NMR $\left(500 \mathrm{MHz}, \mathrm{CDCl}_{3}\right) \delta 8.56(\mathrm{~d}, J=4.8 \mathrm{~Hz}, 1 \mathrm{H}), 8.40(\mathrm{bs}, 1 \mathrm{H}), 8.21$ $(\mathrm{d}, J=7.8 \mathrm{~Hz}, 1 \mathrm{H}), 7.86\left(\mathrm{td}, J_{1}=7.7 \mathrm{~Hz}, J_{2}=1.7 \mathrm{~Hz}, 1 \mathrm{H}\right), 7.45-7.38(\mathrm{~m}, 3 \mathrm{H}), 7.03-6.94(\mathrm{~m}$, 2H), 3.72 (q, $J=6.6 \mathrm{~Hz}, 2 \mathrm{H}), 2.74(\mathrm{t}, J=6.7 \mathrm{~Hz}, 2 \mathrm{H}) ;{ }^{13} \mathbf{C} \mathbf{N M R}\left(125 \mathrm{MHz}, \mathrm{CDCl}_{3}\right) \delta 164.38$, $162.23(\mathrm{~d}, J=248.4 \mathrm{~Hz}), 149.81,148.10,137.34,133.47$ (d, $J=8.4 \mathrm{~Hz}), 126.21,122.23,119.50$, $115.44(\mathrm{~d}, J=22.0 \mathrm{~Hz}), 86.53,81.17,38.30,20.51$; HRMS (ESI-TOF) Calcd for $\mathrm{C}_{16} \mathrm{H}_{14} \mathrm{FN}_{2} \mathrm{O}^{+}$ $[\mathrm{M}+\mathrm{H}]^{+}$269.1085, found 269.1086.

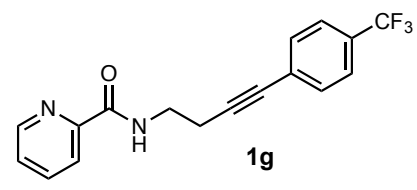

N-(4-(4-chlorophenyl)but-3-yn-1-yl)picolinamide (1g): The title compound was prepared from $N$-(but-3-yn-1-yl) picolinamide (S8) 
(174 mg, $1.0 \mathrm{mmol}$ ) and 4-iodobenzotrifluoride (354 mg, $1.3 \mathrm{mmol}$ ) according to the general procedure. Purification using silica gel chromatography with 2:1 hexanes:EtOAc as the eluent gave the product as an off-white powder $(277 \mathrm{mg}, 87 \%$ yield $) .{ }^{1} \mathbf{H}$ NMR $\left(500 \mathrm{MHz}, \mathrm{CDCl}_{3}\right) \delta$ 8.57 (d, $J=4.7 \mathrm{~Hz}, 1 \mathrm{H}), 8.41$ (bs, $1 \mathrm{H}), 8.22(\mathrm{~d}, J=7.8 \mathrm{~Hz}, 1 \mathrm{H}), 7.86\left(\mathrm{td}, J_{1}=7.7 \mathrm{~Hz}, J_{2}=1.7\right.$ $\mathrm{Hz}, 1 \mathrm{H}), 7.53(\mathrm{q}, J=7.6 \mathrm{~Hz}, 4 \mathrm{H}), 7.44\left(\mathrm{ddd}, J_{1}=7.6 \mathrm{~Hz}, J_{2}=4.8 \mathrm{~Hz}, J_{3}=1.3 \mathrm{~Hz}, 1 \mathrm{H}\right), 3.74(\mathrm{q}, J$ $=6.6 \mathrm{~Hz}, 2 \mathrm{H}), 2.78(\mathrm{t}, J=6.7 \mathrm{~Hz}, 2 \mathrm{H}) ;{ }^{13} \mathbf{C ~ N M R}\left(125 \mathrm{MHz}, \mathrm{CDCl}_{3}\right) \delta 164.43,149.73,148.12$, $137.39,131.90,129.63\left(\mathrm{q}, J_{C-F}=32.4 \mathrm{~Hz}\right), 127.29,126.28,125.15\left(\mathrm{q}, J_{C-F}=3.6 \mathrm{~Hz}\right), 123.94(\mathrm{q}$, $J_{C-F}=272.3 \mathrm{~Hz}$ ), 122.25, 89.70, 81.07, 38.15, 20.61; HRMS (ESI-TOF) Calcd for $\mathrm{C}_{17} \mathrm{H}_{14} \mathrm{~F}_{3} \mathrm{~N}_{2} \mathrm{O}^{+}[\mathrm{M}+\mathrm{H}]^{+}$319.1053, found 319.1057.

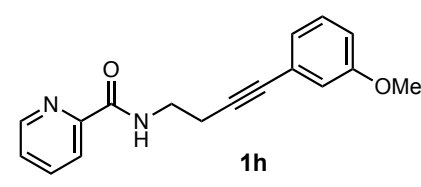

N-(4-(3-methoxyphenyl)but-3-yn-1-yl)picolinamide (1h): The title compound was prepared from $N$-(but-3-yn-1-yl) picolinamide (S8) (174 $\mathrm{mg}, 1.0 \mathrm{mmol}$ ) and 3-iodoanisole (304 $\mathrm{mg}, 1.3 \mathrm{mmol}$ ) according to the general procedure. Purification using silica gel chromatography with 2:1 hexanes:EtOAc as the eluent gave the product as a yellow oil (258 $\mathrm{mg}, 92 \%$ yield). ${ }^{1} \mathbf{H}$ NMR $\left(500 \mathrm{MHz}, \mathrm{CDCl}_{3}\right) \delta 8.56(\mathrm{~d}, J=3.4 \mathrm{~Hz}, 1 \mathrm{H}), 8.42(\mathrm{bs}, 1 \mathrm{H}), 8.21$ (d, $\left.J=7.8 \mathrm{~Hz}, 1 \mathrm{H}\right), 7.85$ $\left(\mathrm{td}, J_{1}=7.7 \mathrm{~Hz}, J_{2}=1.7 \mathrm{~Hz}, 1 \mathrm{H}\right), 7.43\left(\mathrm{ddd}, J_{1}=7.7 \mathrm{~Hz}, J_{2}=4.7 \mathrm{~Hz}, J_{3}=1.2 \mathrm{~Hz}, 1 \mathrm{H}\right), 7.20(\mathrm{t}, J$ $=7.9 \mathrm{~Hz}, 1 \mathrm{H}), 7.02(\mathrm{~d}, J=7.7 \mathrm{~Hz}, 1 \mathrm{H}), 6.97(\mathrm{~m}, 1 \mathrm{H}), 6.88-6.82(\mathrm{~m}, 1 \mathrm{H}), 3.79(\mathrm{~s}, 3 \mathrm{H}), 3.73(\mathrm{q}, J$ $=6.6 \mathrm{~Hz}, 2 \mathrm{H}), 2.75(\mathrm{t}, J=6.7 \mathrm{~Hz}, 2 \mathrm{H}) ;{ }^{13} \mathbf{C ~ N M R}\left(125 \mathrm{MHz}, \mathrm{CDCl}_{3}\right) \delta 164.38,159.27,149.83$, $148.11,137.31,129.27,126.18,124.45,124.19,122.22,116.59,114.45,86.74,82.15,55.24$, 38.32, 20.56; HRMS (ESI-TOF) Calcd for $\mathrm{C}_{17} \mathrm{H}_{17} \mathrm{~N}_{2} \mathrm{O}_{2}{ }^{+}[\mathrm{M}+\mathrm{H}]^{+}$281.1285, found 281.1288.

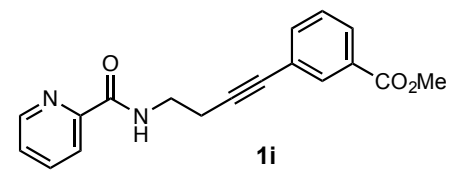

Methyl 3-(4-(picolinamido)but-1-yn-1-yl)benzoate (1i): The title compound was prepared from $N$-(but-3-yn-1-yl) picolinamide (S8) (174 $\mathrm{mg}, 1.0 \mathrm{mmol}$ ) and methyl-3- iodobenzoate $(341 \mathrm{mg}, 1.3 \mathrm{mmol})$ according to the general procedure. Purification using silica gel chromatography with 2:1 hexanes:EtOAc as the eluent gave the product as a yellow solid (286 mg, 93\% yield). ${ }^{1} \mathbf{H}$ NMR $\left(500 \mathrm{MHz}, \mathrm{CDCl}_{3}\right) \delta 8.56(\mathrm{~d}, J=3.4 \mathrm{~Hz}, 1 \mathrm{H}), 8.44(\mathrm{bs}, 1 \mathrm{H}), 8.22(\mathrm{~d}, J$ $=7.8 \mathrm{~Hz}, 1 \mathrm{H}), 8.11(\mathrm{~m}, 1 \mathrm{H}), 7.96(\mathrm{~d}, J=7.9 \mathrm{~Hz}, 1 \mathrm{H}), 7.86\left(\mathrm{td}, J_{l}=7.7 \mathrm{~Hz}, J_{2}=1.7 \mathrm{~Hz}, 1 \mathrm{H}\right)$, $7.59(\mathrm{~d}, J=7.7 \mathrm{~Hz}, 1 \mathrm{H}), 7.47-7.40(\mathrm{~m}, 1 \mathrm{H}), 7.37$ (t, $J=7.8 \mathrm{~Hz}, 1 \mathrm{H}), 3.92(\mathrm{~s}, 3 \mathrm{H}), 3.73$ (q, $J=$ $6.6 \mathrm{~Hz}, 2 \mathrm{H}), 2.77(\mathrm{t}, J=6.7 \mathrm{~Hz}, 2 \mathrm{H}) ;{ }^{13} \mathbf{C} \mathbf{N M R}\left(125 \mathrm{MHz}, \mathrm{CDCl}_{3}\right) \delta 166.43,164.40,149.78$, $148.16,137.32,135.80,132.83,130.32,128.87,128.34,126.21,123.90,122.21,87.98,81.34$, 52.21, 38.20, 20.56; HRMS (ESI-TOF) Calcd for $\mathrm{C}_{18} \mathrm{H}_{17} \mathrm{~N}_{2} \mathrm{O}_{3}{ }^{+}[\mathrm{M}+\mathrm{H}]^{+}$309.1234, found 309.1234 .

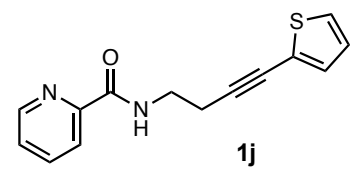

$\mathbf{N}$-(4-(thiophen-2-yl)but-3-yn-1-yl)picolinamide (1j): The title compound was prepared from $N$-(but-3-yn-1-yl) picolinamide (S8) (174 mg, $1.0 \mathrm{mmol}$ ) and 2-iodothiophene $(273 \mathrm{mg}, 1.3 \mathrm{mmol})$ according to the general 
procedure. Purification using silica gel chromatography with 2:1 hexanes:EtOAc as the eluent gave the product as a brown powder $\left(228 \mathrm{mg}, 89 \%\right.$ yield). ${ }^{1} \mathbf{H}$ NMR $\left(500 \mathrm{MHz}, \mathrm{CDCl}_{3}\right) \delta 8.56$ $(\mathrm{m}, 1 \mathrm{H}), 8.39(\mathrm{bs}, 1 \mathrm{H}), 8.20(\mathrm{~d}, J=7.8 \mathrm{~Hz}, 1 \mathrm{H}), 7.85\left(\mathrm{td}, J_{1}=7.7 \mathrm{~Hz}, J_{2}=1.7 \mathrm{~Hz}, 1 \mathrm{H}\right)$, 7.44-7.42 (m, 1H), 7.22-7.14 (m, 2H), 6.97-6.92 (m, 1H), 3.73 (q, $J=6.6 \mathrm{~Hz}, 2 \mathrm{H}), 2.78$ (t, $J=$ $6.7 \mathrm{~Hz}, 2 \mathrm{H}) ;{ }^{13} \mathbf{C}$ NMR $\left(125 \mathrm{MHz}, \mathrm{CDCl}_{3}\right) \delta 164.40,149.76,148.11,137.30,131.50,126.78$, 126.36, 126.18, 123.52, 122.20, 90.96, 75.33, 38.20, 20.84; HRMS (ESI-TOF) Calcd for $\mathrm{C}_{14} \mathrm{H}_{13} \mathrm{~N}_{2} \mathrm{OS}^{+}[\mathrm{M}+\mathrm{H}]^{+}$257.0743, found 257.0751.

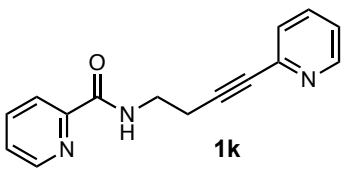

N-(4-(pyridin-2-yl)but-3-yn-1-yl)picolinamide (1k): The title compound was prepared from $N$-(but-3-yn-1-yl) picolinamide (S8) (174 mg, 1.0 mmol) and 2-iodopyridine (267 $\mathrm{mg}, 1.3 \mathrm{mmol}$ ) according to the general procedure. Purification using silica gel chromatography with 1:1 hexanes:EtOAc as the eluent gave the product as an off-white powder $\left(218 \mathrm{mg}, 87 \%\right.$ yield). ${ }^{1} \mathbf{H}$ NMR $\left(500 \mathrm{MHz}, \mathrm{CDCl}_{3}\right) \delta 8.58-8.52(\mathrm{~m}, 2 \mathrm{H}), 8.42(\mathrm{bs}, 1 \mathrm{H}), 8.20(\mathrm{~d}, J=7.9 \mathrm{~Hz}, 1 \mathrm{H}), 7.85(\mathrm{td}$, $\left.J_{1}=7.7 \mathrm{~Hz}, J_{2}=1.7 \mathrm{~Hz}, 1 \mathrm{H}\right), 7.63\left(\mathrm{td}, J_{1}=7.8 \mathrm{~Hz}, J_{2}=1.8 \mathrm{~Hz}, 1 \mathrm{H}\right), 7.50-7.38(\mathrm{~m}, 2 \mathrm{H})$, 7.24-7.17 (m, 1H), $3.76(\mathrm{q}, J=6.6 \mathrm{~Hz}, 2 \mathrm{H}), 2.81(\mathrm{t}, J=6.7 \mathrm{~Hz}, 2 \mathrm{H}) ;{ }^{13} \mathbf{C}$ NMR $(125 \mathrm{MHz}$, $\left.\mathrm{CDCl}_{3}\right) \delta 164.47,149.84,149.73,148.10,143.47,137.29,136.06,127.03,126.19,122.57$, 122.20, 87.55, 81.69, 38.14, 20.52; HRMS (ESI-TOF) Calcd for $\mathrm{C}_{15} \mathrm{H}_{14} \mathrm{~N}_{3} \mathrm{O}^{+}[\mathrm{M}+\mathrm{H}]^{+}$252.1131, found 252.1132 .

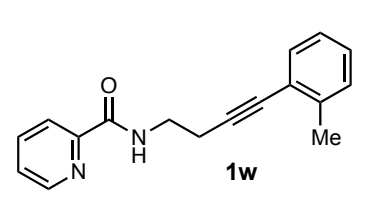

N-(3-phenylprop-2-yn-1-yl)picolinamide (1w): The title compound was prepared from $N$-(but-3-yn-1-yl) picolinamide (S8) $(87 \mathrm{mg}, 0.5$ $\mathrm{mmol}$ ) and 2-iodotoluene (109 $\mathrm{mg}, 0.5 \mathrm{mmol})$ according to the general procedure. Purification using silica gel chromatography with 2:1 hexanes:EtOAc as the eluent gave the product as a brown oil (106 mg, 80\% yield). ${ }^{1} \mathbf{H}$ NMR $\left(500 \mathrm{MHz}, \mathrm{CDCl}_{3}\right) \delta 8.64-8.48(\mathrm{~m}, 1 \mathrm{H}), 8.45(\mathrm{bs}, 1 \mathrm{H}), 8.21(\mathrm{dt}, J=7.8,1.1 \mathrm{~Hz}, 1 \mathrm{H}), 7.85(\mathrm{td}, J$ $=7.7,1.6 \mathrm{~Hz}, 1 \mathrm{H}), 7.51-7.35(\mathrm{~m}, 2 \mathrm{H}), 7.23-7.15(\mathrm{~m}, 2 \mathrm{H}), 7.13-7.10(\mathrm{~m}, 1 \mathrm{H}), 3.74(\mathrm{q}, J=6.5$ $\mathrm{Hz}, 2 \mathrm{H}), 2.80(\mathrm{t}, J=6.6 \mathrm{~Hz}, 2 \mathrm{H}), 2.43(\mathrm{~s}, 3 \mathrm{H}) ;{ }^{13} \mathbf{C}$ NMR $\left(125 \mathrm{MHz}, \mathrm{CDCl}_{3}\right) \delta 164.35,149.80$, 148.07, 140.11, 137.30, 131.93, 129.31, 127.85, 126.16, 125.43, 123.20, 122.18, 90.74, 81.12, 38.43, 20.71, 20.68; HRMS (ESI-TOF) Calcd for $\mathrm{C}_{17} \mathrm{H}_{17} \mathrm{~N}_{2} \mathrm{O}^{+}[\mathrm{M}+\mathrm{H}]^{+}$265.1335, found 265.1330 .

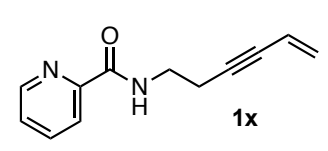

$N$-(hex-5-en-3-yn-1-yl)picolinamide (1x): The title compound was prepared from $N$-(but-3-yn-1-yl) picolinamide (S8) $(348 \mathrm{mg}, 2.0 \mathrm{mmol}$ ), bromoethene $(2.57 \mathrm{~g}, 24 \mathrm{mmol})$, triethylamine $(0.279 \mathrm{~mL}, 2 \mathrm{mmol})$, and DMF $(0.155 \mathrm{~mL}, 2 \mathrm{mmol})$ under conditions otherwise identical to those described in the general procedure. ${ }^{7}$ Purification using silica gel chromatography with $3: 1$ hexanes:EtOAc as the eluent gave the product as a pale yellow solid $(283 \mathrm{mg}, 71 \%$ yield $) .{ }^{1} \mathbf{H} \mathbf{N M R}\left(500 \mathrm{MHz}, \mathrm{CDCl}_{3}\right) \delta 8.56$ 
(ddd, $J=4.7,1.7,0.9 \mathrm{~Hz}, 1 \mathrm{H}), 8.34$ (bs, $1 \mathrm{H}), 8.20$ (dt, $J=7.8,1.1 \mathrm{~Hz}, 1 \mathrm{H}), 7.85$ (td, $J=7.7,1.7$ $\mathrm{Hz}, 1 \mathrm{H}), 7.43$ (ddd, $J=7.6,4.8,1.2 \mathrm{~Hz}, 1 \mathrm{H}), 5.84-5.75(\mathrm{~m}, 1 \mathrm{H}), 5.61(\mathrm{dd}, J=17.6,2.2 \mathrm{~Hz}, 1 \mathrm{H})$, $5.43(\mathrm{dd}, J=11.1,2.2 \mathrm{~Hz}, 1 \mathrm{H}), 3.65(\mathrm{q}, J=6.6 \mathrm{~Hz}, 2 \mathrm{H}), 2.65(\mathrm{td}, J=6.8,2.1 \mathrm{~Hz}, 2 \mathrm{H}) ;{ }^{13} \mathbf{C}$ NMR $\left(125 \mathrm{MHz}, \mathrm{CDCl}_{3}\right) \delta 164.35,149.80,148.09,137.30,126.41,126.16,122.21,117.23$, 87.60, 80.86, 38.29, 20.47; HRMS (ESI-TOF) Calcd for $\mathrm{C}_{12} \mathrm{H}_{13} \mathrm{~N}_{2} \mathrm{O}^{+}[\mathrm{M}+\mathrm{H}]^{+}$201.1022, found 201.1024 .

\section{Synthesis of Branched Homopropargyl Picolinamide Substrates $\mathbf{1 l}$ and $\mathbf{1 m}^{8}$}

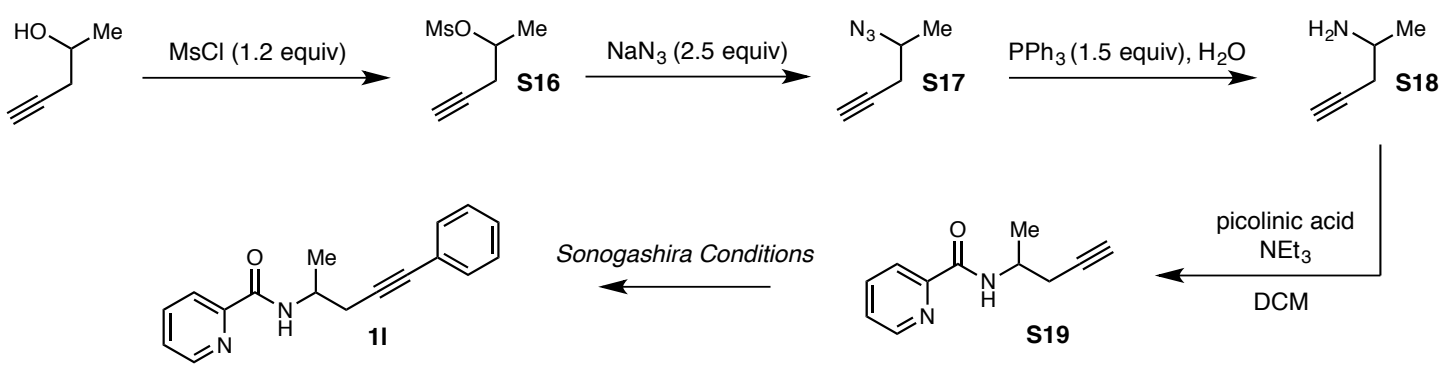

Scheme S5: Synthesis of $N$-(5-phenylpent-4-yn-2-yl)picolinamide (1I).

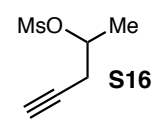

pent-4-yn-2-yl methanesulfonate (S16): To an oven-dried, nitrogen-filled 100-mL round-bottom flask equipped with a Teflon-coated magnetic stir bar were added pent-4-yn-2-ol (1.68 g, $20.0 \mathrm{mmol})$, triethylamine (2.43 g, $24.0 \mathrm{mmol})$, and anhydrous diethyl ether $(20 \mathrm{~mL})$. The reaction flask was cooled to $0{ }^{\circ} \mathrm{C}$ in an ice bath, and methanesulfonyl chloride $(2.75 \mathrm{~g}, 24.0 \mathrm{mmol})$ was added dropwise. The reaction was allowed to warm to room temperature and stir for $3 \mathrm{~h}$. Upon completion, the reaction mixture was poured carefully into a separatory funnel containing brine and extracted with $\mathrm{Et}_{2} \mathrm{O}(3 \times 15 \mathrm{~mL})$. The combined organic extracts were then dried with $\mathrm{Na}_{2} \mathrm{SO}_{4}$, filtered, and concentrated in vacuo. The crude mesylate product was carried on to the next step without purification (92\% yield).

$\mathrm{N}_{3} Y^{\mathrm{Me}}$ 4-azidopent-1-yne (S17): Anhydrous DMF $(20 \mathrm{~mL})$ was added to a nitrogen filled s17 100-mL round-bottom flask containing a Teflon-coated magnetic stir bar and the crude S16. $\mathrm{NaN}_{3}(3.90 \mathrm{~g}, 60.0 \mathrm{mmol})$ was added, and the reaction was heated to $70{ }^{\circ} \mathrm{C}$ and left to stir for $3 \mathrm{~h}$. Upon completion, the reaction was allowed to cool to room temperature, and the mixture was poured carefully into a separatory funnel containing brine. The mixture was extracted with $\mathrm{Et}_{2} \mathrm{O}(3 \times 15 \mathrm{~mL})$. The combined organic extracts were then dried with $\mathrm{Na}_{2} \mathrm{SO}_{4}$, filtered, and concentrated in vacuo. The newly synthesized crude azide product was stored under nitrogen atmosphere and then carried onto the next step without additional purification $(65 \%$ yield). 
$\mathrm{H}_{2} \mathrm{~N} Y \mathrm{Me}$ pent-4-yn-2-amine (S18): Crude S17 was dissolved in anhydrous diethyl ether (20 $\mathrm{mL})$, and the contents were cooled to $0{ }^{\circ} \mathrm{C}$. The vessel was charged with $\mathrm{PPh}_{3}(4.72 \mathrm{~g}$, $18.0 \mathrm{mmol})$ and left to stir at $0^{\circ} \mathrm{C}$. After $3 \mathrm{~h}, \mathrm{H}_{2} \mathrm{O}(1 \mathrm{~mL})$ was added and the reaction was stirred and allowed to warm to room temperature overnight. The following morning, the reaction mixture was poured carefully into a separatory funnel containing $10 \% \mathrm{HCl}$, and the resulting mixture was extracted with $\mathrm{Et}_{2} \mathrm{O}(3 \times 15 \mathrm{~mL})$. The combined organic extracts were discarded. The aqueous layer was treated with $6 \mathrm{M}$ aqueous $\mathrm{NaOH}$ solution until the solution reached a $\mathrm{pH}$ of 10 . The crude amine was extracted with diethyl ether $(5 \times 15 \mathrm{~mL})$, and the combined organic extracts were dried with $\mathrm{Na}_{2} \mathrm{SO}_{4}$, and carefully concentrated in vacuo. (The product is a low-boiling, so care should be taken in removing solvent under vacuum.) The crude product was carried on to the next step without further purification ( $778 \mathrm{mg}, 78 \%$ yield).

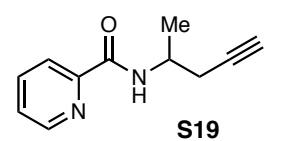

N-(pent-4-yn-2-yl)picolinamide (S19): To a 100-mL round-bottom flask equipped with a Teflon-coated magnetic stir bar were added the crude S18 (778 $\mathrm{mg}, 9.36 \mathrm{mmol})$, picolinic acid (1.38 g, $11.23 \mathrm{mmol})$, EDC $\cdot \mathrm{HCl}(2.15 \mathrm{~g}, 11.23$ mmol), DMAP (114 mg, $0.94 \mathrm{mmol})$, anhydrous HOBT (1.72 g, $11.23 \mathrm{mmol})$, and anhydrous DCM $(20 \mathrm{~mL})$. The reaction was left to stir at room temperature for $8 \mathrm{~h}$. Upon completion, the reaction mixture was quenched with aqueous $\mathrm{Na}_{2} \mathrm{CO}_{3}$ and extracted with DCM $(3 \times 15 \mathrm{~mL})$. The combined organic extracts were washed with water followed by brine, dried with $\mathrm{Na}_{2} \mathrm{SO}_{4}$, filtered, and concentrated in vacuo. The crude amide product was purified by silica gel column chromatography with 2:1 hexanes:EtOAc as the eluent, giving the product as a white solid (702 mg, 40\% yield).

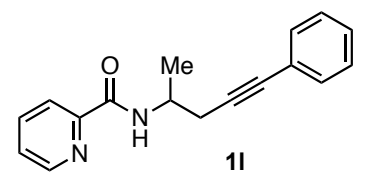

$N$-(5-phenylpent-4-yn-2-yl)picolinamide (11): To a flame-dried 50-mL round-bottom flask equipped with a Teflon-coated magnetic stir bar were added $\mathrm{Pd}\left(\mathrm{PPh}_{3}\right)_{4}(86 \mathrm{mg}, 2 \mathrm{~mol} \%$ ), CuI (35 mg, $5 \mathrm{~mol} \%$ ), and S19 (702 $\mathrm{mg}, 3.73 \mathrm{mmol})$, and anhydrous diethyl ether $(10 \mathrm{~mL})$. After the addition of solvent, the solution was stirred for $10 \mathrm{~min}$ at room temperature. 4-Iodobenzne $(990 \mathrm{mg}, 4.85$ mmol) was added slowly. Diethylamine $(545 \mathrm{mg}, 7.46 \mathrm{mmol})$ was added dropwise, and the reaction was allowed to stir at $35{ }^{\circ} \mathrm{C}$ for $3 \mathrm{~h}$. After this period of time, the reaction mixture was poured carefully into a separatory funnel containing brine. This biphasic solution was extracted with $\mathrm{Et}_{2} \mathrm{O}(3 \times 15 \mathrm{~mL})$. The organic extracts were then dried with $\mathrm{Na}_{2} \mathrm{SO}_{4}$, filtered, and concentrated in vacuo. Purification using silica gel chromatography with 3:1 hexanes:EtOAc as the eluent gave the product as a colorless oil $\left(768 \mathrm{mg}, 82 \%\right.$ yield). ${ }^{1} \mathbf{H}$ NMR $\left(500 \mathrm{MHz}, \mathrm{CDCl}_{3}\right)$ $\delta 8.56(\mathrm{~d}, J=4.8 \mathrm{~Hz}, 1 \mathrm{H}), 8.24(\mathrm{~s}, 1 \mathrm{H}), 8.21(\mathrm{~d}, J=7.8 \mathrm{~Hz}, 1 \mathrm{H}), 7.85\left(\mathrm{td}, J_{1}=7.7 \mathrm{~Hz}, \mathrm{~J}_{2}=1.6\right.$ $\mathrm{Hz}, 1 \mathrm{H}), 7.47-7.39(\mathrm{~m}, 3 \mathrm{H}), 7.34-7.24(\mathrm{~m}, 3 \mathrm{H}), 4.45\left(\mathrm{dtd}, J_{1}=8.7 \mathrm{~Hz}, J_{2}=6.5, J_{3}=4.7 \mathrm{~Hz}\right.$, 
1H), 2.82-2.70 (m, 2H), 1.45 (s, 3H); ${ }^{13} \mathbf{C}$ NMR (125 MHz, $\left.\mathrm{CDCl}_{3}\right) \delta 163.59,149.91,148.05$, $137.28,131.65,128.19,127.81,126.10,123.55,122.19,85.89,83.06,43.95,26.95,19.84$; HRMS (ESI-TOF) Calcd for $\mathrm{C}_{17} \mathrm{H}_{17} \mathrm{~N}_{2} \mathrm{O}^{+}[\mathrm{M}+\mathrm{H}]^{+} 265.1335$, found 265.1339 .

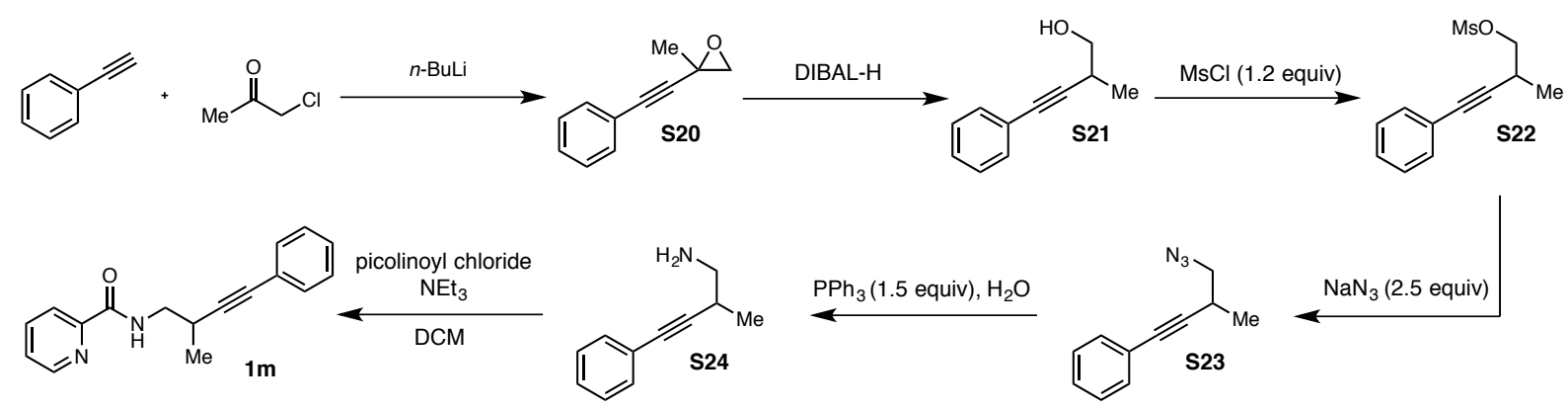

Scheme S6: Synthesis of N-(2-methyl-4-phenylbut-3-yn-1-yl)picolinamide (1m).

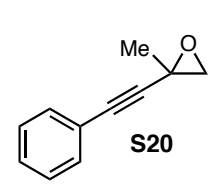

2-methyl-2-(phenylethynyl)oxirane (S20): ${ }^{9}$ To an oven-dried, $100-\mathrm{mL}$ round-bottom flask equipped with a Teflon-coated magnetic stir bar and under a nitrogen atmosphere were added phenyl acetylene $(510 \mathrm{mg}, 5.0 \mathrm{mmol})$ and anhydrous THF $(15 \mathrm{~mL})$. The reaction vessel was cooled to $-30{ }^{\circ} \mathrm{C}$, and, $n$-butyl lithium (3.4 mL, $5.5 \mathrm{mmol}, 1.6 \mathrm{M}$ in hexanes) solution was added dropwise over $30 \mathrm{~min}$. The flask was cooled to $-78{ }^{\circ} \mathrm{C}$. After $5 \mathrm{~min}$ of stirring at $-78{ }^{\circ} \mathrm{C}$, chloroacetone $(475 \mathrm{mg}, 5.0 \mathrm{mmol})$ was added dropwise over $10 \mathrm{~min}$, and the reaction vessel was allowed to warm to room temperature for $24 \mathrm{~h}$. (After approximately $1 \mathrm{~h}$, the yellow solution became a wine red color). The solution was quenched with saturated $\mathrm{NH}_{4} \mathrm{Cl}$ solution $(10 \mathrm{~mL})$ and extracted with $\mathrm{Et}_{2} \mathrm{O}(3 \times$ $20 \mathrm{~mL}$ ). The combined organic extracts were dried with $\mathrm{Na}_{2} \mathrm{SO}_{4}$, filtered, and concentrated in vacuo. The crude epoxide product was carried on to the next step without purification (78\% yield).

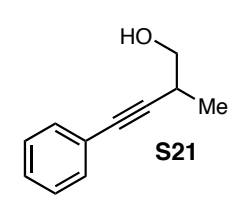

2-methyl-4-phenylbut-3-yn-1-ol (S21): To an oven-dried, 50-mL round-bottom flask equipped with a Teflon-coated magnetic stir bar and under a nitrogen atmosphere were added $\mathbf{S 2 0}(626 \mathrm{mg}, 3.9 \mathrm{mmol})$ and anhydrous THF $(8 \mathrm{~mL})$. The solution was stirred at $-20{ }^{\circ} \mathrm{C}$ for $15 \mathrm{~min}$. A solution of DIBAL-H $(5.1 \mathrm{~mL}, 5.07$ mmol, 1.3 equiv, $1.0 \mathrm{M}$ in hexanes) was added dropwise, and the reaction was allowed to warm to room temperature. Reaction progress was monitored by TLC, and after $2 \mathrm{~h}$, the reaction was observed to have proceeded to completion. The reaction was quenched with saturated $\mathrm{NH}_{4} \mathrm{Cl}$ solution $(10 \mathrm{~mL})$ and extracted with $\mathrm{Et}_{2} \mathrm{O}(3 \times 20 \mathrm{~mL})$. The combined organic extracts were dried with $\mathrm{Na}_{2} \mathrm{SO}_{4}$, filtered, and concentrated in vacuo. The crude branched product (2-methyl-4-phenylbut-3-yn-1-ol) was carried on to the next step without purification (601 mg, $97 \%$ yield). 


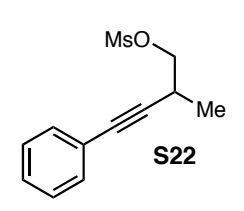

2-methyl-4-phenylbut-3-yn-1-yl methanesulfonate (S22): ${ }^{8}$ To an oven-dried, $100-\mathrm{mL}$ round-bottom flask equipped with a Teflon-coated magnetic stir bar and under a nitrogen atmosphere were added S21 (601 $\mathrm{mg}, 3.8 \mathrm{mmol})$, triethylamine

(1.15 g, $11.4 \mathrm{mmol})$, and anhydrous diethyl ether $(20 \mathrm{~mL})$. The solution was cooled to $0{ }^{\circ} \mathrm{C}$ in an ice bath, and methanesulfonyl chloride (563 mg, $4.94 \mathrm{mmol}$ ) was added dropwise. The reaction mixture was allowed to warm to room temperature and stir for $3 \mathrm{~h}$. After this time, the reaction mixture was poured carefully into a separatory funnel containing brine (20 $\mathrm{mL})$ and extracted with $\mathrm{Et}_{2} \mathrm{O}(3 \times 15 \mathrm{~mL})$. The combined organic extracts were dried with $\mathrm{Na}_{2} \mathrm{SO}_{4}$, filtered, and concentrated in vacuo. The crude mesylate product was carried on to the next step without additional purification ( $88 \%$ yield).

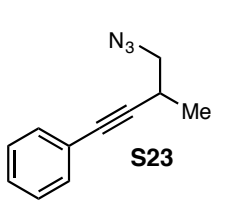

(4-azido-3-methylbut-1-yn-1-yl)benzene (S23): ${ }^{8}$ To a $100-\mathrm{mL}$ round-bottom flask containing a Teflon-coated magnetic stir bar and under a nitrogen atmosphere were added crude $\mathbf{S 2 2}$, anhydrous DMF $(20 \mathrm{~mL})$, and $\mathrm{NaN}_{3}(618 \mathrm{mg}$, $9.5 \mathrm{mmol})$. The reaction mixture was heated to $70{ }^{\circ} \mathrm{C}$ and allowed stir for $3 \mathrm{~h}$. After this time, the reaction mixture was allowed to cool to room temperature, poured carefully into a separatory funnel containing brine $(20 \mathrm{~mL})$, and extracted with $\mathrm{Et}_{2} \mathrm{O}(3 \times 15 \mathrm{~mL})$. The combined organic extracts were dried with $\mathrm{Na}_{2} \mathrm{SO}_{4}$, filtered, and concentrated in vacuo. The crude azide product was stored under nitrogen and carried on without further purification $(62 \%$ yield).

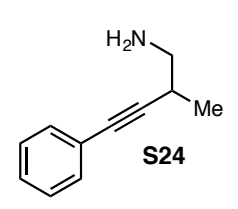

2-methyl-4-phenylbut-3-yn-1-amine (S24): ${ }^{8}$ To a 100-mL round-bottom flask equipped with a Teflon-coated magnetic stir bar were added crude $\mathbf{S 2 3}$ and anhydrous diethyl ether $(20 \mathrm{~mL})$. The reaction mixture was cooled to $0{ }^{\circ} \mathrm{C}$, and the vessel was charged with $\mathrm{PPh}_{3}(815 \mathrm{mg}, 3.1 \mathrm{mmol})$ and left to stir at $0{ }^{\circ} \mathrm{C}$. After $3 \mathrm{~h}, \mathrm{H}_{2} \mathrm{O}(1 \mathrm{~mL})$ was added, and the reaction mixture was allowed to warm to room temperature and stir overnight. The following morning, the reaction mixture was poured carefully into a separatory funnel containing $10 \% \mathrm{HCl}(20 \mathrm{~mL})$ and extracted with $\mathrm{Et}_{2} \mathrm{O}(3 \times 15$ $\mathrm{mL})$. The organic extracts were discarded. The aqueous layer was treated with $6 \mathrm{~N} \mathrm{NaOH}$ solution until it reached a $\mathrm{pH}$ of 10 . The crude amine was extracted with diethyl ether $(5 \times 15$ $\mathrm{mL}$ ), dried with $\mathrm{Na}_{2} \mathrm{SO}_{4}$, and concentrated in vacuo. The crude product was carried on to the next step without further purification (138 mg, $42 \%$ yield).

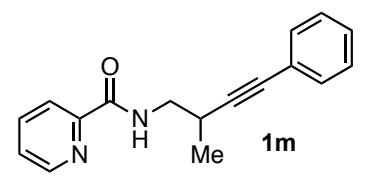

N-(2-methyl-4-phenylbut-3-yn-1-yl)picolinamide (1m): To a 100-mL round-bottom flask equipped with a Teflon-coated magnetic stir bar, were 
added picolinyl chloride hydrochloride $(214 \mathrm{mg}, 1.2 \mathrm{mmol})$ and anhydrous dichloromethane (10 $\mathrm{mL}$ ). The solution was stirred for $15 \mathrm{~min}$ at $0{ }^{\circ} \mathrm{C}$ in an ice bath, and crude $\mathbf{S 2 4}$ (138 $\mathrm{mg}, 0.87$ $\mathrm{mmol}$ ) was added dropwise, followed by dropwise addition of triethylamine (242 $\mathrm{mg}, 2.4 \mathrm{mmol})$. The reaction was allowed to warm to room temperature and stir for $4 \mathrm{~h}$. After this time, the reaction mixture was quenched with aqueous $\mathrm{Na}_{2} \mathrm{CO}_{3}(10 \mathrm{~mL})$ and extracted with $\mathrm{DCM}(3 \times 15$ $\mathrm{mL}$ ). The combined organic extracts were dried with $\mathrm{Na}_{2} \mathrm{SO}_{4}$, filtered, and concentrated in vacuo. The crude amide product was purified by silica gel column chromatography with $3: 1$ hexanes:EtOAc as the eluent, giving the product as a colorless oil ( $82 \mathrm{mg}, 64 \%$ yield). ${ }^{\mathbf{1}} \mathbf{H}$ NMR $\left(500 \mathrm{MHz}, \mathrm{CDCl}_{3}\right) \delta 8.56(\mathrm{~d}, J=4.1 \mathrm{~Hz}, 1 \mathrm{H}), 8.47(\mathrm{~s}, 1 \mathrm{H}), 8.21(\mathrm{~d}, J=7.8 \mathrm{~Hz}, 1 \mathrm{H}), 7.84\left(\mathrm{td}, J_{1}\right.$ $\left.=7.7 \mathrm{~Hz}, J_{2}=1.7 \mathrm{~Hz}, 1 \mathrm{H}\right), 7.48-7.39(\mathrm{~m}, 3 \mathrm{H}), 7.30-7.27(\mathrm{~m}, 3 \mathrm{H}), 3.73\left(\mathrm{ddd}, J_{1}=13.0 \mathrm{~Hz}, J_{2}=\right.$ 7.0, $\left.J_{3}=5.9 \mathrm{~Hz}, 1 \mathrm{H}\right), 3.50\left(\mathrm{ddd}, J_{1}=13.2 \mathrm{~Hz}, J_{2}=7.7 \mathrm{~Hz}, J_{3}=5.7 \mathrm{~Hz}, 1 \mathrm{H}\right), 3.08-2.97(\mathrm{~m}, 1 \mathrm{H})$, $1.33(\mathrm{~d}, J=7.0 \mathrm{~Hz}, 3 \mathrm{H}) ;{ }^{13} \mathrm{C}$ NMR $\left(125 \mathrm{MHz}, \mathrm{CDCl}_{3}\right) \delta 164.37,149.85,148.10,137.26,131.66$, 128.16, 127.81, 126.11, 123.42, 122.22, 91.55, 82.17, 44.54, 27.48, 18.46; HRMS (ESI-TOF) Calcd for $\mathrm{C}_{17} \mathrm{H}_{17} \mathrm{~N}_{2} \mathrm{O}^{+}[\mathrm{M}+\mathrm{H}]^{+}$265.1335, found 265.1344.

Synthesis of Alkynyl Picolinamides with Different Chain Lengths (1n, 1o, and 1t): ${ }^{8}$

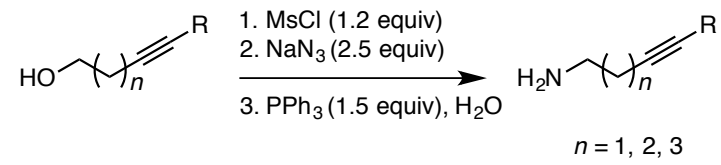

Scheme S7: General depiction of alkynyl amine synthesis.

General Procedure for Synthesis of Mesylates: To an oven-dried, 100-mL round-bottom flask equipped with a Teflon-coated magnetic stir bar and under a nitrogen atmosphere were added the appropriate alkynyl alcohol (5.0 mmol, 1 equiv), triethylamine (15 mmol, 3 equiv), and anhydrous diethyl ether $(8 \mathrm{~mL})$. The reaction mixture was cooled to $0{ }^{\circ} \mathrm{C}$, and methanesulfonyl chloride (6 mmol, 1.2 equiv) was added dropwise. The reaction was allowed to warm to room temperature for $3 \mathrm{~h}$. After this time, the reaction mixture was poured carefully into a separatory funnel containing brine $(10 \mathrm{~mL})$ and extracted with $\mathrm{Et}_{2} \mathrm{O}(3 \times 15 \mathrm{~mL})$. The combined organic extracts were dried with $\mathrm{Na}_{2} \mathrm{SO}_{4}$, filtered, and concentrated in vacuo. The crude mesylate product was carried on to the next step without purification (quantitative yield).

General Procedure for Azide Displacement: To an oven-dried 50-mL round-bottom flask containing a Teflon-coated magnetic stir bar and under a nitrogen atmosphere, were added the crude mesylate from the previous step, anhydrous DMF $(0.5 \mathrm{M})$, and $\mathrm{NaN}_{3}$ (2.5 equiv). The reaction was heated to $70{ }^{\circ} \mathrm{C}$ and allowed to stir for $3 \mathrm{~h}$. After this time, the reaction mixture was allowed to cool to room temperature, poured carefully into a separatory funnel containing brine $(10 \mathrm{~mL})$, and extracted with $\mathrm{Et}_{2} \mathrm{O}(3 \times 15 \mathrm{~mL})$. The combined organic extracts were dried with $\mathrm{Na}_{2} \mathrm{SO}_{4}$, filtered, and concentrated in vacuo. The crude azide product was stored under nitrogen 
and carried on to the next step without further purification.

General Procedure for Staudinger Reduction: To an appropriately sized round-bottom flask equipped with a Teflon-coated magnetic stir bar were added the crude azide from the previous step and anhydrous diethyl ether $(0.5 \mathrm{M})$. The reaction mixture was cooled to $0{ }^{\circ} \mathrm{C}$, and the vessel was charged with $\mathrm{PPh}_{3}$ (1.5 equiv) and left to stir at $0{ }^{\circ} \mathrm{C}$. After $3 \mathrm{~h}, \mathrm{H}_{2} \mathrm{O}$ (2 equiv) was added, and the reaction mixture was allowed to warm to room temperature and stir overnight. The following morning, the reaction mixture was poured carefully into a separatory funnel containing $10 \% \mathrm{HCl}(20 \mathrm{~mL})$ and extracted with $\mathrm{Et}_{2} \mathrm{O}(3 \times 15 \mathrm{~mL})$. The organic extracts were discarded. The aqueous layer was treated with $6 \mathrm{~N} \mathrm{NaOH}$ solution until it reached a $\mathrm{pH}$ of 10 . The crude amine was extracted with diethyl ether $(5 \times 15 \mathrm{~mL})$, dried with $\mathrm{Na}_{2} \mathrm{SO}_{4}$, and concentrated in vacuo. The crude amine product was carried on to the next step without further purification.

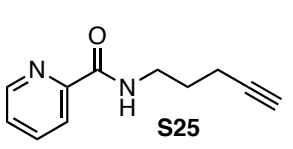

$N$-(pent-4-yn-1-yl)picolinamide (S25): The title compound was prepared using picolinoyl chloride hydrochloride $(1.88 \mathrm{~g}, 10.6 \mathrm{mmol})$ and pent-4-yn-1-amine $(0.87 \mathrm{~mL}, 8.8 \mathrm{mmol})$ according to the general procedure. Pent-4-yn-1-amine was prepared from pent-4-yn-1-ol following the amine synthesis procedure (Scheme S7). Purification using silica gel chromatography with 3:1 hexanes:EtOAc as the eluent gave the product as a colorless oil $\left(0.89 \mathrm{~g}, 54 \%\right.$ yield). ${ }^{1} \mathbf{H}$ NMR $\left(600 \mathrm{MHz}, \mathrm{CDCl}_{3}\right) \delta 8.55$ (ddd, $\left.J_{1}=4.8 \mathrm{~Hz}, J_{2}=1.7, J_{3}=0.9 \mathrm{~Hz}, 1 \mathrm{H}\right), 8.20\left(\mathrm{dt}, J_{1}=7.8 \mathrm{~Hz}, J_{2}=1.1 \mathrm{~Hz}, 1 \mathrm{H}\right), 8.18(\mathrm{~s}, 1 \mathrm{H}), 7.85$ $\left(\mathrm{td}, J_{1}=7.7 \mathrm{~Hz}, J_{2}=1.8 \mathrm{~Hz}, 1 \mathrm{H}\right), 7.43\left(\mathrm{ddd}, J_{l}=7.6 \mathrm{~Hz}, J_{2}=4.8 \mathrm{~Hz}, J_{3}=1.2 \mathrm{~Hz}, 1 \mathrm{H}\right), 3.60(\mathrm{td}$, $\left.J_{1}=6.9 \mathrm{~Hz}, J_{2}=6.2 \mathrm{~Hz}, 2 \mathrm{H}\right), 2.32\left(\mathrm{td}, J_{1}=7.0 \mathrm{~Hz}, J_{2}=2.7 \mathrm{~Hz}, 2 \mathrm{H}\right), 2.00(\mathrm{t}, J=2.7 \mathrm{~Hz}, 1 \mathrm{H})$, 1.89 (p, $J=6.9 \mathrm{~Hz}, 2 \mathrm{H}) ;{ }^{13} \mathrm{C}$ NMR $\left(150 \mathrm{MHz}, \mathrm{CDCl}_{3}\right) \delta 164.41,149.89,148.01,137.34,126.11$, 122.19, 83.35, 69.11, 38.40, 28.33, 16.15; HRMS (ESI-TOF) Calcd for $\mathrm{C}_{11} \mathrm{H}_{13} \mathrm{~N}_{2} \mathrm{O}^{+}[\mathrm{M}+\mathrm{H}]^{+}$ 189.1022 , found 189.1024 .

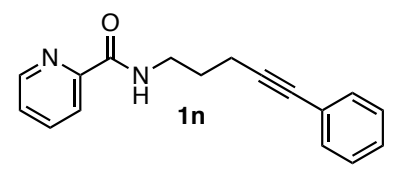

$N$-(5-phenylpent-4-yn-1-yl)picolinamide (1n): The title compound was prepared from $N$-(pent-4-yn-1-yl) picolinamide (S25) (828 mg, 4.4 $\mathrm{mmol}$ ) and iodobenzene (987 $\mathrm{mg}, 4.8 \mathrm{mmol}$ ) according to the general procedure. Purification using silica gel chromatography with 3:1 hexanes:EtOAc as the eluent gave the product as a brown powder (859 $\mathrm{mg}, 74 \%$ yield $).{ }^{1} \mathbf{H}$ NMR $\left(600 \mathrm{MHz}, \mathrm{CDCl}_{3}\right) \delta 8.46\left(\mathrm{ddd}, J_{l}=4.8 \mathrm{~Hz}, J_{l}=1.7 \mathrm{~Hz}, J_{l}=0.9 \mathrm{~Hz}, 1 \mathrm{H}\right), 8.27(\mathrm{bs}, 1 \mathrm{H})$, $8.20\left(\mathrm{dt}, J_{l}=7.8 \mathrm{~Hz}, J_{2}=1.1 \mathrm{~Hz}, 1 \mathrm{H}\right), 7.84\left(\mathrm{td}, J_{1}=7.7 \mathrm{~Hz}, J_{2}=1.7 \mathrm{~Hz}, 1 \mathrm{H}\right), 7.41-7.38(\mathrm{~m}, 3 \mathrm{H})$, $7.29-7.26(\mathrm{~m}, 3 \mathrm{H}), 3.66(\mathrm{q}, J=6.6 \mathrm{~Hz}, 2 \mathrm{H}), 2.56(\mathrm{t}, J=6.9 \mathrm{~Hz}, 2 \mathrm{H}), 1.97(\mathrm{p}, J=6.8 \mathrm{~Hz}, 2 \mathrm{H})$; ${ }^{13}$ C NMR $\left(150 \mathrm{MHz}, \mathrm{CDCl}_{3}\right) \delta 164.41,149.92,147.99,137.30,131.60,128.16,127.64,126.06$, 123.72, 122.16, 88.96, 81.45, 38.78, 28.55, 17.32; HRMS (ESI-TOF) Calcd for $\mathrm{C}_{17} \mathrm{H}_{17} \mathrm{~N}_{2} \mathrm{O}^{+}$ $[\mathrm{M}+\mathrm{H}]^{+} 265.1335$, found 265.1338 . 


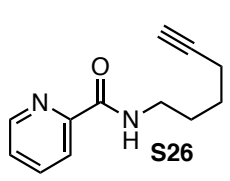

$\mathrm{N}$-(hex-5-yn-1-yl)picolinamide (S26): The title compound was prepared using picolinoyl chloride hydrochloride $(1.36 \mathrm{~g}, 7.6 \mathrm{mmol})$ and hex-5-yn-1-amine $(0.73$ $\mathrm{mL}, 6.4 \mathrm{mmol}$ ) according to the general procedure. Hex-5-yn-1-amine was prepared from hex-5-yn-1-ol following the amine synthesis procedure (Scheme S7). Purification using silica gel chromatography with 3:1 hexanes:EtOAc as the eluent gave the product as a colorless oil $\left(0.64 \mathrm{~g}, 50 \%\right.$ yield). ${ }^{1} \mathbf{H}$ NMR $\left(600 \mathrm{MHz}, \mathrm{CDCl}_{3}\right) \delta 8.55$ (ddd, $J_{I}=4.8$ $\left.\mathrm{Hz}, J_{2}=1.7, J_{3}=0.9 \mathrm{~Hz}, 1 \mathrm{H}\right), 8.20\left(\mathrm{dt}, J_{1}=7.8 \mathrm{~Hz}, J_{2}=1.1 \mathrm{~Hz}, 1 \mathrm{H}\right), 8.08(\mathrm{~s}, 1 \mathrm{H}), 7.85\left(\mathrm{td}, J_{1}=\right.$ $\left.7.7 \mathrm{~Hz}, J_{2}=1.7 \mathrm{~Hz}, 1 \mathrm{H}\right), 7.42\left(\mathrm{ddd}, J_{1}=7.6 \mathrm{~Hz}, J_{2}=4.8 \mathrm{~Hz}, J_{3}=1.2 \mathrm{~Hz}, 1 \mathrm{H}\right), 3.51\left(\mathrm{td}, J_{1}=7.1\right.$ $\left.\mathrm{Hz}, J_{2}=6.1 \mathrm{~Hz}, 2 \mathrm{H}\right), 2.26\left(\mathrm{td}, J_{l}=7.0 \mathrm{~Hz}, J_{2}=2.6 \mathrm{~Hz}, 2 \mathrm{H}\right), 1.96(\mathrm{t}, J=2.6 \mathrm{~Hz}, 1 \mathrm{H}), 1.80-1.75$ $(\mathrm{m}, 2 \mathrm{H}), 1.67-1.62(\mathrm{~m}, 2 \mathrm{H}) ;{ }^{13} \mathbf{C}$ NMR $\left(150 \mathrm{MHz}, \mathrm{CDCl}_{3}\right) \delta 164.28,149.96,148.00,137.34$, 126.07, 122.19, 84.01, 68.66, 38.85, 28.77, 25.79, 18.14; HRMS (ESI-TOF) Calcd for $\mathrm{C}_{12} \mathrm{H}_{15} \mathrm{~N}_{2} \mathrm{O}^{+}[\mathrm{M}+\mathrm{H}]^{+}$203.1179, found 203.1178.

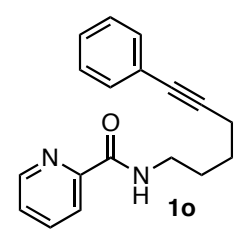

N-(6-phenylhex-5-yn-1-yl)picolinamide (10): The title compound was prepared from $N$-(hex-5-yn-1-yl) picolinamide (S26) $(506 \mathrm{mg}, 2.5 \mathrm{mmol})$ and iodobenzene (561 mg, $2.8 \mathrm{mmol}$ ) according to the general procedure. Purification using silica gel chromatography with $3: 1$ hexanes:EtOAc as the eluent gave the product as a red oil $\left(650 \mathrm{mg}, 93 \%\right.$ yield). ${ }^{1} \mathbf{H}$ NMR $\left(600 \mathrm{MHz}, \mathrm{CDCl}_{3}\right) \delta 8.54$ (ddd, $J_{l}=4.8$ $\left.\mathrm{Hz}, J_{l}=1.7 \mathrm{~Hz}, J_{1}=0.9 \mathrm{~Hz}, 1 \mathrm{H}\right), 8.20\left(\mathrm{dt}, J_{1}=7.8 \mathrm{~Hz}, J_{2}=1.1 \mathrm{~Hz}, 1 \mathrm{H}\right), 8.11(\mathrm{bs}, 1 \mathrm{H}), 7.85(\mathrm{td}$, $\left.J_{1}=7.7 \mathrm{~Hz}, J_{2}=1.7 \mathrm{~Hz}, 1 \mathrm{H}\right), 7.43-7.38(\mathrm{~m}, 3 \mathrm{H}), 7.29-7.25(\mathrm{~m}, 3 \mathrm{H}), 3.55\left(\mathrm{td}, J_{1}=7.0 \mathrm{~Hz}, J_{2}=\right.$ $6.1 \mathrm{~Hz}, 2 \mathrm{H}), 2.48(\mathrm{t}, J=7.0 \mathrm{~Hz}, 2 \mathrm{H}), 1.86-1.70(\mathrm{~m}, 4 \mathrm{H}) ;{ }^{13} \mathbf{C}$ NMR $\left(150 \mathrm{MHz}, \mathrm{CDCl}_{3}\right) \delta 164.28$, $149.98,147.99,137.33,131.55,128.16,127.56,126.05,123.84,122.18,89.62,81.03,38.93$, 28.94, 26.10, 19.15; HRMS (ESI-TOF) Calcd for $\mathrm{C}_{18} \mathrm{H}_{19} \mathrm{~N}_{2} \mathrm{O}^{+}[\mathrm{M}+\mathrm{H}]^{+}$279.1492, found 279.1492 .

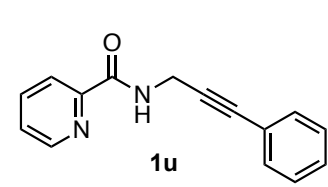

$N$-(3-phenylprop-2-yn-1-yl)picolinamide (1u): The title compound was prepared from $N$-(prop-2-yn-1-yl) picolinamide ${ }^{10}(160 \mathrm{mg}, 1.0 \mathrm{mmol})$ and iodobenzene $(265 \mathrm{mg}, 1.3 \mathrm{mmol}$ ) according to the general procedure. Purification using silica gel chromatography with 2:1 hexanes:EtOAc as the eluent gave the product as a yellow solid $\left(231 \mathrm{mg}, 98 \%\right.$ yield). ${ }^{1} \mathbf{H}$ NMR $\left(500 \mathrm{MHz}, \mathrm{CDCl}_{3}\right) \delta$ $8.58(\mathrm{~d}, J=4.9 \mathrm{~Hz}, 1 \mathrm{H}), 8.27$ (bs, 1H), 8.21 (d, $J=7.9 \mathrm{~Hz}, 1 \mathrm{H}), 7.86$ (td, $J_{1}=7.7 \mathrm{~Hz}, J_{2}=1.7$ $\mathrm{Hz}, 1 \mathrm{H}), 7.48-7.40(\mathrm{~m}, 3 \mathrm{H}), 7.34-7.24(\mathrm{~m}, 3 \mathrm{H}), 4.51(\mathrm{~d}, J=5.5,2 \mathrm{H}) ;{ }^{13} \mathbf{C}$ NMR $(125 \mathrm{MHz}$, $\left.\mathrm{CDCl}_{3}\right) \delta 163.94,149.51,148.15,137.34,131.76,128.36,128.24,126.34,122.62,122.35,84.69$, 83.37, 29.98; HRMS (ESI-TOF) Calcd for $\mathrm{C}_{15} \mathrm{H}_{13} \mathrm{~N}_{2} \mathrm{O}^{+}[\mathrm{M}+\mathrm{H}]^{+}$237.1022, found 237.1020. 
Synthesis of 4-Alkyl and 4-TMS Homopropargyl Picolinamide Substrates $\mathbf{1}$-t: ${ }^{8}$

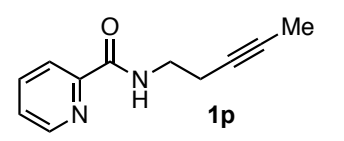

N-(pent-3-yn-1-yl)picolinamide (1p): The title compound was prepared using picolinoyl chloride hydrochloride and pent-3-yn-1-amine according to the general procedure. Pent-3-yn-1-amine was prepared from pent-3-yn-1-ol (420 mg, $5.0 \mathrm{mmol}$ ) following the amine synthesis procedure (Scheme S7). Purification using silica gel chromatography with 3:1 hexanes:EtOAc as the eluent gave the product as a colorless oil (508 mg, 54\% yield for 4 steps). ${ }^{1} \mathbf{H}$ NMR (500 MHz, $\left.\mathrm{CDCl}_{3}\right) \delta 8.56(\mathrm{~d}, J=4.8 \mathrm{~Hz}, 1 \mathrm{H}), 8.33$ (bs, $1 \mathrm{H}), 8.20(\mathrm{~d}, J=7.8 \mathrm{~Hz}, 1 \mathrm{H}), 7.84\left(\mathrm{td}, J_{1}=7.7 \mathrm{~Hz}, J_{2}=1.7 \mathrm{~Hz}, 1 \mathrm{H}\right), 7.43$ (ddd, $J_{1}=7.6 \mathrm{~Hz}$, $\left.J_{2}=4.8 \mathrm{~Hz}, J_{3}=1.2 \mathrm{~Hz}, 1 \mathrm{H}\right), 3.60(\mathrm{q}, J=6.6 \mathrm{~Hz}, 2 \mathrm{H}), 2.47\left(\mathrm{tq}, J_{1}=6.8 \mathrm{~Hz}, J_{2}=2.5 \mathrm{~Hz}, 2 \mathrm{H}\right)$, $1.81(\mathrm{t}, J=2.5 \mathrm{~Hz}, 3 \mathrm{H}) ;{ }^{13} \mathbf{C}$ NMR $\left(125 \mathrm{MHz}, \mathrm{CDCl}_{3}\right) \delta 164.20,149.77,147.99,137.17,126.01$, 122.09, 77.26, 75.98, 38.55, 19.72, 3.40; HRMS (ESI-TOF) Calcd for $\mathrm{C}_{11} \mathrm{H}_{13} \mathrm{~N}_{2} \mathrm{O}^{+}[\mathrm{M}+\mathrm{H}]^{+}$ 189.1022 , found 189.1024 .

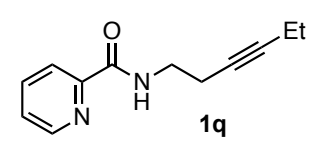

$\mathbf{N}$-(hex-3-yn-1-yl)picolinamide (1q): The title compound was prepared using picolinoyl chloride hydrochloride and hex-3-yn-1-amine according to the general procedure. Hex-3-yn-1-amine was prepared from hex-3-yn-1-ol (490 $\mathrm{mg}, 5.0 \mathrm{mmol}$ ) following the amine synthesis procedure (Scheme S7). Purification using silica gel chromatography with 3:1 hexanes:EtOAc as the eluent gave the product as a white powder (515 mg, 51\% yield for 4 steps). ${ }^{1} \mathbf{H}$ NMR $\left(500 \mathrm{MHz}, \mathrm{CDCl}_{3}\right) \delta 8.56(\mathrm{~d}, J=4.6 \mathrm{~Hz}, 1 \mathrm{H})$, $8.33(\mathrm{bs}, 1 \mathrm{H}), 8.20(\mathrm{~d}, J=7.9 \mathrm{~Hz}, 1 \mathrm{H}), 7.85\left(\mathrm{td}, J_{1}=7.7 \mathrm{~Hz}, J_{2}=1.7 \mathrm{~Hz}, 1 \mathrm{H}\right), 7.42\left(\mathrm{ddd}, J_{1}=7.6\right.$ $\left.\mathrm{Hz}, J_{2}=4.7 \mathrm{~Hz}, J_{3}=1.2 \mathrm{~Hz}, 1 \mathrm{H}\right), 3.60(\mathrm{q}, J=6.6 \mathrm{~Hz}, 2 \mathrm{H}), 2.48\left(\mathrm{tt}, J_{1}=6.7 \mathrm{~Hz}, J_{2}=2.4 \mathrm{~Hz}\right.$, 2H), 2.19 (qt, $\left.J_{1}=7.5 \mathrm{~Hz}, J_{2}=2.4 \mathrm{~Hz}, 2 \mathrm{H}\right), 1.14(\mathrm{t}, J=7.5 \mathrm{~Hz}, 3 \mathrm{H}) ;{ }^{13} \mathbf{C} \mathbf{N M R}(125 \mathrm{MHz}$, $\left.\mathrm{CDCl}_{3}\right) \delta 164.24,149.91,148.05,137.26,126.08,122.18,83.67,76.21,38.58,19.83,14.16$, 12.40; HRMS (ESI-TOF) Calcd for $\mathrm{C}_{12} \mathrm{H}_{15} \mathrm{~N}_{2} \mathrm{O}^{+}[\mathrm{M}+\mathrm{H}]^{+}$203.1179, found 203.1183.

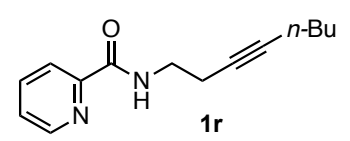

N-(oct-3-yn-1-yl)picolinamide (1r): The title compound was prepared using picolinoyl chloride hydrochloride and oct-3-yn-1-amine according to the general procedure. Oct-3-yn-1-amine was prepared from oct-3-yn-1-ol (504 mg, $4.0 \mathrm{mmol}$ ) following the amine synthesis procedure (Scheme S7). Purification using silica gel chromatography with 3:1 hexanes:EtOAc as the eluent gave the product as a yellow oil (486 mg, 53\% yield for 4 steps). ${ }^{1} \mathbf{H}$ NMR $\left(600 \mathrm{MHz}, \mathrm{CDCl}_{3}\right) \delta 8.56$ (ddd, $J_{1}=4.7 \mathrm{~Hz}, J_{2}=1.7$ $\left.\mathrm{Hz}, J_{3}=0.9 \mathrm{~Hz}, 1 \mathrm{H}\right), 8.34$ (bs, $\left.1 \mathrm{H}\right), 8.20\left(\mathrm{dt}, J_{1}=7.8 \mathrm{~Hz}, J_{2}=1.1 \mathrm{~Hz}, 1 \mathrm{H}\right), 7.85\left(\mathrm{td}, J_{1}=7.7 \mathrm{~Hz}\right.$, $\left.J_{2}=1.7 \mathrm{~Hz}, 1 \mathrm{H}\right), 7.42\left(\mathrm{ddd}, J_{1}=7.6 \mathrm{~Hz}, J_{2}=4.8 \mathrm{~Hz}, J_{3}=1.3 \mathrm{~Hz}, 1 \mathrm{H}\right), 3.60\left(\mathrm{td}, J_{1}=6.7 \mathrm{~Hz}, J_{2}=\right.$ $6.1 \mathrm{~Hz}, 2 \mathrm{H}), 2.49\left(\mathrm{tt}, J_{l}=6.7 \mathrm{~Hz}, J_{2}=2.4 \mathrm{~Hz}, 2 \mathrm{H}\right), 2.18\left(\mathrm{tt}, J_{l}=7.1 \mathrm{~Hz}, J_{2}=2.4 \mathrm{~Hz}, 2 \mathrm{H}\right)$, $1.51-1.38(\mathrm{~m}, 4 \mathrm{H}), 0.90(\mathrm{t}, J=7.3 \mathrm{~Hz}, 3 \mathrm{H}) ;{ }^{13} \mathbf{C}$ NMR $\left(150 \mathrm{MHz}, \mathrm{CDCl}_{3}\right) \delta 164.25,149.92$, $148.06,137.27,126.09,122.20,109.98,82.31,38.60,31.01,21.89,19.86,18.41,13.63$; HRMS (ESI-TOF) Calcd for $\mathrm{C}_{14} \mathrm{H}_{19} \mathrm{~N}_{2} \mathrm{O}^{+}[\mathrm{M}+\mathrm{H}]^{+} 231.1492$, found 231.1490. 


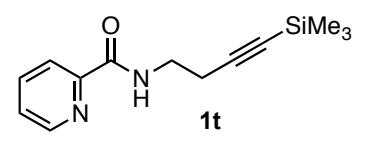

$N$-(4-(trimethylsilyl)but-3-yn-1-yl)picolinamide (1t): The title compound was prepared using picolinoyl chloride hydrochloride and 4-(trimethylsilyl)but-3-yn-1-amine according to the general procedure. 4-(Trimethylsilyl)but-3-yn-1-amine was prepared from 4-(trimethylsilyl)but-3-yn-1-ol (2.85 g, $20 \mathrm{mmol}$ ) following the amine synthesis procedure (Scheme S7). (Note: Following the Staudinger reduction step, 4-(trimethylsilyl)but-3-yn-1-amine was purified by distillation rather than acid/base workup to avoid potential cleavage of the $\mathrm{C}-\mathrm{Si}$ bond.) Purification using silica gel chromatography with 3:1 hexanes:EtOAc as the eluent gave the product as a white solid $(2.27 \mathrm{~g}$, $34 \%$ yield for 4 steps). ${ }^{1} \mathbf{H}$ NMR $\left(500 \mathrm{MHz}, \mathrm{CDCl}_{3}\right) \delta 8.60-8.52(\mathrm{~m}, 1 \mathrm{H}), 8.39(\mathrm{bs}, 1 \mathrm{H}), 8.20(\mathrm{~d}$, $J=7.8 \mathrm{~Hz}, 1 \mathrm{H}), 7.85(\mathrm{dd}, J=8.4,6.8 \mathrm{~Hz}, 1 \mathrm{H}), 7.43(\mathrm{dd}, J=7.6,4.8 \mathrm{~Hz}, 1 \mathrm{H}), 3.63(\mathrm{q}, J=6.6$ $\mathrm{Hz}, 2 \mathrm{H}), 2.55(\mathrm{t}, J=6.7 \mathrm{~Hz}, 2 \mathrm{H}), 0.17(\mathrm{~s}, 9 \mathrm{H}) ;{ }^{13} \mathbf{C}$ NMR $\left(125 \mathrm{MHz}, \mathrm{CDCl}_{3}\right) \delta 164.25,149.84$, 148.07, 137.27, 126.13, 122.17, 103.81, 86.88, 37.95, 20.91, 0.00; HRMS (ESI-TOF) Calcd for $\mathrm{C}_{13} \mathrm{H}_{19} \mathrm{~N}_{2} \mathrm{OSi}^{+}[\mathrm{M}+\mathrm{H}]^{+}$247.1261, found 247.1260.

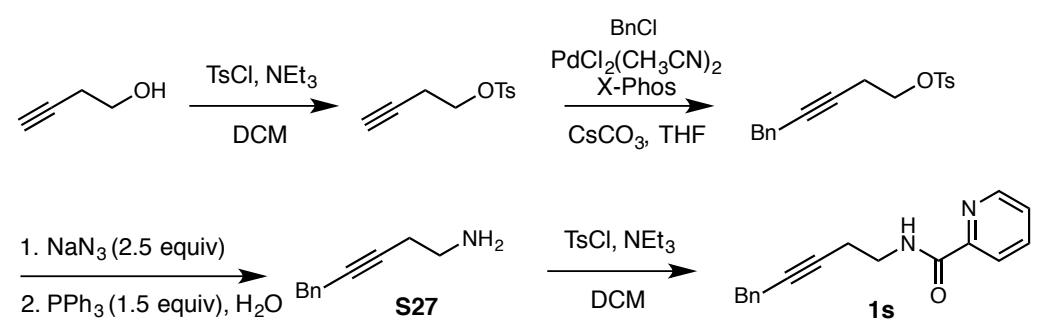

Scheme S8: Synthesis of $N$-(5-phenylpent-3-yn-1-yl)picolinamide (1s).

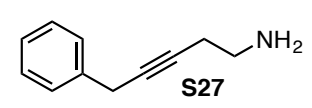

5-phenylpent-3-yn-1-amine (S27): To a 150-mL round-bottom flask equipped with a Teflon-coated magnetic stir bar were added sulfonyl chloride (11.0 mmol, 1.1 equiv) and anhydrous dichloromethane (35 $\mathrm{mL})$. But-3-yn-1-ol $(0.7 \mathrm{~g}, 10.0 \mathrm{mmol})$ was added dropwise at $0{ }^{\circ} \mathrm{C}$, followed by dropwise addition of triethylamine $(3.0 \mathrm{~mL}, 2.1$ equiv). The reaction was allowed to warm to room temperature and stir overnight. Upon completion, the reaction mixture was quenched with aqueous $\mathrm{NaHCO}_{3}$ and extracted with DCM $(3 \times 15 \mathrm{~mL})$. The combined organic extracts were then dried with $\mathrm{Na}_{2} \mathrm{SO}_{4}$, filtered, and concentrated in vacuo. Purification using silica gel chromatography gave the product but-3-yn-1-yl 4-methylbenzenesulfonate as a colorless liquid (2.02 g, 90\% yield). Benzylation of this terminal alkyne intermediate according to a literature procedure gave 5-phenylpent-3-yn-1-yl 4-methylbenzenesulfonate. ${ }^{11}$ The amine product was obtained after azide displacement and Staudinger reduction following the amine synthesis procedure described above and was carried on to the next step without further purification (Scheme S7).

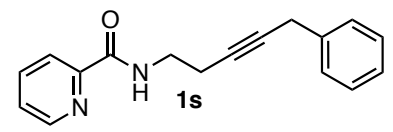

$N$-(5-phenylpent-3-yn-1-yl)picolinamide (1s): The title compound was prepared according to the general procedure. Purification using silica gel 
chromatography with 3:1 hexanes:EtOAc as the eluent gave the product as a yellow solid $(1.2 \mathrm{~g}$, $42 \%$ yield for 5 steps). ${ }^{1} \mathbf{H}$ NMR $\left(600 \mathrm{MHz}, \mathrm{CDCl}_{3}\right) \delta 8.55$ (ddd, $J_{1}=4.8 \mathrm{~Hz}, J_{2}=1.7 \mathrm{~Hz}, J_{3}=$ $0.9 \mathrm{~Hz}, 1 \mathrm{H}), 8.37(\mathrm{bs}, 1 \mathrm{H}), 8.20\left(\mathrm{dt}, J_{1}=7.8 \mathrm{~Hz}, J_{2}=1.1 \mathrm{~Hz}, 1 \mathrm{H}\right), 7.85\left(\mathrm{td}, J_{1}=7.7 \mathrm{~Hz}, J_{2}=1.8\right.$ $\mathrm{Hz}, 1 \mathrm{H}), 7.43\left(\mathrm{ddd}, J_{1}=7.6 \mathrm{~Hz}, J_{2}=4.8 \mathrm{~Hz}, J_{3}=1.2 \mathrm{~Hz}, 1 \mathrm{H}\right), 7.36-7.35(\mathrm{~m}, 2 \mathrm{H}), 7.30-7.27(\mathrm{~m}$, 2H), 7.23-7.20 (m, 1H), $3.65(\mathrm{q}, J=6.6 \mathrm{~Hz}, 2 \mathrm{H}), 3.61\left(\mathrm{dt}, J_{1}=2.3 \mathrm{~Hz}, J_{2}=1.4 \mathrm{~Hz}, 2 \mathrm{H}\right), 2.57(\mathrm{tt}$, $\left.J_{1}=6.7 \mathrm{~Hz}, J_{2}=2.4 \mathrm{~Hz}, 2 \mathrm{H}\right) ;{ }^{13} \mathbf{C}$ NMR $\left(150 \mathrm{MHz}, \mathrm{CDCl}_{3}\right) \delta 164.31,149.85,148.08,137.30$, $137.11,128.42,127.85,126.45,126.13,122.22,79.61,79.31,38.54,25.12,19.95$; HRMS (ESI-TOF) Calcd for $\mathrm{C}_{17} \mathrm{H}_{17} \mathrm{~N}_{2} \mathrm{O}^{+}[\mathrm{M}+\mathrm{H}]^{+}$265.1335, found 265.1336. 


\section{General Procedure for Hydroarylation of Picolinamides}

General Procedure: To a 5-mL scintillation vial equipped with a Teflon-coated magnetic stir bar were added the homopropargyl picolinamide substrate $(0.1 \mathrm{mmol})$, the appropriate boronic acid (0.18 mmol), $\mathrm{Pd}(\mathrm{OAc})_{2}(5 \mathrm{~mol} \%), \mathrm{PCy}_{3} \cdot \mathrm{HBF}_{4}(5 \mathrm{~mol} \%)$, and $\mathrm{KOAc}(0.1 \mathrm{mmol})$. The vial was sealed with a screw-top septum cap and was then evacuated and backfilled with $\mathrm{N}_{2}$ three times. Under a positive pressure of $\mathrm{N}_{2}$, anhydrous dioxane $(0.4 \mathrm{~mL})$ was added. All needle inlets/outlets were removed, and the reaction was allowed to stir at $90{ }^{\circ} \mathrm{C}$ for $4 \mathrm{~h}$. After this time, the reaction vial was allowed cooled to room temperature, and the reaction mixture was filtered through a short plug of silica gel (1:1 hexanes:EtOAc, $10 \mathrm{~mL}$, as eluent). The solvent was removed in vacuo to leave a brown residue, which upon purification by silica gel column chromatography, afforded pure product.
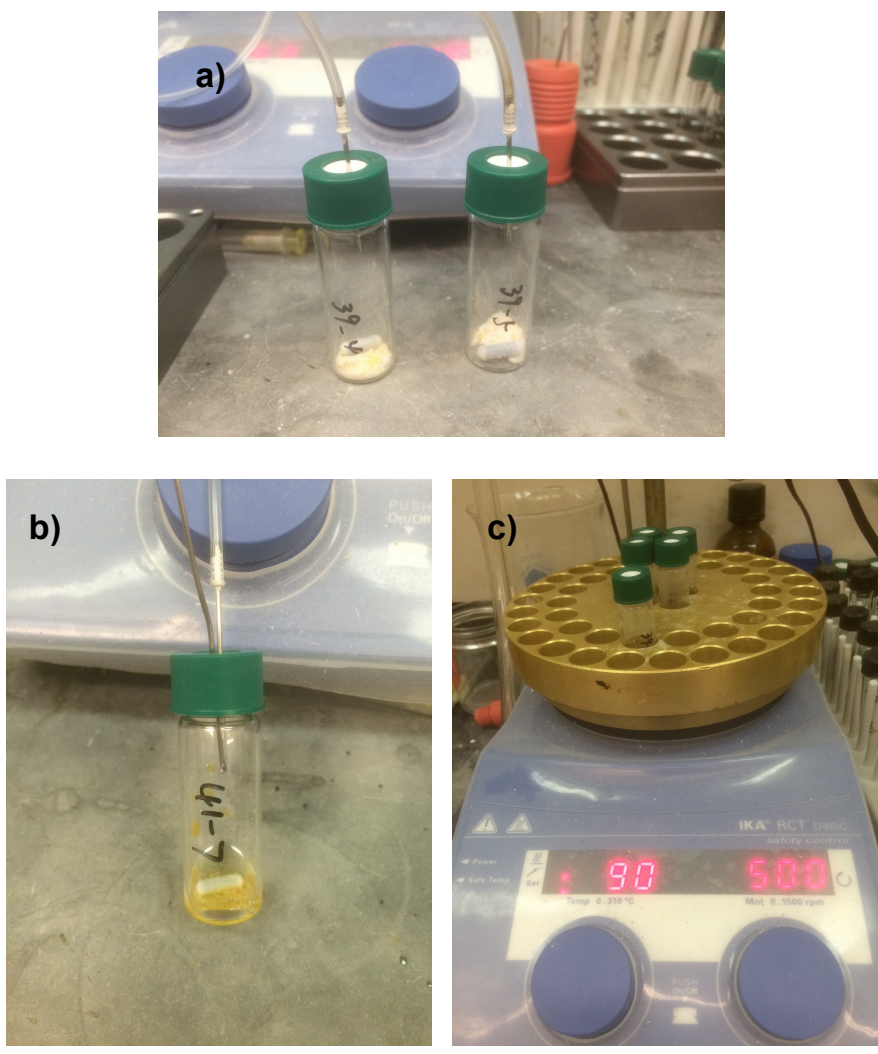

Figure S1: Photographic depiction of reaction setup following general procedure.

a) Degassing and back-filling with $\mathrm{N}_{2}$. b) Injecting anhydrous solvent under positive $\mathrm{N}_{2}$ pressure. c) Heating in stir plate. 


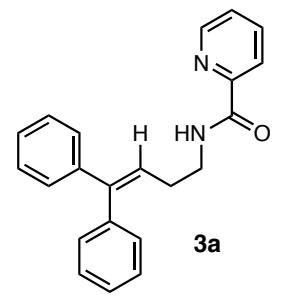

$N$-(4,4-diphenylbut-3-en-1-yl)picolinamide (3a): The title compound was prepared using 1a $(25 \mathrm{mg}, 0.1 \mathrm{mmol})$, and phenylboronic acid (22 $\mathrm{mg}, 0.18$ mmol) according to the general procedure. Purification using silica gel chromatography with 3:1 hexanes:EtOAc as the eluent gave the product as a white solid (25.6 mg, 78\% yield). ${ }^{1} \mathbf{H}$ NMR (600 MHz, $\left.\mathrm{CDCl}_{3}\right) \delta 8.52(\mathrm{~d}, J=$ $4.7 \mathrm{~Hz}, 1 \mathrm{H}), 8.18(\mathrm{~d}, J=7.8,1 \mathrm{H}), 8.07(\mathrm{bs}, 1 \mathrm{H}), 7.83(\mathrm{td}, J=7.7,1.7 \mathrm{~Hz}, 1 \mathrm{H})$, 7.40 (ddd, $J=7.6,4.8,1.3 \mathrm{~Hz}, 1 \mathrm{H}), 7.35-7.26(\mathrm{~m}, 4 \mathrm{H}), 7.25-7.20$ (m, 4H), 7.18-7.16 (m, 2H), $6.13(\mathrm{t}, J=7.5 \mathrm{~Hz}, 1 \mathrm{H}), 3.58(\mathrm{q}, J=6.9,2 \mathrm{H}), 2.46$ (q, $J=7.1 \mathrm{~Hz}, 2 \mathrm{H}) ;{ }^{13} \mathbf{C} \mathbf{N M R}(150 \mathrm{MHz}$, $\left.\mathrm{CDCl}_{3}\right) \delta 164.19,149.92,147.95,144.13,142.24,139.74,137.28,129.78,128.24,128.09$, 127.23, 127.09, 126.03, 125.68, 122.14, 39.25, 30.12; HRMS (ESI-TOF) Calcd for $\mathrm{C}_{22} \mathrm{H}_{20} \mathrm{~N}_{2} \mathrm{O}^{+}$ $[\mathrm{M}+\mathrm{H}]^{+} 329.1648$, found 329.1649 .

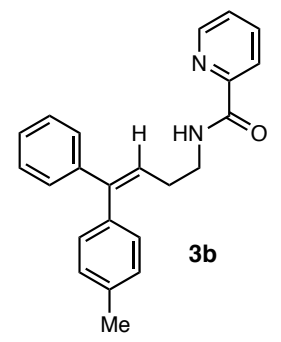

(Z)-N-(4-phenyl-4-(p-tolyl)but-3-en-1-yl)picolinamide (3b): The title compound was prepared from $\mathbf{1 b}(26.4 \mathrm{mg}, 0.1 \mathrm{mmol})$ and phenylboronic acid (22 $\mathrm{mg}, 0.18 \mathrm{mmol}$ ) according to the general procedure. Purification using silica gel chromatography with 3:1 hexanes:EtOAc as the eluent gave the product as a white solid (23.9 $\mathrm{mg}, 70 \%$ yield). ${ }^{1} \mathbf{H}$ NMR $\left(600 \mathrm{MHz}, \mathrm{CDCl}_{3}\right) \delta$ $8.52(\mathrm{~d}, J=3.6 \mathrm{~Hz}, 1 \mathrm{H}), 8.18(\mathrm{~d}, J=7.8,1 \mathrm{H}), 8.07(\mathrm{bs}, 1 \mathrm{H}), 7.83\left(\mathrm{td}, J_{1}=7.7\right.$ $\left.\mathrm{Hz}, J_{2}=1.8 \mathrm{~Hz}, 1 \mathrm{H}\right), 7.40\left(\mathrm{ddd}, J_{1}=7.6 \mathrm{~Hz}, J_{2}=4.8 \mathrm{~Hz}, J_{3}=1.3 \mathrm{~Hz}, 1 \mathrm{H}\right), 7.25-7.20(\mathrm{~m}, 5 \mathrm{H})$, $7.15(\mathrm{~d}, J=7.7 \mathrm{~Hz}, 2 \mathrm{H}), 7.06(\mathrm{~d}, J=7.7 \mathrm{~Hz}, 2 \mathrm{H}), 6.10(\mathrm{t}, J=7.5 \mathrm{~Hz}, 1 \mathrm{H}), 3.58(\mathrm{q}, J=6.7 \mathrm{~Hz}$, 2H), $2.47(\mathrm{q}, J=7.2 \mathrm{~Hz}, 2 \mathrm{H}), 2.36(\mathrm{~s}, 3 \mathrm{H}) ;{ }^{13} \mathbf{C} \mathbf{N M R}\left(125 \mathrm{MHz}, \mathrm{CDCl}_{3}\right) \delta 164.19,149.96$, $147.95,144.09,142.49,137.27,136.75,136.71,129.68,128.94,128.05,127.27,127.03,126.01$, 125.48, 122.14, 39.31, 30.13, 21.20; HRMS (ESI-TOF) Calcd for $\mathrm{C}_{23} \mathrm{H}_{22} \mathrm{~N}_{2} \mathrm{O}^{+}[\mathrm{M}+\mathrm{H}]^{+}$ 343.1805, found 343.1809. X-ray (single-crystal) Colorless block crystals of X-ray diffraction quality were obtained by vapor diffusion of pentanes into a saturated solution of $\mathbf{3 b}$ in DCM (CCDC 1465202). ${ }^{12}$

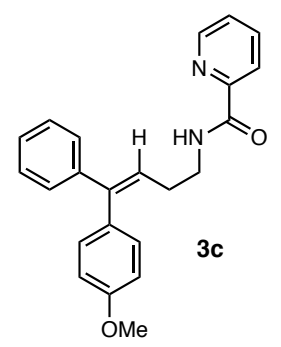

(Z)-N-(4-(4-methoxyphenyl)-4-phenylbut-3-en-1-yl)picolinamide (3c): The title compound was prepared from $1 \mathrm{c}(28 \mathrm{mg}, 0.1 \mathrm{mmol})$ and phenylboronic acid (22 $\mathrm{mg}, 0.18 \mathrm{mmol}$ ) according to the general procedure. Purification using silica gel chromatography with 3:1 hexanes:EtOAc as the eluent gave the product as a white solid (31.1 $\mathrm{mg}, 87 \%$ yield). ${ }^{1} \mathbf{H}$ NMR $\left(600 \mathrm{MHz}, \mathrm{CDCl}_{3}\right) \delta$ $8.53(\mathrm{~d}, J=4.7 \mathrm{~Hz}, 1 \mathrm{H}), 8.18\left(\mathrm{dq}, J_{l}=7.8 \mathrm{~Hz}, J_{2}=1.0 \mathrm{~Hz}, 1 \mathrm{H}\right), 8.08(\mathrm{~s}, 1 \mathrm{H})$, $7.83\left(\mathrm{tdd}, J_{1}=7.6 \mathrm{~Hz}, J_{2}=1.7 \mathrm{~Hz}, J_{3}=0.8 \mathrm{~Hz}, 1 \mathrm{H}\right), 7.43-7.41(\mathrm{~m}, 1 \mathrm{H})$, 7.27-7.20 (m, 5H), 7.10-7.08 (m, 2H), 6.88-6.86 (m, 2H), $6.08(\mathrm{t}, J=7.4 \mathrm{~Hz}, 1 \mathrm{H}), 3.82(\mathrm{~s}, 3 \mathrm{H})$, $3.58(\mathrm{q}, J=6.7 \mathrm{~Hz}, 2 \mathrm{H}), 2.49$ (q, $J=7.1 \mathrm{~Hz}, 2 \mathrm{H}) ;{ }^{13} \mathbf{C} \mathbf{N M R}\left(150 \mathrm{MHz}, \mathrm{CDCl}_{3}\right) \delta 164.22$, $158.63,149.93,147.97,143.75,142.68,137.30,132.02$, 130.95, 128.06, 127.33, 127.06, 126.05, 
125.45, 122.16, 113.63, 55.22, 39.34, 30.15; HRMS (ESI-TOF) Calcd for $\mathrm{C}_{23} \mathrm{H}_{22} \mathrm{~N}_{2} \mathrm{O}_{2}{ }^{+}[\mathrm{M}+\mathrm{H}]^{+}$ 359.1754 , found 359.1753 .

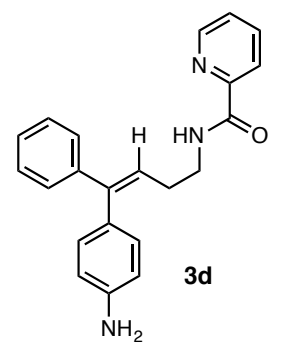

(Z)-N-(4-(4-aminophenyl)-4-phenylbut-3-en-1-yl)picolinamide (3d): The title compound was prepared from $1 \mathbf{d}(26.5 \mathrm{mg}, 0.1 \mathrm{mmol})$ and phenyl boronic acid (22 mg, $0.18 \mathrm{mmol}$ ) according to the general procedure. Purification using silica gel chromatography with 1:1 hexanes:EtOAc as the eluent gave the product as a colorless oil (28.8 $\mathrm{mg}, 84 \%$ yield). ${ }^{1} \mathbf{H}$ NMR $\left(600 \mathrm{MHz}, \mathrm{CDCl}_{3}\right) \delta$ $8.52\left(\mathrm{ddd}, J_{1}=4.8 \mathrm{~Hz}, J_{2}=1.8 \mathrm{~Hz}, J_{3}=0.9 \mathrm{~Hz}, 1 \mathrm{H}\right), 8.19\left(\mathrm{dt}, J_{1}=7.8 \mathrm{~Hz}, J_{2}=\right.$ $1.1 \mathrm{~Hz}, 1 \mathrm{H}), 8.08(\mathrm{bs}, 1 \mathrm{H}), 7.83\left(\mathrm{td}, J_{I}=7.7 \mathrm{~Hz}, J_{2}=1.7 \mathrm{~Hz}, 1 \mathrm{H}\right), 7.40\left(\mathrm{ddd}, J_{1}\right.$ $\left.=7.6 \mathrm{~Hz}, J_{2}=4.8 \mathrm{~Hz}, J_{3}=1.2 \mathrm{~Hz}, 1 \mathrm{H}\right), 7.26-7.15(\mathrm{~m}, 5 \mathrm{H}), 7.04-6.90(\mathrm{~m}, 2 \mathrm{H}), 6.73-6.61(\mathrm{~m}$, $2 \mathrm{H}), 6.02(\mathrm{t}, J=7.4 \mathrm{~Hz}, 1 \mathrm{H}), 3.68(\mathrm{~s}, 2 \mathrm{H}), 3.58\left(\mathrm{td}, J_{1}=7.1 \mathrm{~Hz}, J_{2}=6.0 \mathrm{~Hz}, 2 \mathrm{H}\right), 2.51(\mathrm{q}, J=7.1$ $\mathrm{Hz}, 2 \mathrm{H}) ;{ }^{13} \mathrm{C}$ NMR $\left(150 \mathrm{MHz}, \mathrm{CDCl}_{3}\right) \delta 164.19,149.97,147.96,145.38,144.08,143.01$, 137.26, 130.86, 129.88, 128.00, 127.44, 126.95, 126.00, 125.01, 122.13, 114.79, 39.41, 30.16; HRMS (ESI-TOF) Calcd for $\mathrm{C}_{22} \mathrm{H}_{21} \mathrm{~N}_{3} \mathrm{O}^{+}[\mathrm{M}+\mathrm{H}]^{+} 344.1757$, found 344.1755.

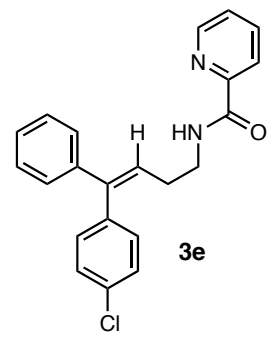

(Z)-N-(4-(4-chlorophenyl)-4-phenylbut-3-en-1-yl)picolinamide (3e): The title compound was prepared from $1 \mathrm{e}(28.5 \mathrm{mg}, 0.1 \mathrm{mmol})$ and phenylboronic acid (22 $\mathrm{mg}, 0.18 \mathrm{mmol}$ ) according to the general procedure. Purification using silica gel chromatography with 3:1 hexanes:EtOAc as the eluent gave the product as a white solid (28.6 mg, 79\% yield). ${ }^{1} \mathbf{H}$ NMR $(600 \mathrm{MHz}$, $\left.\mathrm{CDCl}_{3}\right) \delta 8.53\left(\mathrm{dd}, J_{1}=4.8 \mathrm{~Hz}, J_{2}=0.9 \mathrm{~Hz}, 1 \mathrm{H}\right), 8.18(\mathrm{~d}, J=7.8 \mathrm{~Hz}, 1 \mathrm{H})$, $8.07(\mathrm{~s}, 1 \mathrm{H}), 7.84\left(\mathrm{td}, J_{1}=7.7 \mathrm{~Hz}, J_{2}=1.7 \mathrm{~Hz}, 1 \mathrm{H}\right), 7.42\left(\mathrm{ddd}, J_{1}=7.6 \mathrm{~Hz}, J_{2}=4.8 \mathrm{~Hz}, J_{3}=1.3\right.$ $\mathrm{Hz}, 1 \mathrm{H}), 7.32-7.29(\mathrm{~m}, 2 \mathrm{H}), 7.28-7.26(\mathrm{~m}, 1 \mathrm{H}), 7.26-7.21(\mathrm{~m}, 2 \mathrm{H}), 7.21-7.18(\mathrm{~m}, 2 \mathrm{H})$, $7.12-7.08(\mathrm{~m}, 2 \mathrm{H}), 6.14(\mathrm{t}, J=7.5 \mathrm{~Hz}, 1 \mathrm{H}), 3.61-3.55(\mathrm{~m}, 2 \mathrm{H}), 2.45(\mathrm{q}, J=7.1 \mathrm{~Hz}, 2 \mathrm{H}) ;{ }^{13} \mathbf{C}$ NMR $\left(150 \mathrm{MHz}, \mathrm{CDCl}_{3}\right) \delta 164.21,149.85,147.97,143.02,141.83,138.16,137.34,133.05$, $131.19,128.51,128.20,127.32,127.22,126.29,126.11,122.18,39.14,30.18$; HRMS (ESI-TOF) Calcd for $\mathrm{C}_{22} \mathrm{H}_{19} \mathrm{ClN}_{2} \mathrm{O}^{+}[\mathrm{M}+\mathrm{H}]^{+} 363.1259$, found 363.1258.

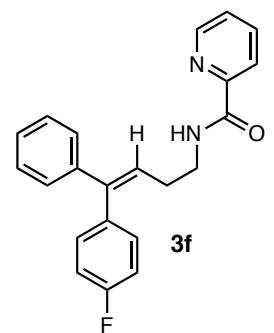

(Z)-N-(4-(4-fluorophenyl)-4-phenylbut-3-en-1-yl)picolinamide (3f): The title compound was prepared from $\mathbf{1 f}(26.8 \mathrm{mg}, 0.1 \mathrm{mmol})$ and phenyl boronic acid (22 $\mathrm{mg}, 0.18 \mathrm{mmol}$ ) according to the general procedure. Purification using silica gel chromatography with 3:1 hexanes:EtOAc as the eluent gave the product as a white solid (24.5 $\mathrm{mg}, 71 \%$ yield). ${ }^{1} \mathbf{H}$ NMR $(600 \mathrm{MHz}$, $\left.\mathrm{CDCl}_{3}\right) \delta 8.53-8.51(\mathrm{~m}, 1 \mathrm{H}), 8.19(\mathrm{~d}, J=7.8 \mathrm{~Hz}, 1 \mathrm{H}), 8.08(\mathrm{bs}, 1 \mathrm{H}), 7.84(\mathrm{td}$, $\left.J_{1}=7.7 \mathrm{~Hz}, J_{2}=1.7 \mathrm{~Hz}, 1 \mathrm{H}\right), 7.41\left(\mathrm{ddd}, J_{1}=7.6 \mathrm{~Hz}, J_{2}=4.8 \mathrm{~Hz}, J_{3}=1.2 \mathrm{~Hz}, 1 \mathrm{H}\right), 7.27-7.19$ $(\mathrm{m}, 5 \mathrm{H}), 7.15-7.11(\mathrm{~m}, 2 \mathrm{H}), 7.04-6.99(\mathrm{~m}, 2 \mathrm{H}), 6.13(\mathrm{t}, J=7.5 \mathrm{~Hz}, 1 \mathrm{H}), 3.58(\mathrm{q}, J=6.7 \mathrm{~Hz}$, 
2H), $2.45(\mathrm{q}, J=7.1 \mathrm{~Hz}, 2 \mathrm{H}) ;{ }^{13} \mathbf{C}$ NMR $\left(125 \mathrm{MHz}, \mathrm{CDCl}_{3}\right) \delta 164.19,161.92\left(\mathrm{~d}, J_{C-F}=246.2\right.$ $\mathrm{Hz}), 149.87,147.95,143.13,142.10,137.32,135.54,131.40$ (d, $\left.J_{C-F}=8.0 \mathrm{~Hz}\right), 128.15,127.23$, 127.19, 126.11, 126.08, 122.16, $115.20\left(\mathrm{~d}, J_{C-F}=21.3 \mathrm{~Hz}\right.$ ), 39.17, 30.15; HRMS (ESI-TOF) Calcd for $\mathrm{C}_{22} \mathrm{H}_{20} \mathrm{FN}_{2} \mathrm{O}^{+}[\mathrm{M}+\mathrm{H}]^{+}$347.1554, found 347.1552.

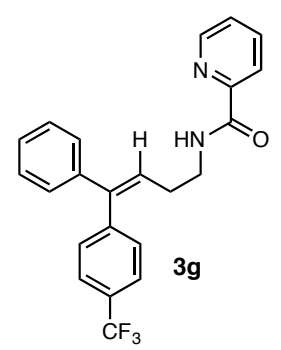

(Z)-N-(4-phenyl-4-(4-(trifluoromethyl)phenyl)but-3-en-1-yl)picolinamide (3g): The title compound was prepared from $1 \mathrm{~g}(31.8 \mathrm{mg}, 0.1 \mathrm{mmol})$ and phenylboronic acid (22 $\mathrm{mg}, 0.18 \mathrm{mmol}$ ) according to the general procedure. Purification using silica gel chromatography with $3: 1$ hexanes:EtOAc as the eluent gave the product as a white solid $\left(26.5 \mathrm{mg}, 67 \%\right.$ yield). ${ }^{1} \mathbf{H}$ NMR $(600$ $\left.\mathrm{MHz}, \mathrm{CDCl}_{3}\right) \delta 8.53$ (ddd, $\left.J_{1}=4.8 \mathrm{~Hz}, J_{2}=1.7 \mathrm{~Hz}, J_{3}=0.9 \mathrm{~Hz}, 1 \mathrm{H}\right), 8.18(\mathrm{dt}$, $\left.J_{I}=7.8 \mathrm{~Hz}, J_{2}=1.1 \mathrm{~Hz}, 1 \mathrm{H}\right), 8.07(\mathrm{bs}, 1 \mathrm{H}), 7.84\left(\mathrm{td}, J_{1}=7.7 \mathrm{~Hz}, J_{2}=1.7 \mathrm{~Hz}\right.$,

$1 \mathrm{H}), 7.58(\mathrm{~d}, J=8.3 \mathrm{~Hz}, 2 \mathrm{H}), 7.42\left(\mathrm{ddd}, J_{1}=7.6 \mathrm{~Hz}, J_{2}=4.8 \mathrm{~Hz}, J_{3}=1.2 \mathrm{~Hz}, 1 \mathrm{H}\right), 7.30-7.24$ (m, 5H), 7.20-7.17 (m, 2H), 6.19 (t, $J=7.6 \mathrm{~Hz}, 1 \mathrm{H}), 3.59$ (q, $J=6.9 \mathrm{~Hz}, 2 \mathrm{H}), 2.44$ (q, $J=7.1$ $\mathrm{Hz}, 2 \mathrm{H}) ;{ }^{13} \mathrm{C}$ NMR $\left(150 \mathrm{MHz}, \mathrm{CDCl}_{3}\right) \delta 164.22,149.82,147.97,143.57,142.94,141.47$, $137.37,130.18,129.31$ (q, $J=32.5 \mathrm{~Hz}), 128.28,127.46,127.20,126.82,126.14,125.26$ (q, $J=$ $3.7 \mathrm{~Hz}$ ), $124.17(\mathrm{q}, J=272.0 \mathrm{~Hz}), 122.20,39.07,30.20$; HRMS (ESI-TOF) Calcd for $\mathrm{C}_{23} \mathrm{H}_{20} \mathrm{~F}_{3} \mathrm{~N}_{2} \mathrm{O}^{+}[\mathrm{M}+\mathrm{H}]^{+}$397.1522, found 397.1524.

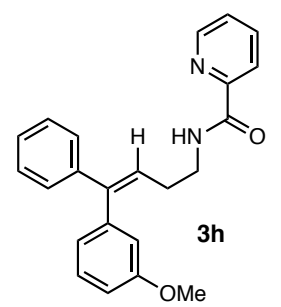

(Z)-N-(4-(3-methoxyphenyl)-4-phenylbut-3-en-1-yl)picolinamide (3h): The title compound was prepared from $1 \mathbf{h}(28 \mathrm{mg}, 0.1 \mathrm{mmol})$ and phenylboronic acid (22 $\mathrm{mg}, 0.18 \mathrm{mmol}$ ) according to the general procedure. Purification using silica gel chromatography with 3:1 hexane:EtOAc as the eluent gave the product as a colorless oil (30.1 mg, 84\% yield). ${ }^{1} \mathbf{H}$ NMR $\left(600 \mathrm{MHz}, \mathrm{CDCl}_{3}\right) \delta$ $8.52\left(\mathrm{ddd}, J_{1}=4.8 \mathrm{~Hz}, J_{2}=1.7 \mathrm{~Hz}, J_{3}=0.9 \mathrm{~Hz}, 1 \mathrm{H}\right), 8.18(\mathrm{~d}, J=7.8 \mathrm{~Hz}, 1 \mathrm{H})$, $8.08(\mathrm{bs}, 1 \mathrm{H}), 7.83\left(\mathrm{td}, J_{1}=7.7 \mathrm{~Hz}, J_{2}=1.7 \mathrm{~Hz}, 1 \mathrm{H}\right), 7.40\left(\mathrm{ddd}, J_{1}=7.6 \mathrm{~Hz}, J_{2}=4.8 \mathrm{~Hz}, J_{3}=1.2\right.$ $\mathrm{Hz}, 1 \mathrm{H}), 7.26-7.19(\mathrm{~m}, 6 \mathrm{H}), 6.85\left(\mathrm{ddd}, J_{1}=8.3 \mathrm{~Hz}, J_{2}=2.6 \mathrm{~Hz}, J_{3}=1.0 \mathrm{~Hz}, 1 \mathrm{H}\right), 6.79-6.74(\mathrm{~m}$, $1 \mathrm{H}), 6.71\left(\mathrm{dd}, J_{1}=2.7 \mathrm{~Hz}, J_{2}=1.5 \mathrm{~Hz}, 1 \mathrm{H}\right), 6.13(\mathrm{t}, J=7.4 \mathrm{~Hz}, 1 \mathrm{H}), 3.75(\mathrm{~s}, 3 \mathrm{H}), 3.58(\mathrm{q}, J=$ $6.9 \mathrm{~Hz}, 2 \mathrm{H}), 2.47$ (q, $J=7.1 \mathrm{~Hz}, 2 \mathrm{H}) ;{ }^{13} \mathbf{C}$ NMR $\left(150 \mathrm{MHz}, \mathrm{CDCl}_{3}\right) \delta 164.21,159.51,149.89$, 147.97, 143.96, 141.91, 141.13, 137.28, 129.26, 128.09, 127.11, 126.03, 125.63, 122.24, 122.14, 115.25, 112.60, 55.13, 39.22, 30.12; HRMS (ESI-TOF) Calcd for $\mathrm{C}_{23} \mathrm{H}_{23} \mathrm{~N}_{2} \mathrm{O}_{2}{ }^{+}[\mathrm{M}+\mathrm{H}]^{+}$ 359.1754 , found 359.1754 .

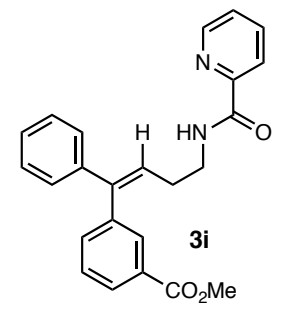

Methyl (Z)-3-(1-phenyl-4-(picolinamido)but-1-en-1-yl)benzoate (3i): The title compound was prepared from $1 \mathbf{i}(30.8 \mathrm{mg}, 0.1 \mathrm{mmol})$ and phenylboronic acid $(22 \mathrm{mg}, 0.18 \mathrm{mmol}$ ) according to the general procedure. Purification using silica gel chromatography with 3:1 hexanes:EtOAc as the eluent gave the product as a colorless oil (27.4 $\mathrm{mg}, 71 \%$ yield). ${ }^{1} \mathbf{H}$ NMR $\left(600 \mathrm{MHz}, \mathrm{CDCl}_{3}\right) \delta$ 
$8.52\left(\mathrm{dd}, J_{1}=4.7 \mathrm{~Hz}, J_{2}=1.6 \mathrm{~Hz}, 1 \mathrm{H}\right), 8.21-8.14(\mathrm{~m}, 1 \mathrm{H}), 8.08(\mathrm{bs}, 1 \mathrm{H}), 7.99\left(\mathrm{dt}, J_{1}=7.7 \mathrm{~Hz}, J_{2}\right.$ $=1.5 \mathrm{~Hz}, 1 \mathrm{H}), 7.88-7.78(\mathrm{~m}, 2 \mathrm{H}), 7.44-7.35(\mathrm{~m}, 3 \mathrm{H}), 7.28-7.19(\mathrm{~m}, 4 \mathrm{H}), 6.18(\mathrm{t}, J=7.5 \mathrm{~Hz}$, 1H), $3.87(\mathrm{~s}, 3 \mathrm{H}), 3.58(\mathrm{q}, J=6.7 \mathrm{~Hz}, 2 \mathrm{H}), 2.44$ (q, $J=7.2 \mathrm{~Hz}, 2 \mathrm{H}) ;{ }^{13} \mathbf{C}$ NMR (125 MHz, CDCl3) $\delta 166.91,164.20,149.81,147.99,143.21,141.73,140.05,137.27,134.38,130.76$, $130.32,128.41,128.20,127.30,127.21,126.49,126.04,122.12,52.08,39.10,30.13$; HRMS (ESI-TOF) Calcd for $\mathrm{C}_{24} \mathrm{H}_{23} \mathrm{~N}_{2} \mathrm{O}_{3}{ }^{+}[\mathrm{M}+\mathrm{H}]^{+}$387.1703, found 387.1703.

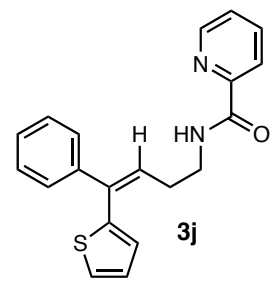

(Z)-N-(4-phenyl-4-(thiophen-2-yl)but-3-en-1-yl)picolinamide (3j): The title compound was prepared from $\mathbf{1 j} \mathbf{j}(25.6 \mathrm{mg}, 0.1 \mathrm{mmol})$ and phenylboronic acid (22 $\mathrm{mg}, 0.18 \mathrm{mmol}$ ) according to the general procedure. Purification using silica gel chromatography with 3:1 hexanes:EtOAc as the eluent gave the product as a white powder (18.4 mg, 55\% yield). ${ }^{1} \mathbf{H}$ NMR $\left(600 \mathrm{MHz}, \mathrm{CDCl}_{3}\right)$ $\delta 8.53\left(\mathrm{ddd}, J_{1}=4.8 \mathrm{~Hz}, J_{2}=1.7 \mathrm{~Hz}, J_{3}=1.0 \mathrm{~Hz}, 1 \mathrm{H}\right), 8.20\left(\mathrm{dt}, J_{1}=7.8 \mathrm{~Hz}, J_{2}\right.$ $=1.1 \mathrm{~Hz}, 1 \mathrm{H}), 8.14(\mathrm{bs}, 1 \mathrm{H}), 7.84\left(\mathrm{td}, J_{1}=7.7 \mathrm{~Hz}, J_{2}=1.7 \mathrm{~Hz}, 1 \mathrm{H}\right), 7.41\left(\mathrm{ddd}, J_{1}=7.6 \mathrm{~Hz}, J_{2}=\right.$ $\left.4.8 \mathrm{~Hz}, J_{3}=1.3 \mathrm{~Hz}, 1 \mathrm{H}\right), 7.35-7.26(\mathrm{~m}, 6 \mathrm{H}), 7.03\left(\mathrm{dd}, J_{1}=5.1 \mathrm{~Hz}, J_{2}=3.5 \mathrm{~Hz}, 1 \mathrm{H}\right), 6.93\left(\mathrm{dd}, J_{1}\right.$ $\left.=3.5 \mathrm{~Hz}, J_{2}=1.2 \mathrm{~Hz}, 1 \mathrm{H}\right), 6.07(\mathrm{t}, J=7.4 \mathrm{~Hz}, 1 \mathrm{H}), 3.64\left(\mathrm{td}, J_{l}=7.0 \mathrm{~Hz}, J_{2}=6.0 \mathrm{~Hz}, 2 \mathrm{H}\right), 2.68$ $(\mathrm{q}, J=7.2 \mathrm{~Hz}, 2 \mathrm{H}) ;{ }^{13} \mathbf{C} \mathbf{N M R}\left(150 \mathrm{MHz}, \mathrm{CDCl}_{3}\right) \delta 164.31,149.89,148.00,142.59,141.01$, $137.30,137.04,128.48,128.09,127.90,127.53,127.46,126.79,126.08,125.75,122.17,39.24$, 30.46; HRMS (ESI-TOF) Calcd for $\mathrm{C}_{20} \mathrm{H}_{19} \mathrm{~N}_{2} \mathrm{OS}^{+}[\mathrm{M}+\mathrm{H}]^{+} 335.1213$, found 335.1204.

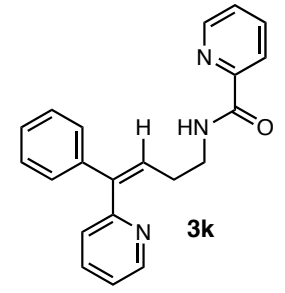

(Z)-N-(4-phenyl-4-(pyridin-2-yl)but-3-en-1-yl)picolinamide (3k): The title compound was prepared from $1 \mathbf{k}(25.1 \mathrm{mg}, 0.1 \mathrm{mmol})$, phenylboronic acid (22 $\mathrm{mg}, 0.18 \mathrm{mmol}$ ), and $\mathrm{PCy}_{3} \cdot \mathrm{HBF}_{4}(3.7 \mathrm{mg}, 10 \mathrm{~mol} \%)$ under conditions otherwise identical to those described in the general procedure. Purification using silica gel chromatography with 1:1 hexanes:EtOAc as the eluent gave the product as a white powder (8.3 mg, $25 \%$ yield). ${ }^{1} \mathbf{H} \mathbf{~ N M R}\left(600 \mathrm{MHz}, \mathrm{CDCl}_{3}\right) \delta$ 8.83 (bs, $1 \mathrm{H}), 8.74-8.73(\mathrm{~m}, 1 \mathrm{H}), 8.56-8.55(\mathrm{~m}, 1 \mathrm{H}), 8.18$ (d, $J=7.8 \mathrm{~Hz}, 1 \mathrm{H}), 7.83\left(\mathrm{td}, J_{1}=7.7\right.$ $\left.\mathrm{Hz}, J_{2}=1.7 \mathrm{~Hz}, 1 \mathrm{H}\right), 7.65\left(\mathrm{td}, J_{1}=7.7 \mathrm{~Hz}, J_{2}=1.9 \mathrm{~Hz}, 1 \mathrm{H}\right), 7.40\left(\mathrm{ddd}, J_{1}=7.6 \mathrm{~Hz}, J_{2}=4.7 \mathrm{~Hz}\right.$, $\left.J_{3}=1.2 \mathrm{~Hz}, 1 \mathrm{H}\right), 7.29-7.22(\mathrm{~m}, 6 \mathrm{H}), 7.17(\mathrm{~d}, J=7.8 \mathrm{~Hz}, 1 \mathrm{H}), 6.20(\mathrm{t}, J=7.8 \mathrm{~Hz}, 1 \mathrm{H}), 3.66(\mathrm{q}, J$ $=6.4 \mathrm{~Hz}, 2 \mathrm{H}), 2.59$ (q, $J=7.0 \mathrm{~Hz}, 2 \mathrm{H}) ;{ }^{13} \mathbf{C} \mathbf{N M R}\left(150 \mathrm{MHz}, \mathrm{CDCl}_{3}\right) \delta 164.70,158.45,150.35$, $149.32,148.01,143.42,141.52,137.16,136.15,129.01,128.23,127.55,127.34,125.88,125.04$, 122.21, 122.04, 39.49, 29.42; HRMS (ESI-TOF) Calcd for $\mathrm{C}_{21} \mathrm{H}_{20} \mathrm{~N}_{3} \mathrm{O}^{+}[\mathrm{M}+\mathrm{H}]^{+} 330.1601$, found 330.1600 . 


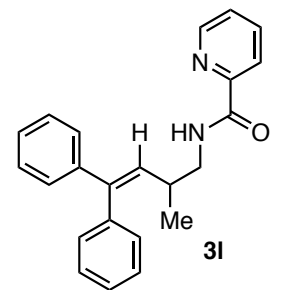

N-(2-methyl-4,4-diphenylbut-3-en-1-yl)picolinamide (31): The title compound was prepared from 11 (26.4 mg, $0.1 \mathrm{mmol})$ and phenylboronic acid (22 $\mathrm{mg}, 0.18 \mathrm{mmol}$ ) according to the general procedure. Purification using silica gel chromatography with 3:1 hexanes:EtOAc as the eluent gave the product as a colorless oil (27.4 mg, 80\% yield). ${ }^{1} \mathbf{H}$ NMR $\left(600 \mathrm{MHz}, \mathrm{CDCl}_{3}\right) \delta$ $8.52\left(\mathrm{ddd}, J_{1}=4.8 \mathrm{~Hz}, J_{2}=1.8, J_{3}=0.9 \mathrm{~Hz}, 1 \mathrm{H}\right), 8.17\left(\mathrm{dt}, J_{l}=7.8 \mathrm{~Hz}, J_{2}=1.1\right.$ $\mathrm{Hz}, 1 \mathrm{H}), 8.04(\mathrm{bs}, 1 \mathrm{H}), 7.82\left(\mathrm{td}, J_{l}=7.7 \mathrm{~Hz}, J_{2}=1.7 \mathrm{~Hz}, 1 \mathrm{H}\right), 7.39$ (ddd, $J_{1}=7.5 \mathrm{~Hz}, J_{2}=4.8$ $\left.\mathrm{Hz}, J_{3}=1.2 \mathrm{~Hz}, 1 \mathrm{H}\right), 7.32-7.20(\mathrm{~m}, 8 \mathrm{H}), 7.15-7.13(\mathrm{~m}, 2 \mathrm{H}), 5.94(\mathrm{~d}, J=10.3 \mathrm{~Hz}, 1 \mathrm{H})$, 3.53-3.48 (m, 1H), 3.39-3.33 (m, 1H), 2.66-2.60 (m, 1H), $1.12(\mathrm{~d}, J=6.7 \mathrm{~Hz}, 3 \mathrm{H})$; ${ }^{13} \mathbf{C}$ NMR $\left(150 \mathrm{MHz}, \mathrm{CDCl}_{3}\right) \delta 164.06,149.96,147.92,142.86,142.10,139.96,137.23,132.30,129.61$, 128.24, 128.08, 127.15, 127.08, 127.00, 125.97, 122.15, 45.09, 34.75, 18.73; HRMS (ESI-TOF) Calcd for $\mathrm{C}_{23} \mathrm{H}_{23} \mathrm{~N}_{2} \mathrm{O}^{+}[\mathrm{M}+\mathrm{H}]^{+}$343.1805, found 343.1802.

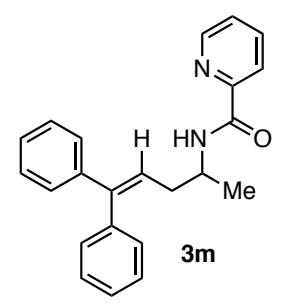

$\boldsymbol{N}$-(5,5-diphenylpent-4-en-2-yl)picolinamide (3m): The title compound was prepared from $1 \mathrm{~m}(26.4 \mathrm{mg}, 0.1 \mathrm{mmol})$ and phenylboronic acid (22 $\mathrm{mg}, 0.18$ mmol) according to the general procedure. Purification using silica gel chromatography with 3:1 hexanes:EtOAc as the eluent gave the product as a white solid (25.7 mg, 75\% yield). ${ }^{1} \mathbf{H}$ NMR (500 $\left.\mathrm{MHz}, \mathrm{CDCl}_{3}\right) \delta 8.53-8.51$ $(\mathrm{m}, 1 \mathrm{H}), 8.19(\mathrm{~d}, J=7.7 \mathrm{~Hz}, 1 \mathrm{H}), 7.90-7.81(\mathrm{~m}, 2 \mathrm{H}), 7.42-7.29(\mathrm{~m}, 4 \mathrm{H})$, $7.24-7.15(\mathrm{~m}, 7 \mathrm{H}), 6.14(\mathrm{t}, J=7.4 \mathrm{~Hz}, 1 \mathrm{H}), 4.34\left(\mathrm{dd}, J_{1}=8.8 \mathrm{~Hz}, J_{2}=6.6 \mathrm{~Hz}, 1 \mathrm{H}\right), 2.43\left(\mathrm{td}, J_{1}=\right.$ $\left.7.1 \mathrm{~Hz}, J_{2}=2.8 \mathrm{~Hz}, 2 \mathrm{H}\right), 1.26(\mathrm{~d}, J=6.6 \mathrm{~Hz}, 3 \mathrm{H}) ;{ }^{13} \mathbf{C} \mathbf{N M R}(125 \mathrm{MHz},) \delta 163.50,150.03$, $147.89,143.94,142.38,139.91,137.29,129.90,128.22,128.06,127.24,127.02,125.99,125.39$, 122.17, 45.52, 36.94, 20.71; HRMS (ESI-TOF) Calcd for $\mathrm{C}_{23} \mathrm{H}_{23} \mathrm{~N}_{2} \mathrm{O}^{+}[\mathrm{M}+\mathrm{H}]^{+} 343.1805$, found 343.1806 .

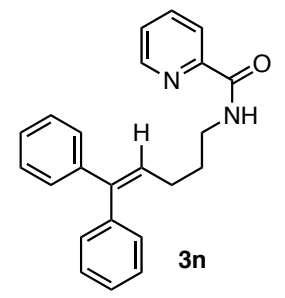

$\boldsymbol{N}$-(5,5-diphenylpent-4-en-1-yl)picolinamide (3n): The title compound was prepared from 1n $(26.4 \mathrm{mg}, 0.1 \mathrm{mmol})$ and phenylboronic acid (22 $\mathrm{mg}, 0.18$ $\mathrm{mmol}$ ) according to the general procedure. Purification using silica gel chromatography with 3:1 hexanes:EtOAc as the eluent gave the product as a pale yellow oil (23.9 mg, 70\% yield). ${ }^{1} \mathbf{H} \mathbf{~ N M R}\left(600 \mathrm{MHz}, \mathrm{CDCl}_{3}\right) \delta 8.49-8.48$ $(\mathrm{m}, 1 \mathrm{H}), 8.18(\mathrm{~d}, J=7.8 \mathrm{~Hz}, 1 \mathrm{H}), 8.03(\mathrm{bs}, 1 \mathrm{H}), 7.83\left(\mathrm{td}, J_{1}=7.7 \mathrm{~Hz}, J_{2}=1.7\right.$ $\mathrm{Hz}, 1 \mathrm{H}), 7.40\left(\mathrm{ddd}, J_{1}=7.6 \mathrm{~Hz}, J_{2}=4.8 \mathrm{~Hz}, J_{3}=1.3 \mathrm{~Hz}, 1 \mathrm{H}\right), 7.34-7.32(\mathrm{~m}, 2 \mathrm{H}), 7.28-7.16(\mathrm{~m}$, $8 \mathrm{H}), 6.12(\mathrm{t}, J=7.5 \mathrm{~Hz}, 1 \mathrm{H}), 3.46\left(\mathrm{td}, J_{l}=7.2 \mathrm{~Hz}, J_{2}=6.2 \mathrm{~Hz}, 2 \mathrm{H}\right), 2.24(\mathrm{q}, J=7.5 \mathrm{~Hz}, 2 \mathrm{H})$, $1.79(\mathrm{p}, J=7.2 \mathrm{~Hz}, 2 \mathrm{H}) ;{ }^{13} \mathbf{C} \mathbf{N M R}(150 \mathrm{MHz}$ ) $\delta 164.16,149.95,147.91,142.49,142.45$, $139.95,137.24,129.77,128.53,128.20,128.04,127.15,126.89,125.97,122.08,38.97,29.75$, 27.25; HRMS (ESI-TOF) Calcd for $\mathrm{C}_{23} \mathrm{H}_{23} \mathrm{~N}_{2} \mathrm{O}^{+}[\mathrm{M}+\mathrm{H}]^{+} 343.1805$, found 343.1805. 


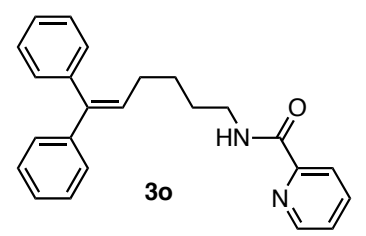

$N$-(6,6-diphenylhex-5-en-1-yl)picolinamide (30): The title compound was prepared from $10(27.8 \mathrm{mg}, 0.1 \mathrm{mmol})$, and phenylboronic acid (22 $\mathrm{mg}, 0.18 \mathrm{mmol})$ according to the general procedure. Purification using silica gel chromatography with 3:1 hexanes:EtOAc as the eluent gave the product as a yellow oil $\left(27 \mathrm{mg}, 76 \%\right.$ yield). ${ }^{1} \mathbf{H}$ NMR $\left(600 \mathrm{MHz}, \mathrm{CDCl}_{3}\right)$ $\delta 8.54-8.53(\mathrm{~m}, 1 \mathrm{H}), 8.19\left(\mathrm{~d}, J_{l}=7.9 \mathrm{~Hz}, 1 \mathrm{H}\right), 8.04(\mathrm{bs}, 1 \mathrm{H}), 7.83\left(\mathrm{td}, J_{l}=7.7 \mathrm{~Hz}, J_{2}=1.8 \mathrm{~Hz}\right.$, $1 \mathrm{H}), 7.41\left(\mathrm{ddd}, J_{1}=7.5 \mathrm{~Hz}, J_{2}=4.7 \mathrm{~Hz}, J_{3}=1.2 \mathrm{~Hz}, 1 \mathrm{H}\right), 7.37-7.23(\mathrm{~m}, 6 \mathrm{H}), 7.22-7.16(\mathrm{~m}$, $4 \mathrm{H}), 6.08$ (t, $J=7.4 \mathrm{~Hz}, 1 \mathrm{H}), 3.43$ (q, $J=6.8 \mathrm{~Hz}, 2 \mathrm{H}), 2.17$ (q, $J=7.4 \mathrm{~Hz}, 2 \mathrm{H}) 1.66-1.62(\mathrm{~m}$, 2H), 1.58-1.53 (m, 2H); ${ }^{13}$ C NMR (150 MHz, $\left.\mathrm{CDCl}_{3}\right) \delta 164.17,149.98,147.95,142.62,141.94$, $140.09,137.29,129.82,129.36,128.13,128.02,127.14,126.87,126.79,126.00,122.14,39.22$, 29.34, 29.28, 27.29; HRMS (ESI-TOF) Calcd for $\mathrm{C}_{24} \mathrm{H}_{25} \mathrm{~N}_{2} \mathrm{O}^{+}[\mathrm{M}+\mathrm{H}]^{+}$357.1961, found 357.1963 .

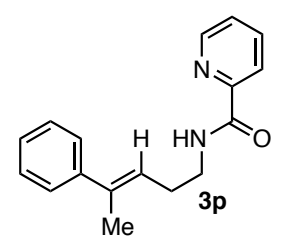

(E)- $\mathrm{N}$-(4-phenylpent-3-en-1-yl)picolinamide (3p): The title compound was prepared from 1p (18.8 mg, $0.1 \mathrm{mmol})$ and phenylboronic acid (22 $\mathrm{mg}, 0.18$ mmol) according to the general procedure. Purification using silica gel chromatography with 3:1 hexanes:EtOAc as the eluent gave the product as a colorless solid (14.6 mg, 55\% yield). ${ }^{1} \mathbf{H}$ NMR (600 MHz, $\left.\mathrm{CDCl}_{3}\right) \delta 8.54$ (ddd, $\left.J_{1}=4.8 \mathrm{~Hz}, J_{2}=1.8 \mathrm{~Hz}, J_{3}=0.9 \mathrm{~Hz}, 1 \mathrm{H}\right), 8.22-8.10(\mathrm{~m}, 2 \mathrm{H}), 7.84\left(\mathrm{td}, J_{1}=7.7 \mathrm{~Hz}, J_{2}=1.8 \mathrm{~Hz}\right.$, $1 \mathrm{H}), 7.43-7.38(\mathrm{~m}, 3 \mathrm{H}), 7.31\left(\mathrm{dd}, J_{1}=8.4 \mathrm{~Hz}, J_{2}=6.9 \mathrm{~Hz}, 2 \mathrm{H}\right), 7.25-7.22(\mathrm{~m}, 1 \mathrm{H}), 5.82\left(\mathrm{tq}, J_{1}=\right.$ $\left.7.3 \mathrm{~Hz}, J_{2}=1.4 \mathrm{~Hz}, 1 \mathrm{H}\right), 3.61\left(\mathrm{td}, J_{1}=7.1 \mathrm{~Hz}, J_{2}=6.0 \mathrm{~Hz}, 2 \mathrm{H}\right), 2.58-2.55(\mathrm{~m}, 2 \mathrm{H}), 2.07-2.06$ $(\mathrm{m}, 3 \mathrm{H}) ;{ }^{13} \mathbf{C}$ NMR $\left(150 \mathrm{MHz}, \mathrm{CDCl}_{3}\right) \delta 164.32,149.97,148.03,143.59,137.59,137.31$, 128.19, 126.81, 126.05, 125.72, 124.28, 122.16, 39.12, 29.10, 16.04; HRMS (ESI-TOF) Calcd for $\mathrm{C}_{17} \mathrm{H}_{18} \mathrm{~N}_{2} \mathrm{O}^{+}[\mathrm{M}+\mathrm{H}]^{+}$267.1492, found 267.1491.

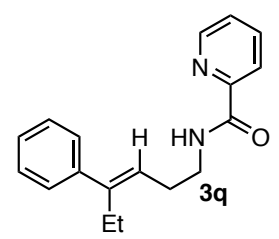

(E)- $N$-(4-phenylhex-3-en-1-yl)picolinamide (3q): The title compound was prepared from 1q $(20.2 \mathrm{mg}, 0.1 \mathrm{mmol})$, phenylboronic acid $(22 \mathrm{mg}, 0.18$ $\mathrm{mmol}), \mathrm{PPh}_{3}\left(0.7 \mathrm{mg}, 5 \mathrm{~mol} \%\right.$ ), and $\mathrm{K}_{2} \mathrm{HPO}_{4}(8.7 \mathrm{mg}, 0.1 \mathrm{mmol})$ under conditions otherwise identical to those described in the general procedure. The reaction was run for $12 \mathrm{~h}$. Purification using silica gel chromatography with 3:1 hexanes:EtOAc as the eluent gave the product as a colorless solid (10.4 mg, 37\% yield). ${ }^{1} \mathbf{H}$ NMR $\left(600 \mathrm{MHz}, \mathrm{CDCl}_{3}\right) \delta 8.53\left(\mathrm{ddd}, J_{l}=4.8 \mathrm{~Hz}, J_{2}=1.8, J_{3}=0.9 \mathrm{~Hz}, 1 \mathrm{H}\right), 8.22-8.18(\mathrm{~m}, 2 \mathrm{H})$, $7.84\left(\mathrm{td}, J_{1}=7.7 \mathrm{~Hz}, J_{2}=1.7 \mathrm{~Hz}, 1 \mathrm{H}\right), 7.41\left(\mathrm{ddd}, J_{1}=7.6 \mathrm{~Hz}, J_{2}=4.8, J_{3}=1.2 \mathrm{~Hz}, 1 \mathrm{H}\right)$, $7.36-7.30(\mathrm{~m}, 4 \mathrm{H}), 7.25-7.22(\mathrm{~m}, 1 \mathrm{H}), 5.66(\mathrm{t}, J=7.4 \mathrm{~Hz}, 1 \mathrm{H}), 3.59\left(\mathrm{td}, J_{1}=7.1 \mathrm{~Hz}, J_{2}=6.1\right.$ $\mathrm{Hz}, 2 \mathrm{H}), 2.55\left(\mathrm{dq}, J_{l}=15.1 \mathrm{~Hz}, J_{2}=7.4 \mathrm{~Hz}, 4 \mathrm{H}\right), 0.96(\mathrm{t}, J=7.5 \mathrm{~Hz}, 3 \mathrm{H}) ;{ }^{13} \mathbf{C} \mathbf{N M R}(150 \mathrm{MHz}$, $\left.\mathrm{CDCl}_{3}\right) \delta 164.30,149.98,148.01,144.50,142.67,137.30,128.18,126.75,126.40,126.05$, 123.95, 122.14, 39.33, 28.75, 23.07, 13.52; HRMS (ESI-TOF) Calcd for $\mathrm{C}_{18} \mathrm{H}_{20} \mathrm{~N}_{2} \mathrm{O}^{+}[\mathrm{M}+\mathrm{H}]^{+}$ 281.1648 , found 281.1645 . 


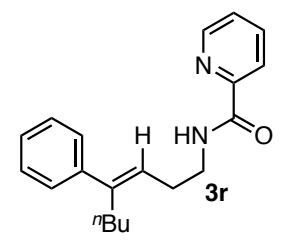

(E)- $N$-(4-phenyloct-3-en-1-yl)picolinamide (3r): The title compound was prepared from $1 \mathbf{r}(23 \mathrm{mg}, 0.1 \mathrm{mmol})$, phenylboronic acid ( $22 \mathrm{mg}, 0.18 \mathrm{mmol})$, $\mathrm{PPh}_{3}(0.7 \mathrm{mg}, 5 \mathrm{~mol} \%)$, and $\mathrm{K}_{2} \mathrm{HPO}_{4}(8.7 \mathrm{mg}, 0.1 \mathrm{mmol})$ under conditions otherwise identical to those described in the general procedure. The reaction was run for $12 \mathrm{~h}$. Purification using silica gel chromatography with 3:1 hexanes:EtOAc as the eluent gave the product as a colorless oil (13.9 mg, $45 \%$ yield). ${ }^{1} \mathbf{H}$ NMR $\left(600 \mathrm{MHz}, \mathrm{CDCl}_{3}\right) \delta 8.54-8.53(\mathrm{~m}, 1 \mathrm{H}), 8.21(\mathrm{~d}, J=7.9 \mathrm{~Hz}, 1 \mathrm{H}), 8.18(\mathrm{bs}, 1 \mathrm{H}), 7.84\left(\mathrm{td}, J_{l}=7.7\right.$ $\left.\mathrm{Hz}, J_{2}=1.7 \mathrm{~Hz}, 1 \mathrm{H}\right), 7.41\left(\mathrm{ddd}, J_{1}=7.6 \mathrm{~Hz}, J_{2}=4.8, J_{3}=1.3 \mathrm{~Hz}, 1 \mathrm{H}\right), 7.35-7.29(\mathrm{~m}, 4 \mathrm{H})$, $7.25-7.22(\mathrm{~m}, 1 \mathrm{H}), 5.66(\mathrm{t}, J=7.3 \mathrm{~Hz}, 1 \mathrm{H}), 3.60\left(\mathrm{td}, J_{1}=7.0 \mathrm{~Hz}, J_{2}=6.0 \mathrm{~Hz}, 2 \mathrm{H}\right), 2.56(\mathrm{q}, J=$ $7.1 \mathrm{~Hz}, 2 \mathrm{H}), 2.51(\mathrm{t}, J=7.3 \mathrm{~Hz}, 2 \mathrm{H}), 1.32-1.24(\mathrm{~m}, 4 \mathrm{H}), 0.80(\mathrm{t}, J=7.0 \mathrm{~Hz}, 3 \mathrm{H}) ;{ }^{13} \mathbf{C}$ NMR $(150$ $\left.\mathrm{MHz}, \mathrm{CDCl}_{3}\right) \delta 164.26,149.98,147.99,143.13,143.04,137.29,128.16,126.71,126.42,126.03$, 124.64, 122.14, 39.31, 30.84, 29.69, 28.88, 22.65, 13.91; HRMS (ESI-TOF) Calcd for $\mathrm{C}_{20} \mathrm{H}_{25} \mathrm{~N}_{2} \mathrm{O}^{+}[\mathrm{M}+\mathrm{H}]^{+}$309.1961, found 309.1960.

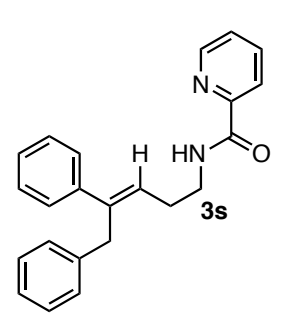

(E)- $N$-(4,5-diphenylpent-3-en-1-yl)picolinamide (3s): The title compound was prepared from $1 \mathrm{~s}(26.4 \mathrm{mg}, 0.1 \mathrm{mmol})$, phenylboronic acid $(22 \mathrm{mg}, 0.18$ $\mathrm{mmol}), \mathrm{PPh}_{3}\left(0.7 \mathrm{mg}, 5 \mathrm{~mol} \%\right.$ ), and $\mathrm{K}_{2} \mathrm{HPO}_{4}(8.7 \mathrm{mg}, 0.1 \mathrm{mmol})$ under conditions otherwise identical to those described in the general procedure. The reaction was run for $20 \mathrm{~h}$. Purification using silica gel chromatography with 3:1 hexanes:EtOAc as the eluent gave the product as a white solid $(9.2 \mathrm{mg}$, $27 \%$ yield). ${ }^{1} \mathbf{H}$ NMR $\left(600 \mathrm{MHz}, \mathrm{CDCl}_{3}\right) \delta 8.54(\mathrm{~d}, J=4.8 \mathrm{~Hz}, 1 \mathrm{H}), 8.20(\mathrm{~d}, J=7.8 \mathrm{~Hz}, 1 \mathrm{H})$, $8.17(\mathrm{bs}, 1 \mathrm{H}), 7.84\left(\mathrm{td}, J_{I}=7.7 \mathrm{~Hz}, J_{2}=1.8 \mathrm{~Hz}, 1 \mathrm{H}\right), 7.42\left(\mathrm{ddd}, J_{I}=7.6 \mathrm{~Hz}, J_{2}=4.7, J_{3}=1.3\right.$ $\mathrm{Hz}, 1 \mathrm{H}), 7.35-7.33(\mathrm{~m}, 2 \mathrm{H}), 7.26-7.23(\mathrm{~m}, 2 \mathrm{H}), 7.20-7.09(\mathrm{~m}, 6 \mathrm{H}), 6.01(\mathrm{t}, J=7.2 \mathrm{~Hz}, 1 \mathrm{H})$, $3.90(\mathrm{~s}, 2 \mathrm{H}), 3.63$ (q, $J=6.8 \mathrm{~Hz}, 2 \mathrm{H}), 2.61$ (q, $J=7.1 \mathrm{~Hz}, 2 \mathrm{H}) ;{ }^{13} \mathbf{C} \mathbf{N M R}\left(150 \mathrm{MHz}, \mathrm{CDCl}_{3}\right) \delta$ $164.31,149.92,148.02,142.58,140.06,139.35,137.32,128.35,128.20,128.10,126.90,126.88$, $126.35,126.08,125.86,122.18,39.15,35.90,29.38$; HRMS (ESI-TOF) Calcd for $\mathrm{C}_{23} \mathrm{H}_{23} \mathrm{~N}_{2} \mathrm{O}^{+}$ $[\mathrm{M}+\mathrm{H}]^{+} 343.1805$, found 343.1807 .

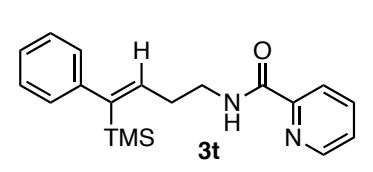

(Z)-N-(4-phenyl-4-(trimethylsilyl)but-3-en-1-yl)picolinamide (3t): The title compound was prepared from $1 \mathrm{t}(24.6 \mathrm{mg}, 0.1 \mathrm{mmol})$, phenylboronic acid $(22 \mathrm{mg}, 0.18 \mathrm{mmol})$ according to the general procedure. Purification using silica gel chromatography with $3: 1$ hexanes:EtOAc as the eluent gave the product as a colorless oil $\left(3.9 \mathrm{mg}, 12 \%\right.$ yield). ${ }^{1} \mathbf{H} \mathbf{~ N M R}\left(600 \mathrm{MHz}, \mathrm{CDCl}_{3}\right) \delta 8.55$ (ddd, $J=4.8,1.8,0.9 \mathrm{~Hz}, 1 \mathrm{H}), 8.22-8.20(\mathrm{~m}, 2 \mathrm{H}), 7.85(\mathrm{td}, J=7.7,1.7 \mathrm{~Hz}, 1 \mathrm{H}), 7.42(\mathrm{ddd}, J=7.6$, 4.8, 1.3 Hz, 1H), 7.30-7.21 (m, 2H), 7.21-7.13 (m, 1H), 7.10-6.94 (m, 2H), 6.10 (t, J = 7.5 Hz, $1 \mathrm{H}), 3.60(\mathrm{td}, J=6.9,6.0 \mathrm{~Hz}, 2 \mathrm{H}), 2.63(\mathrm{q}, J=7.1 \mathrm{~Hz}, 2 \mathrm{H}), 0.14(\mathrm{~s}, 9 \mathrm{H}) ;{ }^{13} \mathbf{C}$ NMR $(150 \mathrm{MHz}$, $\left.\mathrm{CDCl}_{3}\right) \delta 164.24,149.94,148.01,146.82,146.56,142.03,137.31,127.76,127.34,126.08$, 
125.48, 122.16, 39.18, 32.27, 0.68; HRMS (ESI-TOF) Calcd for $\mathrm{C}_{19} \mathrm{H}_{25} \mathrm{~N}_{2} \mathrm{OSi}^{+}[\mathrm{M}+\mathrm{H}]^{+}$ 325.1731 , found 325.1730 .

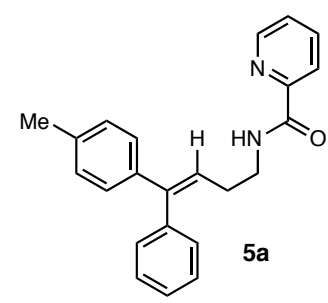

(E)- $N$-(4-phenyl-4-(p-tolyl)but-3-en-1-yl)picolinamide (5a): The title compound was prepared from 1a $(25 \mathrm{mg}, 0.1 \mathrm{mmol})$ and $p$-tolylboronic acid (24 mg, $0.18 \mathrm{mmol}$ ) according to the general procedure. Purification using silica gel chromatography with 3:1 hexanes:EtOAc as the eluent gave the product as a white solid (26.7 $\mathrm{mg}, 80 \%$ yield). ${ }^{1} \mathbf{H}$ NMR $(600 \mathrm{MHz}$, $\left.\mathrm{CDCl}_{3}\right) \delta 8.52(\mathrm{dd}, J=4.8,1.5 \mathrm{~Hz}, 1 \mathrm{H}), 8.18\left(\mathrm{dt}, J_{I}=7.8 \mathrm{~Hz}, J_{2}=1.1 \mathrm{~Hz}\right.$, $1 \mathrm{H}), 8.06(\mathrm{bs}, 1 \mathrm{H}), 7.83\left(\mathrm{td}, J_{1}=7.7 \mathrm{~Hz}, J_{2}=1.7 \mathrm{~Hz}, 1 \mathrm{H}\right), 7.42-7.39(\mathrm{~m}, 1 \mathrm{H}), 7.36-7.29(\mathrm{~m}$, $3 \mathrm{H}), 7.17-7.11(\mathrm{~m}, 4 \mathrm{H}), 7.07(\mathrm{~d}, J=8.1 \mathrm{~Hz}, 2 \mathrm{H}), 6.10(\mathrm{t}, J=7.5 \mathrm{~Hz}, 1 \mathrm{H}), 3.57$ (q, $J=6.7 \mathrm{~Hz}$, 2H), 2.44 (q, $J=7.2 \mathrm{~Hz}, 2 \mathrm{H}), 2.32(\mathrm{~s}, 3 \mathrm{H}) ;{ }^{13} \mathbf{C}$ NMR $\left(150 \mathrm{MHz}, \mathrm{CDCl}_{3}\right) \delta 164.18,149.94$, 147.95, 143.97, 139.92, 139.46, 137.27, 136.89, 129.78, 128.81, 128.21, 127.12, 127.01, 126.02, 124.78, 122.14, 39.30, 30.06, 21.04; HRMS (ESI-TOF) Calcd for $\mathrm{C}_{23} \mathrm{H}_{23} \mathrm{~N}_{2} \mathrm{O}^{+}[\mathrm{M}+\mathrm{H}]^{+}$ 343.1805 , found 343.1803 .

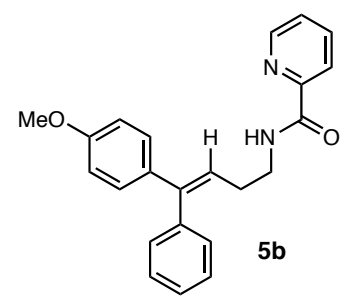

(E)-N-(4-(4-methoxyphenyl)-4-phenylbut-3-en-1-yl)picolinamide (5b): The title compound was prepared from $1 \mathrm{a}(25 \mathrm{mg}, 0.1 \mathrm{mmol})$ and $p$-methoxyphenylboronic acid $(27 \mathrm{mg}, 0.18 \mathrm{mmol}$ ) according to the general procedure. Purification using silica gel chromatography with 3:1 hexanes:EtOAc as the eluent gave the product as a colorless oil $(28 \mathrm{mg}$, $78 \%$ yield). ${ }^{1} \mathbf{H}$ NMR $\left(600 \mathrm{MHz}, \mathrm{CDCl}_{3}\right) \delta 8.50\left(\mathrm{dt}, J_{l}=4.8 \mathrm{~Hz}, J_{2}=1.3\right.$ $\mathrm{Hz}, 1 \mathrm{H}), 8.17\left(\mathrm{dt}, J_{1}=7.8 \mathrm{~Hz}, J_{2}=1.1 \mathrm{~Hz}, 1 \mathrm{H}\right), 8.09(\mathrm{bs}, 1 \mathrm{H}), 7.79\left(\mathrm{td}, J_{1}=7.7 \mathrm{~Hz}, J_{2}=1.7 \mathrm{~Hz}\right.$, $1 \mathrm{H}), 7.36\left(\mathrm{ddd}, J_{1}=7.6 \mathrm{~Hz}, J_{2}=4.8 \mathrm{~Hz}, J_{3}=1.3 \mathrm{~Hz}, 1 \mathrm{H}\right), 7.33-7.27(\mathrm{~m}, 3 \mathrm{H}), 7.17-7.14(\mathrm{~m}$, 4H), 6.79-6.78 (m, 2H), $6.04(\mathrm{t}, J=7.5 \mathrm{~Hz}, 1 \mathrm{H}), 3.75(\mathrm{~s}, 3 \mathrm{H}), 3.56$ (q, $J=6.7 \mathrm{~Hz}, 2 \mathrm{H}), 2.42(\mathrm{q}, J$ $=7.1 \mathrm{~Hz}, 2 \mathrm{H}) ;{ }^{13} \mathbf{C}$ NMR $\left(150 \mathrm{MHz}, \mathrm{CDCl}_{3}\right) \delta 164.03,158.71,149.78,147.80,143.37,139.84$, 137.11, 134.79, 129.60, 128.18, 128.07, 126.88, 125.87, 123.77, 121.95, 113.32, 55.06, 39.20, 29.93; HRMS (ESI-TOF) Calcd for $\mathrm{C}_{23} \mathrm{H}_{23} \mathrm{~N}_{2} \mathrm{O}_{2}{ }^{+}[\mathrm{M}+\mathrm{H}]^{+}$359.1754, found 359.1751.

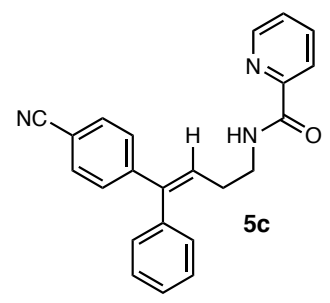

(E)-N-(4-(4-cyanophenyl)-4-phenylbut-3-en-1-yl)picolinamide (5c): The title compound was prepared from 1a $(25 \mathrm{mg}, 0.1 \mathrm{mmol})$ and $p$-cyanophenylboronic acid (26 $\mathrm{mg}, 0.18 \mathrm{mmol})$ according to the general procedure. Purification using silica gel chromatography with $3: 1$ hexanes:EtOAc as the eluent gave the product as a colorless oil $(14.2 \mathrm{mg}$, $40 \%$ yield). ${ }^{1} \mathbf{H}$ NMR $\left(600 \mathrm{MHz}, \mathrm{CDCl}_{3}\right) \delta 8.55-8.53(\mathrm{~m}, 1 \mathrm{H}), 8.19(\mathrm{~d}, J=$ $7.8 \mathrm{~Hz}, 1 \mathrm{H}), 8.07$ (bs, $1 \mathrm{H}), 7.85\left(\mathrm{td}, J_{I}=7.7 \mathrm{H}, J_{2}=1.7 \mathrm{~Hz}, 1 \mathrm{H}\right), 7.53(\mathrm{~d}, J=8.2 \mathrm{~Hz}, 2 \mathrm{H}), 7.42$ $\left(\mathrm{ddd}, J_{1}=7.5 \mathrm{~Hz}, J_{2}=4.8 \mathrm{~Hz}, J_{3}=1.3 \mathrm{~Hz}, 1 \mathrm{H}\right), 7.37-7.30(\mathrm{~m}, 5 \mathrm{H}), 7.11\left(\mathrm{dd}, J_{1}=7.5 \mathrm{~Hz}, J_{2}=\right.$ $2.0 \mathrm{~Hz}, 2 \mathrm{H}), 6.26$ (t, $J=7.5 \mathrm{~Hz}, 1 \mathrm{H}), 3.60$ (q, $J=6.7 \mathrm{~Hz}, 2 \mathrm{H}), 2.49$ (q, $J=7.1 \mathrm{~Hz}, 2 \mathrm{H}) ;{ }^{13} \mathbf{C}$ 
NMR $\left(125 \mathrm{MHz}, \mathrm{CDCl}_{3}\right) \delta 164.29,149.79,147.97,146.60,142.72,138.43,137.38,131.97$, $129.68,129.13,128.59,127.75,127.65,126.16,122.19,118.99,110.48,38.93,30.46$; HRMS (ESI-TOF) Calcd for $\mathrm{C}_{23} \mathrm{H}_{19} \mathrm{~N}_{3} \mathrm{O}^{+}[\mathrm{M}+\mathrm{H}]^{+} 354.1601$, found 354.1603.

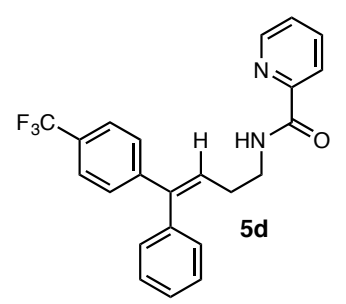

(E)- $N$-(4-phenyl-4-(4-(trifluoromethyl)phenyl)but-3-en-1-yl)picolinami de (5d): The title compound was prepared from $1 \mathbf{a}(25 \mathrm{mg}, 0.1 \mathrm{mmol})$ and $p$-trifluoromethylphenylboronic acid (34 $\mathrm{mg}, 0.18 \mathrm{mmol}$ ) according to the general procedure. Purification using silica gel chromatography with 3:1 hexanes:EtOAc as the eluent gave the product as a colorless oil $(27.7 \mathrm{mg}$, $70 \%$ yield). ${ }^{1} \mathbf{H}$ NMR $\left(600 \mathrm{MHz}, \mathrm{CDCl}_{3}\right) \delta 8.54-8.52(\mathrm{~m}, 1 \mathrm{H}), 8.18\left(\mathrm{dt}, J_{1}\right.$ $\left.=7.8 \mathrm{~Hz}, J_{2}=1.0 \mathrm{~Hz}, 1 \mathrm{H}\right), 8.07(\mathrm{t}, J=6.1 \mathrm{~Hz}, 1 \mathrm{H}), 7.84\left(\mathrm{td}, J_{I}=7.8 \mathrm{~Hz}, J_{2}=1.8 \mathrm{~Hz}, 1 \mathrm{H}\right), 7.50$ $(\mathrm{d}, J=8.1 \mathrm{~Hz}, 2 \mathrm{H}), 7.43-7.41(\mathrm{~m}, 1 \mathrm{H}), 7.37-7.31(\mathrm{~m}, 5 \mathrm{H}), 7.15-7.13(\mathrm{~m}, 2 \mathrm{H}), 6.21(\mathrm{t}, J=7.4$ $\mathrm{Hz}, 1 \mathrm{H}), 3.60(\mathrm{q}, J=6.7 \mathrm{~Hz}, 2 \mathrm{H}), 2.49$ (q, $J=7.1 \mathrm{~Hz}, 2 \mathrm{H}) ;{ }^{13} \mathbf{C}$ NMR $\left(150 \mathrm{MHz}, \mathrm{CDCl}_{3}\right) \delta$ $164.27,149.85,147.98,145.73,143.04,138.94,137.35,129.72,129.01\left(\mathrm{q}, J_{C-F}=32.2 \mathrm{~Hz}\right)$, 128.47, 127.94, 127.47, 126.12, 125.05 (q, $\left.J_{C-F}=3.6 \mathrm{~Hz}\right), 124.22\left(\mathrm{q}, J_{C-F}=271.8 \mathrm{~Hz}\right), 122.19$, 39.05, 30.31; HRMS (ESI-TOF) Calcd for $\mathrm{C}_{23} \mathrm{H}_{20} \mathrm{~F}_{3} \mathrm{~N}_{2} \mathrm{O}^{+}[\mathrm{M}+\mathrm{H}]^{+}$397.1522, found 397.1519.

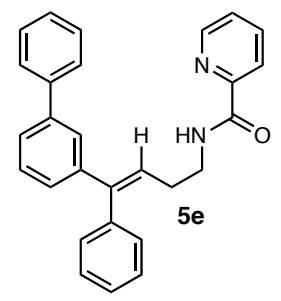

(E)-N-(4-([1,1'-biphenyl]-3-yl)-4-phenylbut-3-en-1-yl)picolinamide $\quad(5 \mathrm{e}):$ The title compound was prepared from $1 \mathrm{a}(25 \mathrm{mg}, 0.1 \mathrm{mmol})$ and [1,1'-biphenyl]-3-ylboronic acid (35.6 mg, $0.18 \mathrm{mmol})$ according to the general procedure. Purification using silica gel chromatography with $3: 1$ hexanes:EtOAc as the eluent gave the product as a colorless oil $(31.5 \mathrm{mg}, 78 \%$ yield). ${ }^{1} \mathbf{H}$ NMR $\left(600 \mathrm{MHz}, \mathrm{CDCl}_{3}\right) \delta 8.51(\mathrm{~d}, J=4.8 \mathrm{~Hz}, 1 \mathrm{H}), 8.18(\mathrm{~d}, J=7.8$ $\mathrm{Hz}, 1 \mathrm{H}), 8.09(\mathrm{bs}, 1 \mathrm{H}), 7.81\left(\mathrm{td}, J_{1}=7.7 \mathrm{~Hz}, J_{2}=1.8 \mathrm{~Hz}, 1 \mathrm{H}\right), 7.53-7.52(\mathrm{~m}, 2 \mathrm{H}), 7.46-7.28(\mathrm{~m}$, $10 \mathrm{H}), 7.24-7.18(\mathrm{~m}, 3 \mathrm{H}), 6.19(\mathrm{t}, J=7.5 \mathrm{~Hz}, 1 \mathrm{H}), 3.60(\mathrm{q}, J=6.7 \mathrm{~Hz}, 2 \mathrm{H}), 2.49$ (q, $J=7.2 \mathrm{~Hz}$, 2H); ${ }^{13}$ C NMR (150 MHz, $\left.\mathrm{CDCl}_{3}\right) \delta 164.20,149.89,147.94,144.11,142.84,141.12,141.06$, $139.61,137.26,129.77,128.65,128.48,128.27,127.20,127.15,126.33,126.10,126.07,126.02$, 125.98, 122.13, 39.24, 30.14; HRMS (ESI-TOF) Calcd for $\mathrm{C}_{28} \mathrm{H}_{25} \mathrm{~N}_{2} \mathrm{O}^{+}[\mathrm{M}+\mathrm{H}]^{+} 405.1961$, found 405.1962 .

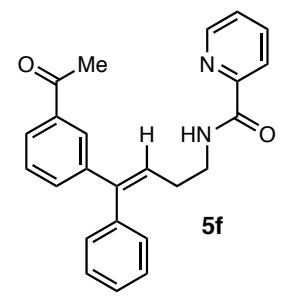

(E)-N-(4-(3-acetylphenyl)-4-phenylbut-3-en-1-yl)picolinamide (5f): The title compound was prepared from $1 \mathbf{a}(25 \mathrm{mg}, 0.1 \mathrm{mmol})$ and (3-acetylphenyl)boronic acid $(29.5 \mathrm{mg}, 0.18 \mathrm{mmol}$ ) according to the general procedure. Purification using silica gel chromatography with 3:1 hexanes:EtOAc as the eluent gave the product as a colorless oil $(24.2 \mathrm{mg}, 65 \%$ yield). ${ }^{1} \mathbf{H}$ NMR $\left(600 \mathrm{MHz}, \mathrm{CDCl}_{3}\right) \delta 8.53\left(\mathrm{ddd}, J_{I}=4.7 \mathrm{~Hz}, J_{2}=1.8 \mathrm{~Hz}, J_{3}=\right.$ $0.9 \mathrm{~Hz}, 1 \mathrm{H}), 8.19\left(\mathrm{dt}, J_{1}=7.9 \mathrm{~Hz}, J_{2}=1.1 \mathrm{~Hz}, 1 \mathrm{H}\right), 8.10(\mathrm{bs}, 1 \mathrm{H}), 7.87-7.80(\mathrm{~m}, 3 \mathrm{H}), 7.41$ (ddd, $\left.J_{1}=7.6 \mathrm{~Hz}, J_{2}=4.8 \mathrm{~Hz}, J_{3}=1.2 \mathrm{~Hz}, 1 \mathrm{H}\right), 7.38-7.30(\mathrm{~m}, 5 \mathrm{H}), 7.16-7.15(\mathrm{~m}, 2 \mathrm{H}), 6.19(\mathrm{t}, J=7.5$ 
$\mathrm{Hz}, 1 \mathrm{H}), 3.60(\mathrm{q}, J=6.9 \mathrm{~Hz}, 2 \mathrm{H}), 2.56(\mathrm{~s}, 3 \mathrm{H}), 2.49(\mathrm{q}, J=7.1 \mathrm{~Hz}, 2 \mathrm{H}) ;{ }^{13} \mathbf{C} \mathbf{N M R}(150 \mathrm{MHz}$, $\left.\mathrm{CDCl}_{3}\right) \delta 198.23,164.24,149.85,147.96,143.32,142.91,139.12,137.31,137.09,132.05$, $129.68,128.41,128.33,127.38,127.05,126.94,126.08,122.14,39.13,30.25,26.68$; HRMS (ESI-TOF) Calcd for $\mathrm{C}_{23} \mathrm{H}_{23} \mathrm{~N}_{2} \mathrm{O}^{+}[\mathrm{M}+\mathrm{H}]^{+} 371.1754$, found 371.1755 .

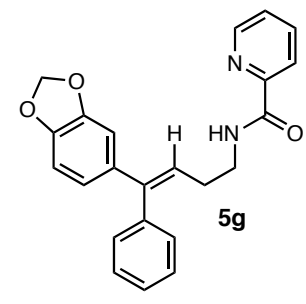

(E)-N-(4-(benzo[1,3]dioxol-5-yl)-4-phenylbut-3-en-1-yl)picolinamide (5g): The title compound was prepared from $1 \mathrm{a}(25 \mathrm{mg}, 0.1 \mathrm{mmol})$ and benzo[1,3]dioxol-5-ylboronic acid $(29.9 \mathrm{mg}, 0.18 \mathrm{mmol})$ according to the general procedure. Purification using silica gel chromatography with $3: 1$ hexanes:EtOAc as the eluent gave the product as a pale yellow oil $(31.4 \mathrm{mg}$, 84\% yield). ${ }^{1} \mathbf{H}$ NMR (600 MHz, $\left.\mathrm{CDCl}_{3}\right) \delta 8.52\left(\mathrm{ddd}, J_{1}=4.8 \mathrm{~Hz}, J_{2}=1.8\right.$ $\left.\mathrm{Hz}, J_{3}=0.9 \mathrm{~Hz}, 1 \mathrm{H}\right), 8.18\left(\mathrm{dt}, J_{1}=7.9 \mathrm{~Hz}, J_{2}=1.1 \mathrm{~Hz}, 1 \mathrm{H}\right), 8.06(\mathrm{t}, J=6.2 \mathrm{~Hz}, 1 \mathrm{H}), 7.83\left(\mathrm{td}, J_{1}\right.$ $\left.=7.7 \mathrm{~Hz}, J_{2}=1.7 \mathrm{~Hz}, 1 \mathrm{H}\right), 7.40\left(\mathrm{ddd}, J_{1}=7.6 \mathrm{~Hz}, J_{2}=4.8 \mathrm{~Hz}, J_{3}=1.3 \mathrm{~Hz}, 1 \mathrm{H}\right), 7.34-7.27(\mathrm{~m}$, $3 \mathrm{H}), 7.16-7.14(\mathrm{~m}, 2 \mathrm{H}), 6.75(\mathrm{~d}, J=1.7 \mathrm{~Hz}, 1 \mathrm{H}), 6.70-6.65(\mathrm{~m}, 2 \mathrm{H}), 6.02(\mathrm{t}, J=7.5 \mathrm{~Hz}, 1 \mathrm{H})$, $5.92(\mathrm{~s}, 2 \mathrm{H}), 3.55\left(\mathrm{td}, J_{l}=7.0 \mathrm{~Hz}, J_{2}=6.0 \mathrm{~Hz}, 2 \mathrm{H}\right), 2.42(\mathrm{q}, J=7.1 \mathrm{~Hz}, 2 \mathrm{H}) ;{ }^{13} \mathbf{C}$ NMR $(150$

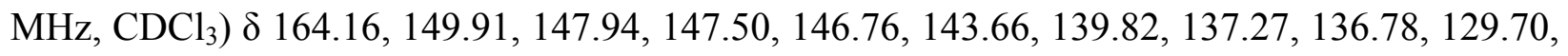
$128.24,127.10,126.02,124.47,122.13,121.11,107.81,107.60,100.96,39.26,30.06$; HRMS (ESI-TOF) Calcd for $\mathrm{C}_{23} \mathrm{H}_{20} \mathrm{~N}_{2} \mathrm{O}_{3}{ }^{+}[\mathrm{M}+\mathrm{H}]^{+} 373.1547$, found 373.549.

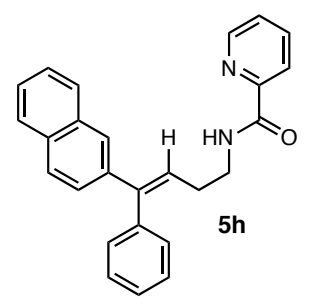

(E)- $N$-(4-(naphthalen-2-yl)-4-phenylbut-3-en-1-yl)picolinamide (5h): The title compound was prepared from $1 \mathrm{a}(25 \mathrm{mg}, 0.1 \mathrm{mmol})$ and naphthalen-2-ylboronic acid (31 $\mathrm{mg}, 0.18 \mathrm{mmol}$ ) according to the general procedure. Purification using silica gel chromatography with 3:1 hexanes:EtOAc as the eluent gave the product as a colorless solid $(20.4 \mathrm{mg}$, 54\% yield). ${ }^{1} \mathbf{H}$ NMR $\left(600 \mathrm{MHz}, \mathrm{CDCl}_{3}\right) \delta 8.53$ (ddd, $J_{l}=4.8 \mathrm{~Hz}, J_{2}=1.8$ $\left.\mathrm{Hz}, J_{3}=0.9 \mathrm{~Hz}, 1 \mathrm{H}\right), 8.19\left(\mathrm{dt}, J_{1}=7.8 \mathrm{~Hz}, J_{2}=1.1 \mathrm{~Hz}, 1 \mathrm{H}\right), 8.10(\mathrm{bs}, 1 \mathrm{H}), 7.83\left(\mathrm{td}, J_{1}=7.7 \mathrm{~Hz}\right.$, $\left.J_{2}=1.7 \mathrm{~Hz}, 1 \mathrm{H}\right), 7.79-7.77(\mathrm{~m}, 1 \mathrm{H}), 7.74-7.70(\mathrm{~m}, 2 \mathrm{H}), 7.55(\mathrm{~d}, J=1.8 \mathrm{~Hz}, 1 \mathrm{H}), 7.47\left(\mathrm{dd}, J_{1}=\right.$ $\left.8.6 \mathrm{~Hz}, J_{2}=1.9 \mathrm{~Hz}, 1 \mathrm{H}\right), 7.42-7.33(\mathrm{~m}, 6 \mathrm{H}), 7.23-7.21(\mathrm{~m}, 2 \mathrm{H}), 6.28(\mathrm{t}, J=7.5 \mathrm{~Hz}, 1 \mathrm{H}), 3.62$ $\left(\mathrm{td}, J_{1}=7.0 \mathrm{~Hz}, J_{2}=5.9 \mathrm{~Hz}, 2 \mathrm{H}\right), 2.52(\mathrm{q}, J=7.1 \mathrm{~Hz}, 2 \mathrm{H}) ;{ }^{13} \mathbf{C} \mathbf{N M R}\left(150 \mathrm{MHz}, \mathrm{CDCl}_{3}\right) \delta$ 164.23 , 149.93, 147.96, 144.11, 139.70, 139.59, 137.29, 133.25, 132.58, 129.90, 128.32, 128.15, $127.61,127.45,127.20,126.44,126.27,126.05,126.03,125.76,125.25,122.16,39.28,30.24$; HRMS (ESI-TOF) Calcd for $\mathrm{C}_{26} \mathrm{H}_{23} \mathrm{~N}_{2} \mathrm{O}^{+}[\mathrm{M}+\mathrm{H}]^{+} 379.1805$, found 379.1805.

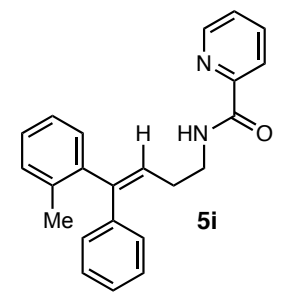

(E)- $N$-(4-phenyl-4-(o-tolyl)but-3-en-1-yl)picolinamide (5i): The title compound was prepared from $1 \mathrm{a}(25 \mathrm{mg}, 0.1 \mathrm{mmol})$ and $o$-tolylboronic acid (24.5 $\mathrm{mg}, 0.18 \mathrm{mmol}$ ) according to the general procedure. Purification using silica gel chromatography with 3:1 hexanes:EtOAc as the eluent gave the product as a colorless oil (7.5 mg, 22\% yield). ${ }^{1} \mathbf{H}$ NMR $\left(600 \mathrm{MHz}, \mathrm{CDCl}_{3}\right) \delta$ 
$8.53\left(\mathrm{dt}, J_{1}=4.9 \mathrm{~Hz}, J_{2}=1.3 \mathrm{~Hz}, 1 \mathrm{H}\right), 8.19\left(\mathrm{dt}, J_{1}=7.9 \mathrm{~Hz}, J_{2}=1.1 \mathrm{~Hz}, 1 \mathrm{H}\right), 8.14(\mathrm{bs}, 1 \mathrm{H}), 7.84$ $\left(\mathrm{td}, J_{1}=7.7 \mathrm{~Hz}, J_{2}=1.7 \mathrm{~Hz}, 1 \mathrm{H}\right), 7.41\left(\mathrm{ddd}, J_{1}=7.6 \mathrm{~Hz}, J_{2}=4.8 \mathrm{~Hz}, J_{3}=1.3 \mathrm{~Hz}, 1 \mathrm{H}\right)$, $7.28-7.09(\mathrm{~m}, 9 \mathrm{H}), 5.72(\mathrm{t}, J=7.3 \mathrm{~Hz}, 1 \mathrm{H}), 3.62$ (q, $J=6.7 \mathrm{~Hz}, 2 \mathrm{H}), 2.67(\mathrm{q}, J=7.1 \mathrm{~Hz}, 2 \mathrm{H})$, $2.05(\mathrm{~s}, 3 \mathrm{H}) ;{ }^{13} \mathrm{C}$ NMR $\left(150 \mathrm{MHz}, \mathrm{CDCl}_{3}\right) \delta 164.21,149.92,147.96,144.30,143.55,139.75$, 137.30, 135.99, 130.20, 130.07, 129.24, 127.99, 127.92, 127.19, 126.86, 126.06, 125.55, 122.14, 39.35, 29.50, 20.41; HRMS (ESI-TOF) Calcd for $\mathrm{C}_{23} \mathrm{H}_{23} \mathrm{~N}_{2} \mathrm{O}^{+}[\mathrm{M}+\mathrm{H}]^{+}$343.1805, found 343.1802 .

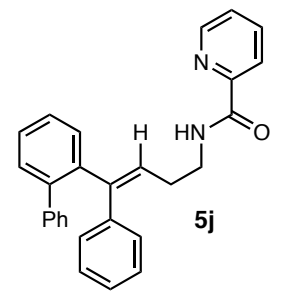

(E)-N-(4-([1,1'-biphenyl]-2-yl)-4-phenylbut-3-en-1-yl)picolinamide $\quad(5 \mathrm{j})$ : The title compound was prepared from $1 \mathrm{a}(25 \mathrm{mg}, 0.1 \mathrm{mmol})$ and [1,1'-biphenyl]-2-ylboronic acid (35.6 $\mathrm{mg}, 0.18 \mathrm{mmol})$ according to the general procedure. Purification using silica gel chromatography with $3: 1$ hexanes:EtOAc as the eluent gave the product as a colorless oil $(7.5 \mathrm{mg}, 18 \%$ yield). ${ }^{1} \mathbf{H}$ NMR $\left(600 \mathrm{MHz}, \mathrm{CDCl}_{3}\right) \delta 8.55\left(\mathrm{dd}, J_{l}=4.7 \mathrm{~Hz}, J_{2}=1.4 \mathrm{~Hz}, 1 \mathrm{H}\right)$, $8.16\left(\mathrm{dd}, J_{1}=7.9 \mathrm{~Hz}, J_{2}=1.1 \mathrm{~Hz}, 1 \mathrm{H}\right), 7.95(\mathrm{bs}, 1 \mathrm{H}), 7.88-7.80(\mathrm{~m}, 1 \mathrm{H}), 7.43-7.05(\mathrm{~m}, 13 \mathrm{H})$, 6.93-6.72 (m, 2H), 5.67 (t, $J=7.5 \mathrm{~Hz}, 1 \mathrm{H}), 3.33$ (q, $J=6.7 \mathrm{~Hz}, 2 \mathrm{H}), 2.45$ (q, $J=7.1 \mathrm{~Hz}, 2 \mathrm{H})$; ${ }^{13}$ C NMR $\left(150 \mathrm{MHz}, \mathrm{CDCl}_{3}\right) \delta 164.13,149.97,147.92,143.43,142.75,142.19,141.40,139.95$, $137.27,130.53,130.18,129.53,129.38,129.24,127.66,127.43,127.16,127.03,126.36,126.02$, 122.13, 39.08, 29.60; HRMS (ESI-TOF) Calcd for $\mathrm{C}_{28} \mathrm{H}_{25} \mathrm{~N}_{2} \mathrm{O}^{+}[\mathrm{M}+\mathrm{H}]^{+} 405.1961$, found 405.1957 .

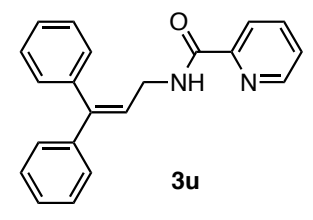

$\mathrm{N}$-(3,3-diphenylallyl)picolinamide (3u): The title compound was prepared from $1 \mathbf{u}(23.6 \mathrm{mg}, 0.1 \mathrm{mmol})$, and phenylboronic acid (22 $\mathrm{mg}, 0.18 \mathrm{mmol})$ according to the general procedure. Purification using silica gel chromatography with 3:1 hexanes:EtOAc as the eluent gave the product as a colorless oil. ${ }^{1} \mathbf{H}$ NMR $\left(600 \mathrm{MHz}, \mathrm{CDCl}_{3}\right) \delta 8.55\left(\mathrm{ddd}, J_{l}=4.7 \mathrm{~Hz}, J_{2}=1.7\right.$ $\left.\mathrm{Hz}, J_{3}=0.9 \mathrm{~Hz}, 1 \mathrm{H}\right), 8.20\left(\mathrm{dt}, J_{1}=7.9 \mathrm{~Hz}, J_{2}=1.1 \mathrm{~Hz}, 1 \mathrm{H}\right), 8.10(\mathrm{bs}, 1 \mathrm{H}), 7.84\left(\mathrm{td}, J_{1}=7.7 \mathrm{~Hz}\right.$, $\left.J_{2}=1.8 \mathrm{~Hz}, 1 \mathrm{H}\right), 7.43-7.39(\mathrm{~m}, 3 \mathrm{H}), 7.36-7.33(\mathrm{~m}, 1 \mathrm{H}), 7.29-7.23(\mathrm{~m}, 7 \mathrm{H}), 6.19(\mathrm{t}, J=7.0 \mathrm{~Hz}$, $1 \mathrm{H}), 4.17\left(\mathrm{dd}, J_{1}=7.1 \mathrm{~Hz}, J_{2}=5.9 \mathrm{~Hz}, 2 \mathrm{H}\right) ;{ }^{13} \mathrm{C}$ NMR $\left(150 \mathrm{MHz}, \mathrm{CDCl}_{3}\right) \delta 164.06,149.90$, 148.02 , 144.71, 141.63, 138.95, 137.32, 129.73, 128.38, 128.14, 127.54, 127.53, 127.44, 126.13, 124.41, 122.22, 38.86; HRMS (ESI-TOF) Calcd for $\mathrm{C}_{21} \mathrm{H}_{19} \mathrm{~N}_{2} \mathrm{O}^{+}[\mathrm{M}+\mathrm{H}]^{+}$315.1492, found 315.1487 .

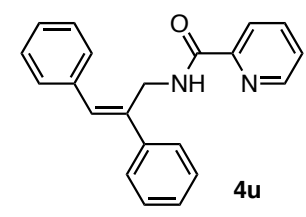

(E)-N-(3,4-diphenylbut-3-en-1-yl)picolinamide (4u): The title compound was prepared from $1 \mathbf{u}(23.6 \mathrm{mg}, 0.1 \mathrm{mmol})$, and phenylboronic acid (22 $\mathrm{mg}$, $0.18 \mathrm{mmol}$ ) according to the general procedure. Purification using silica gel chromatography with 3:1 hexanes:EtOAc as the eluent gave the product as a colorless oil. ${ }^{1} \mathbf{H}$ NMR $\left(600 \mathrm{MHz}, \mathrm{CDCl}_{3}\right) \delta 8.45-8.43(\mathrm{~m}, 1 \mathrm{H}), 8.17\left(\mathrm{dt}, J_{1}=\right.$ 
$\left.7.8 \mathrm{~Hz}, J_{2}=1.1 \mathrm{~Hz}, 1 \mathrm{H}\right), 8.00(\mathrm{bs}, 1 \mathrm{H}), 7.80\left(\mathrm{td}, J_{1}=7.8 \mathrm{~Hz}, J_{2}=1.7 \mathrm{~Hz}, 1 \mathrm{H}\right), 7.61-7.59(\mathrm{~m}$, 2H), 7.40-7.28 (m, 9H), $7.09(\mathrm{~s}, 1 \mathrm{H}), 4.76(\mathrm{~d}, J=5.4 \mathrm{~Hz}, 2 \mathrm{H}) ;{ }^{13} \mathbf{C} \mathbf{N M R}\left(150 \mathrm{MHz}, \mathrm{CDCl}_{3}\right) \delta$ $164.15,149.66,148.02,140.05,137.25,137.21,136.82,131.77,128.85,128.63,128.53,127.81$, 127.38, 126.44, 126.05, 122.13, 38.74; HRMS (ESI-TOF) Calcd for $\mathrm{C}_{21} \mathrm{H}_{19} \mathrm{~N}_{2} \mathrm{O}^{+}[\mathrm{M}+\mathrm{H}]^{+}$ 315.1492 , found 315.1494 .

Table S1. Unsuccessful Examples.

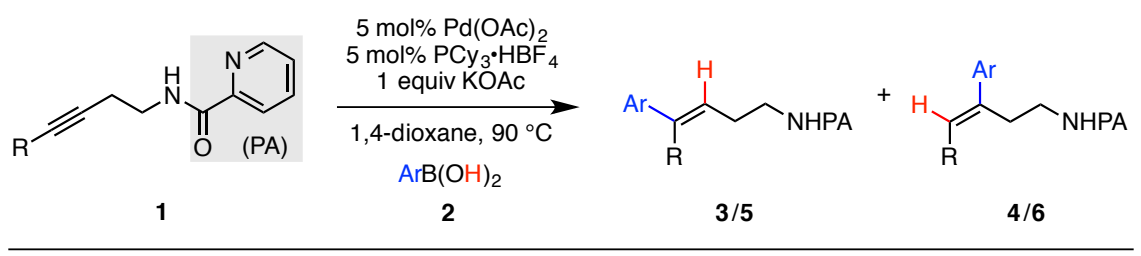

Alkyne Substrates (tested using $\left.\mathrm{PhB}(\mathrm{OH})_{2}(2 a)\right)$

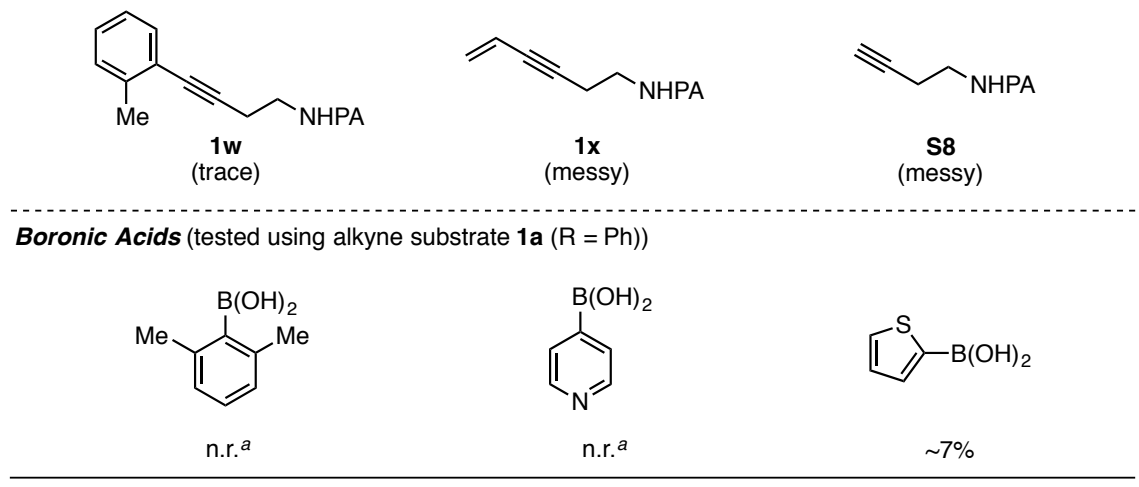

${ }^{a}$ n.r. = no reaction. 
Representative ${ }^{1} H$ NMR spectra of crude reaction mixtures from which yield and regioselectivity were determined: Following the general hydroarylation procedure, a predetermined quantity of $\mathrm{CH}_{2} \mathrm{Br}_{2}$ was added to the crude reaction mixture, and an aliquot was removed for analysis by ${ }^{1} \mathrm{H}$ NMR. The three representative examples below illustrate the peaks that were integrated for determining yield and selectivity. Peaks corresponding to one known byproduct (the semi-reduced disubstituted alkene) are also highlighted.
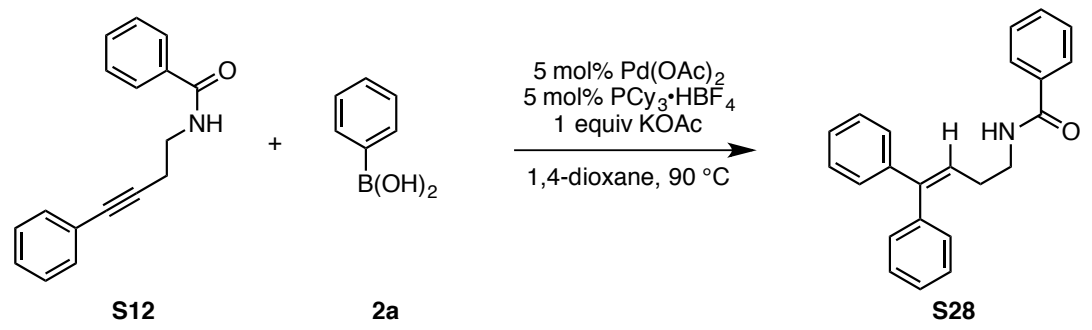

selectivity $5.8: 1$

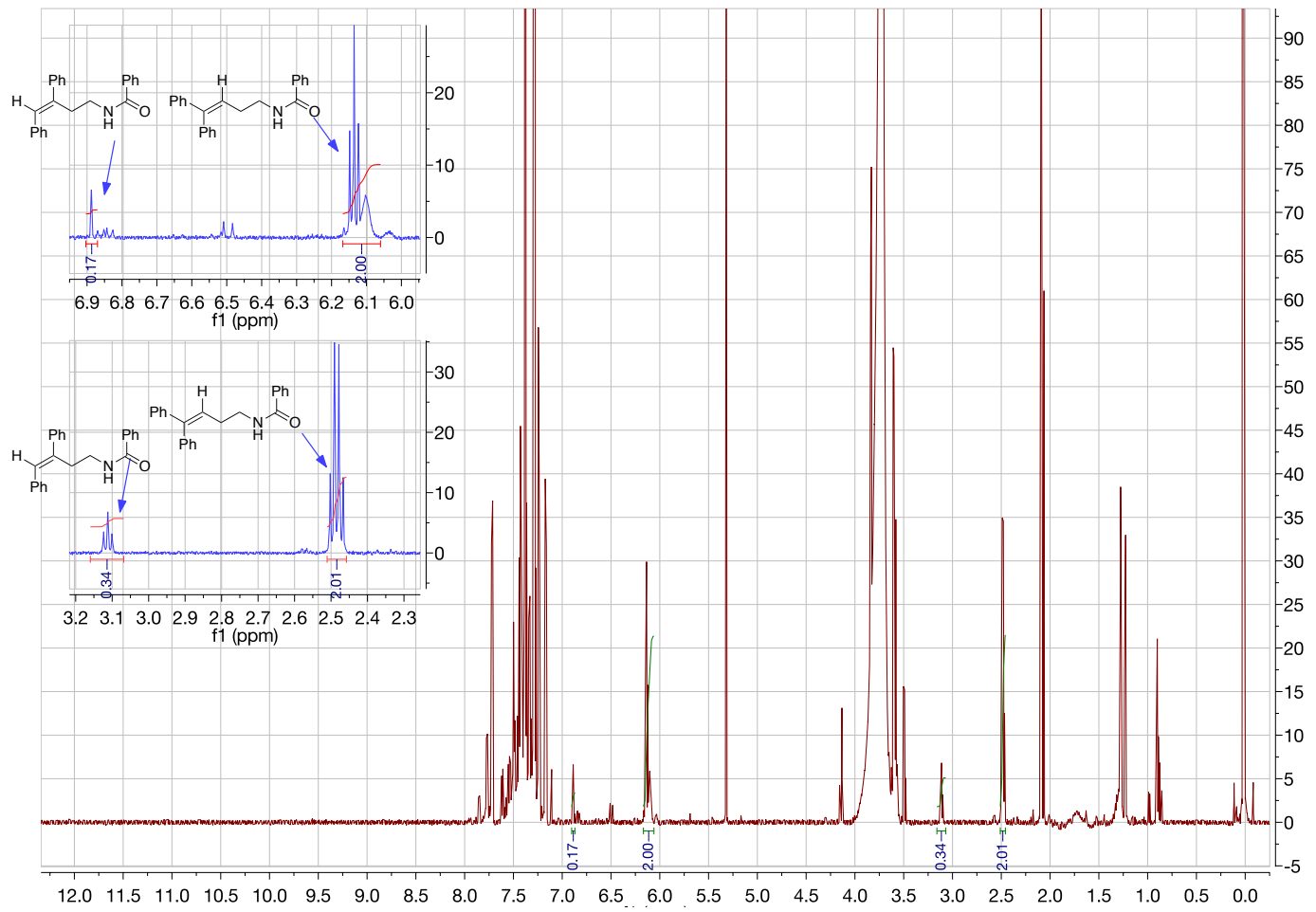




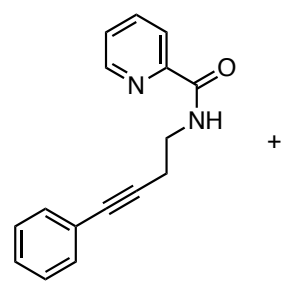

$1 a$<smiles>Oc1ccccc1</smiles>

$2 a$

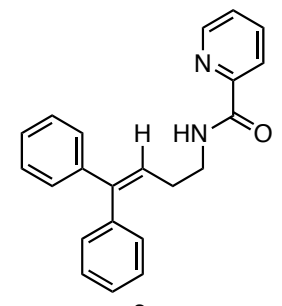

$3 a$

selectivity $>50: 1$

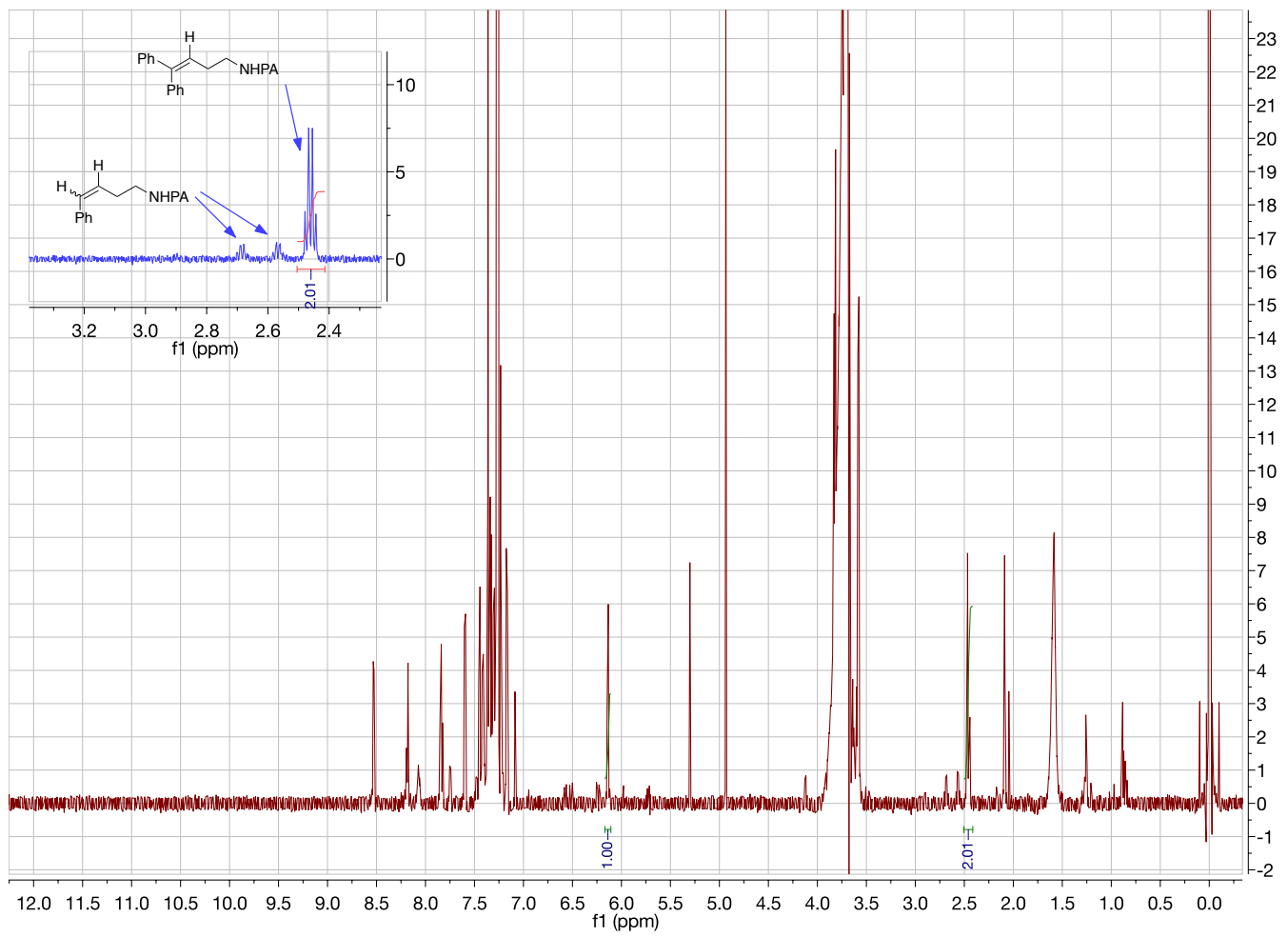




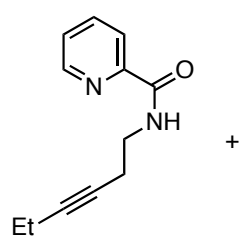

$1 q$

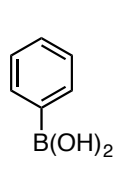

2a

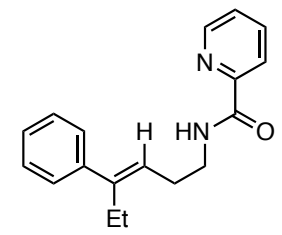

$3 q$

selectivity $>50: 1$

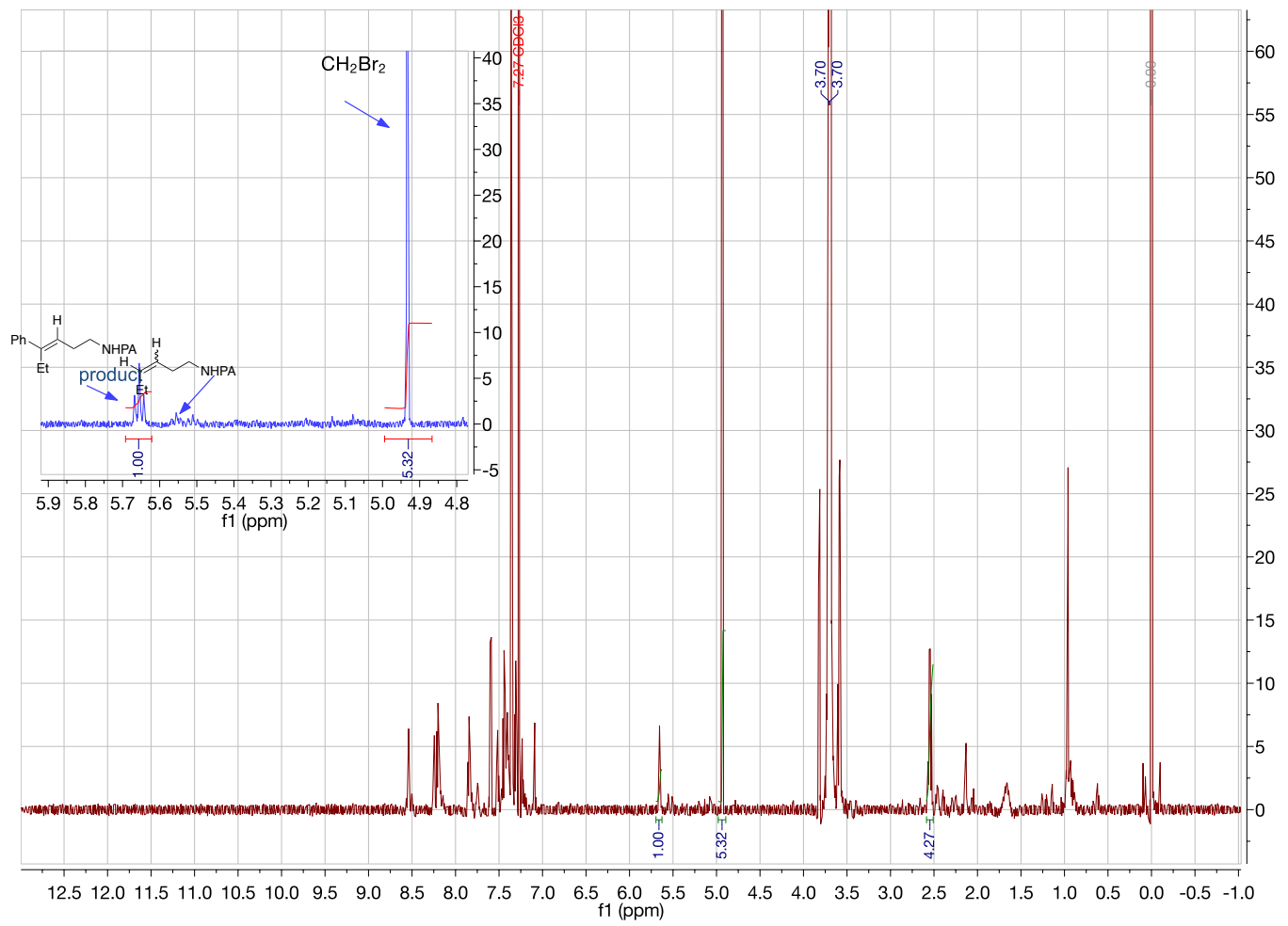

Characterization of Products in Directing Group Optimization<smiles>O=C(NCCC=C(c1ccccc1)c1ccccc1)c1ccccc1</smiles>

$\boldsymbol{N}$-(4,4-diphenylbut-3-en-1-yl)benzamide (S28): The title compound was prepared from $N$-(4-phenylbut-3-yn-1-yl)benzamide (S8) (25.1 mg, 0.1 $\mathrm{mmol})$, and phenylboronic acid (22 $\mathrm{mg}, 0.18 \mathrm{mmol}$ ) according to the general procedure. Purification using silica gel chromatography with 15:1 hexanes:EtOAc as the eluent gave the product as a white powder. ${ }^{1} \mathbf{H}$ NMR $\left(600 \mathrm{MHz}, \mathrm{CDCl}_{3}\right) \delta$ 7.71-7.69 (m, 2H), 7.50-7.47 (m, 1H), 7.43-7.30 (m, 5H), 7.28-7.21 (m, 5H), 7.16-7.14 (m, 2H), $6.12(\mathrm{t}, J=7.5 \mathrm{~Hz}, 1 \mathrm{H}), 6.04(\mathrm{bs}, 1 \mathrm{H}), 3.57\left(\mathrm{td}, J_{l}=6.9 \mathrm{~Hz}, J_{2}=5.7 \mathrm{~Hz}, 2 \mathrm{H}\right), 2.47(\mathrm{q}, J=$ 
$7.0 \mathrm{~Hz}, 2 \mathrm{H}) ;{ }^{13} \mathbf{C}$ NMR $\left(150 \mathrm{MHz}, \mathrm{CDCl}_{3}\right) \delta 167.48,144.31,142.15,139.69,134.67,131.36$, $129.78,128.53,128.37,128.16,127.26,127.23,126.79,125.61,109.97,39.85,30.00$; HRMS (ESI-TOF) Calcd for $\mathrm{C}_{23} \mathrm{H}_{21} \mathrm{NO}^{+}[\mathrm{M}+\mathrm{H}]^{+} 328.1696$, found 328.1701.

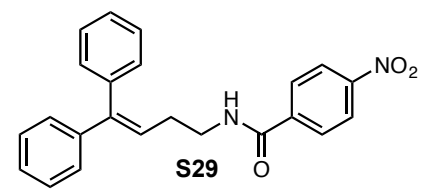

$N$-(4,4-diphenylbut-3-en-1-yl)-4-nitrobenzamide (S29): The title compound was prepared from $N$-(4-(4-nitrophenyl)but-3-yn -1-yl)benzamide (S3) (29.4 mg, $0.1 \mathrm{mmol}$ ), and phenylboronic acid (22 $\mathrm{mg}, 0.18 \mathrm{mmol}$ ) according to the general procedure. Purification using silica gel chromatography with 5:1 hexanes:EtOAc as the eluent gave the product as a white powder. ${ }^{1} \mathbf{H}$ NMR $\left(600 \mathrm{MHz}, \mathrm{CDCl}_{3}\right) \delta 8.27-8.25(\mathrm{~m}, 2 \mathrm{H}), 7.86-7.83(\mathrm{~m}, 2 \mathrm{H}), 7.38-7.31$ (m, 3H), 7.28-7.20 (m, 5H), 7.15-7.13 (m, 2H), 6.12-6.09 (m, 2H), $3.58\left(\mathrm{td}, J_{1}=6.9 \mathrm{~Hz}, J_{2}=\right.$ $5.7 \mathrm{~Hz}, 2 \mathrm{H}), 2.49$ (q, $J=7.0 \mathrm{~Hz}, 2 \mathrm{H}) ;{ }^{13} \mathbf{C}$ NMR $\left(150 \mathrm{MHz}, \mathrm{CDCl}_{3}\right) \delta 165.41,149.52,144.65$, $141.96,140.19,139.56,129.73,128.43,128.22,128.01,127.39,127.36,127.23,125.07,123.80$, 40.16, 29.80; HRMS (ESI-TOF) Calcd for $\mathrm{C}_{23} \mathrm{H}_{20} \mathrm{~N}_{2} \mathrm{O}_{3}{ }^{+}[\mathrm{M}+\mathrm{H}]^{+} 373.1547$, found 373.1549.

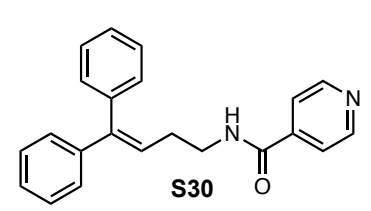

$N$-(4,4-diphenylbut-3-en-1-yl)isonicotinamide (S30): The title compound was prepared from $N$-(4-phenylbut-3-yn-1-yl) isonicotinamide (S5) $(25 \mathrm{mg}, 0.1 \mathrm{mmol})$, and phenylboronic acid $(22 \mathrm{mg}, 0.18 \mathrm{mmol})$ according to the general procedure. Purification using silica gel chromatography with 3:1 hexanes:EtOAc as the eluent gave the product as a colorless oil. ${ }^{1} \mathbf{H}$ NMR $\left(600 \mathrm{MHz}, \mathrm{CDCl}_{3}\right) \delta 8.72-8.71(\mathrm{~m}, 2 \mathrm{H}), 7.57-7.53(\mathrm{~m}, 2 \mathrm{H}), 7.38-7.31(\mathrm{~m}, 3 \mathrm{H}), 7.29-7.20$ (m, 5H), 7.15-7.13 (m, 2H), 6.11-6.09 (m, 2H), $3.57\left(\mathrm{td}, J_{1}=6.8 \mathrm{~Hz}, J_{2}=5.7 \mathrm{~Hz}, 2 \mathrm{H}\right), 2.48(\mathrm{q}, J$ $=7.1 \mathrm{~Hz}, 2 \mathrm{H}) ;{ }^{13} \mathbf{C}$ NMR $\left(150 \mathrm{MHz}, \mathrm{CDCl}_{3}\right) \delta 165.48,150.57,144.64,141.98,141.64,139.57$, $129.73,128.43,128.21,127.37,127.34,127.23,125.09,120.74,39.99,29.79$; HRMS (ESI-TOF) Calcd for $\mathrm{C}_{22} \mathrm{H}_{20} \mathrm{~N}_{2} \mathrm{O}^{+}[\mathrm{M}+\mathrm{H}]^{+} 329.1648$, found 329.1654.

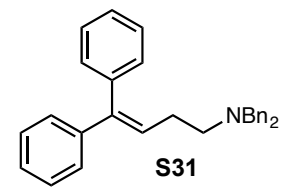

$\boldsymbol{N}, \boldsymbol{N}$-dibenzyl-4,4-diphenylbut-3-en-1-amine (S31): The title compound was prepared from $N, N$-dibenzyl-4-phenylbut-3-yn-1-amine (S6) (32.5 mg, 0.1 $\mathrm{mmol})$, and phenylboronic acid $(22 \mathrm{mg}, 0.18 \mathrm{mmol})$ according to the general procedure. Purification using silica gel chromatography with 20:1 hexanes:EtOAc as the eluent gave the product as a white powder. ${ }^{1} \mathbf{H} \mathbf{~ N M R}\left(600 \mathrm{MHz}, \mathrm{CDCl}_{3}\right) \delta$ 7.34-7.16 (m, 18H), 7.10-7.08 (m, 2H), 6.04 (t, $J=7.3 \mathrm{~Hz}, 1 \mathrm{H}), 3.51$ (s, 4H), 2.54 (t, $J=7.1 \mathrm{~Hz}$, $2 \mathrm{H}), 2.32$ (q, $J=7.2 \mathrm{~Hz}, 2 \mathrm{H}) ;{ }^{13} \mathbf{C}$ NMR $\left(150 \mathrm{MHz}, \mathrm{CDCl}_{3}\right) \delta 142.70,142.10,140.09,139.78$, 129.83, 128.78, 128.14, 128.12, 128.02, 127.98, 127.18, 126.86, 126.76, 58.09, 53.06, 27.40; HRMS (ESI-TOF) Calcd for $\mathrm{C}_{30} \mathrm{H}_{29} \mathrm{~N}^{+}[\mathrm{M}+\mathrm{H}]^{+} 404.2373$, found 404.2379. 


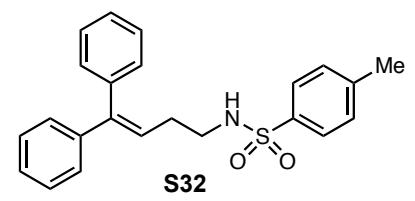

$N$-(4,4-diphenylbut-3-en-1-yl)-4-methylbenzenesulfonamide (S32): The title compound was prepared from 4-methyl- $N$-(4-phenylbut-3-yn-1-yl)benzenesulfonamide (S7) $\quad(29.9$ $\mathrm{mg}, 0.1 \mathrm{mmol})$, and phenylboronic acid (22 $\mathrm{mg}, 0.18 \mathrm{mmol}$ ) according to the general procedure. Purification using silica gel chromatography with 3:1 hexanes:EtOAc as the eluent gave the product as a colorless oil. ${ }^{1} \mathbf{H}$ NMR $\left(600 \mathrm{MHz}, \mathrm{CDCl}_{3}\right) \delta$ 7.69-7.68 (m, 2H), 7.43-7.30 (m, 4H), 7.25-7.22 (m, 4H), 7.15-7.14 (m, 2H), 7.10-7.09 (m, 2H), $5.90(\mathrm{t}, J=$ $7.4 \mathrm{~Hz}, 1 \mathrm{H}), 4.36(\mathrm{t}, J=6.0 \mathrm{~Hz}, 1 \mathrm{H}), 3.04(\mathrm{q}, J=6.8 \mathrm{~Hz}, 2 \mathrm{H}), 2.41$ (s, 3H), 2.27 (q, $J=7.0 \mathrm{~Hz}$, $2 \mathrm{H}) ;{ }^{13} \mathbf{C}$ NMR $\left(150 \mathrm{MHz}, \mathrm{CDCl}_{3}\right) \delta 144.80,143.34,141.88,139.38,136.85,129.67,129.64$, $128.35,128.12$, 127.32, 127.25, 127.19, 127.06, 124.42, 43.03, 29.82, 21.52; HRMS (ESI-TOF) Calcd for $\mathrm{C}_{23} \mathrm{H}_{23} \mathrm{~N}_{2} \mathrm{O}_{2} \mathrm{~S}^{+}[\mathrm{M}+\mathrm{H}]^{+}$378.1522, found 378.1527.

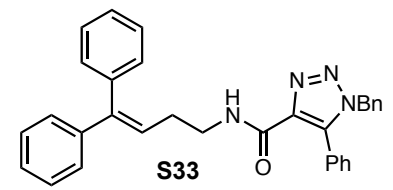

1-benzyl- $\mathrm{N}$-(4,4-diphenylbut-3-en-1-yl)-5-phenyl-1 $\mathrm{H}$-1,2,3-triazole-4 -carboxamide (S33): The title compound was prepared from 1-benzyl-5-phenyl- $N$-(4-phenylbut-3-yn-1-yl)-1H-1,2,3-triazole-4-carbo xamide (S14) (40.6 mg, $0.1 \mathrm{mmol})$, and phenylboronic acid $(22 \mathrm{mg}$, $0.18 \mathrm{mmol}$ ) according to the general procedure. Purification using silica gel chromatography with 3:1 hexanes:EtOAc as the eluent gave the product as a colorless oil. ${ }^{1} \mathbf{H}$ NMR (600 MHz, $\left.\mathrm{CDCl}_{3}\right) \delta 7.47-7.40(\mathrm{~m}, 3 \mathrm{H}), 7.35-7.15(\mathrm{~m}, 16 \mathrm{H}), 7.01-6.99(\mathrm{~m}, 2 \mathrm{H}), 6.08(\mathrm{t}, J=7.5 \mathrm{~Hz}, 1 \mathrm{H})$, $5.42(\mathrm{~s}, 2 \mathrm{H}), 3.48(\mathrm{q}, J=6.7 \mathrm{~Hz}, 2 \mathrm{H}), 2.40(\mathrm{q}, J=7.1 \mathrm{~Hz}, 2 \mathrm{H}) ;{ }^{13} \mathbf{C}$ NMR $\left(150 \mathrm{MHz}, \mathrm{CDCl}_{3}\right) \delta$ $160.17,144.11,142.20,139.73,139.20,138.97,134.78,129.98,129.88,129.79,128.80,128.45$, 128.36, 128.28, 128.08, 127.45, 127.24, 127.08, 125.95, 125.63, 52.00, 38.79, 30.15; HRMS (ESI-TOF) Calcd for $\mathrm{C}_{32} \mathrm{H}_{28} \mathrm{~N}_{4} \mathrm{O}^{+}[\mathrm{M}+\mathrm{H}]^{+} 485.2336$, found 485.2344.

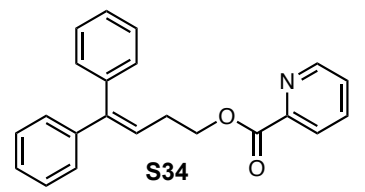

4,4-diphenylbut-3-en-1-yl picolinate (S34): The title compound was prepared from 4-phenylbut-3-yn-1-yl picolinate (S15) $(25.2 \mathrm{mg}, 0.1$ $\mathrm{mmol})$, and phenylboronic acid (22 $\mathrm{mg}, 0.18 \mathrm{mmol}$ ) according to the general procedure. Purification using silica gel chromatography with 3:1

hexanes:EtOAc as the eluent gave the product as a colorless oil. ${ }^{1} \mathbf{H}$ NMR $\left(600 \mathrm{MHz}, \mathrm{CDCl}_{3}\right) \delta$ $8.76\left(\mathrm{ddd}, J_{I}=4.8 \mathrm{~Hz}, J_{2}=1.8 \mathrm{~Hz}, J_{3}=0.9 \mathrm{~Hz}, 1 \mathrm{H}\right), 8.11\left(\mathrm{dt}, J_{l}=7.8 \mathrm{~Hz}, J_{2}=1.1 \mathrm{~Hz}, 1 \mathrm{H}\right), 7.83$ (td, $\left.J_{1}=7.7 \mathrm{~Hz}, J_{2}=1.8 \mathrm{~Hz}, 1 \mathrm{H}\right), 7.53-7.50(\mathrm{~m}, 1 \mathrm{H}), 7.47$ (ddd, $J_{1}=7.6 \mathrm{~Hz}, J_{2}=4.7 \mathrm{~Hz}, J_{3}=$ $1.2 \mathrm{~Hz}, 1 \mathrm{H}), 7.37-7.31(\mathrm{~m}, 3 \mathrm{H}), 7.27-7.17(\mathrm{~m}, 6 \mathrm{H}), 6.14(\mathrm{t}, J=7.5 \mathrm{~Hz}, 1 \mathrm{H}), 4.49$ (t, $J=7.1 \mathrm{~Hz}$, $2 \mathrm{H}), 2.66(\mathrm{q}, J=7.2 \mathrm{~Hz}, 2 \mathrm{H}) ;{ }^{13} \mathbf{C}$ NMR $\left(150 \mathrm{MHz}, \mathrm{CDCl}_{3}\right) \delta 165.12,149.87,148.05,144.56$, 142.20, 139.59, 136.98, 135.62, 129.74, 128.29, 128.10, 127.27, 127.19, 126.87, 125.15, 123.80, 65.26, 29.46; HRMS (ESI-TOF) Calcd for $\mathrm{C}_{22} \mathrm{H}_{19} \mathrm{NO}_{2}{ }^{+}[\mathrm{M}+\mathrm{H}]^{+}$330.1489, found 330.1488. 


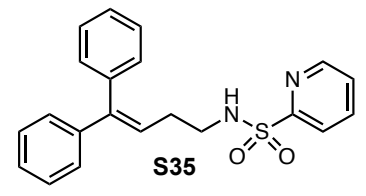

$N$-(4,4-diphenylbut-3-en-1-yl)pyridine-2-sulfonamide (S35): The title compound was prepared from $N$-(4-phenylbut-3-yn-1-yl) pyridine-2-sulfonamide (S10) $(28.6 \mathrm{mg}, 0.1 \mathrm{mmol})$, and phenylboronic acid $(22 \mathrm{mg}, 0.18 \mathrm{mmol}$ ) according to the general procedure. Purification

using silica gel chromatography with 3:1 hexanes:EtOAc as the eluent gave the product as a white powder. ${ }^{1} \mathbf{H} \mathbf{~ N M R}\left(600 \mathrm{MHz}, \mathrm{CDCl}_{3}\right) \delta 8.63\left(\mathrm{ddd}, J_{I}=4.7 \mathrm{~Hz}, J_{2}=1.7, J_{3}=0.9 \mathrm{~Hz}, 1 \mathrm{H}\right)$, $7.96\left(\mathrm{dt}, J_{1}=7.8 \mathrm{~Hz}, J_{2}=1.1 \mathrm{~Hz}, 1 \mathrm{H}\right), 7.86\left(\mathrm{td}, J_{l}=7.7 \mathrm{~Hz}, J_{2}=1.7 \mathrm{~Hz}, 1 \mathrm{H}\right), 7.43\left(\mathrm{ddd}, J_{l}=7.6\right.$ $\left.\mathrm{Hz}, J_{2}=4.7 \mathrm{~Hz}, J_{3}=1.1 \mathrm{~Hz}, 1 \mathrm{H}\right), 7.37-7.34(\mathrm{~m}, 2 \mathrm{H}), 7.32-7.29(\mathrm{~m}, 1 \mathrm{H}), 7.27-7.22(\mathrm{~m}, 3 \mathrm{H})$, 7.18-7.16 (m, 2H), 7.12-7.11 (m, 2H), 5.95 (t, $J=7.4 \mathrm{~Hz}, 1 \mathrm{H}), 4.95(\mathrm{t}, J=6.1 \mathrm{~Hz}, 1 \mathrm{H}), 3.17(\mathrm{td}$, $\left.J_{1}=6.8 \mathrm{~Hz}, J_{2}=6.1 \mathrm{~Hz}, 2 \mathrm{H}\right), 2.31(\mathrm{q}, J=7.0 \mathrm{~Hz}, 2 \mathrm{H}) ;{ }^{13} \mathbf{C} \mathbf{N M R}\left(150 \mathrm{MHz}, \mathrm{CDCl}_{3}\right) \delta 157.42$, $150.00,144.76,141.96,139.43,137.93,129.66,128.33,128.11,127.30,127.23,126.54,124.44$, 122.09, 43.63, 30.10; HRMS (ESI-TOF) Calcd for $\mathrm{C}_{21} \mathrm{H}_{21} \mathrm{~N}_{2} \mathrm{O}_{2} \mathrm{~S}^{+}[\mathrm{M}+\mathrm{H}]^{+} 365.1318$, found 365.1326 .

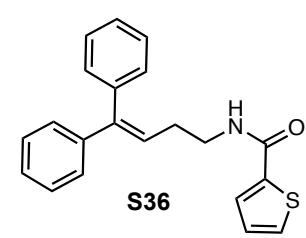

$N$-(4,4-diphenylbut-3-en-1-yl)thiophene-2-carboxamide (S36): The title compound was prepared from $N$-(4-phenylbut-3-yn-1-yl)thiophene2-carboxamide (S12) (25.5 mg, $0.1 \mathrm{mmol}$ ), and phenylboronic acid (22 $\mathrm{mg}$, $0.18 \mathrm{mmol}$ ) according to the general procedure. Purification using silica gel chromatography with 15:1 hexanes:EtOAc as the eluent gave the product as a white powder. ${ }^{1} \mathbf{H}$ NMR $\left(600 \mathrm{MHz}, \mathrm{CDCl}_{3}\right) \delta$ 7.45-7.42 (m, 2H), 7.38-7.35 (m, 2H), 7.33-7.30 (m, 1H), 7.28-7.21 (m, 5H), 7.17-7.15 (m, 2H), $7.05\left(\mathrm{dd}, J_{1}=5.0 \mathrm{~Hz}, J_{2}=3.7 \mathrm{~Hz}, 1 \mathrm{H}\right), 6.09(\mathrm{t}, J$ $=7.5 \mathrm{~Hz}, 1 \mathrm{H}), 5.92(\mathrm{bs}, 1 \mathrm{H}), 3.53\left(\mathrm{td}, J_{I}=6.9 \mathrm{~Hz}, J_{2}=5.7 \mathrm{~Hz}, 2 \mathrm{H}\right), 2.45(\mathrm{q}, J=7.1 \mathrm{~Hz}, 2 \mathrm{H}) ;{ }^{13} \mathbf{C}$ NMR $\left(150 \mathrm{MHz}, \mathrm{CDCl}_{3}\right) \delta 161.80,144.40,142.12,139.68,138.90,129.76,129.67,128.37$, 128.15, 127.90, 127.54, 127.25, 127.23, 127.22, 125.46, 39.75, 29.99; HRMS (ESI-TOF) Calcd for $\mathrm{C}_{21} \mathrm{H}_{19} \mathrm{NOS}^{+}[\mathrm{M}+\mathrm{H}]^{+} 334.1260$, found 334.1263. 
General Method for Removal of Picolinamide Directing Group

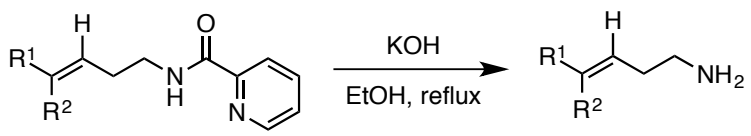

Scheme S9: Hydrolysis of the picolinamide directing group.

General Picolinamide Hydrolysis Procedure: Removal of the picolinamide directing group was carried out by adapting a literature procedure. ${ }^{13}$ To a flame-dried $250-\mathrm{mL}$ sealed vessel was added the hydroarylation product ( $1 \mathrm{mmol}), \mathrm{KOH}(60 \mathrm{mmol}, 60$ equiv), and $30 \mathrm{~mL}$ of EtOH. The resulting mixture was stirred at $125^{\circ} \mathrm{C}$ for $48 \mathrm{~h}$. After the reaction was complete, the reaction mixture was allowed to cool to room temperature, diluted by addition of EtOAc $(50 \mathrm{~mL})$ and washed with $\mathrm{H}_{2} \mathrm{O}(2 \times 20 \mathrm{~mL})$. The organic layer was dried over $\mathrm{Na}_{2} \mathrm{SO}_{4}$ and concentrated in vacuo to give pure amine product.

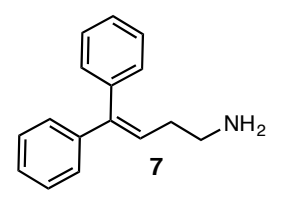

4,4-diphenylbut-3-en-1-amine (7): The title compound was prepared from $N$-(4,4-diphenylbut-3-en-1-yl) picolinamide (3a) (230 $\mathrm{mg}, 0.7 \mathrm{mmol}$ ) by adapting a literature procedure. Following a straightforward work-up, the product was obtained as a yellow oil (148 $\mathrm{mg}, 95 \%$ yield). ${ }^{1} \mathbf{H}$ NMR (600 $\left.\mathrm{MHz}, \mathrm{CDCl}_{3}\right) \delta 7.39-7.16(\mathrm{~m}, 10 \mathrm{H}), 6.08(\mathrm{t}, J=7.5 \mathrm{~Hz}, 1 \mathrm{H}), 2.81(\mathrm{t}, J=6.9 \mathrm{~Hz}, 2 \mathrm{H}), 2.28(\mathrm{q}, J$ $=7.1 \mathrm{~Hz}, 2 \mathrm{H}), 1.57(\mathrm{bs}, 2 \mathrm{H}) ;{ }^{13} \mathbf{C}$ NMR $\left(150 \mathrm{MHz}, \mathrm{CDCl}_{3}\right) \delta 143.55,142.46,139.98,129.86$, $128.22,128.08,127.17,127.00,126.99,126.73,42.29,34.06$.

Procedure for the Deuterium-Labeling Experiment

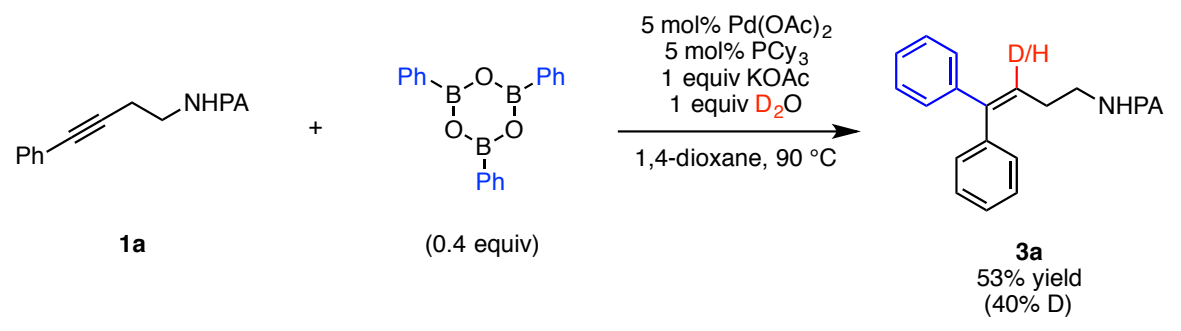

Deuterium-Labeling Experiment: To a 5-mL scintillation vial equipped with a Teflon-coated magnetic stir bar were added the homopropargyl picolinamide $1 \mathbf{a}$ (25 $\mathrm{mg}, 0.1 \mathrm{mmol})$, phenylboroxine (12.5 mg, $0.04 \mathrm{mmol}), \mathrm{Pd}(\mathrm{OAc})_{2}(1.1 \mathrm{mg}, 5 \mathrm{~mol} \%), \mathrm{PCy}_{3}(1.4 \mathrm{mg}, 5 \mathrm{~mol} \%)$, and KOAc $(9.8 \mathrm{mg}, 0.1 \mathrm{mmol})$. The vial was sealed with a screw-top septum cap and was then evacuated and backfilled with $\mathrm{N}_{2}$ three times. Under a positive pressure of $\mathrm{N}_{2}$, anhydrous dioxane $(0.4 \mathrm{~mL})$ was added, followed with $\mathrm{D}_{2} \mathrm{O}(2.2 \mu \mathrm{L}, 1$ equiv). All needle inlets/outlets were removed, and the reaction was allowed to stir at $90{ }^{\circ} \mathrm{C}$ for $4 \mathrm{~h}$. After this time, the reaction vial was allowed cooled to room temperature, and the reaction mixture was filtered through a short plug of silica gel (1:1 hexanes:EtOAc, $10 \mathrm{~mL}$, as eluent). The solvent was removed in vacuo to 
leave a brown residue, which upon purification by silica gel column chromatography, afforded 3a (17.4 mg, 53\% yield). Following purification, ${ }^{1} \mathrm{H}$ NMR analysis revealed that the sample contained $<10 \%$ of the semi-reduced alkene byproduct, which could not be separated from the labeled product. (See p. S-83 for comparison.)

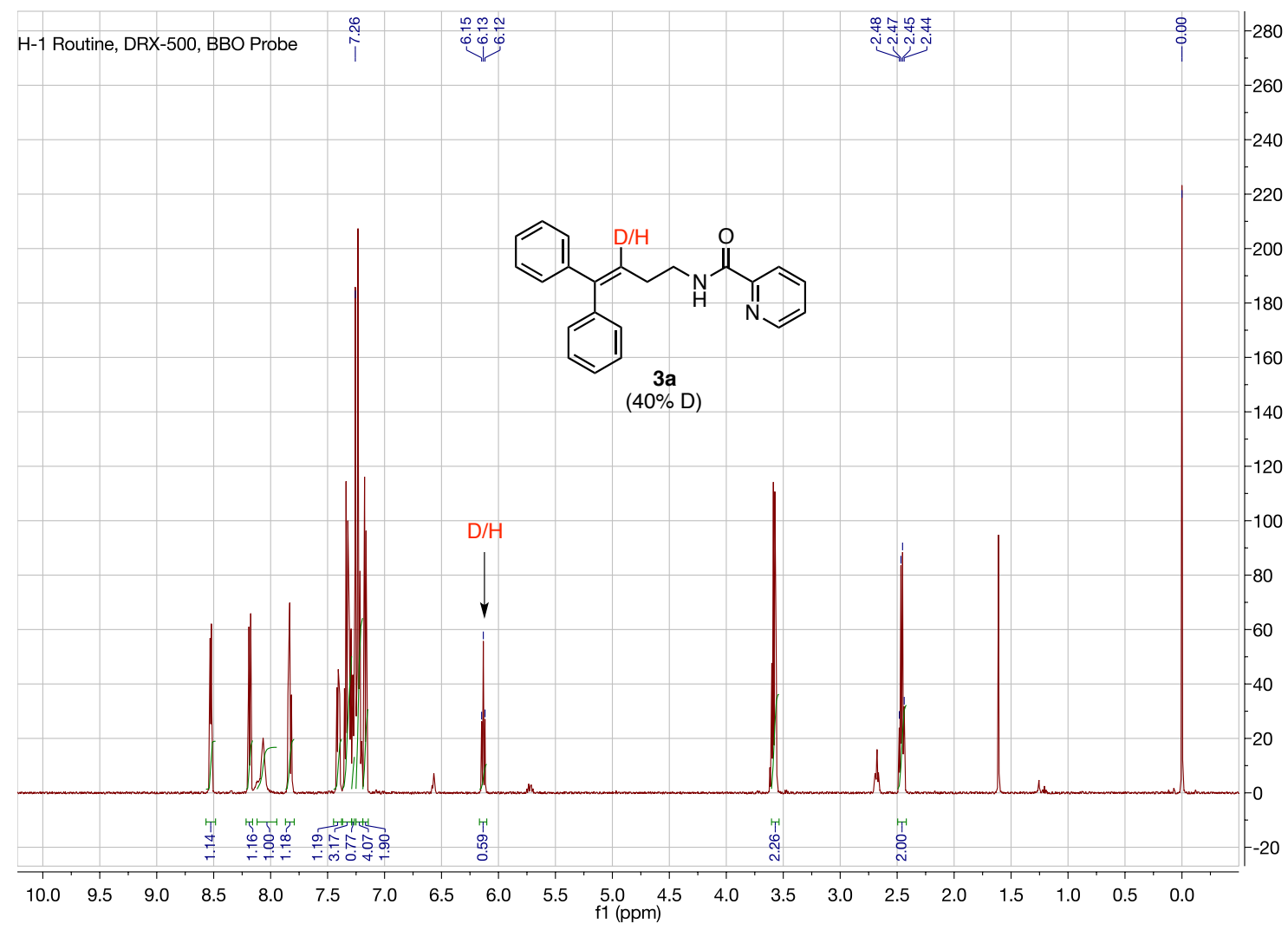




\section{X-RAY CRYSTALLOGRAPHY}

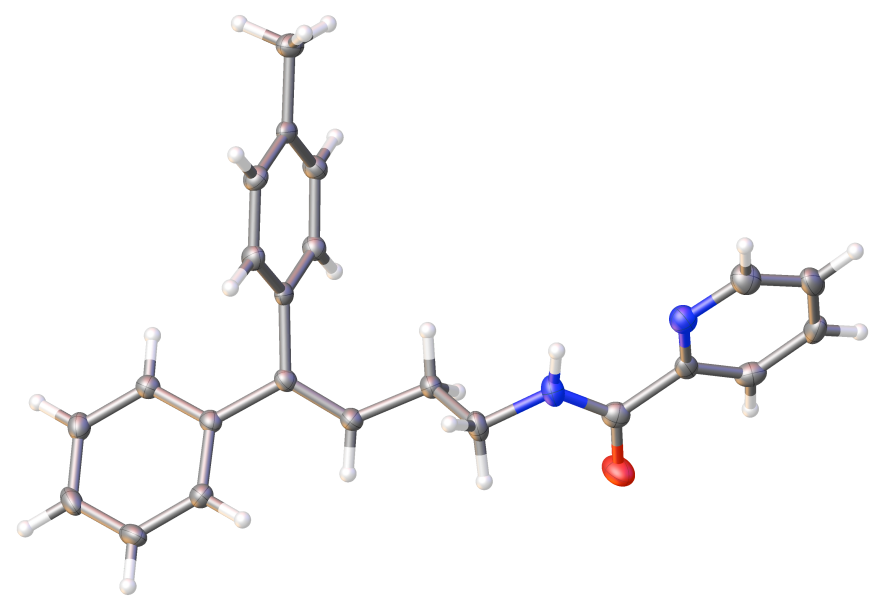

Table S2. Crystal data and structure refinement for $\mathbf{3 b}$.

Identification code

Empirical formula

Formula weight

Temperature

Wavelength

Crystal system

Space group

Unit cell dimensions

Volume

Z

Density (calculated)

Absorption coefficient

$\mathrm{F}(000)$

Crystal size

Theta range for data collection

Index ranges

Reflections collected

Independent reflections

Completeness to theta $=25.242^{\circ}$

Absorption correction

Max. and min. transmission

Refinement method

Data / restraints / parameters

Goodness-of-fit on $\mathrm{F}^{2}$
LZ-01-C (4-Me)

$\mathrm{C} 23 \mathrm{H} 22 \mathrm{~N} 2 \mathrm{O}$

342.42

$100.0 \mathrm{~K}$

$0.71073 \AA$

Triclinic

P-1

$\mathrm{a}=9.5297(5) \AA$

$\alpha=79.725(2)^{\circ}$.

$\mathrm{b}=9.8101(7) \AA$

$\beta=84.919(2)^{\circ}$.

$\mathrm{c}=9.8488(6) \AA$

$\gamma=89.558(2)^{\circ}$.

$902.38(10) \AA^{3}$

2

$1.260 \mathrm{Mg} / \mathrm{m}^{3}$

$0.078 \mathrm{~mm}^{-1}$

364

$0.3 \times 0.25 \times 0.22 \mathrm{~mm}^{3}$

2.110 to $26.417^{\circ}$.

$-11<=\mathrm{h}<=10,-12<=\mathrm{k}<=12,-12<=1<=12$

21585

$3700[\mathrm{R}(\mathrm{int})=0.0619]$

$100.0 \%$

Semi-empirical from equivalents

0.2586 and 0.2277

Full-matrix least-squares on $\mathrm{F}^{2}$

3700 / 0 / 236

1.054 
Final $\mathrm{R}$ indices [I $>2 \operatorname{sigma}(\mathrm{I})]$

$\mathrm{R}$ indices (all data)

Extinction coefficient

Largest diff. peak and hole
$\mathrm{R} 1=0.0514, \mathrm{wR} 2=0.1317$

$\mathrm{R} 1=0.0627, \mathrm{wR} 2=0.1410$

$\mathrm{n} / \mathrm{a}$

0.790 and -0.331 e. $\AA^{-3}$ 
Table S3. Atomic coordinates ( $\times 10^{4}$ ) and equivalent isotropic displacement parameters $\left(\AA^{2} \times 10^{3}\right)$ for $3 \mathbf{b} . \mathrm{U}(\mathrm{eq})$ is defined as one third of the trace of the orthogonalized $\mathrm{U}^{\mathrm{ij}}$ tensor.

\begin{tabular}{|c|c|c|c|c|}
\hline & $\mathrm{x}$ & $\mathrm{y}$ & $\mathrm{z}$ & $\mathrm{U}(\mathrm{eq})$ \\
\hline $\mathrm{O}(1)$ & $10888(1)$ & $4035(1)$ & $-2246(2)$ & $36(1)$ \\
\hline $\mathrm{N}(1)$ & $10284(2)$ & $2087(2)$ & $-724(2)$ & $26(1)$ \\
\hline $\mathrm{N}(2)$ & $12837(2)$ & $1004(2)$ & $-1217(2)$ & $26(1)$ \\
\hline $\mathrm{C}(1)$ & $9212(2)$ & $-100(2)$ & $7075(2)$ & $25(1)$ \\
\hline$C(2)$ & $8455(2)$ & $713(2)$ & $5919(2)$ & $19(1)$ \\
\hline C(3) & $8804(2)$ & 2092(2) & $5364(2)$ & $22(1)$ \\
\hline$C(4)$ & $8124(2)$ & 2812(2) & $4260(2)$ & 21(1) \\
\hline$C(5)$ & 7061(2) & $2179(2)$ & $3698(2)$ & $18(1)$ \\
\hline$C(6)$ & $6366(2)$ & $2927(2)$ & $2479(2)$ & $18(1)$ \\
\hline$C(7)$ & $7089(2)$ & $3356(2)$ & $1249(2)$ & 21(1) \\
\hline$C(8)$ & $8615(2)$ & $3092(2)$ & $875(2)$ & $22(1)$ \\
\hline $\mathrm{C}(9)$ & $8814(2)$ & $2434(2)$ & $-412(2)$ & $26(1)$ \\
\hline$C(10)$ & 11190(2) & $2907(2)$ & $-1587(2)$ & $24(1)$ \\
\hline $\mathrm{C}(11)$ & $12671(2)$ & $2345(2)$ & $-1699(2)$ & $21(1)$ \\
\hline$C(12)$ & $14128(2)$ & $505(2)$ & $-1349(2)$ & $31(1)$ \\
\hline$C(13)$ & $15294(2)$ & $1302(2)$ & $-1917(2)$ & $31(1)$ \\
\hline$C(14)$ & $7377(2)$ & $95(2)$ & $5367(2)$ & 21(1) \\
\hline$C(15)$ & $6678(2)$ & $819(2)$ & 4291(2) & 21(1) \\
\hline$C(16)$ & $4836(2)$ & $3240(2)$ & $2689(2)$ & $18(1)$ \\
\hline$C(17)$ & $3953(2)$ & $3321(2)$ & $1618(2)$ & $22(1)$ \\
\hline $\mathrm{C}(18)$ & $2559(2)$ & $3706(2)$ & 1801(2) & $26(1)$ \\
\hline C(19) & 2004(2) & $4006(2)$ & $3066(2)$ & $27(1)$ \\
\hline $\mathrm{C}(20)$ & $2850(2)$ & $3897(2)$ & $4152(2)$ & $24(1)$ \\
\hline$C(21)$ & $4253(2)$ & $3511(2)$ & $3967(2)$ & 21(1) \\
\hline$C(22)$ & $13777(2)$ & $3242(2)$ & $-2293(2)$ & $27(1)$ \\
\hline$C(23)$ & $15133(2)$ & $2699(2)$ & $-2388(2)$ & $29(1)$ \\
\hline
\end{tabular}


Table S4. Bond lengths $[\AA]$ and angles $\left[{ }^{\circ}\right]$ for $\mathbf{3 b}$.

\begin{tabular}{ll}
\hline $\mathrm{O}(1)-\mathrm{C}(10)$ & $1.225(2)$ \\
$\mathrm{N}(1)-\mathrm{H}(1)$ & 0.8800 \\
$\mathrm{~N}(1)-\mathrm{C}(9)$ & $1.458(2)$ \\
$\mathrm{N}(1)-\mathrm{C}(10)$ & $1.323(2)$ \\
$\mathrm{N}(2)-\mathrm{C}(11)$ & $1.330(2)$ \\
$\mathrm{N}(2)-\mathrm{C}(12)$ & $1.325(2)$ \\
$\mathrm{C}(1)-\mathrm{H}(1 \mathrm{~A})$ & 0.9800 \\
$\mathrm{C}(1)-\mathrm{H}(1 \mathrm{~B})$ & 0.9800 \\
$\mathrm{C}(1)-\mathrm{H}(1 \mathrm{C})$ & 0.9800 \\
$\mathrm{C}(1)-\mathrm{C}(2)$ & $1.505(2)$ \\
$\mathrm{C}(2)-\mathrm{C}(3)$ & $1.397(2)$ \\
$\mathrm{C}(2)-\mathrm{C}(14)$ & $1.395(2)$ \\
$\mathrm{C}(3)-\mathrm{H}(3)$ & 0.9500 \\
$\mathrm{C}(3)-\mathrm{C}(4)$ & $1.394(2)$ \\
$\mathrm{C}(4)-\mathrm{H}(4)$ & 0.9500 \\
$\mathrm{C}(4)-\mathrm{C}(5)$ & $1.397(2)$ \\
$\mathrm{C}(5)-\mathrm{C}(6)$ & $1.496(2)$ \\
$\mathrm{C}(5)-\mathrm{C}(15)$ & $1.395(2)$ \\
$\mathrm{C}(6)-\mathrm{C}(7)$ & $1.340(2)$ \\
$\mathrm{C}(6)-\mathrm{C}(16)$ & $1.492(2)$ \\
$\mathrm{C}(7)-\mathrm{H}(7)$ & 0.9500 \\
$\mathrm{C}(7)-\mathrm{C}(8)$ & $1.500(2)$ \\
$\mathrm{C}(8)-\mathrm{H}(8 \mathrm{~A})$ & 0.9900 \\
$\mathrm{C}(8)-\mathrm{H}(8 \mathrm{~B})$ & 0.9900 \\
$\mathrm{C}(8)-\mathrm{C}(9)$ & $1.519(2)$ \\
$\mathrm{C}(9)-\mathrm{H}(9 \mathrm{~A})$ & 0.9900 \\
$\mathrm{C}(9)-\mathrm{H}(9 \mathrm{~B})$ & 0.9900 \\
$\mathrm{C}(10)-\mathrm{C}(11)$ & $1.513(2)$ \\
$\mathrm{C}(11)-\mathrm{C}(22)$ & $1.395(2)$ \\
$\mathrm{C}(12)-\mathrm{H}(12)$ & 0.9500 \\
$\mathrm{C}(12)-\mathrm{C}(13)$ & $1.381(3)$ \\
& \\
$\mathrm{C}(13)-\mathrm{C}(23)$ & $113)$ \\
& \\
& \\
&
\end{tabular}




\begin{tabular}{|c|c|}
\hline $\mathrm{C}(14)-\mathrm{H}(14)$ & 0.9500 \\
\hline $\mathrm{C}(14)-\mathrm{C}(15)$ & $1.386(2)$ \\
\hline $\mathrm{C}(15)-\mathrm{H}(15)$ & 0.9500 \\
\hline$C(16)-C(17)$ & $1.398(2)$ \\
\hline $\mathrm{C}(16)-\mathrm{C}(21)$ & $1.399(2)$ \\
\hline $\mathrm{C}(17)-\mathrm{H}(17)$ & 0.9500 \\
\hline $\mathrm{C}(17)-\mathrm{C}(18)$ & $1.383(2)$ \\
\hline $\mathrm{C}(18)-\mathrm{H}(18)$ & 0.9500 \\
\hline $\mathrm{C}(18)-\mathrm{C}(19)$ & $1.389(3)$ \\
\hline $\mathrm{C}(19)-\mathrm{H}(19)$ & 0.9500 \\
\hline$C(19)-C(20)$ & $1.385(3)$ \\
\hline $\mathrm{C}(20)-\mathrm{H}(20)$ & 0.9500 \\
\hline$C(20)-C(21)$ & $1.392(2)$ \\
\hline $\mathrm{C}(21)-\mathrm{H}(21)$ & 0.9500 \\
\hline $\mathrm{C}(22)-\mathrm{H}(22)$ & 0.9500 \\
\hline $\mathrm{C}(22)-\mathrm{C}(23)$ & $1.396(3)$ \\
\hline $\mathrm{C}(23)-\mathrm{H}(23)$ & 0.9500 \\
\hline $\mathrm{C}(9)-\mathrm{N}(1)-\mathrm{H}(1)$ & 117.9 \\
\hline $\mathrm{C}(10)-\mathrm{N}(1)-\mathrm{H}(1)$ & 117.9 \\
\hline $\mathrm{C}(10)-\mathrm{N}(1)-\mathrm{C}(9)$ & $124.11(15)$ \\
\hline$C(12)-N(2)-C(11)$ & $117.13(15)$ \\
\hline $\mathrm{H}(1 \mathrm{~A})-\mathrm{C}(1)-\mathrm{H}(1 \mathrm{~B})$ & 109.5 \\
\hline $\mathrm{H}(1 \mathrm{~A})-\mathrm{C}(1)-\mathrm{H}(1 \mathrm{C})$ & 109.5 \\
\hline $\mathrm{H}(1 \mathrm{~B})-\mathrm{C}(1)-\mathrm{H}(1 \mathrm{C})$ & 109.5 \\
\hline $\mathrm{C}(2)-\mathrm{C}(1)-\mathrm{H}(1 \mathrm{~A})$ & 109.5 \\
\hline $\mathrm{C}(2)-\mathrm{C}(1)-\mathrm{H}(1 \mathrm{~B})$ & 109.5 \\
\hline $\mathrm{C}(2)-\mathrm{C}(1)-\mathrm{H}(1 \mathrm{C})$ & 109.5 \\
\hline$C(3)-C(2)-C(1)$ & $121.77(15)$ \\
\hline$C(14)-C(2)-C(1)$ & $120.21(15)$ \\
\hline $\mathrm{C}(14)-\mathrm{C}(2)-\mathrm{C}(3)$ & $118.03(15)$ \\
\hline $\mathrm{C}(2)-\mathrm{C}(3)-\mathrm{H}(3)$ & 119.6 \\
\hline $\mathrm{C}(4)-\mathrm{C}(3)-\mathrm{C}(2)$ & $120.82(15)$ \\
\hline $\mathrm{C}(4)-\mathrm{C}(3)-\mathrm{H}(3)$ & 119.6 \\
\hline $\mathrm{C}(3)-\mathrm{C}(4)-\mathrm{H}(4)$ & 119.6 \\
\hline
\end{tabular}




\begin{tabular}{|c|c|}
\hline$C(3)-C(4)-C(5)$ & $120.79(15)$ \\
\hline $\mathrm{C}(5)-\mathrm{C}(4)-\mathrm{H}(4)$ & 119.6 \\
\hline$C(4)-C(5)-C(6)$ & $121.05(14)$ \\
\hline$C(15)-C(5)-C(4)$ & $118.21(15)$ \\
\hline$C(15)-C(5)-C(6)$ & $120.73(14)$ \\
\hline$C(7)-C(6)-C(5)$ & $121.86(14)$ \\
\hline$C(7)-C(6)-C(16)$ & $120.42(14)$ \\
\hline$C(16)-C(6)-C(5)$ & $117.67(13)$ \\
\hline $\mathrm{C}(6)-\mathrm{C}(7)-\mathrm{H}(7)$ & 116.8 \\
\hline$C(6)-C(7)-C(8)$ & $126.41(15)$ \\
\hline $\mathrm{C}(8)-\mathrm{C}(7)-\mathrm{H}(7)$ & 116.8 \\
\hline $\mathrm{C}(7)-\mathrm{C}(8)-\mathrm{H}(8 \mathrm{~A})$ & 109.3 \\
\hline $\mathrm{C}(7)-\mathrm{C}(8)-\mathrm{H}(8 \mathrm{~B})$ & 109.3 \\
\hline$C(7)-C(8)-C(9)$ & $111.45(14)$ \\
\hline $\mathrm{H}(8 \mathrm{~A})-\mathrm{C}(8)-\mathrm{H}(8 \mathrm{~B})$ & 108.0 \\
\hline $\mathrm{C}(9)-\mathrm{C}(8)-\mathrm{H}(8 \mathrm{~A})$ & 109.3 \\
\hline $\mathrm{C}(9)-\mathrm{C}(8)-\mathrm{H}(8 \mathrm{~B})$ & 109.3 \\
\hline N(1)-C(9)-C(8) & $111.62(14)$ \\
\hline $\mathrm{N}(1)-\mathrm{C}(9)-\mathrm{H}(9 \mathrm{~A})$ & 109.3 \\
\hline $\mathrm{N}(1)-\mathrm{C}(9)-\mathrm{H}(9 \mathrm{~B})$ & 109.3 \\
\hline $\mathrm{C}(8)-\mathrm{C}(9)-\mathrm{H}(9 \mathrm{~A})$ & 109.3 \\
\hline $\mathrm{C}(8)-\mathrm{C}(9)-\mathrm{H}(9 \mathrm{~B})$ & 109.3 \\
\hline $\mathrm{H}(9 \mathrm{~A})-\mathrm{C}(9)-\mathrm{H}(9 \mathrm{~B})$ & 108.0 \\
\hline $\mathrm{O}(1)-\mathrm{C}(10)-\mathrm{N}(1)$ & $124.13(17)$ \\
\hline $\mathrm{O}(1)-\mathrm{C}(10)-\mathrm{C}(11)$ & $121.48(16)$ \\
\hline $\mathrm{N}(1)-\mathrm{C}(10)-\mathrm{C}(11)$ & $114.39(15)$ \\
\hline $\mathrm{N}(2)-\mathrm{C}(11)-\mathrm{C}(10)$ & $117.15(15)$ \\
\hline $\mathrm{N}(2)-\mathrm{C}(11)-\mathrm{C}(22)$ & $123.70(16)$ \\
\hline $\mathrm{C}(22)-\mathrm{C}(11)-\mathrm{C}(10)$ & $119.15(16)$ \\
\hline $\mathrm{N}(2)-\mathrm{C}(12)-\mathrm{H}(12)$ & 118.1 \\
\hline $\mathrm{N}(2)-\mathrm{C}(12)-\mathrm{C}(13)$ & $123.76(18)$ \\
\hline $\mathrm{C}(13)-\mathrm{C}(12)-\mathrm{H}(12)$ & 118.1 \\
\hline $\mathrm{C}(12)-\mathrm{C}(13)-\mathrm{H}(13)$ & 120.3 \\
\hline$C(23)-C(13)-C(12)$ & $119.32(17)$ \\
\hline $\mathrm{C}(23)-\mathrm{C}(13)-\mathrm{H}(13)$ & 120.3 \\
\hline
\end{tabular}




\begin{tabular}{|c|c|}
\hline $\mathrm{C}(2)-\mathrm{C}(14)-\mathrm{H}(14)$ & 119.4 \\
\hline$C(15)-C(14)-C(2)$ & $121.19(15)$ \\
\hline $\mathrm{C}(15)-\mathrm{C}(14)-\mathrm{H}(14)$ & 119.4 \\
\hline $\mathrm{C}(5)-\mathrm{C}(15)-\mathrm{H}(15)$ & 119.6 \\
\hline$C(14)-C(15)-C(5)$ & $120.89(15)$ \\
\hline $\mathrm{C}(14)-\mathrm{C}(15)-\mathrm{H}(15)$ & 119.6 \\
\hline$C(17)-C(16)-C(6)$ & $121.71(14)$ \\
\hline $\mathrm{C}(17)-\mathrm{C}(16)-\mathrm{C}(21)$ & $117.91(15)$ \\
\hline$C(21)-C(16)-C(6)$ & $120.34(14)$ \\
\hline $\mathrm{C}(16)-\mathrm{C}(17)-\mathrm{H}(17)$ & 119.5 \\
\hline $\mathrm{C}(18)-\mathrm{C}(17)-\mathrm{C}(16)$ & $121.00(16)$ \\
\hline $\mathrm{C}(18)-\mathrm{C}(17)-\mathrm{H}(17)$ & 119.5 \\
\hline $\mathrm{C}(17)-\mathrm{C}(18)-\mathrm{H}(18)$ & 119.8 \\
\hline $\mathrm{C}(17)-\mathrm{C}(18)-\mathrm{C}(19)$ & $120.42(16)$ \\
\hline $\mathrm{C}(19)-\mathrm{C}(18)-\mathrm{H}(18)$ & 119.8 \\
\hline $\mathrm{C}(18)-\mathrm{C}(19)-\mathrm{H}(19)$ & 120.2 \\
\hline $\mathrm{C}(20)-\mathrm{C}(19)-\mathrm{C}(18)$ & $119.53(16)$ \\
\hline $\mathrm{C}(20)-\mathrm{C}(19)-\mathrm{H}(19)$ & 120.2 \\
\hline $\mathrm{C}(19)-\mathrm{C}(20)-\mathrm{H}(20)$ & 120.0 \\
\hline$C(19)-C(20)-C(21)$ & $120.05(16)$ \\
\hline $\mathrm{C}(21)-\mathrm{C}(20)-\mathrm{H}(20)$ & 120.0 \\
\hline $\mathrm{C}(16)-\mathrm{C}(21)-\mathrm{H}(21)$ & 119.5 \\
\hline$C(20)-C(21)-C(16)$ & $121.05(16)$ \\
\hline $\mathrm{C}(20)-\mathrm{C}(21)-\mathrm{H}(21)$ & 119.5 \\
\hline $\mathrm{C}(11)-\mathrm{C}(22)-\mathrm{H}(22)$ & 120.9 \\
\hline$C(11)-C(22)-C(23)$ & $118.11(16)$ \\
\hline $\mathrm{C}(23)-\mathrm{C}(22)-\mathrm{H}(22)$ & 120.9 \\
\hline $\mathrm{C}(13)-\mathrm{C}(23)-\mathrm{C}(22)$ & $117.94(16)$ \\
\hline $\mathrm{C}(13)-\mathrm{C}(23)-\mathrm{H}(23)$ & 121.0 \\
\hline $\mathrm{C}(22)-\mathrm{C}(23)-\mathrm{H}(23)$ & 121.0 \\
\hline
\end{tabular}

Symmetry transformations used to generate equivalent atoms: 
Table S5. Anisotropic displacement parameters $\left(\AA^{2} \times 10^{3}\right)$ for $3 \mathbf{b}$. The anisotropic displacement factor exponent takes the form: $-2 \pi^{2}\left[h^{2} a^{* 2} U^{11}+\ldots+2 h k a^{*} b^{*} U^{12}\right]$

\begin{tabular}{|c|c|c|c|c|c|c|}
\hline & $\mathrm{U}^{11}$ & $\mathrm{U}^{22}$ & $\mathrm{U}^{33}$ & $\mathrm{U}^{23}$ & $\mathrm{U}^{13}$ & $\mathrm{U}^{12}$ \\
\hline $\mathrm{O}(1)$ & $28(1)$ & $30(1)$ & $47(1)$ & $4(1)$ & $-6(1)$ & $5(1)$ \\
\hline $\mathrm{N}(1)$ & 19(1) & $29(1)$ & $31(1)$ & $-8(1)$ & $2(1)$ & 1(1) \\
\hline $\mathrm{N}(2)$ & $26(1)$ & $28(1)$ & $26(1)$ & $-6(1)$ & $-2(1)$ & $1(1)$ \\
\hline$C(1)$ & $26(1)$ & $28(1)$ & $21(1)$ & $-4(1)$ & $-4(1)$ & $7(1)$ \\
\hline$C(2)$ & $18(1)$ & $24(1)$ & $16(1)$ & $-4(1)$ & $1(1)$ & $6(1)$ \\
\hline$C(3)$ & $18(1)$ & $24(1)$ & $23(1)$ & $-5(1)$ & $-4(1)$ & $1(1)$ \\
\hline C(4) & $19(1)$ & $20(1)$ & $22(1)$ & $-3(1)$ & $-1(1)$ & $1(1)$ \\
\hline$C(5)$ & $15(1)$ & $21(1)$ & $16(1)$ & $-4(1)$ & $2(1)$ & $4(1)$ \\
\hline$C(6)$ & $16(1)$ & $19(1)$ & $19(1)$ & $-4(1)$ & $-2(1)$ & $3(1)$ \\
\hline$C(7)$ & $18(1)$ & $23(1)$ & $20(1)$ & $-2(1)$ & $-2(1)$ & $4(1)$ \\
\hline$C(8)$ & $17(1)$ & $28(1)$ & $21(1)$ & $-2(1)$ & $0(1)$ & $3(1)$ \\
\hline $\mathrm{C}(9)$ & $16(1)$ & $34(1)$ & $28(1)$ & $-10(1)$ & $2(1)$ & $1(1)$ \\
\hline$C(10)$ & $26(1)$ & $24(1)$ & $23(1)$ & $-7(1)$ & $-5(1)$ & $0(1)$ \\
\hline $\mathrm{C}(11)$ & 19(1) & $31(1)$ & $16(1)$ & $-9(1)$ & $-2(1)$ & $2(1)$ \\
\hline$C(12)$ & $32(1)$ & $28(1)$ & $33(1)$ & $-10(1)$ & $-2(1)$ & $5(1)$ \\
\hline $\mathrm{C}(13)$ & $22(1)$ & $45(1)$ & $26(1)$ & $-10(1)$ & $-1(1)$ & $10(1)$ \\
\hline$C(14)$ & $23(1)$ & $20(1)$ & $20(1)$ & $-1(1)$ & $0(1)$ & $-1(1)$ \\
\hline$C(15)$ & $18(1)$ & $24(1)$ & $21(1)$ & $-3(1)$ & $-1(1)$ & $-3(1)$ \\
\hline$C(16)$ & $17(1)$ & $17(1)$ & $19(1)$ & $-1(1)$ & $-1(1)$ & $2(1)$ \\
\hline$C(17)$ & $20(1)$ & $27(1)$ & $19(1)$ & $-2(1)$ & $-1(1)$ & $1(1)$ \\
\hline$C(18)$ & $19(1)$ & $32(1)$ & $26(1)$ & $3(1)$ & $-7(1)$ & $0(1)$ \\
\hline$C(19)$ & $15(1)$ & $27(1)$ & $34(1)$ & $3(1)$ & $1(1)$ & $4(1)$ \\
\hline$C(20)$ & $22(1)$ & $25(1)$ & $24(1)$ & $-2(1)$ & $4(1)$ & $3(1)$ \\
\hline $\mathrm{C}(21)$ & $20(1)$ & $24(1)$ & $20(1)$ & $-3(1)$ & $-2(1)$ & $2(1)$ \\
\hline$C(22)$ & $34(1)$ & $26(1)$ & $22(1)$ & $-2(1)$ & $-7(1)$ & $2(1)$ \\
\hline$C(23)$ & $22(1)$ & $45(1)$ & $19(1)$ & $-2(1)$ & $1(1)$ & $-9(1)$ \\
\hline
\end{tabular}


Table S6. Hydrogen coordinates $\left(\times 10^{4}\right)$ and isotropic displacement parameters $\left(\AA^{2} \times 10^{3}\right)$ for $3 \mathbf{b}$.

\begin{tabular}{|c|c|c|c|c|}
\hline & $\mathrm{x}$ & $\mathrm{y}$ & z & $\mathrm{U}(\mathrm{eq})$ \\
\hline $\mathrm{H}(1)$ & 10588 & 1283 & -312 & 32 \\
\hline $\mathrm{H}(1 \mathrm{~A})$ & 8634 & -137 & 7956 & 38 \\
\hline $\mathrm{H}(1 \mathrm{~B})$ & 10116 & 349 & 7122 & 38 \\
\hline $\mathrm{H}(1 \mathrm{C})$ & 9376 & -1044 & 6901 & 38 \\
\hline $\mathrm{H}(3)$ & 9514 & 2546 & 5743 & 26 \\
\hline $\mathrm{H}(4)$ & 8387 & 3745 & 3886 & 25 \\
\hline $\mathrm{H}(7)$ & 6587 & 3879 & 544 & 25 \\
\hline $\mathrm{H}(8 \mathrm{~A})$ & 9001 & 2472 & 1658 & 27 \\
\hline $\mathrm{H}(8 \mathrm{~B})$ & 9146 & 3979 & 709 & 27 \\
\hline $\mathrm{H}(9 \mathrm{~A})$ & 8230 & 1582 & -271 & 31 \\
\hline $\mathrm{H}(9 \mathrm{~B})$ & 8490 & 3083 & -1210 & 31 \\
\hline $\mathrm{H}(12)$ & 14259 & -457 & -1035 & 37 \\
\hline $\mathrm{H}(13)$ & 16199 & 892 & -1982 & 37 \\
\hline $\mathrm{H}(14)$ & 7118 & -840 & 5735 & 26 \\
\hline $\mathrm{H}(15)$ & 5928 & 384 & 3952 & 26 \\
\hline $\mathrm{H}(17)$ & 4315 & 3108 & 750 & 27 \\
\hline $\mathrm{H}(18)$ & 1978 & 3766 & 1057 & 32 \\
\hline $\mathrm{H}(19)$ & 1050 & 4283 & 3184 & 32 \\
\hline $\mathrm{H}(20)$ & 2473 & 4086 & 5024 & 29 \\
\hline $\mathrm{H}(21)$ & 4824 & 3432 & 4720 & 25 \\
\hline $\mathrm{H}(22)$ & 13611 & 4194 & -2623 & 33 \\
\hline $\mathrm{H}(23)$ & 15920 & 3274 & -2766 & 35 \\
\hline
\end{tabular}




\section{REFERENCES}

(1) Zhdanko, A.; Maier, M. M. Angew. Chem. Int. Ed. 2014, 53, 7760.

(2) Leonard, N. M.; Woerpel, K. A. J. Org. Chem. 2009, 74, 6915.

(3) Peng, J.; Chen, C.; Chen, J.; Su, X.; Xi, C.; Chen, H. Org. Lett. 2014, 16, 3776.

(4) Yin, Y.; Ma, W.; Chai, Z.; Zhao, G. J. Org. Chem. 2007, 72, 5731.

(5) García-Rubia, A.; Urones, B.; Arrayás, R. G.; Carretero, J.C. Angew. Chem. 2011, 123, 11119.

(6) Ye, X.; Shi, X. Org. Lett. 2014, 16, 4448.

(7) Karibe, Y.; Kusama, H.; Iwasawa, N. Angew. Chem. Int. Ed. 2012, 51, 6214.

(8) Saito, Y.; Matsumoto, K.; Bag, S. S.; Ogasawara, S.; Fujimoto, K.; Hanawa, K.; Saito, I. Tetrahedron 2008, 64, 3578.

(9) Russell, G. A.; Ros, F. J. Am. Chem. Soc., 1985, 107, 2506.

(10)Rajagopal, B.; Chen, Y.-Y.; Chen, C.-C.; Liu, X.-Y.; Wang, H.-R.; Lin, P.-C. J. Org. Chem. 2014, 79, 1254.

(11)Larsen, C. H.; Anderson, K. W.; Tundel, R. E.; Buchwald, S. L. Synlett 2006, 18, 2941.

(12)CCDC 1465202 (3b) contains the supplementary crystallographic data for this paper. These data can be obtained free of charge from The Cambridge Crystallographic Data Centre via www.ccdc.cam.ac.uk/data request/cif.

(13)Martínez, Á. M.; Echavarren, J.; Alonso, I.; Rodríguez, N.; Arrayás, R. G.; Carretero, J.C. Chem. Sci. 2015, 6, 5802. 


\section{${ }^{1}$ H AND ${ }^{13} \mathrm{C}$ NMR SPECTRA}
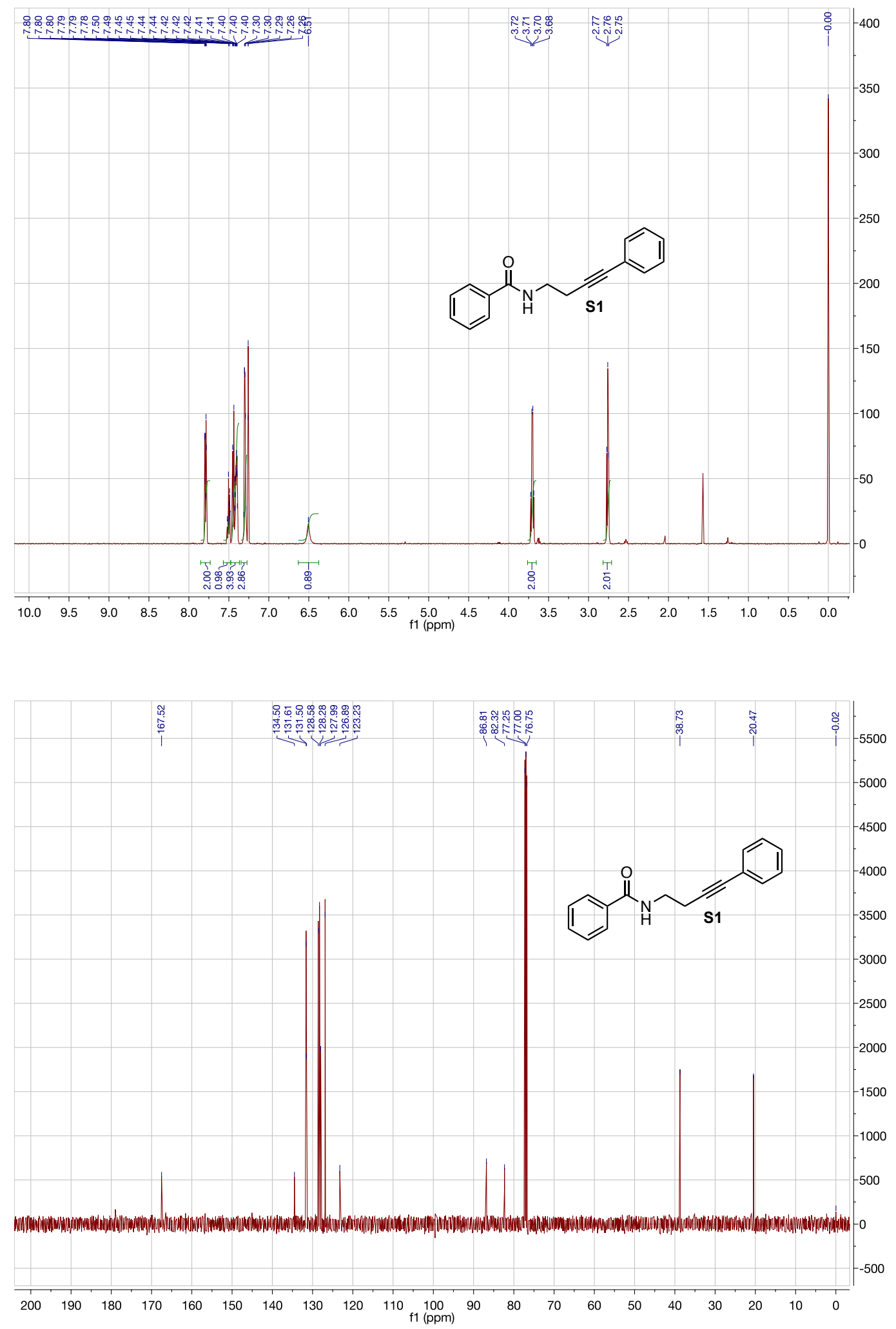

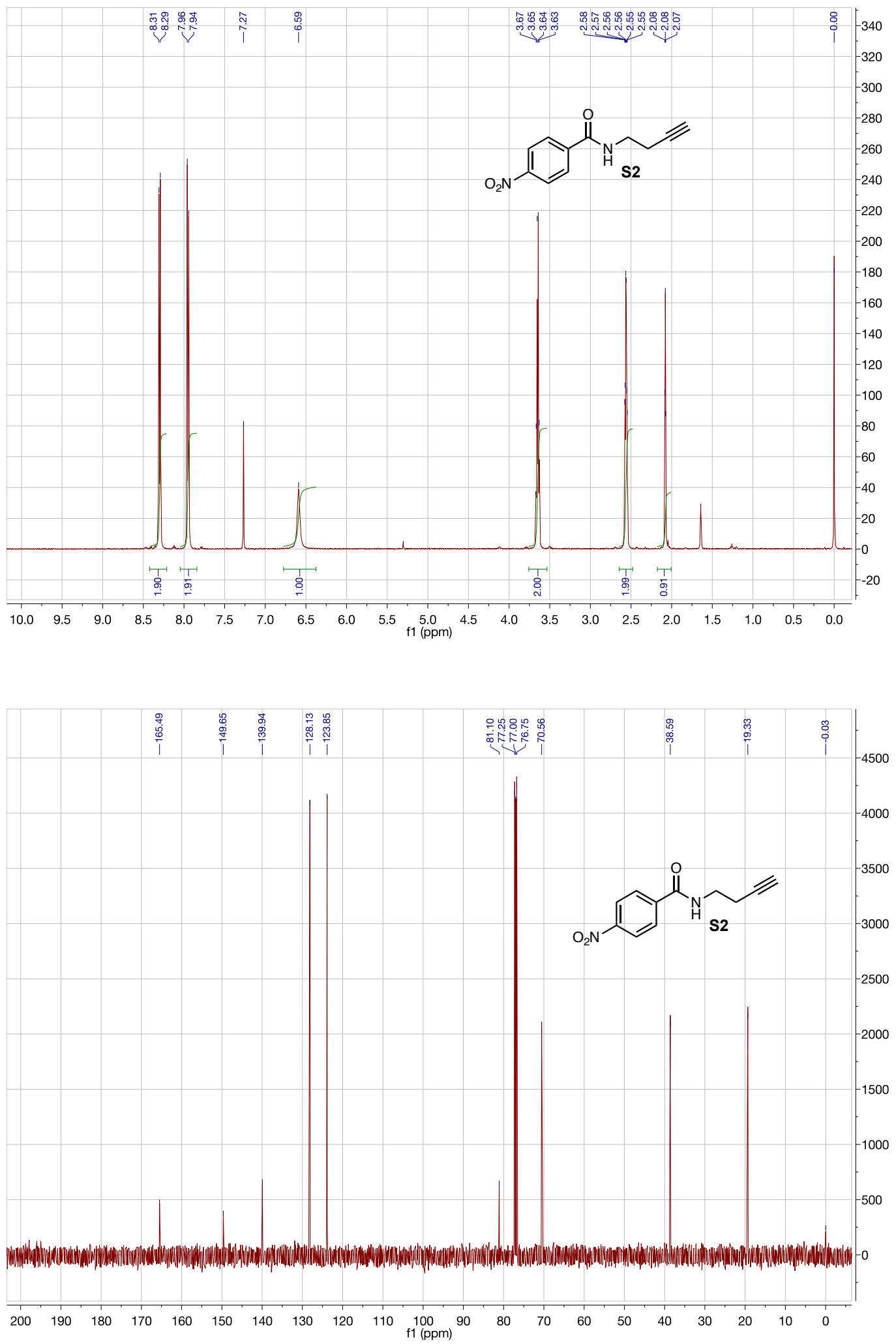

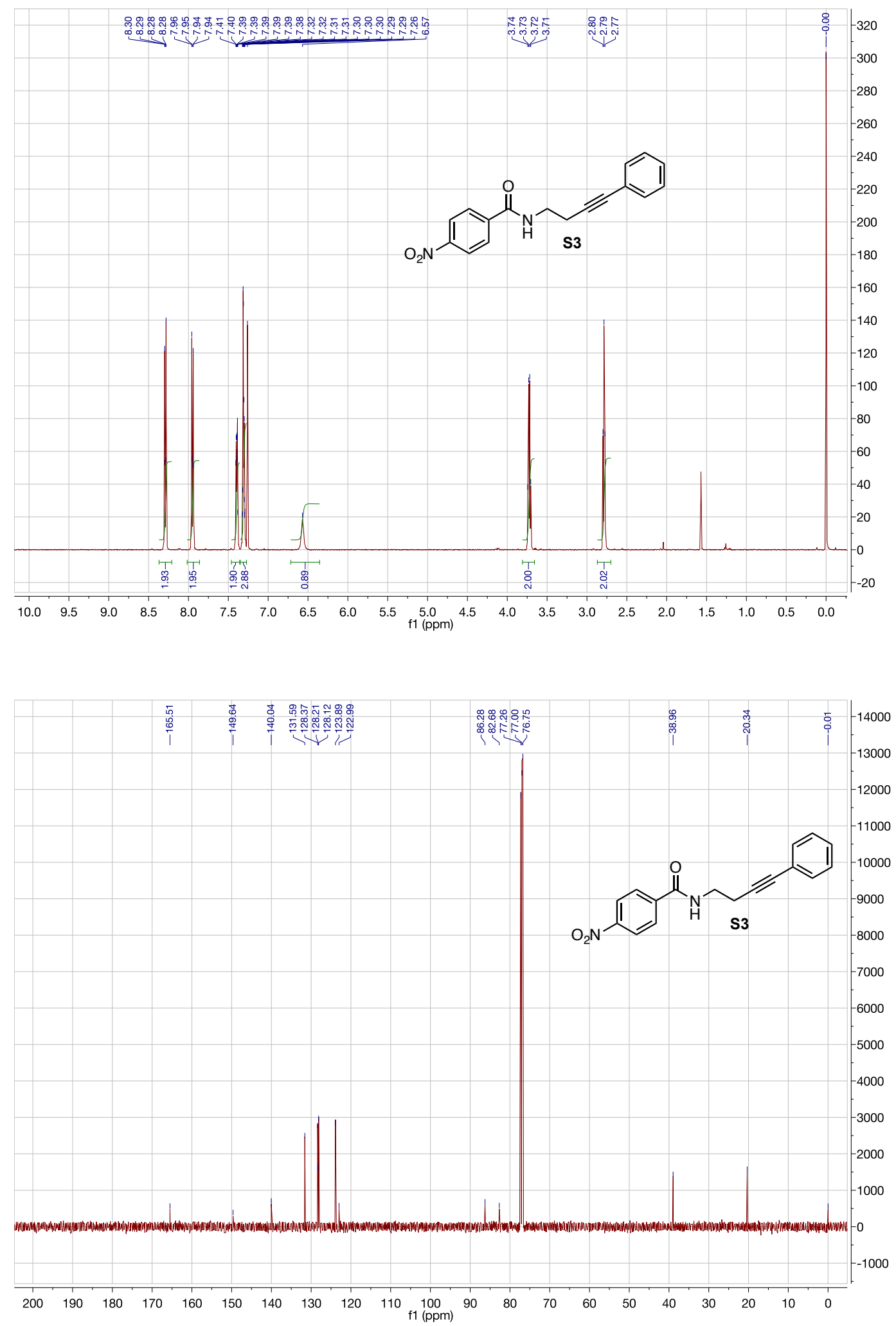

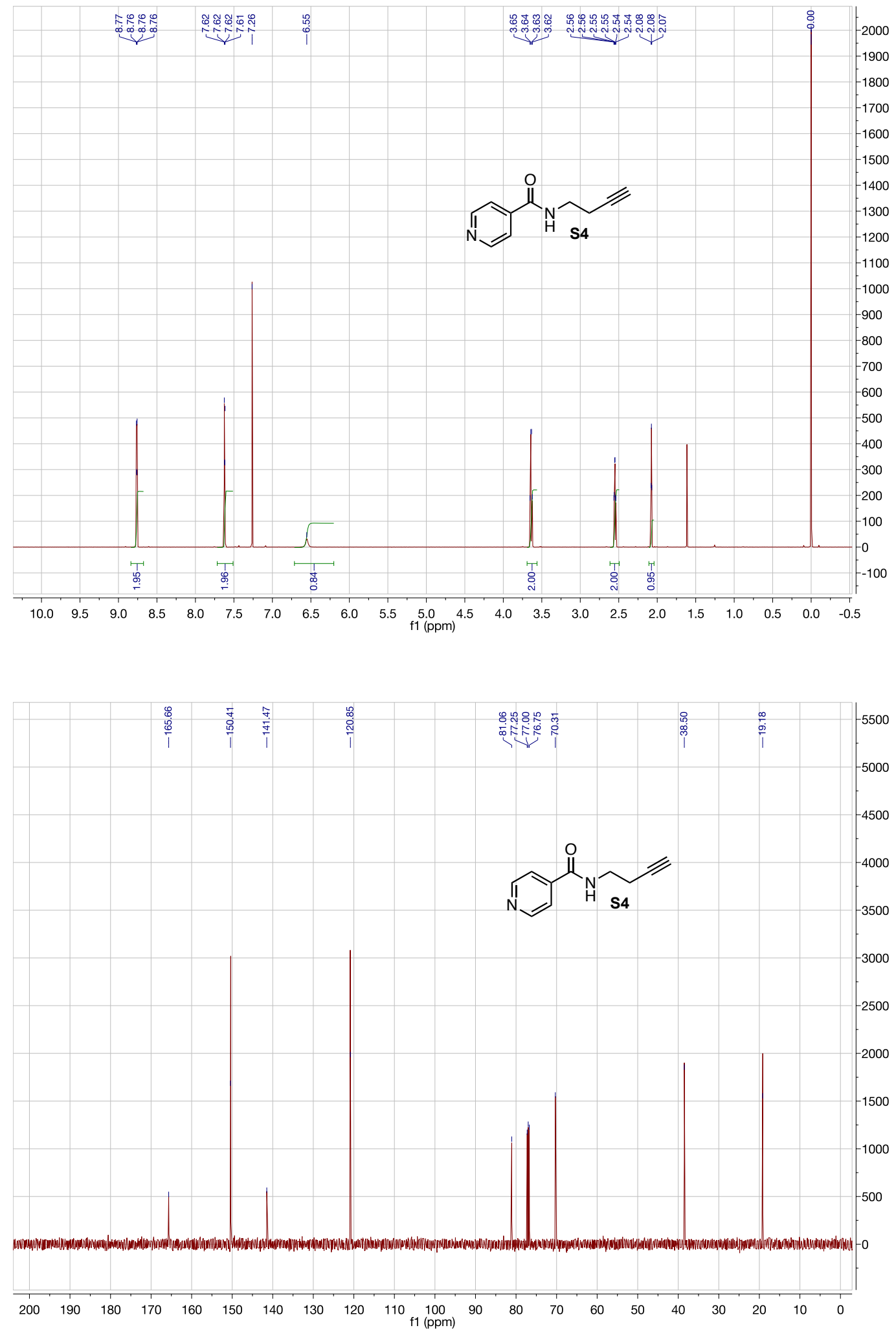

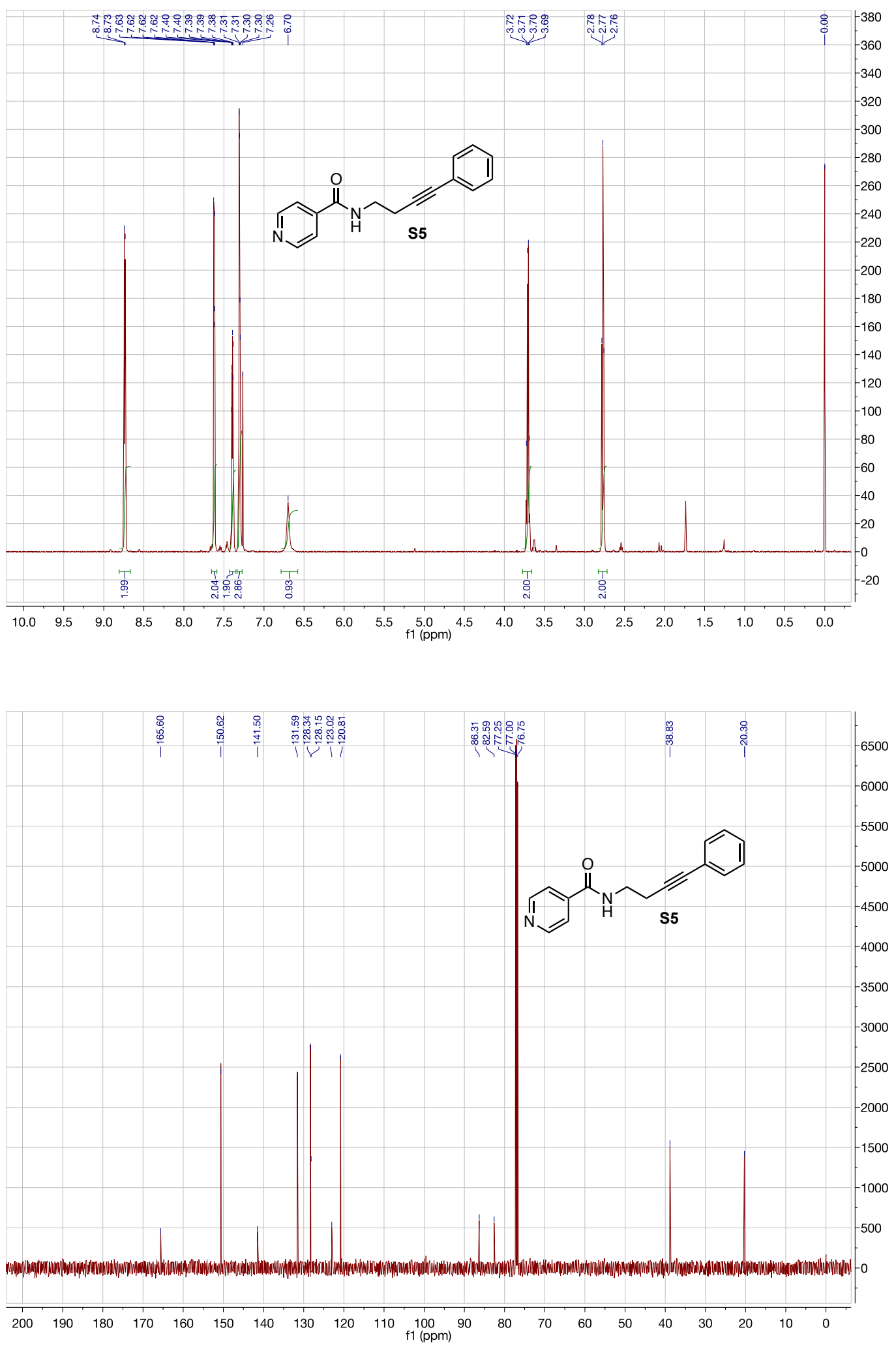

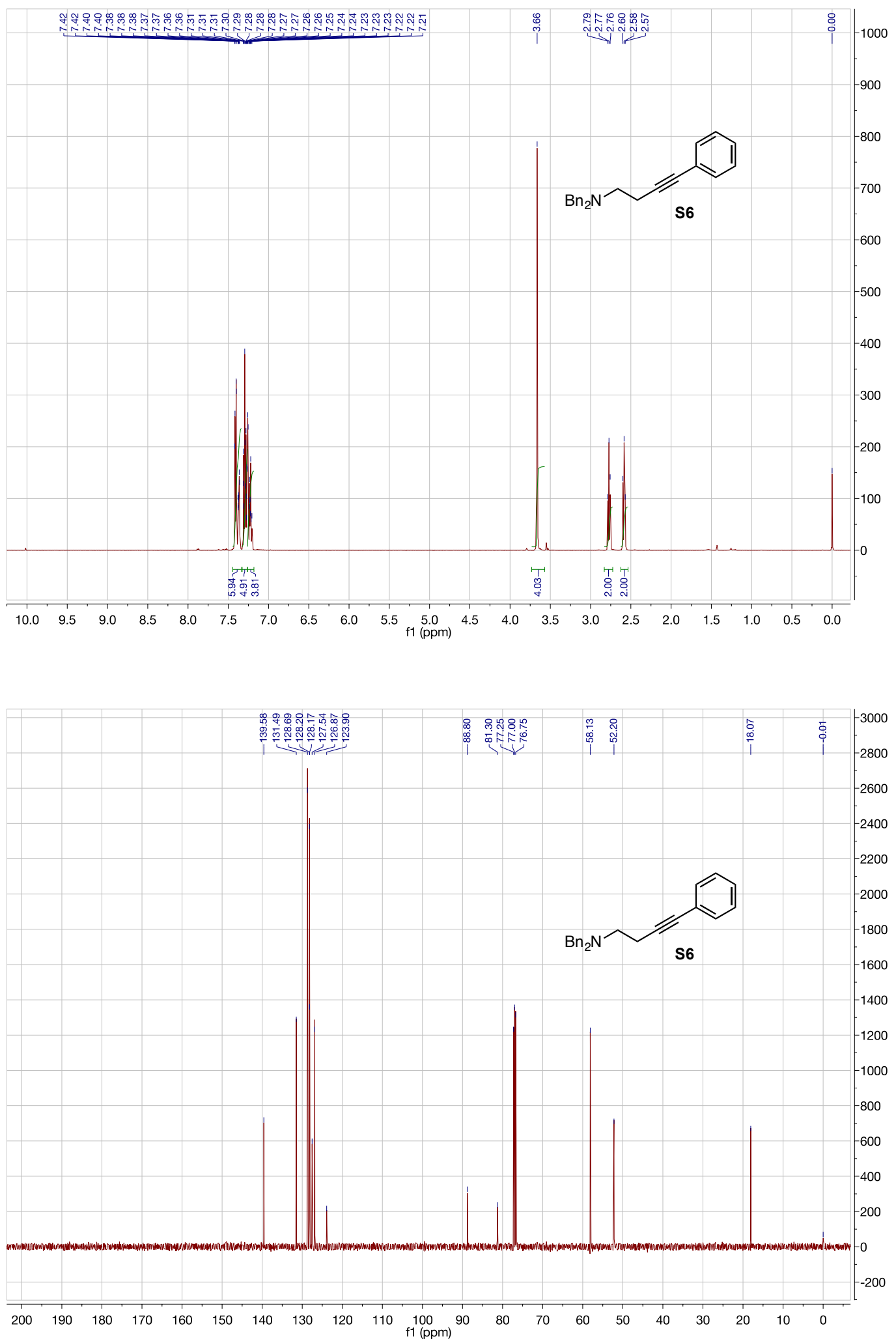

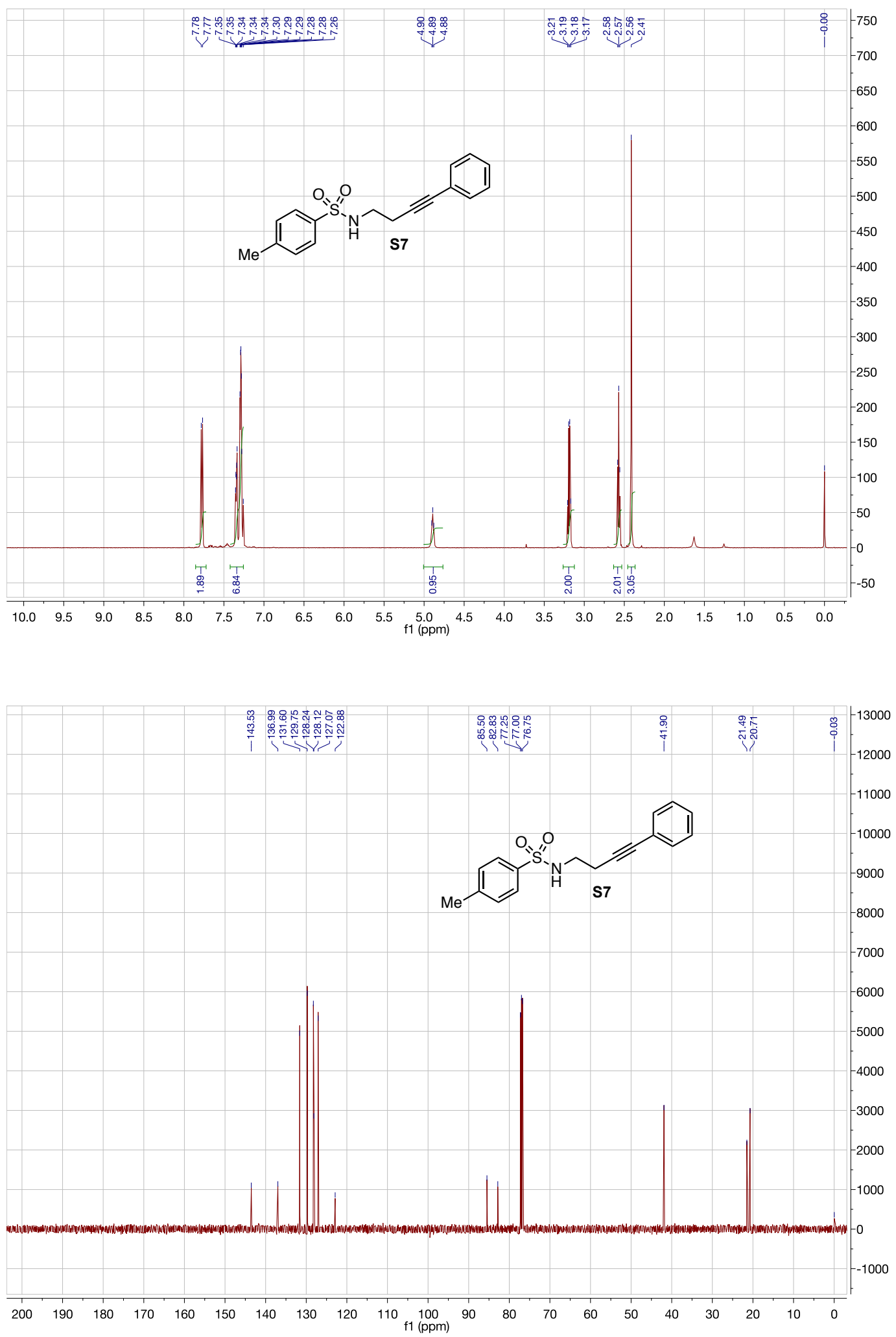

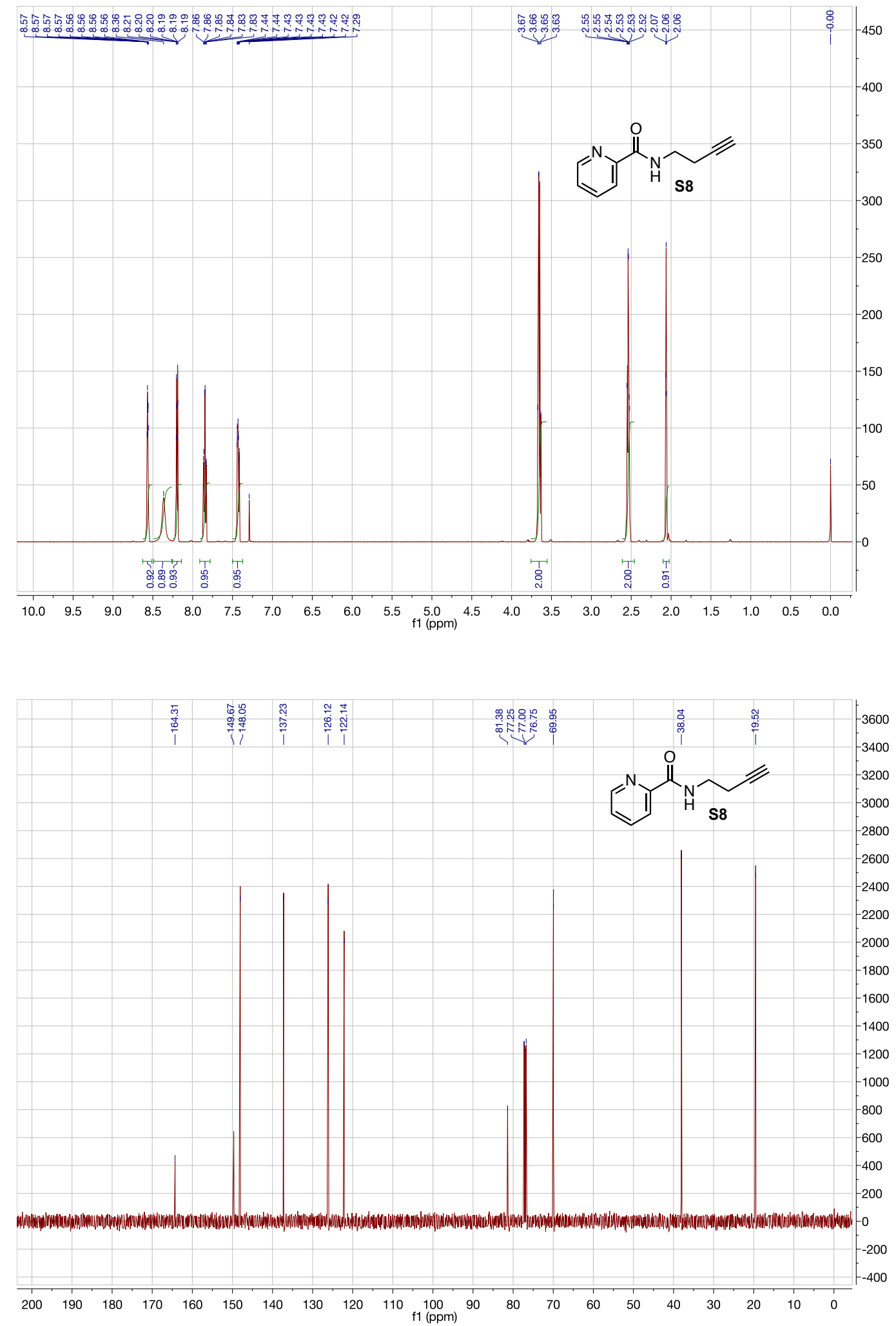

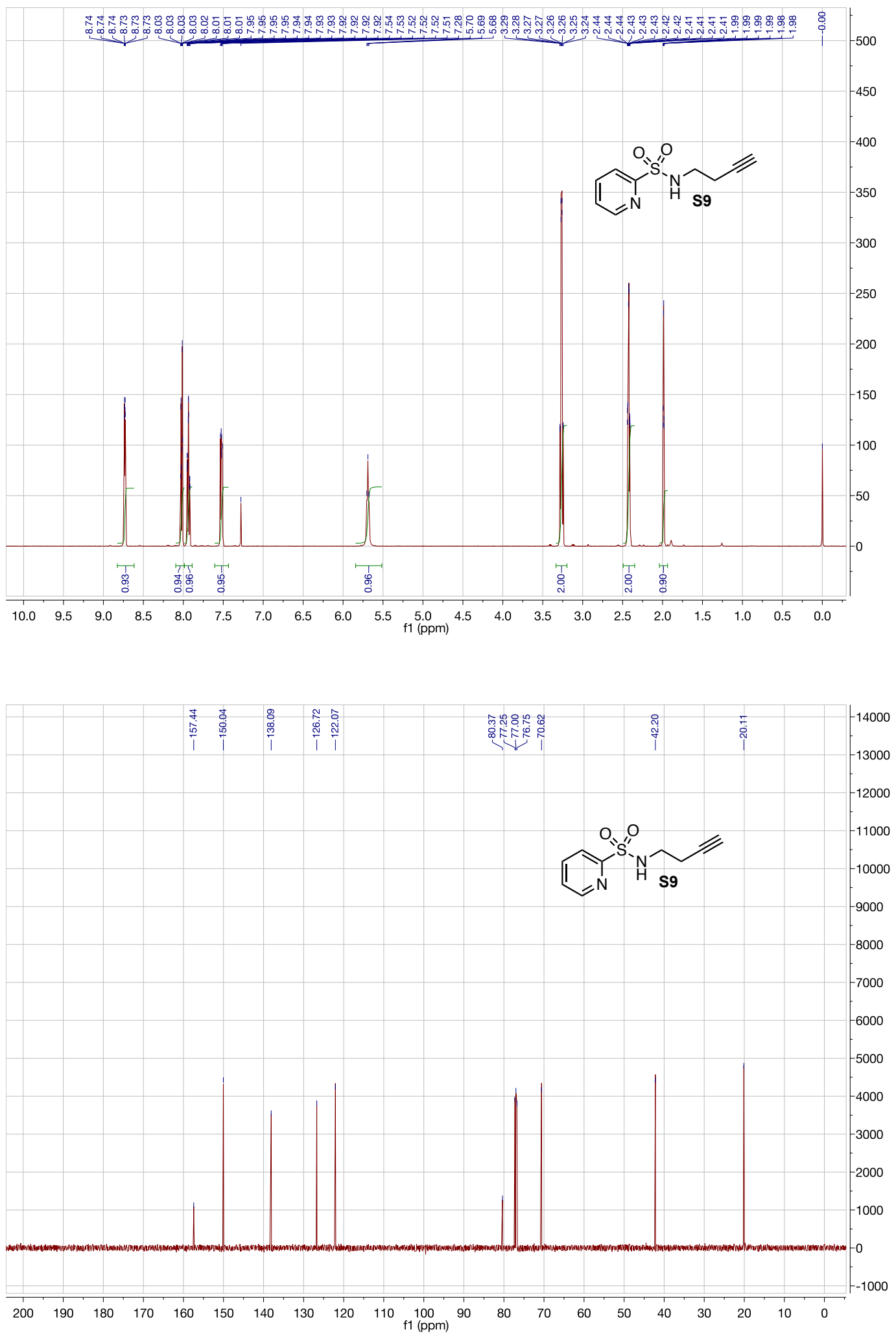

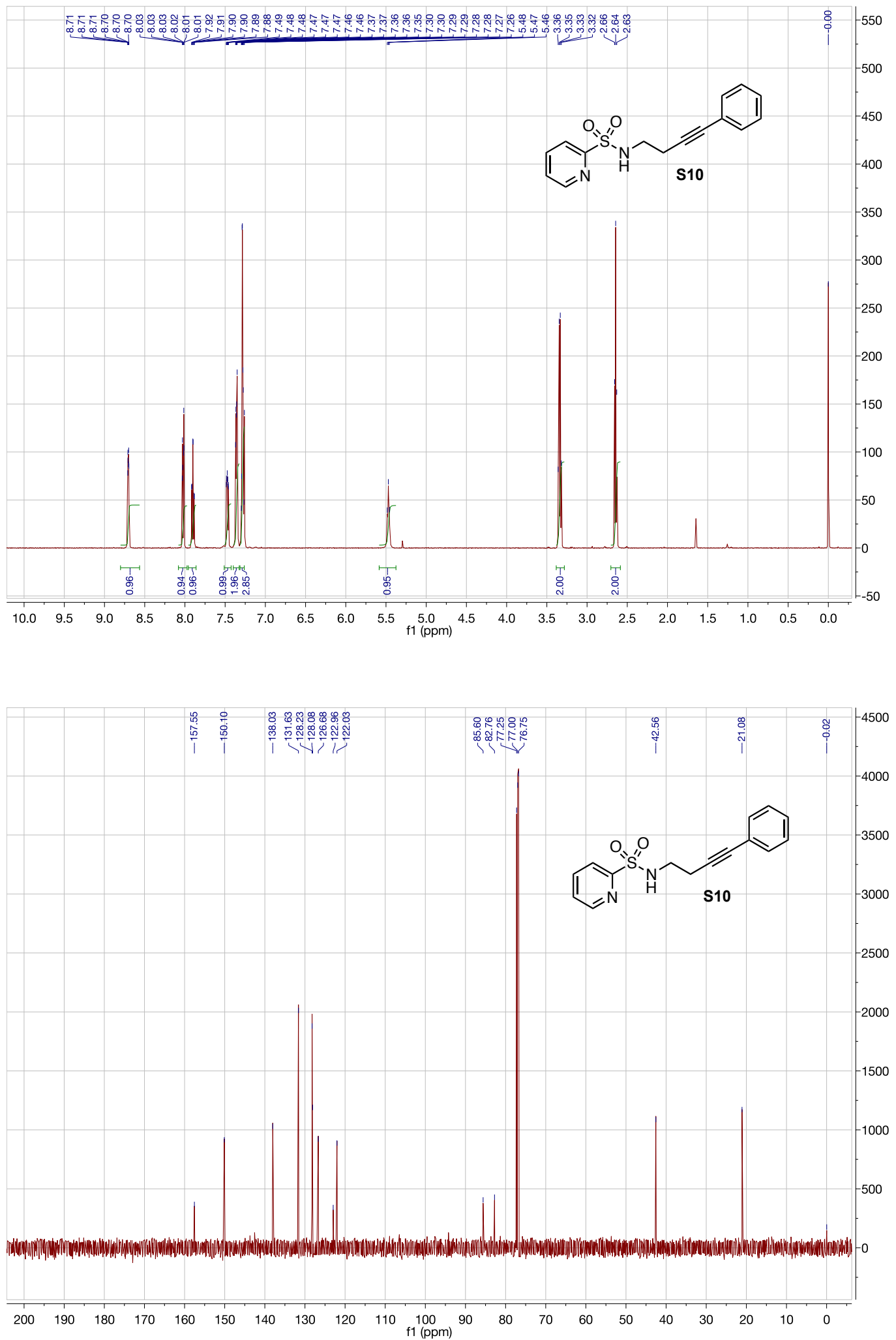

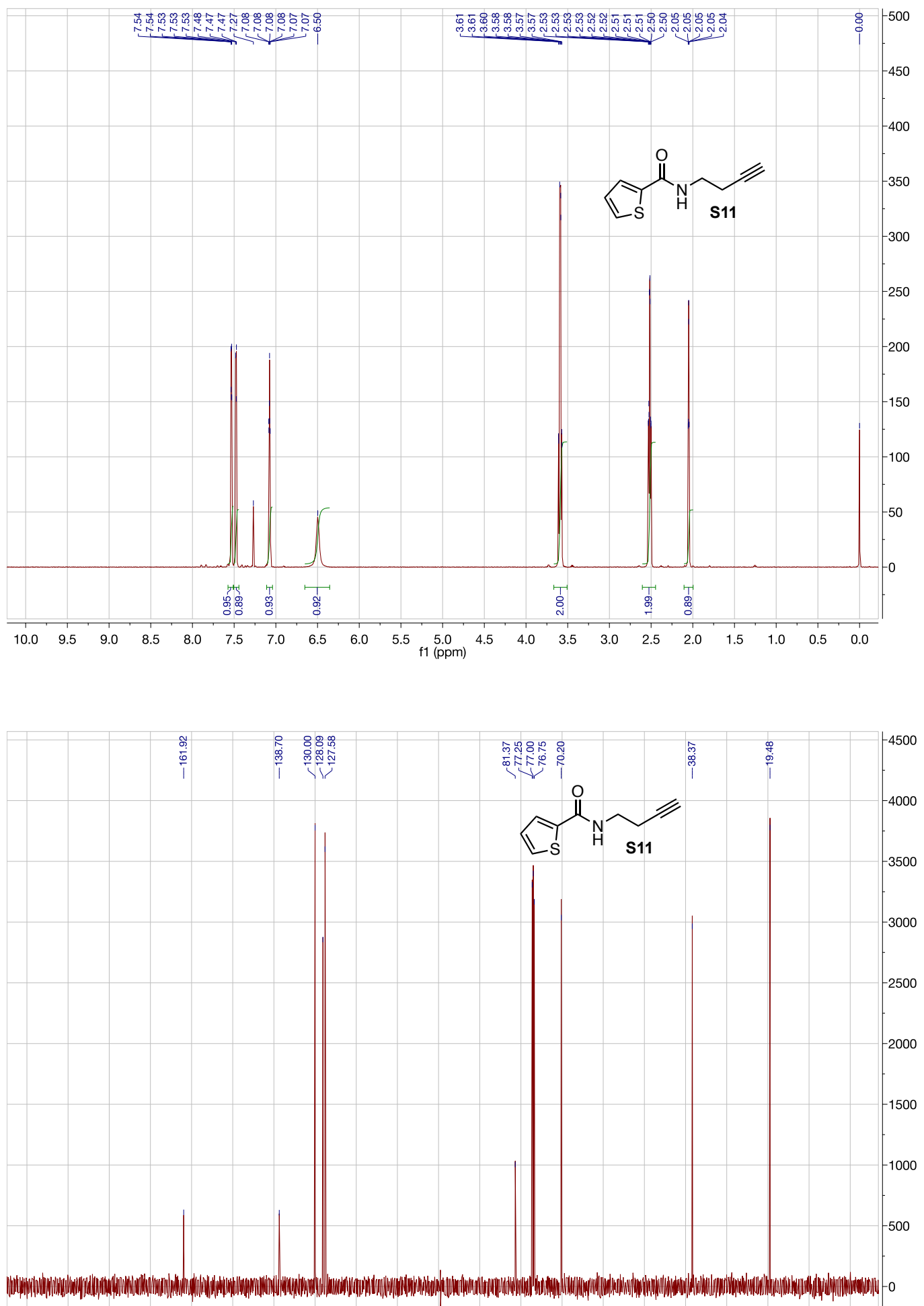

$\begin{array}{lllllllllllllllllllll}200 & 190 & 180 & 170 & 160 & 150 & 140 & 130 & 120 & 110 & 100 & 90 & 80 & 70 & 60 & 50 & 40 & 30 & 20 & 10 & 0\end{array}$ 

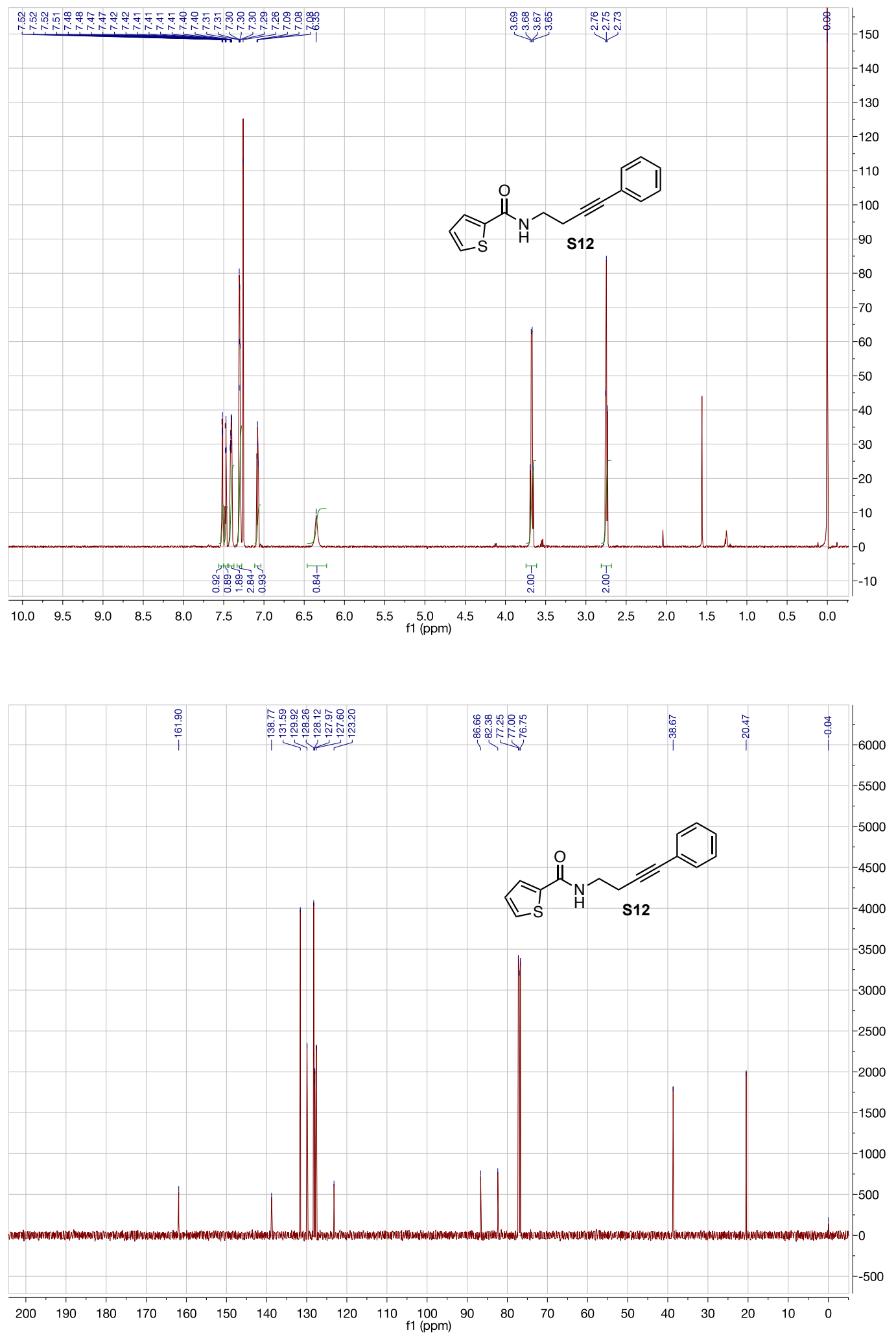

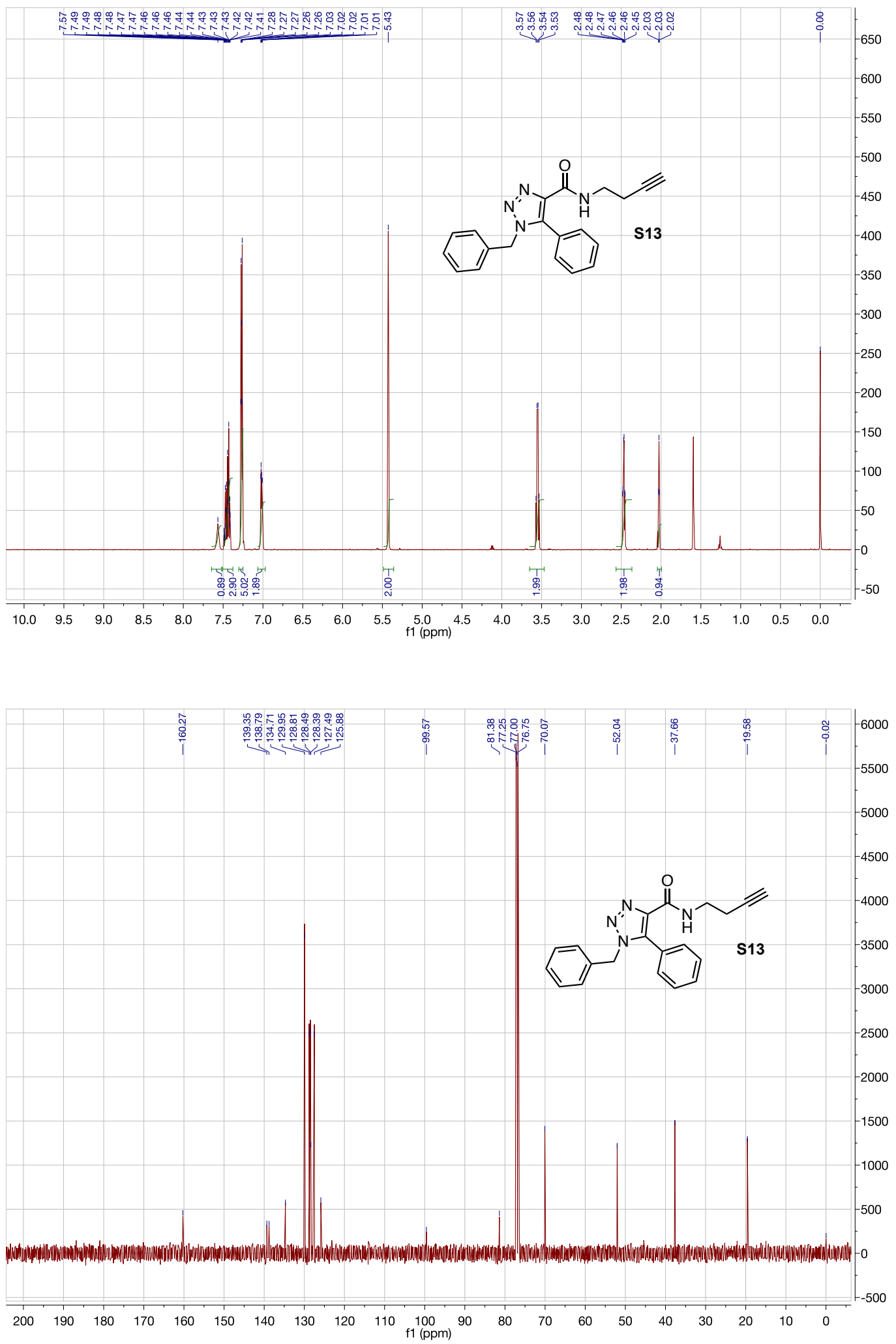

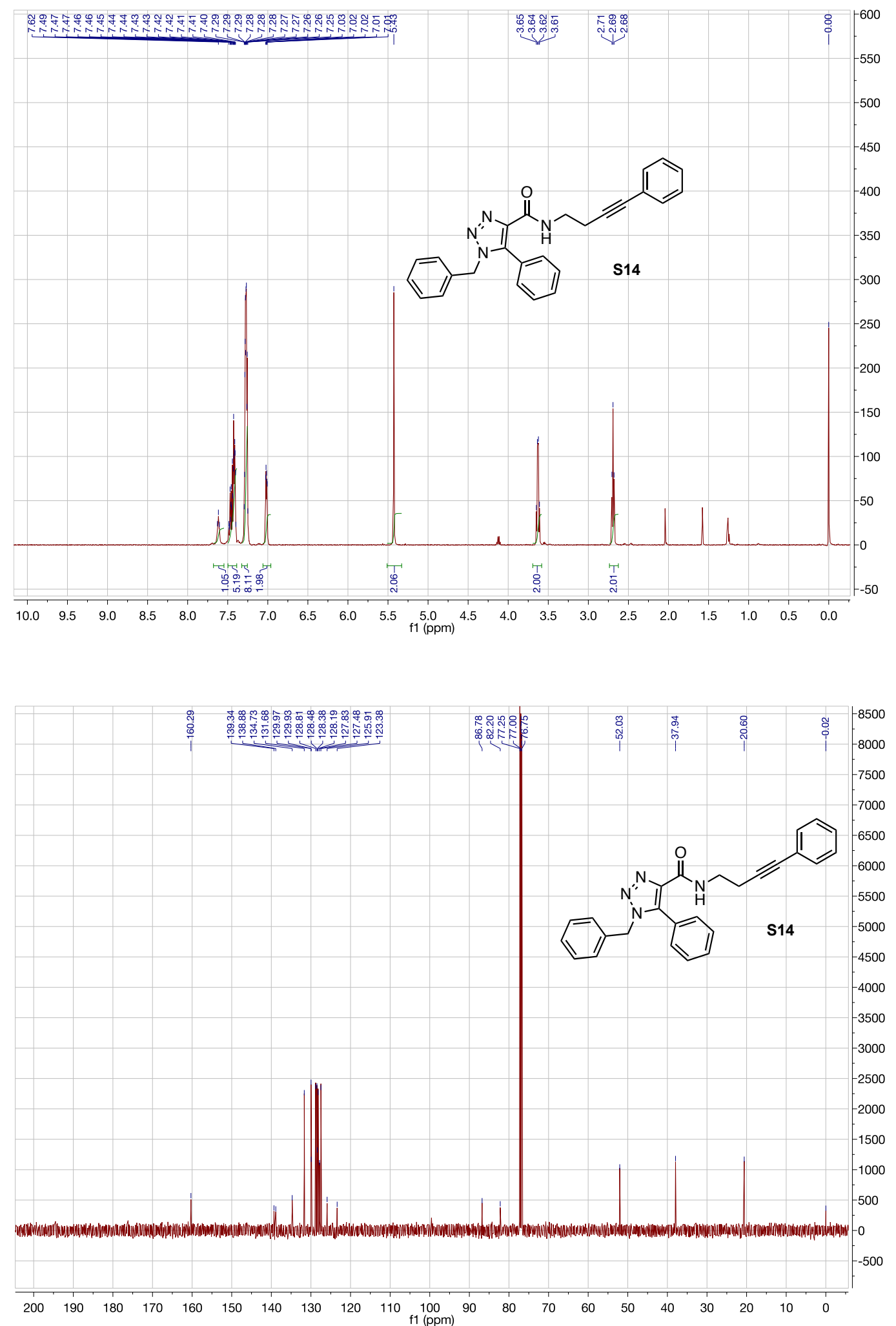

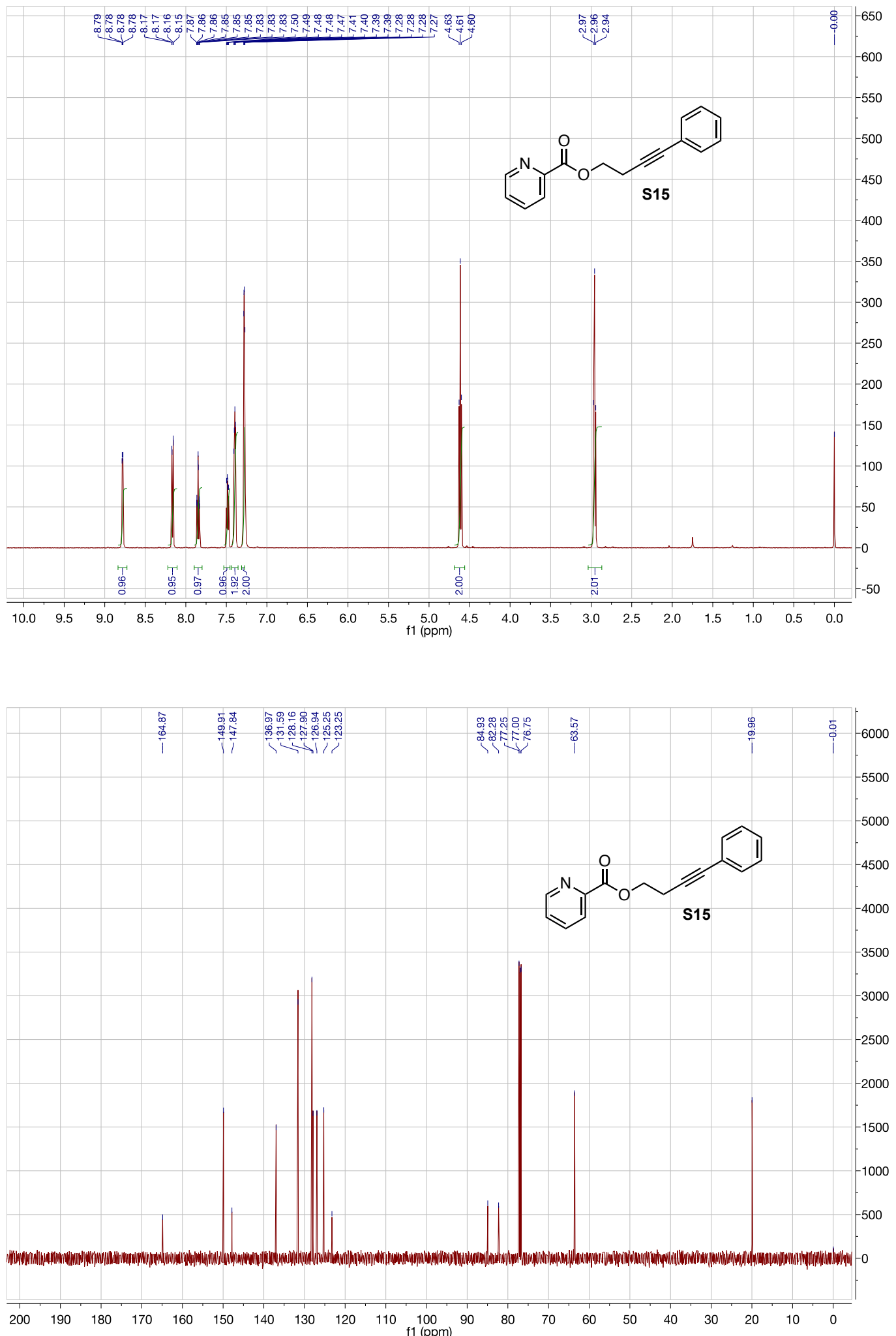

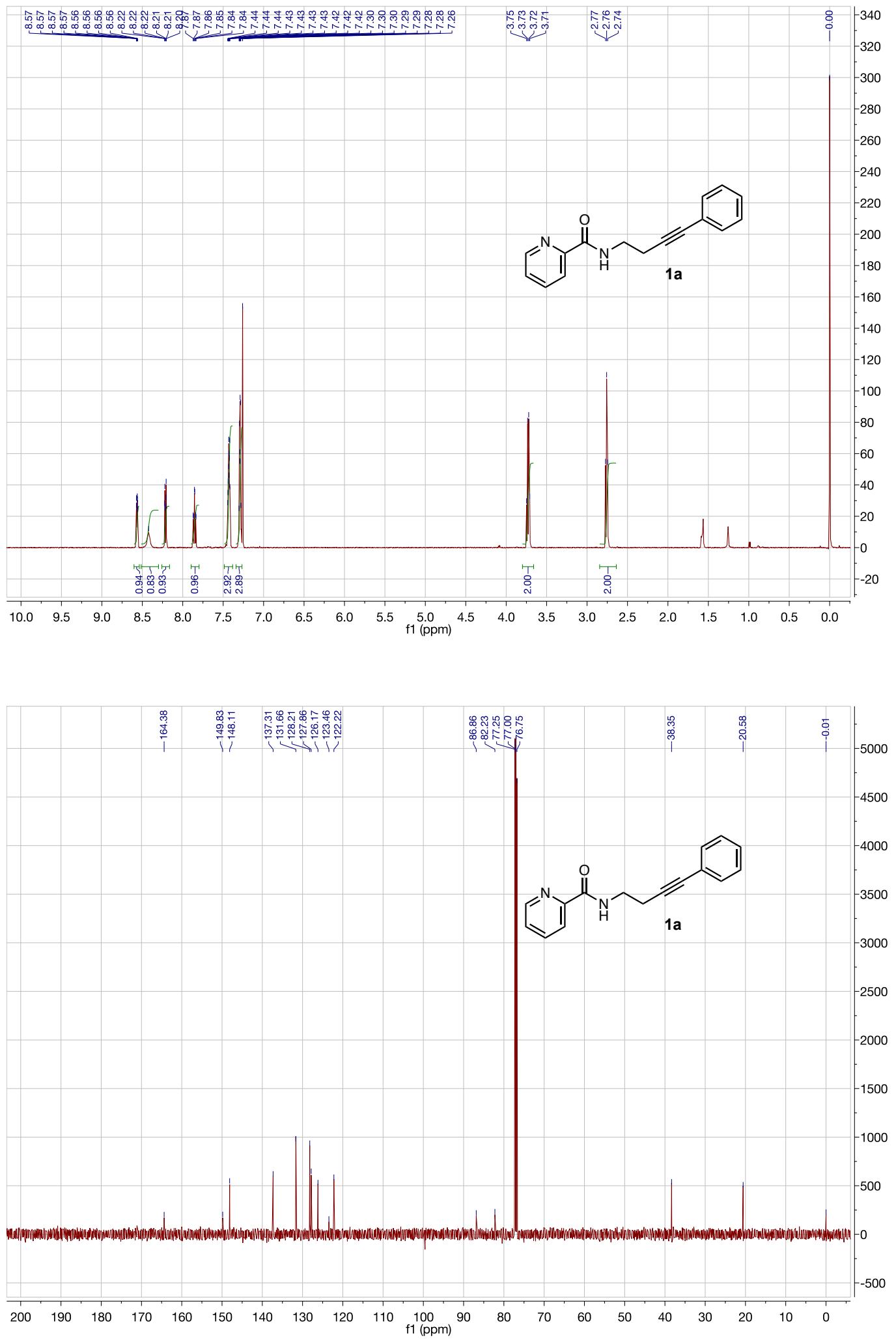

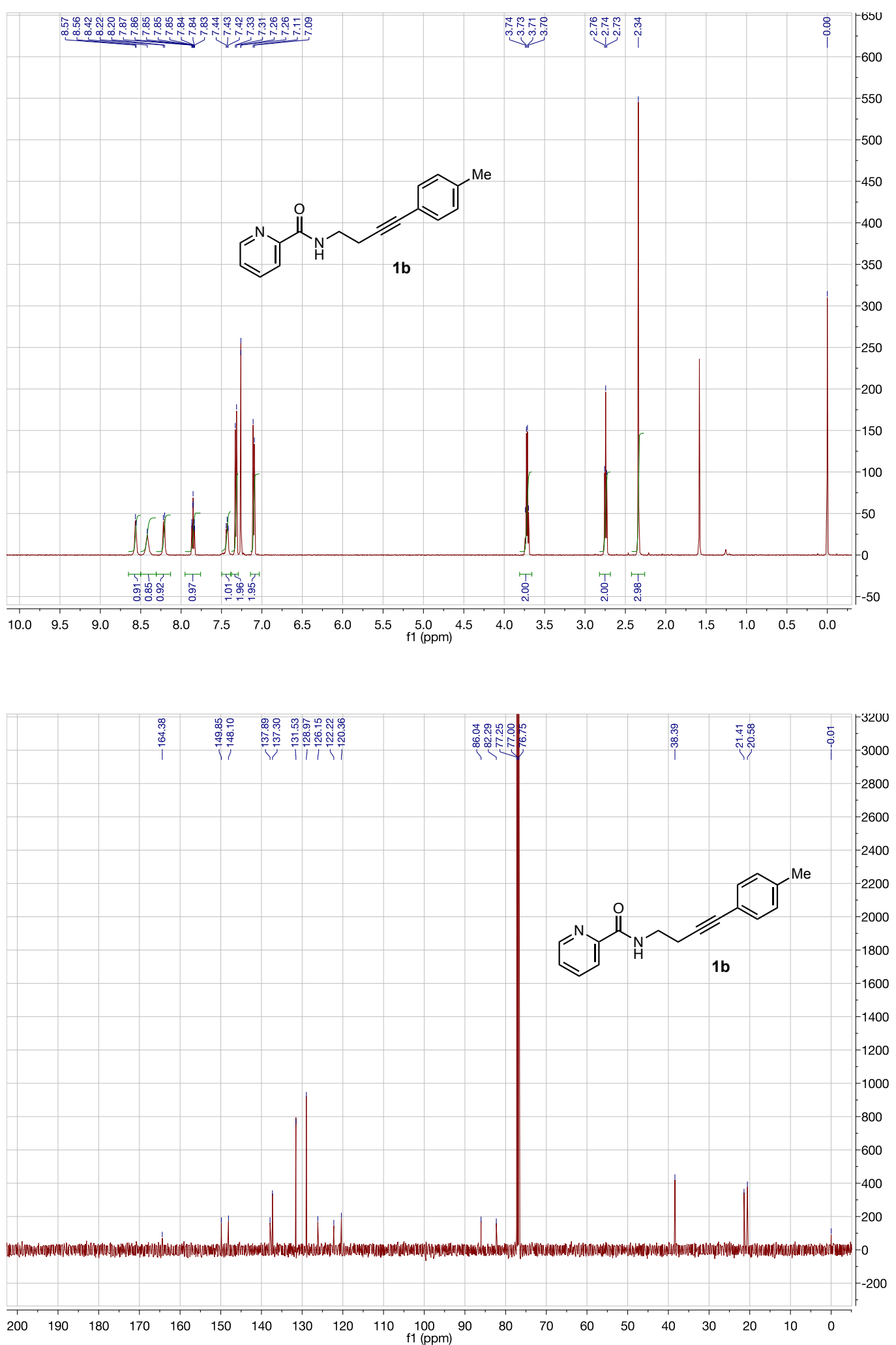

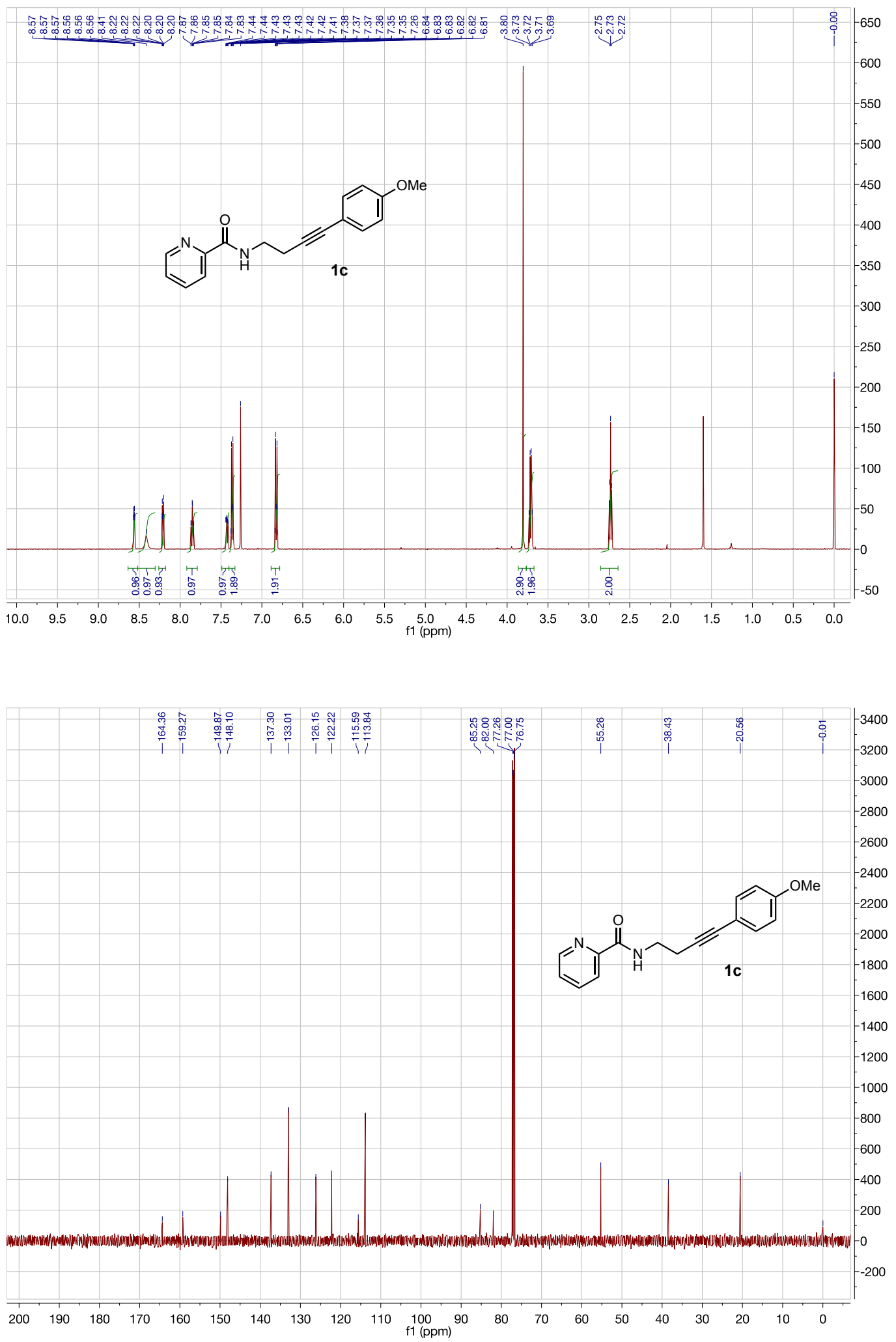

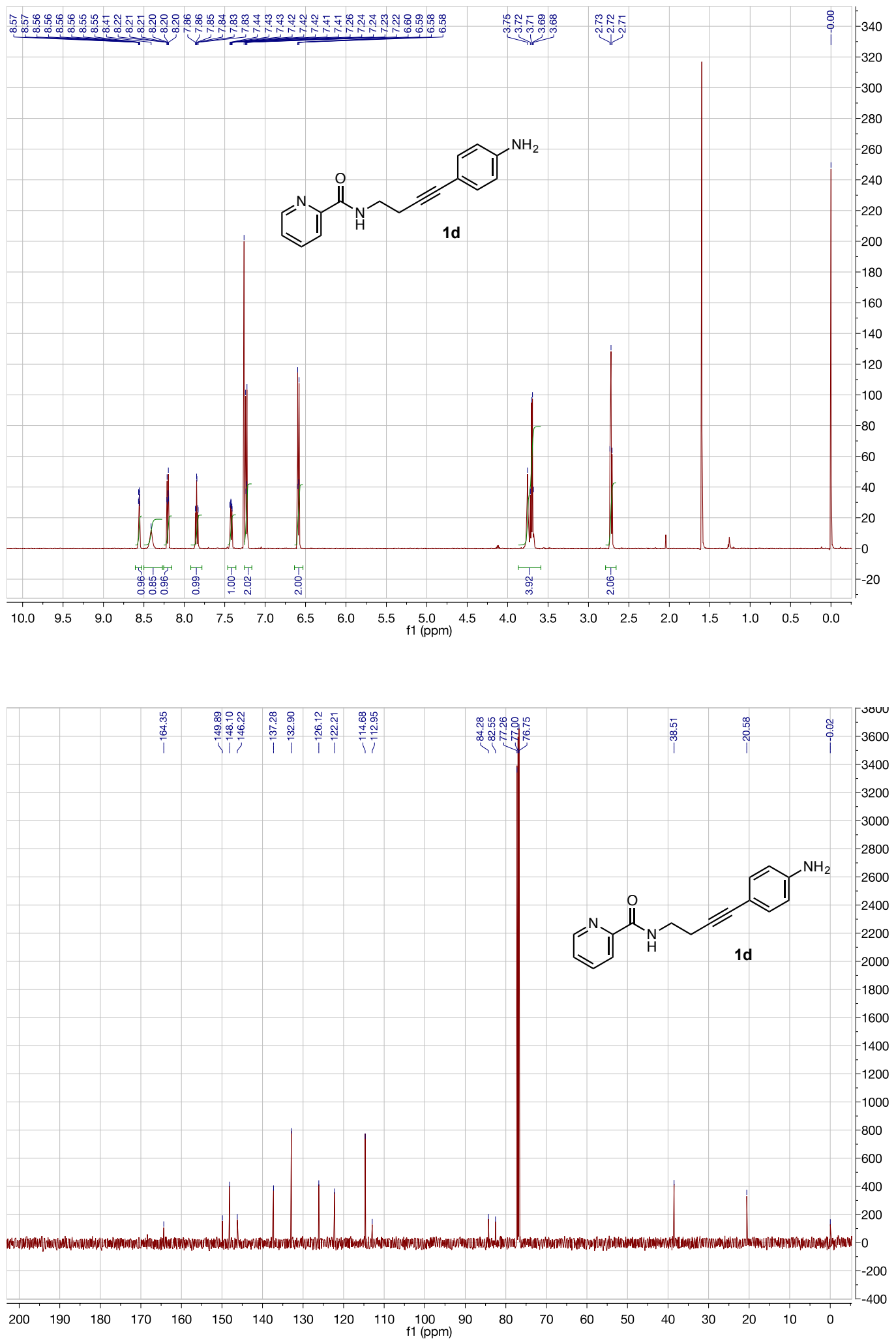

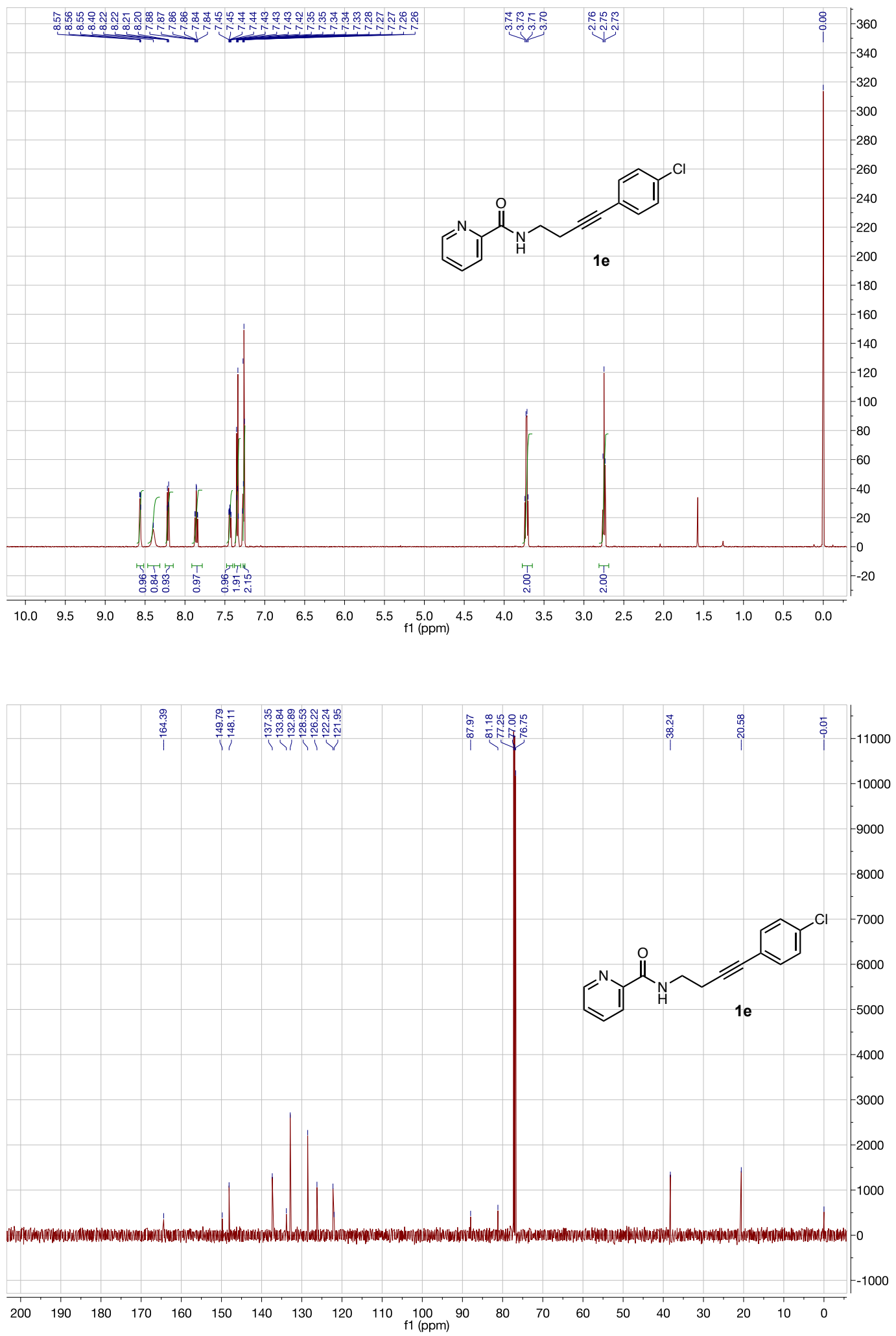

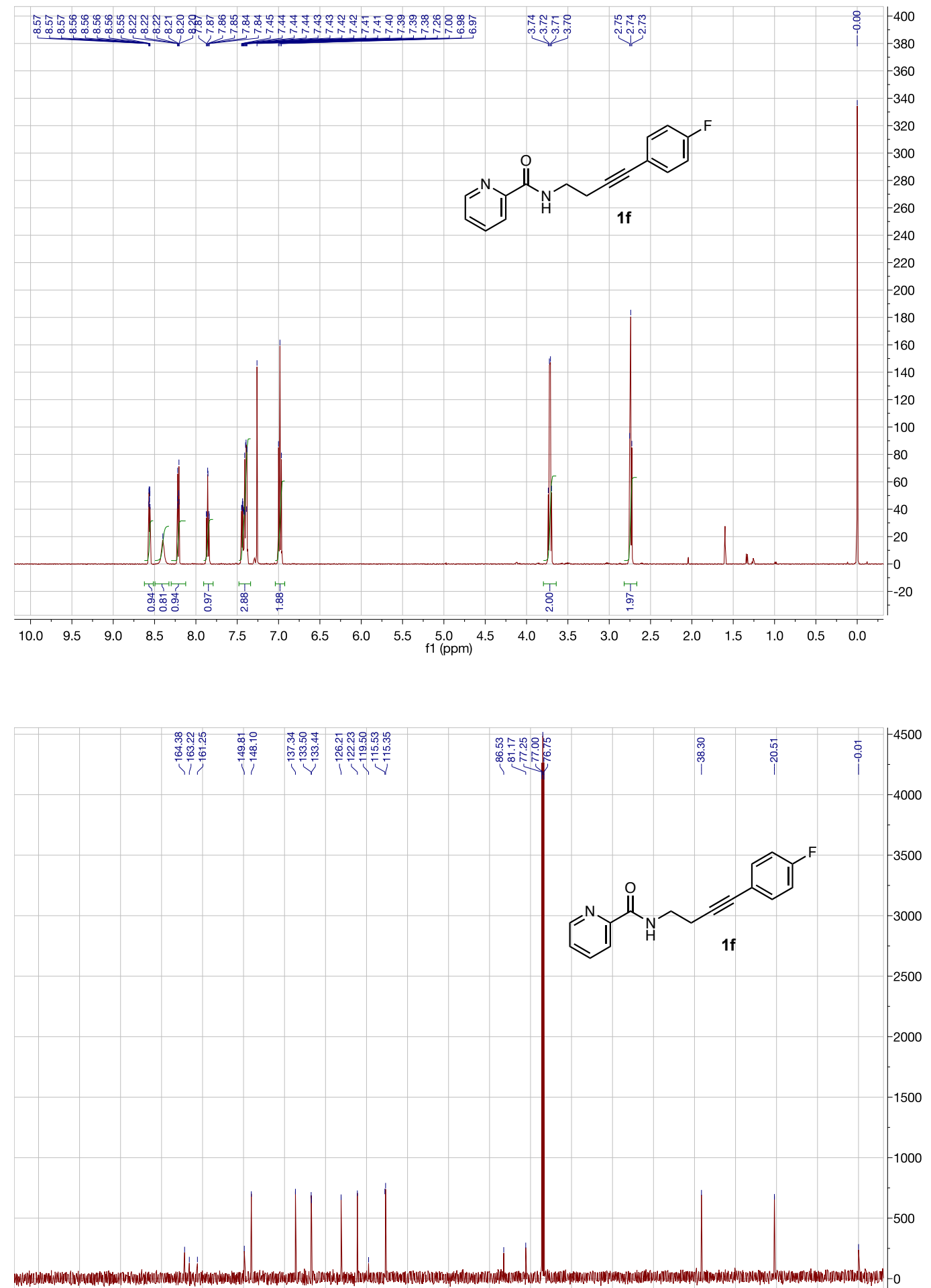

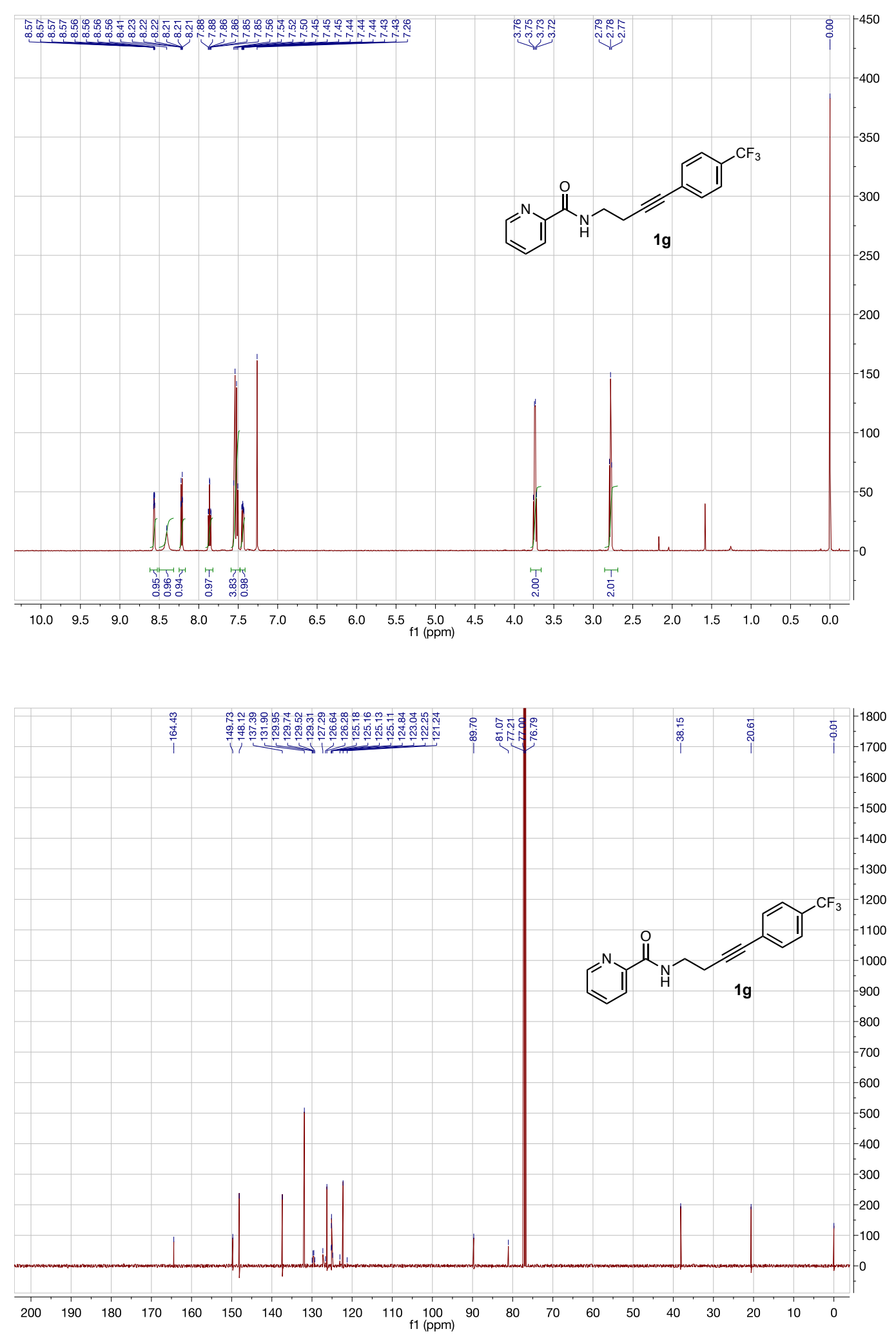

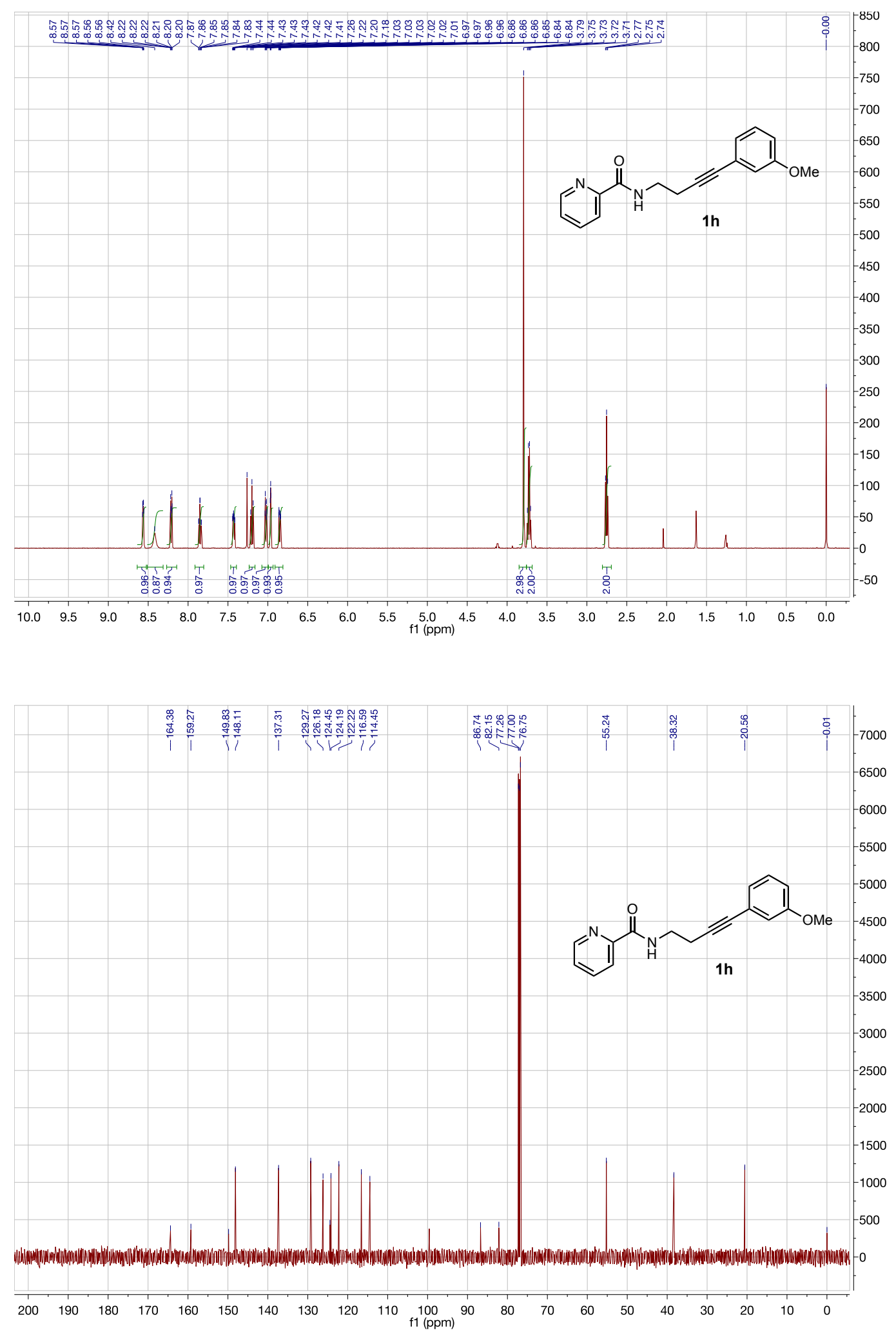

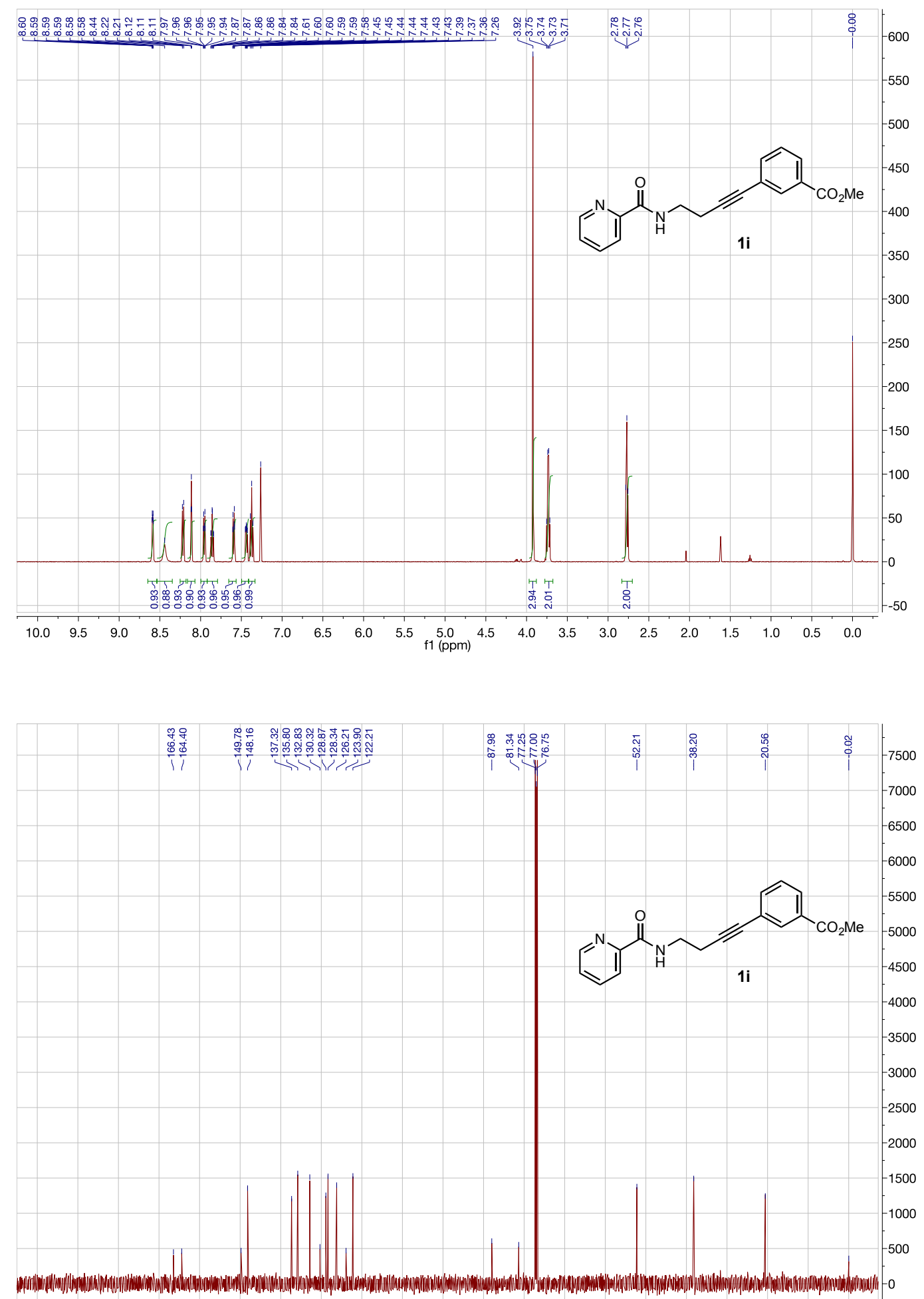

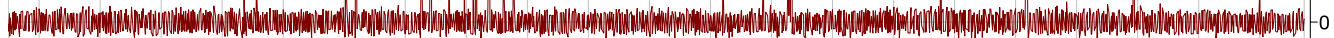

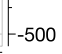

$\begin{array}{lllllllllllllllllllll}200 & 190 & 180 & 170 & 160 & 150 & 140 & 130 & 120 & 110 & \begin{array}{c}100 \\ 1\end{array}(\mathrm{ppm}) & 90 & 80 & 70 & 60 & 50 & 40 & 30 & 20 & 10 & 0\end{array}$ 

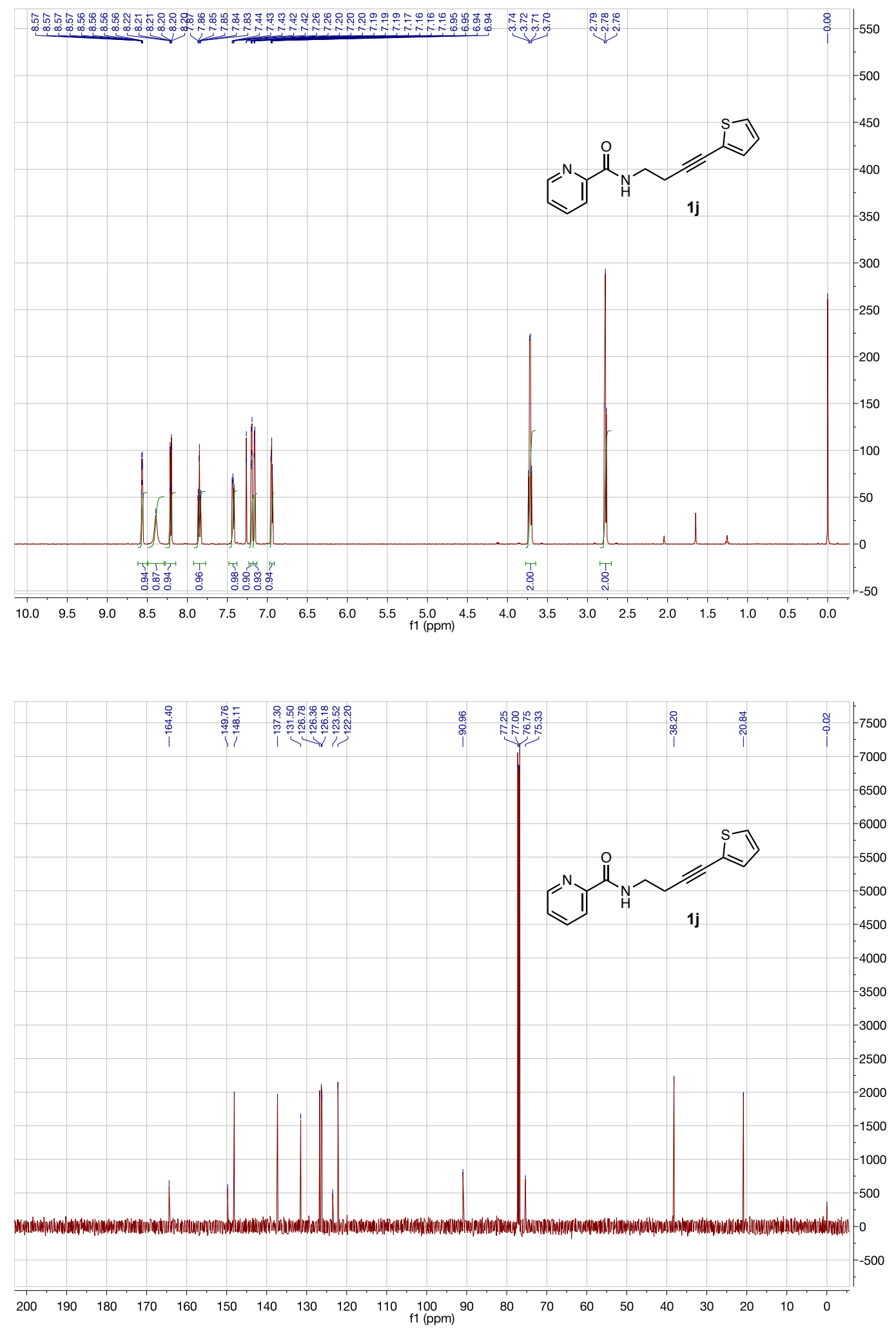

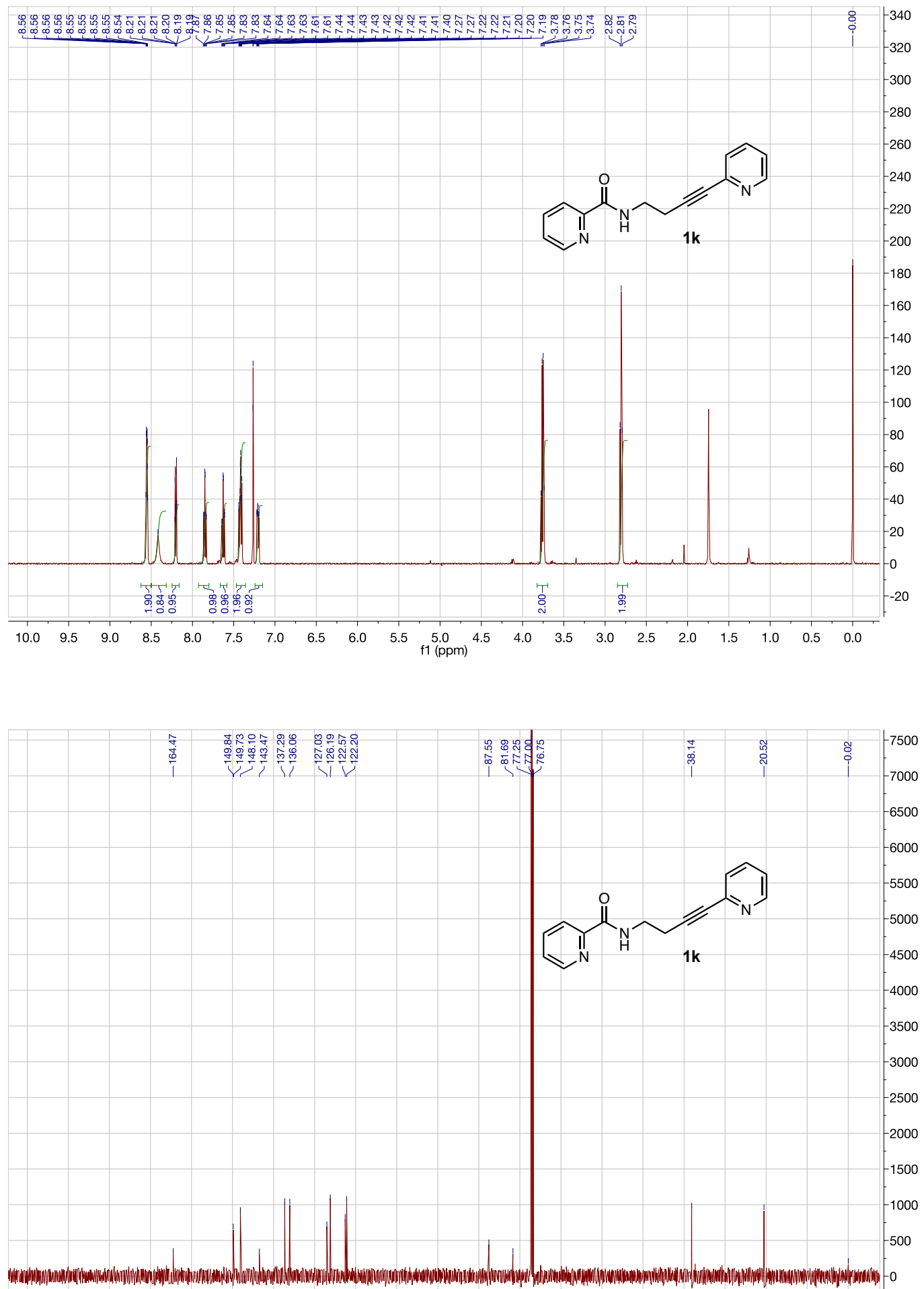

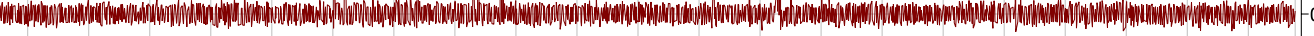



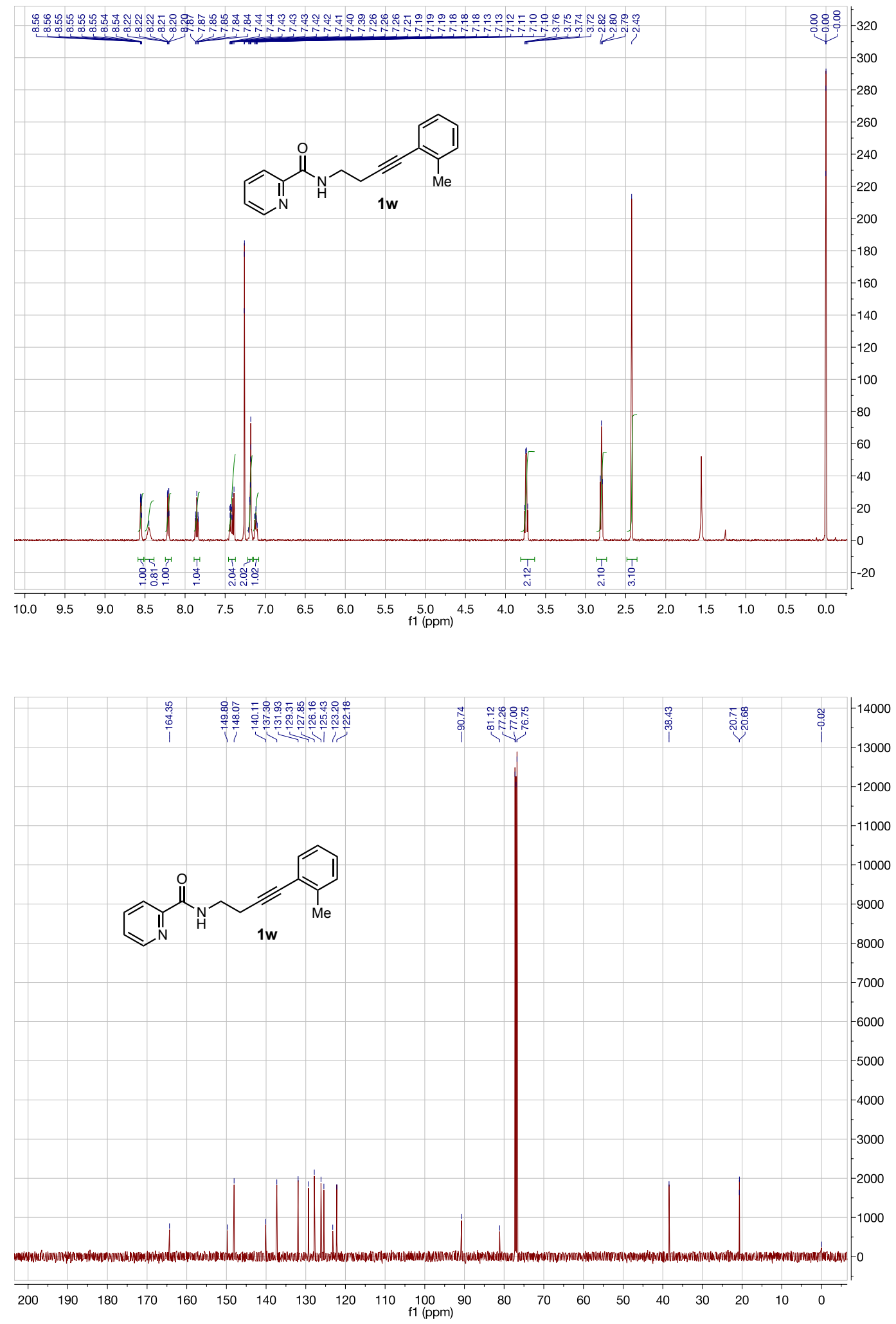


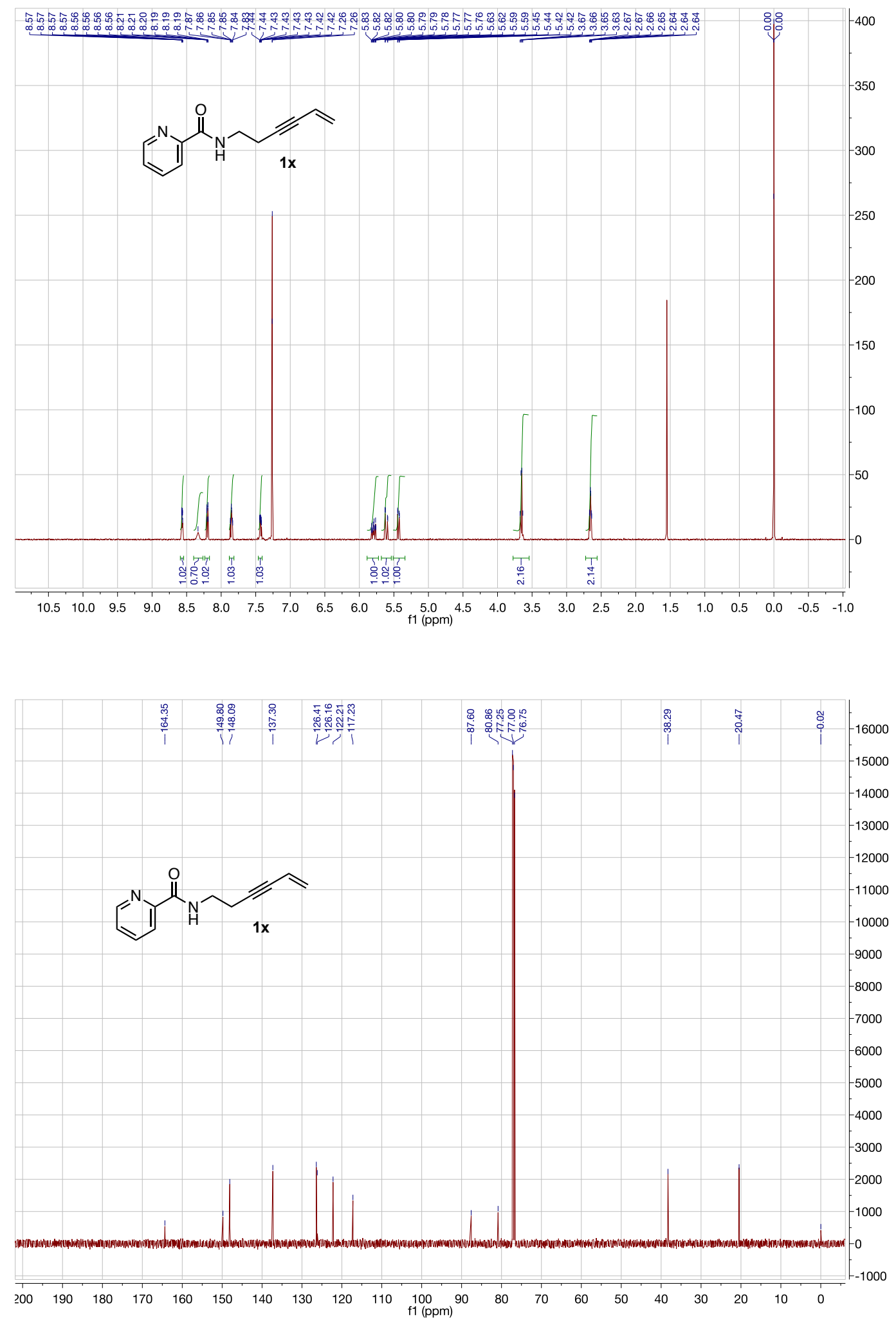

S-81 

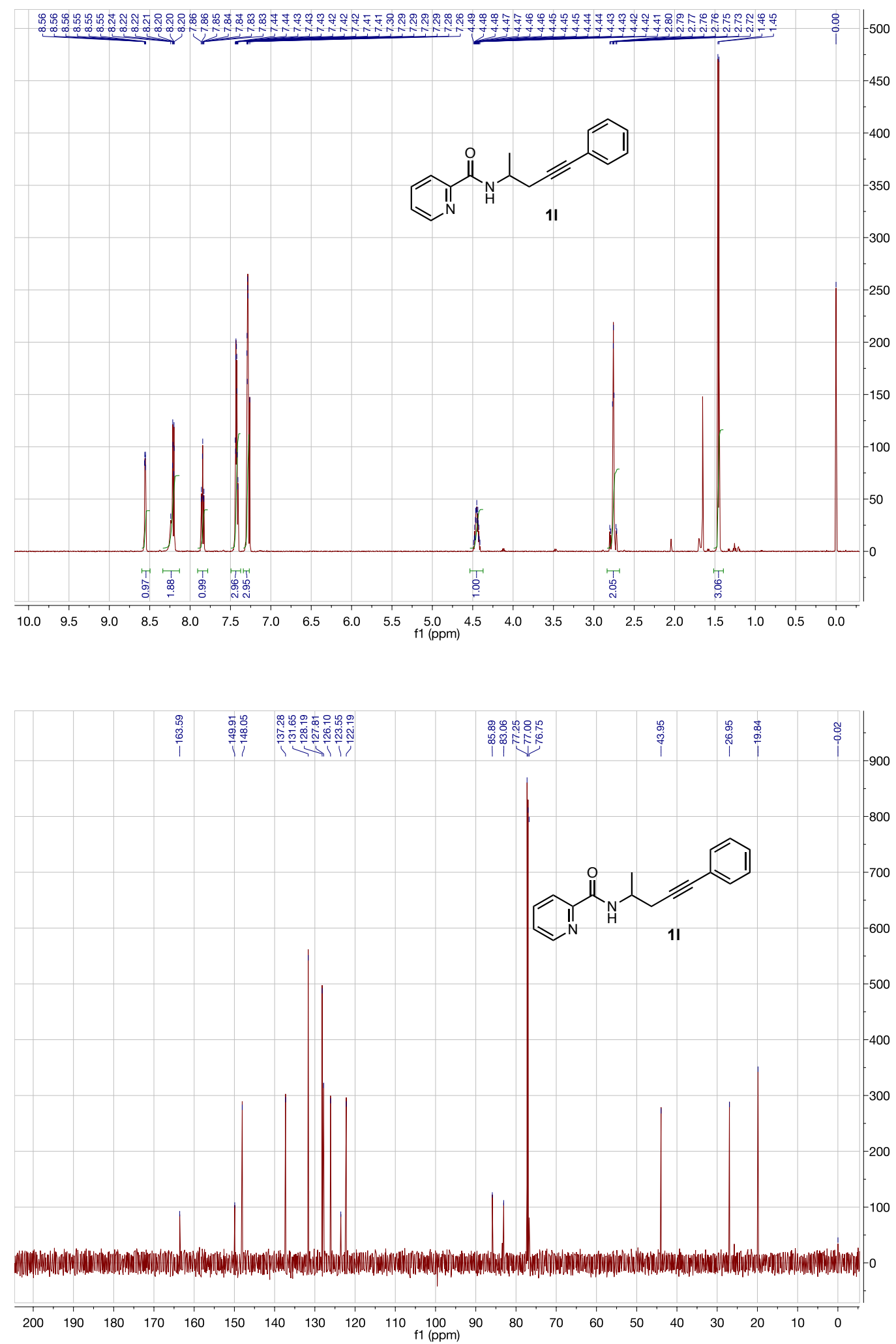

S-82 

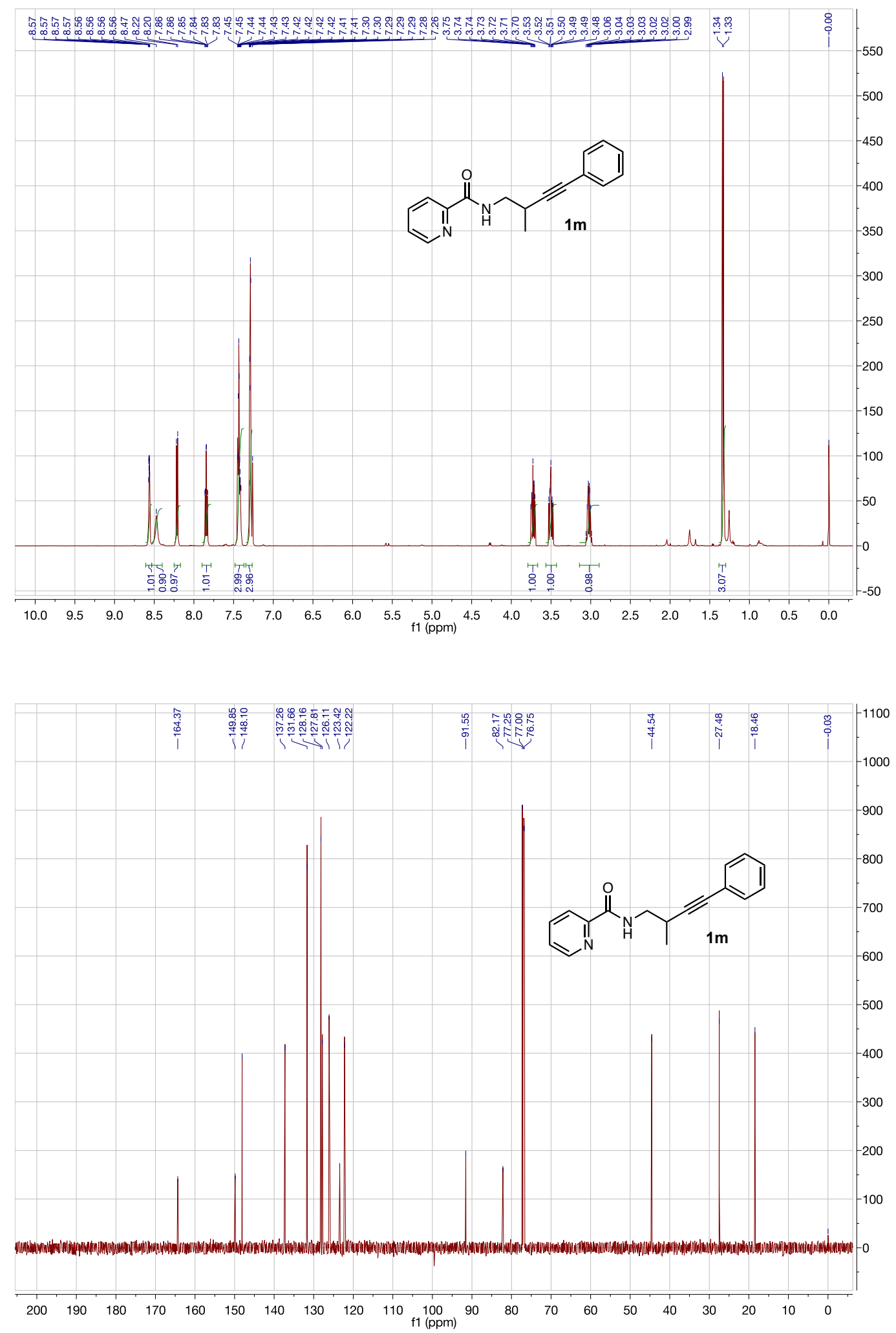

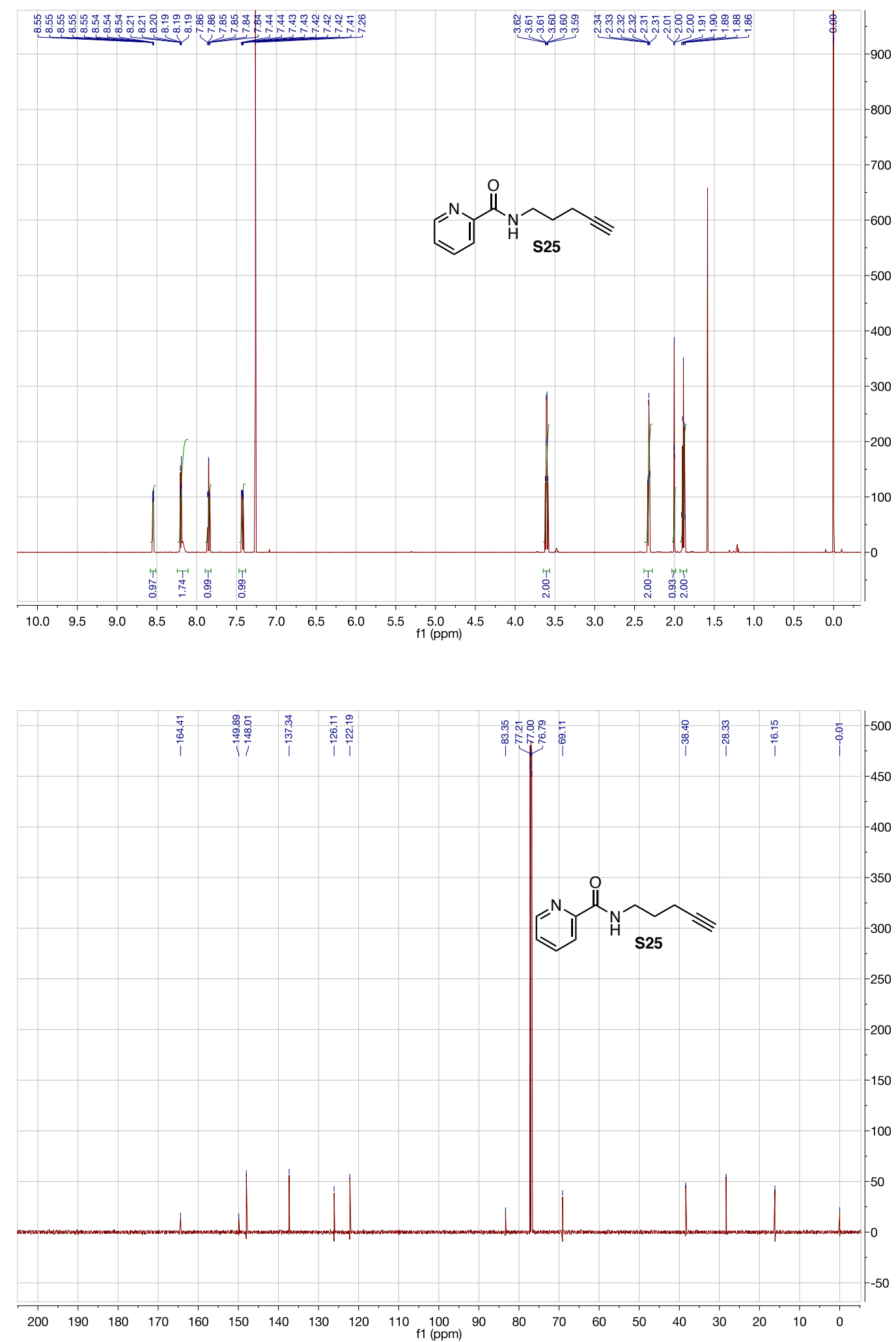

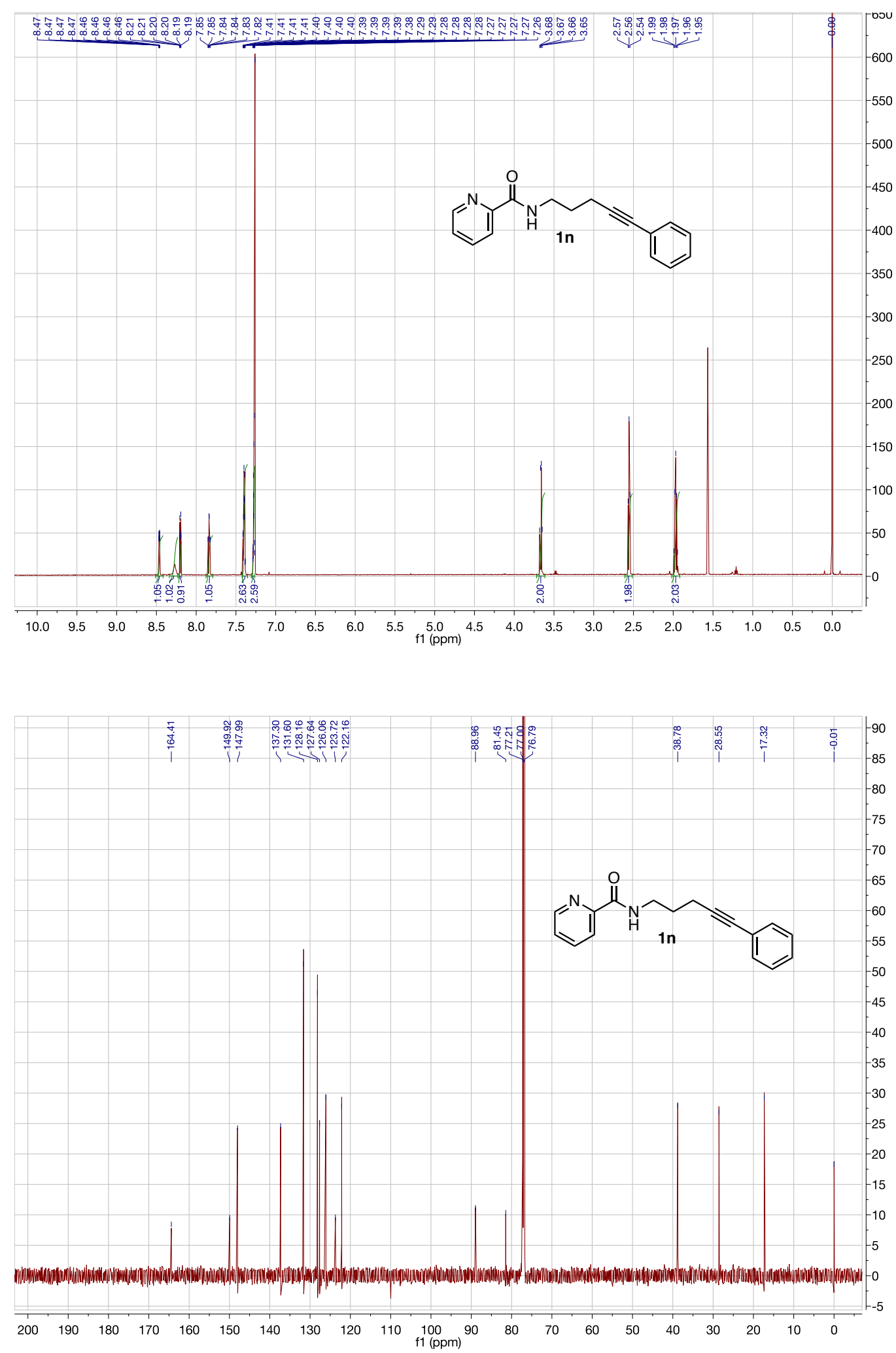

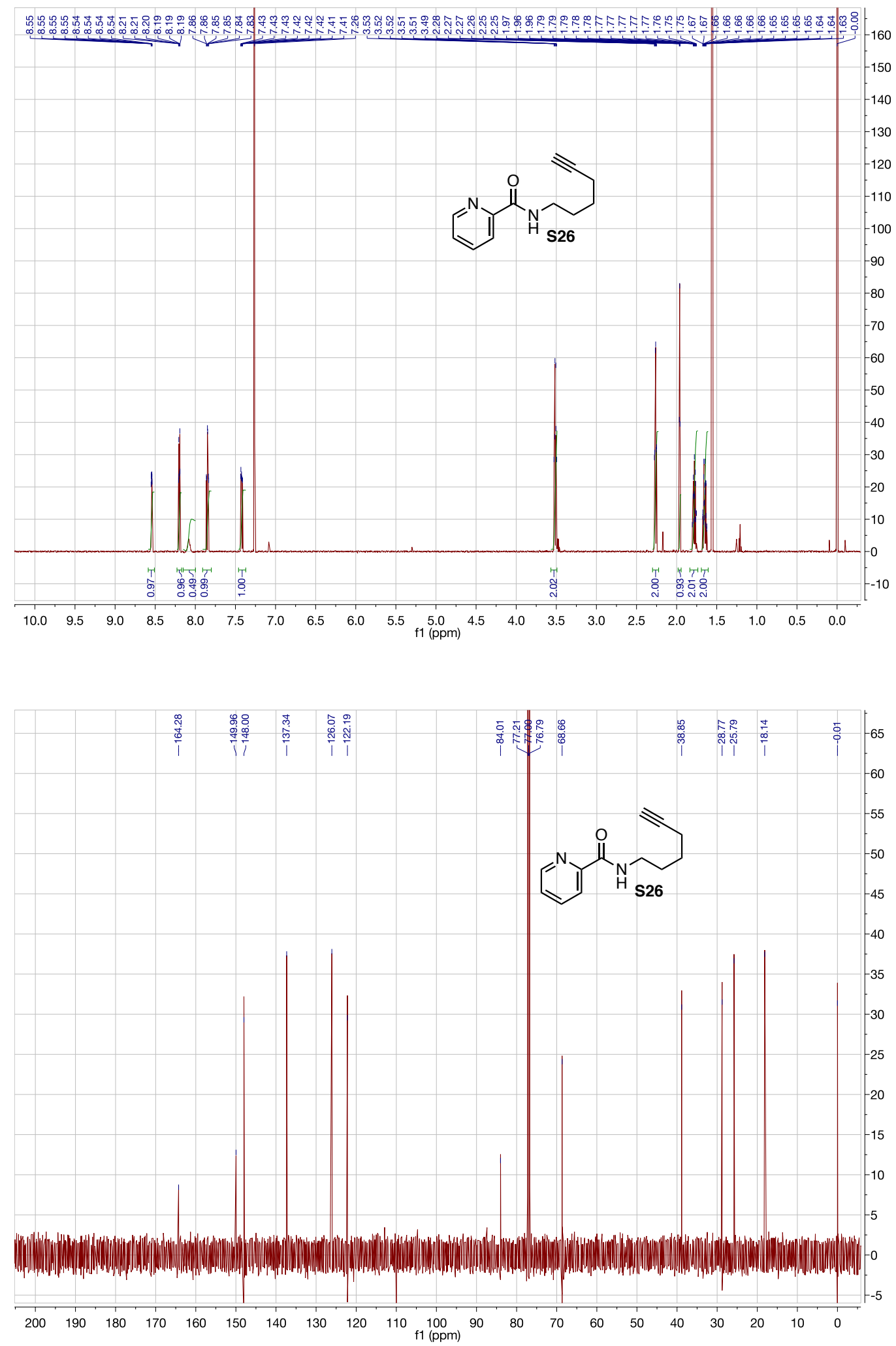

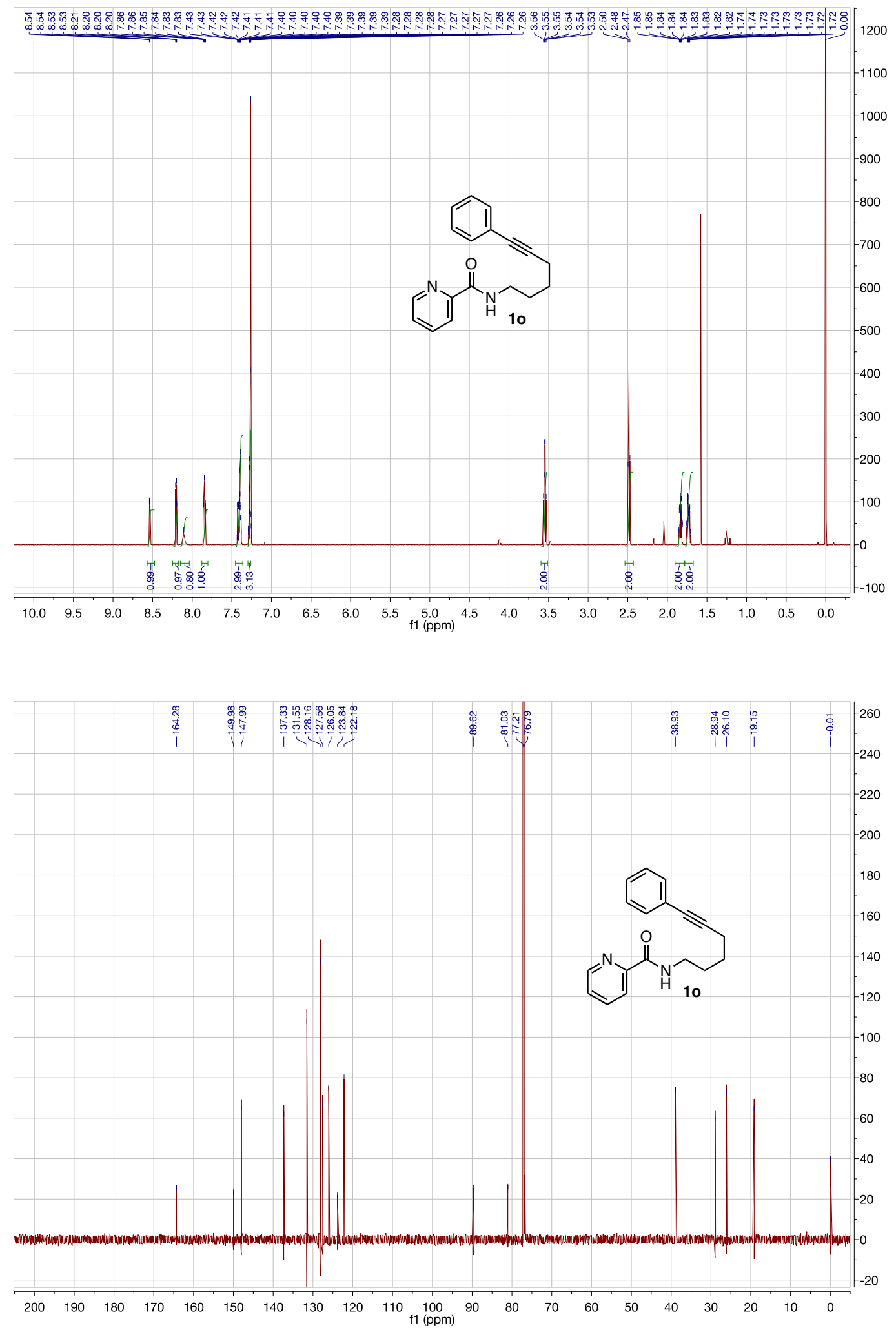

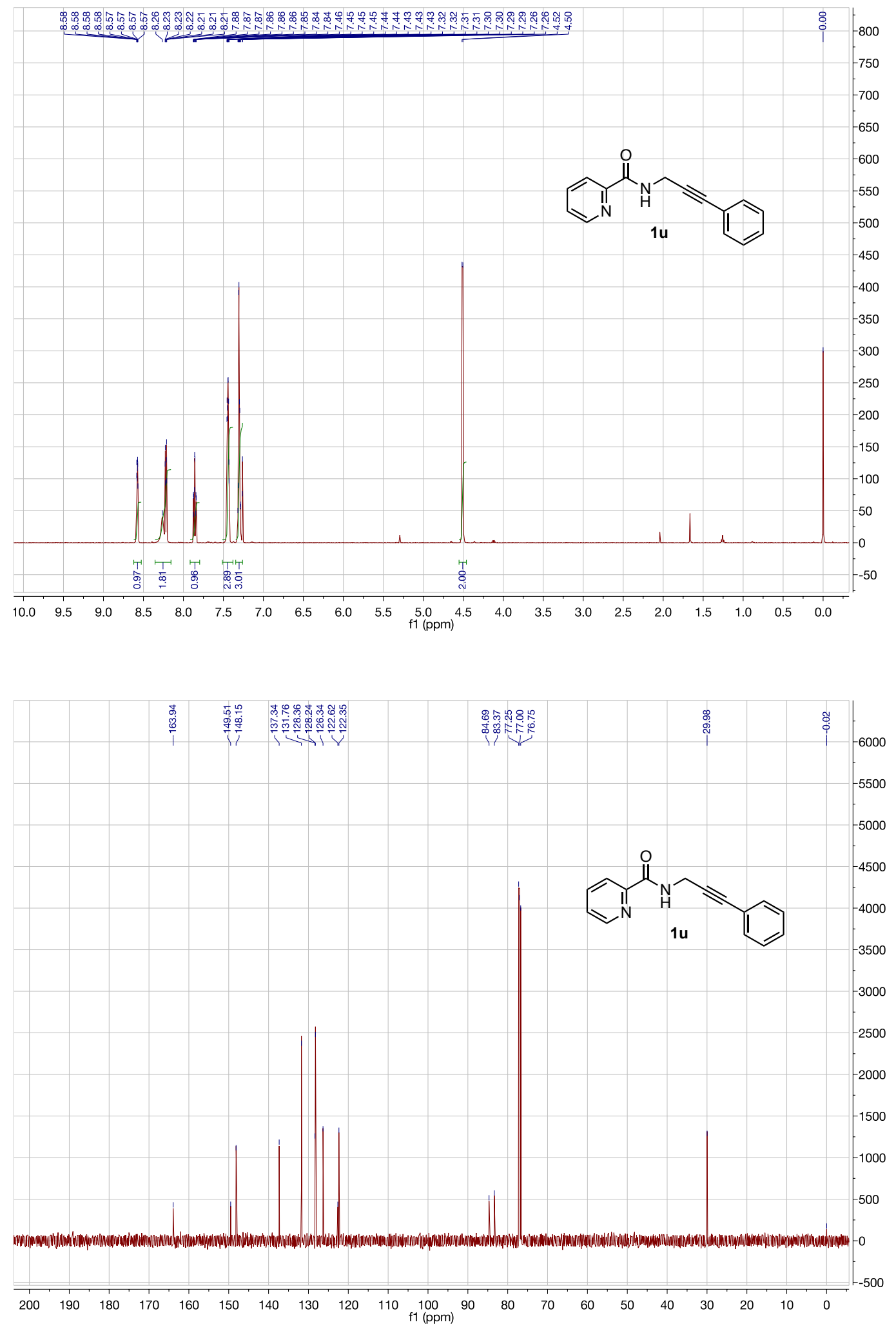

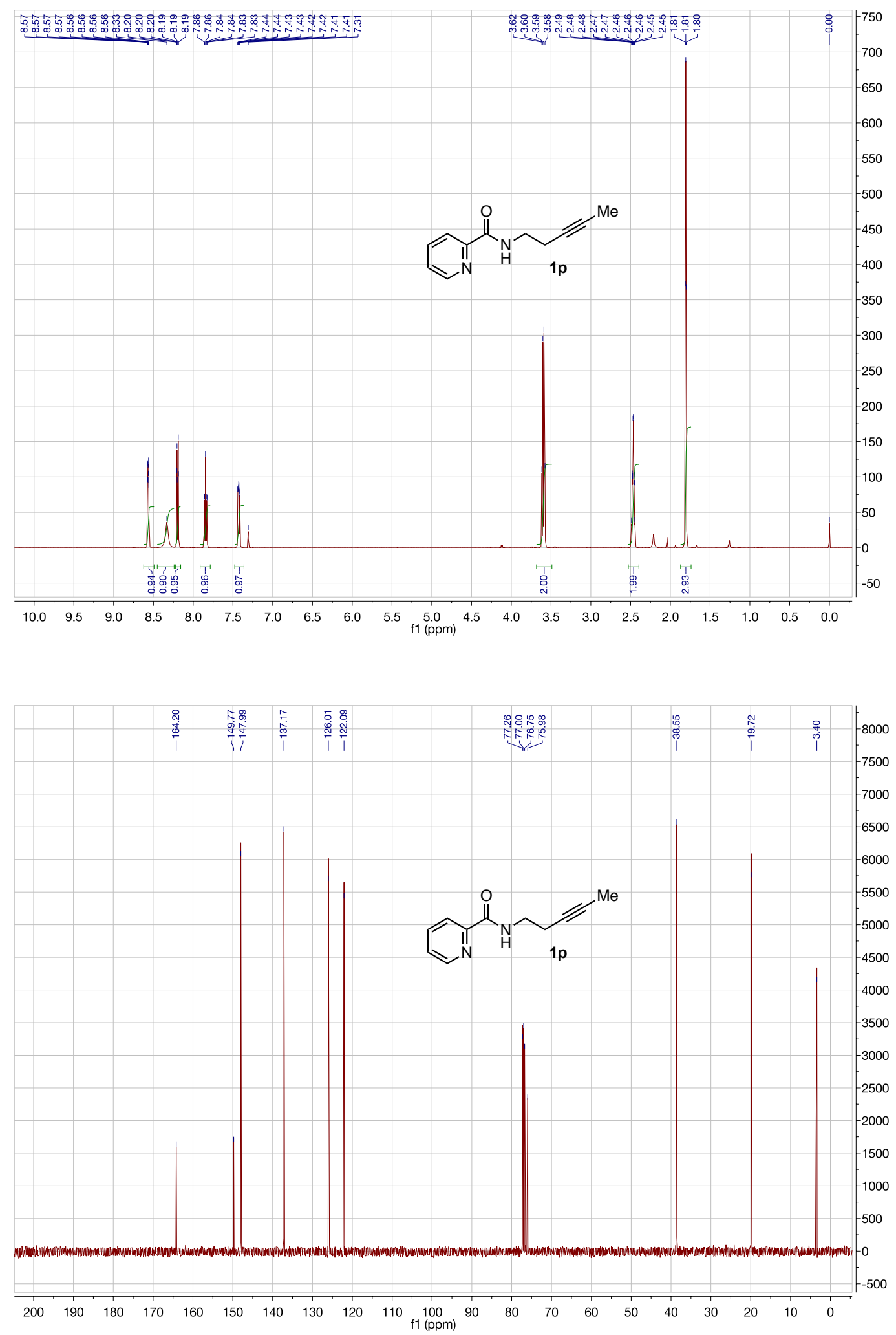

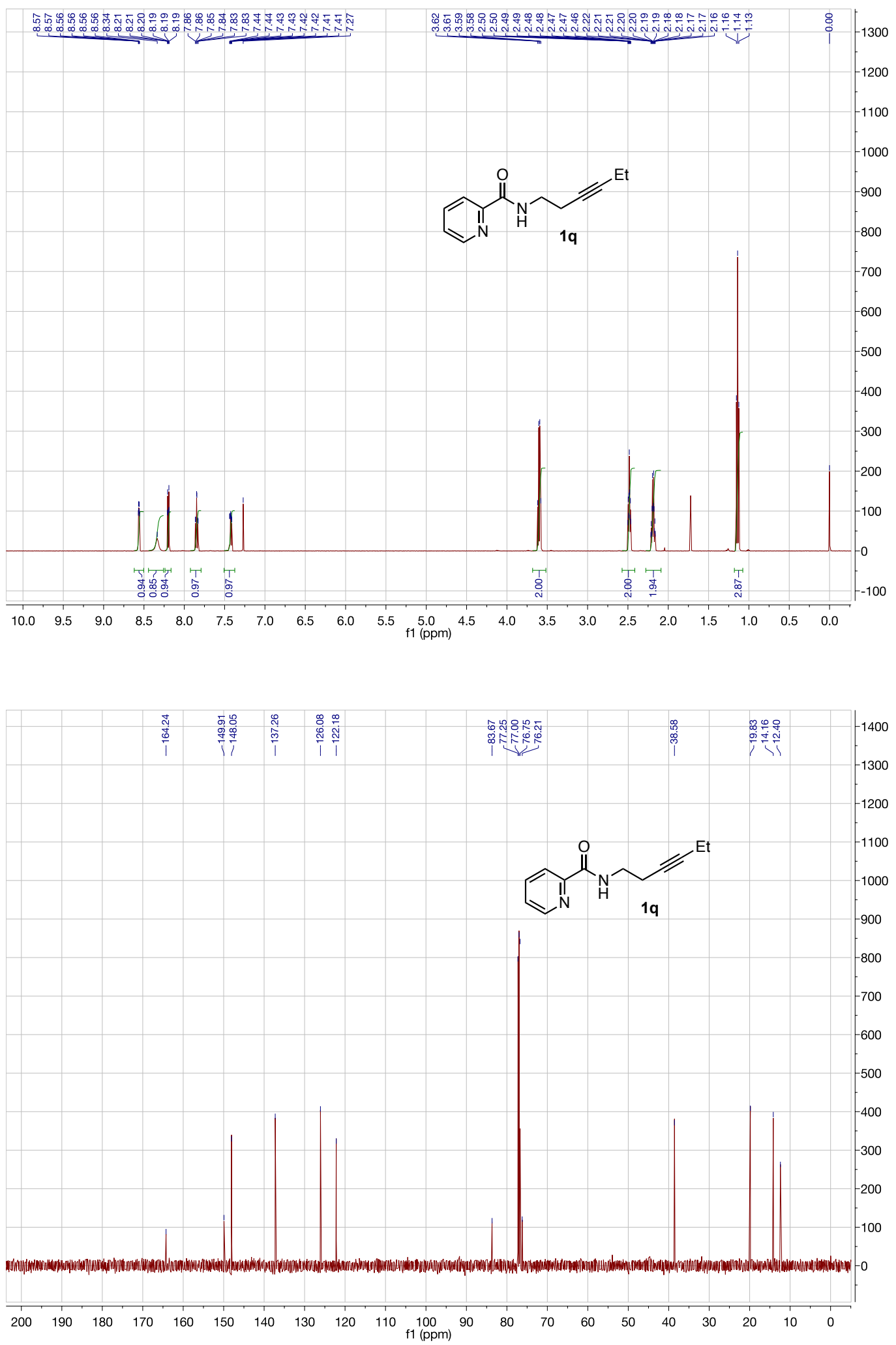

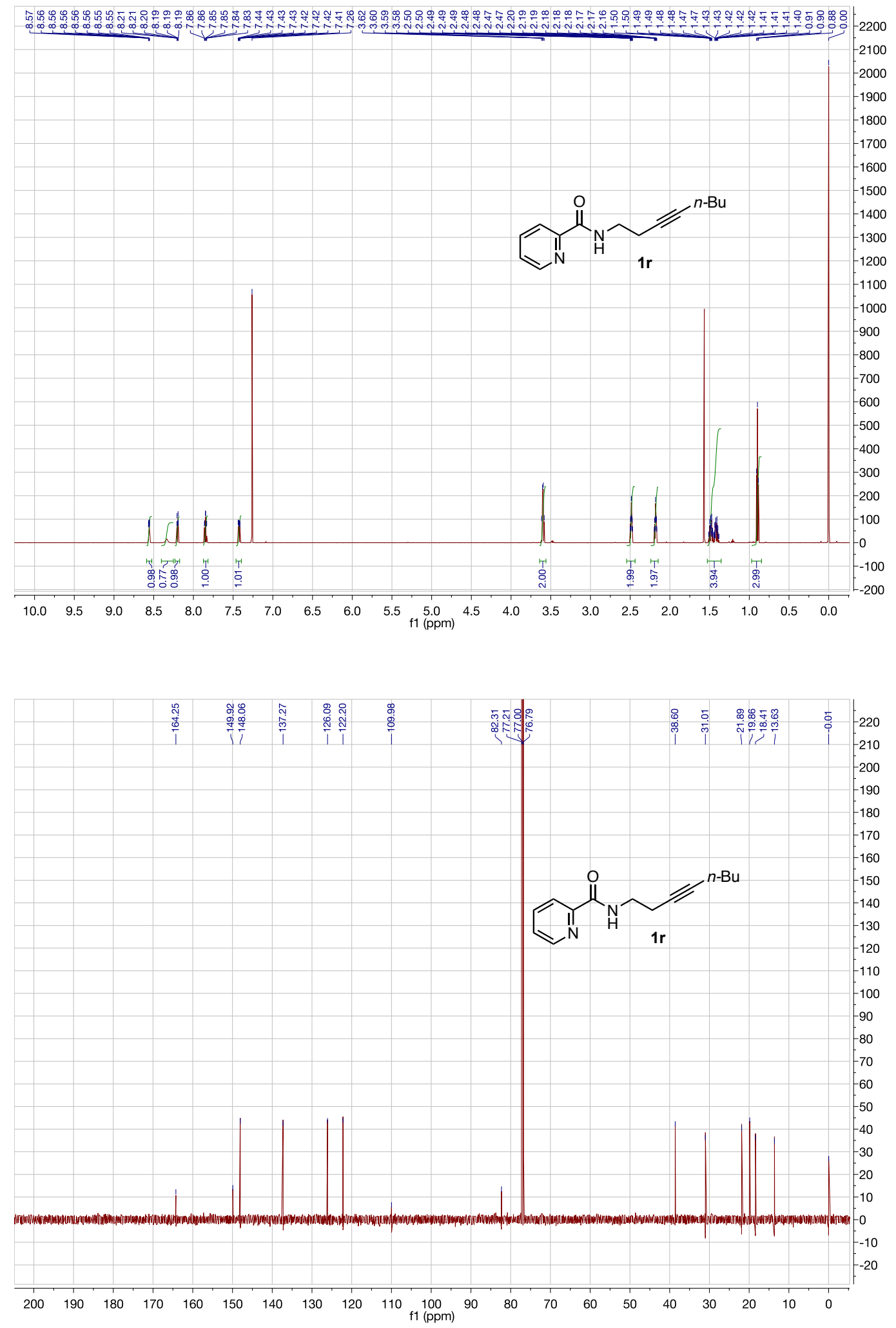

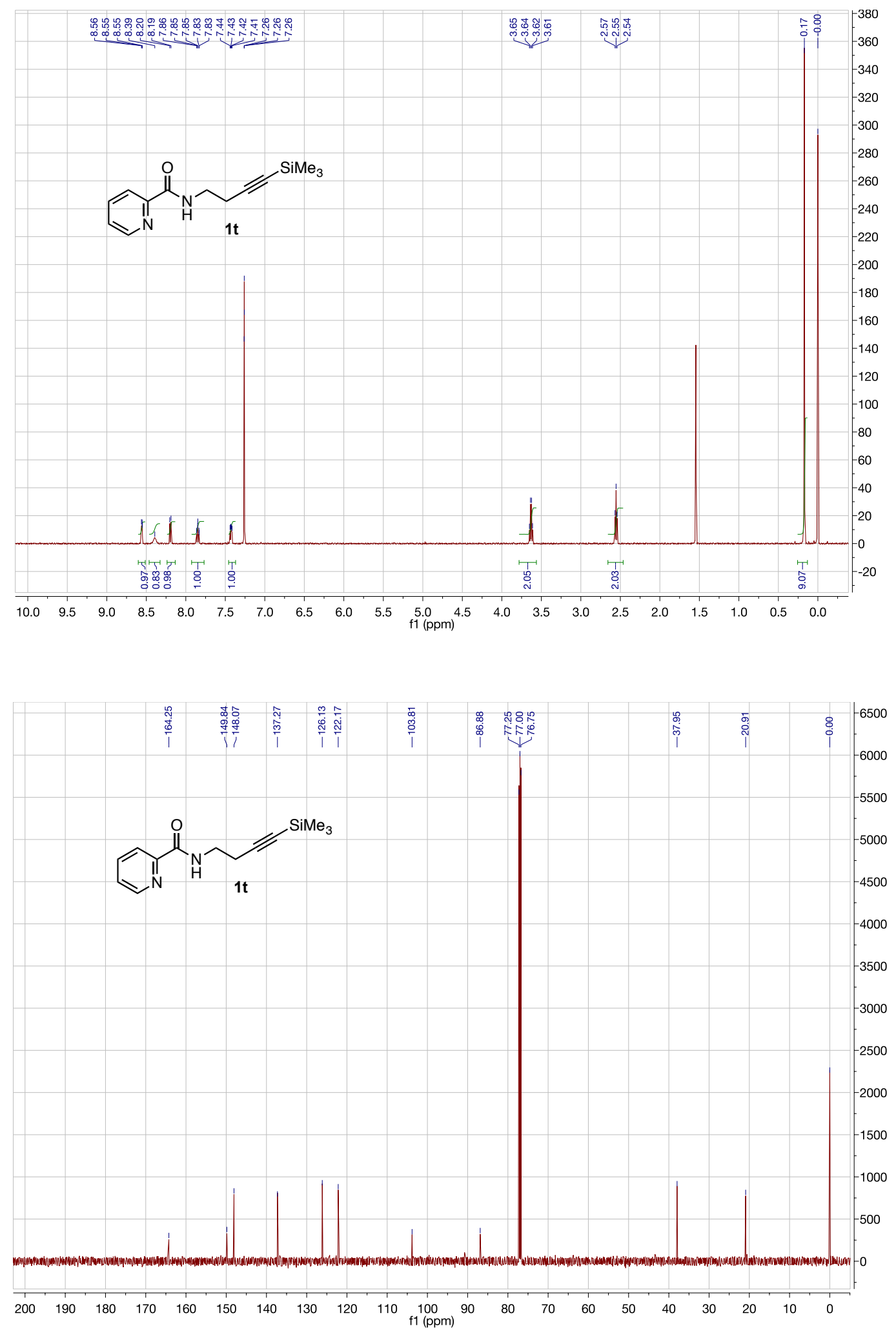

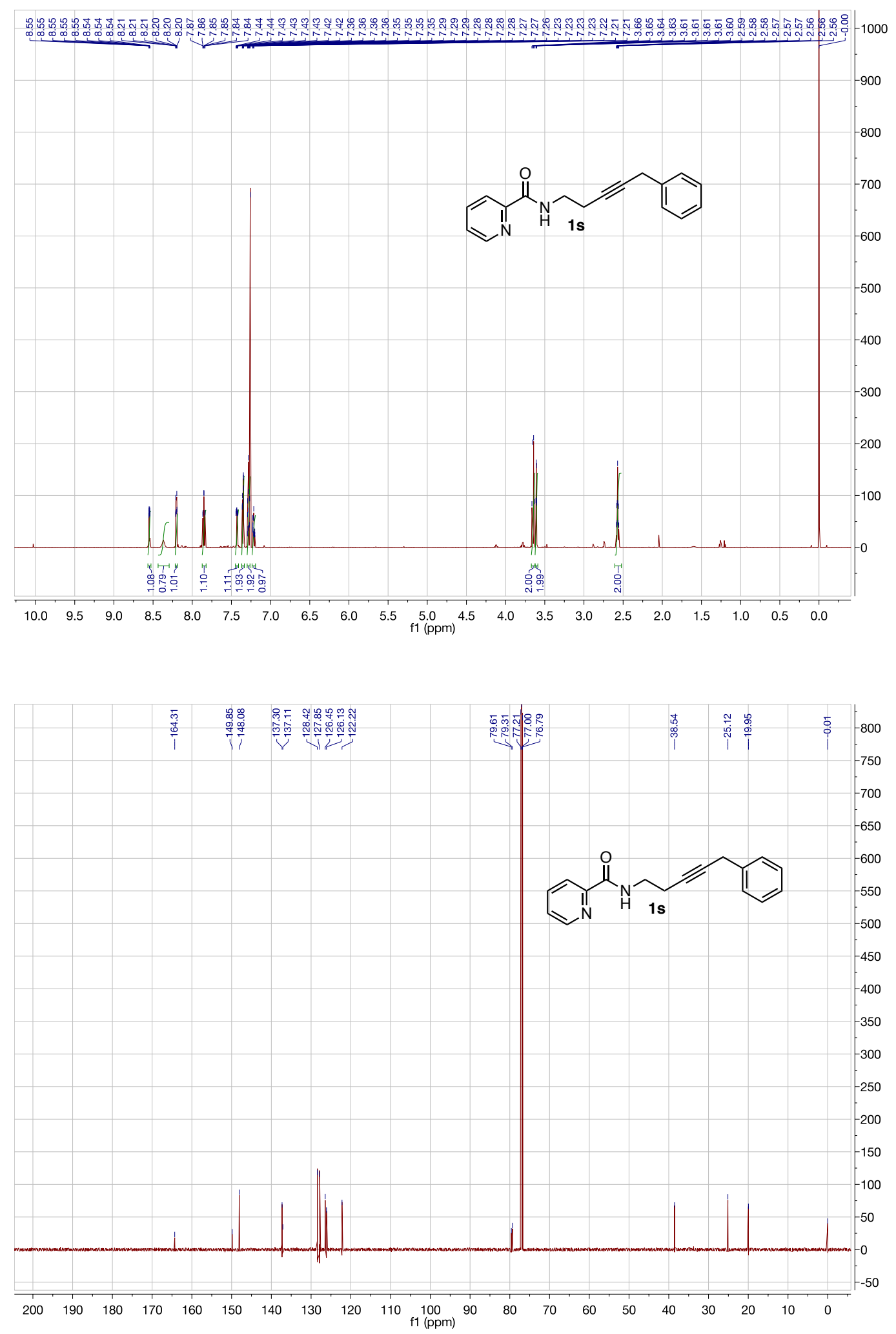

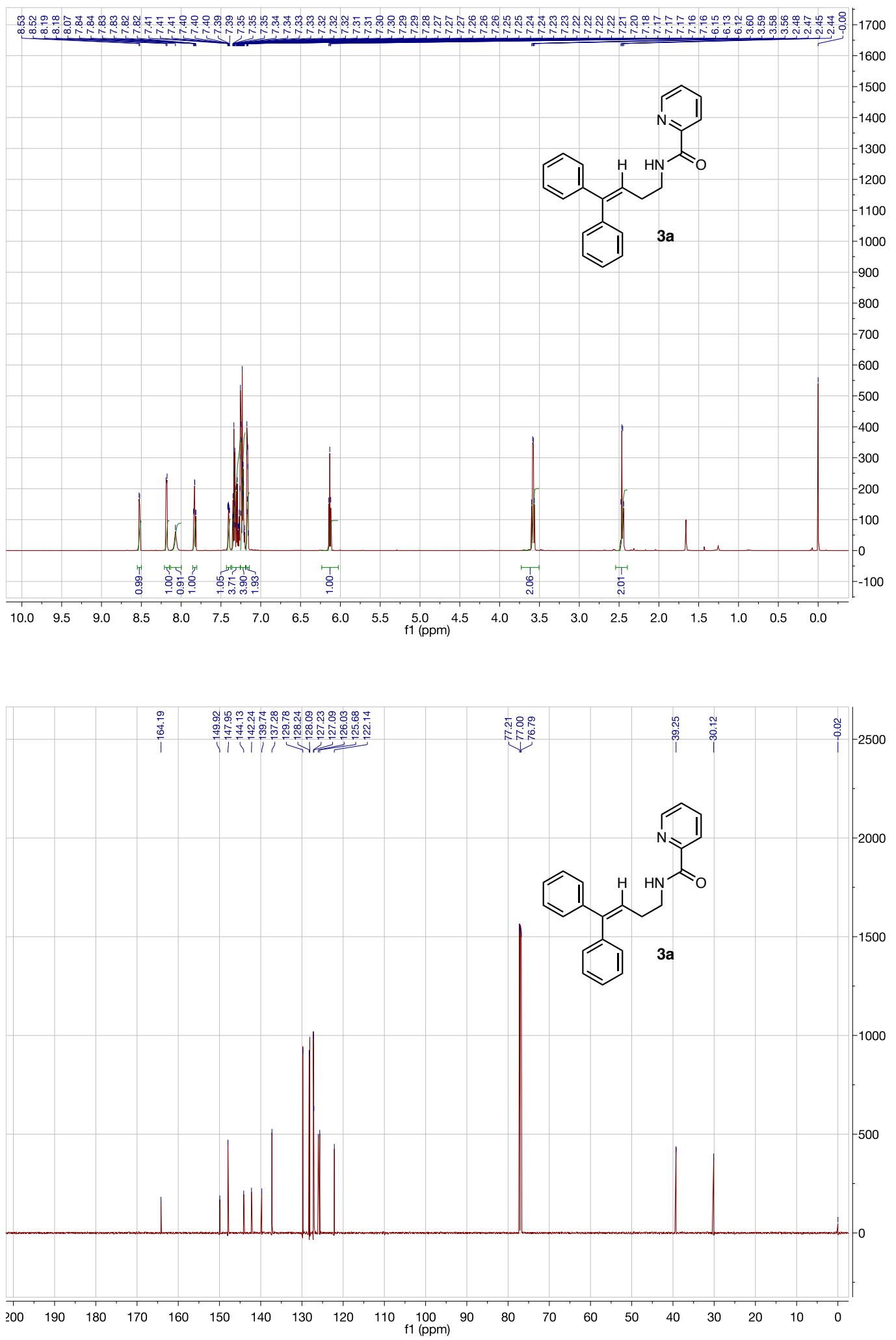

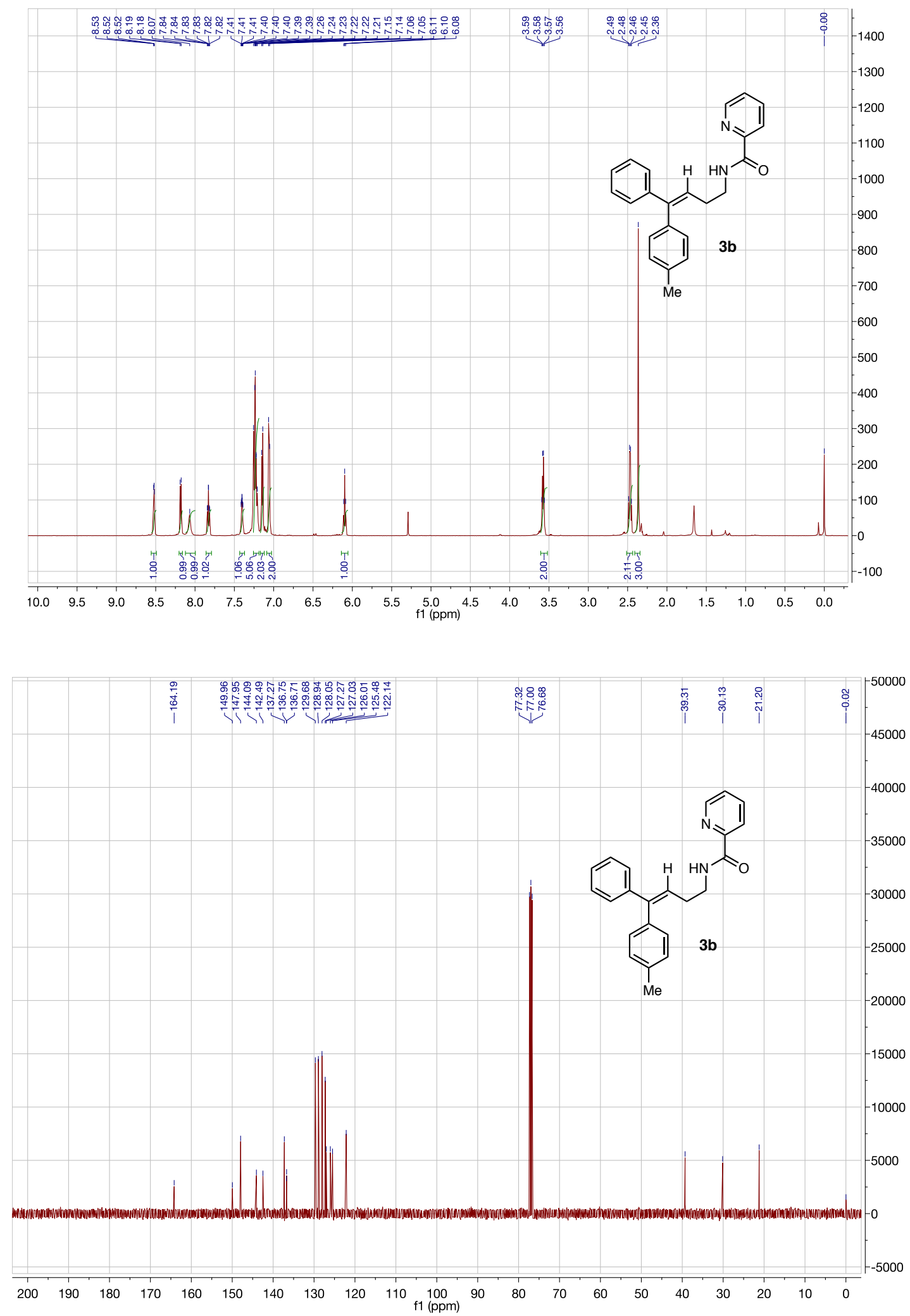

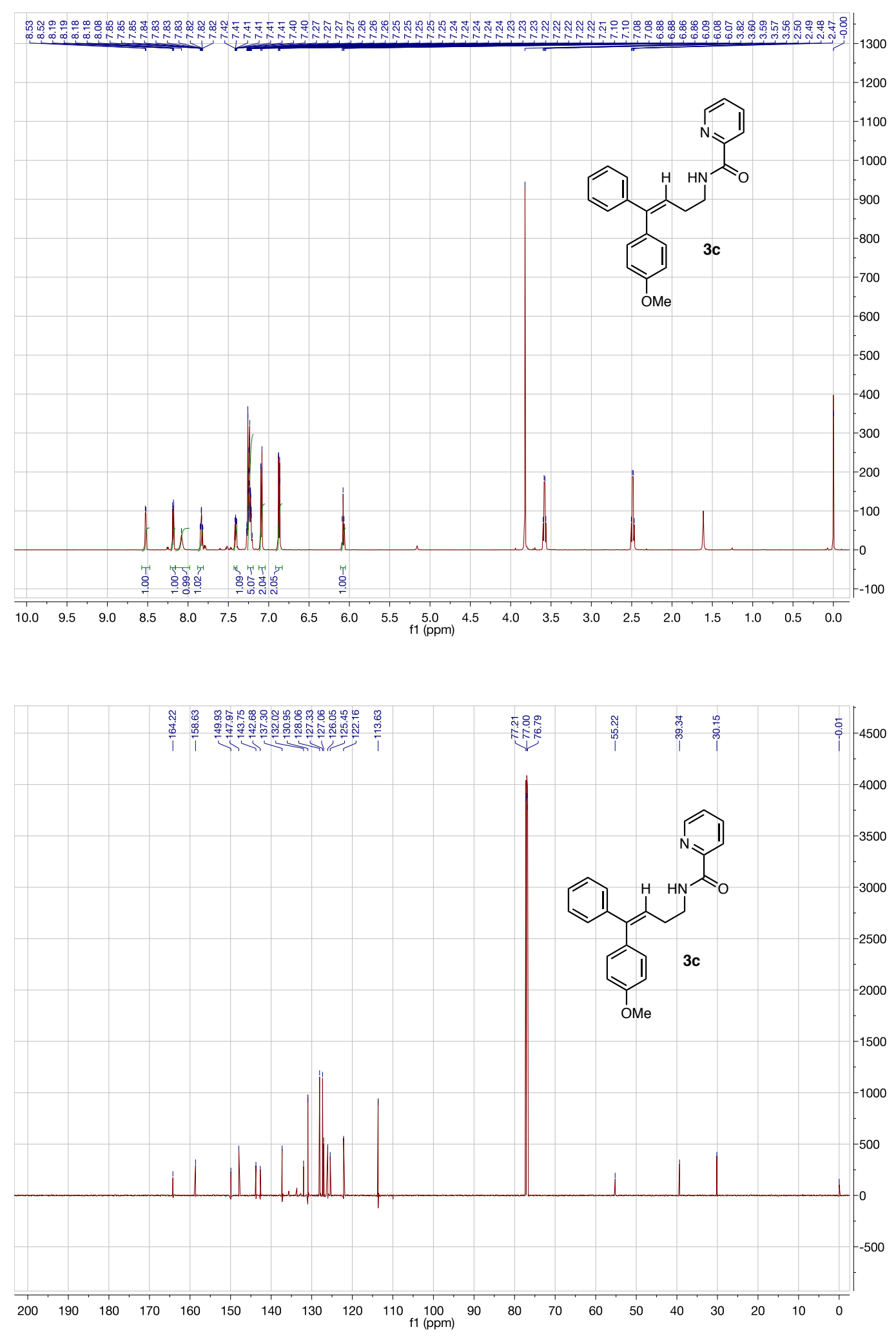

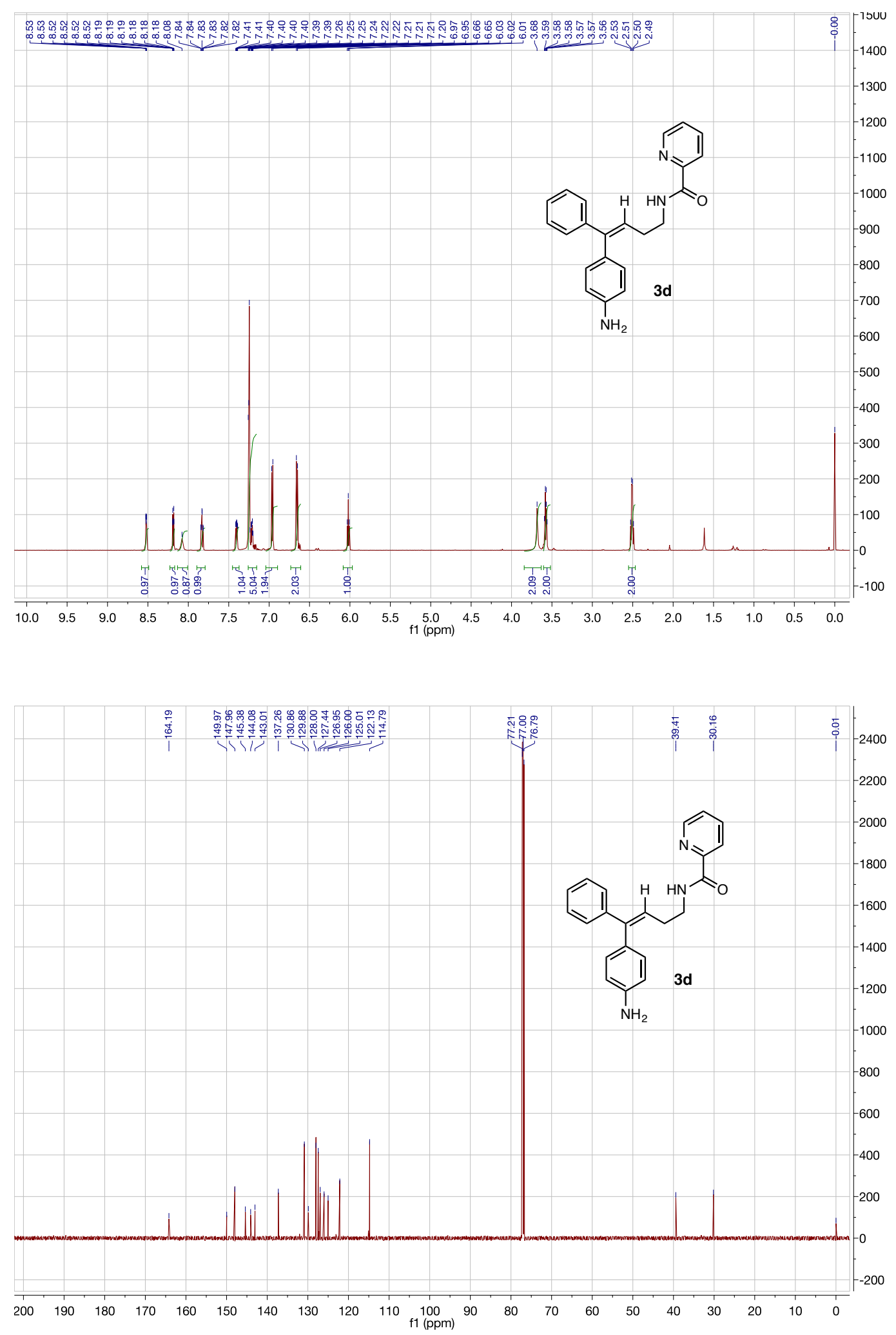

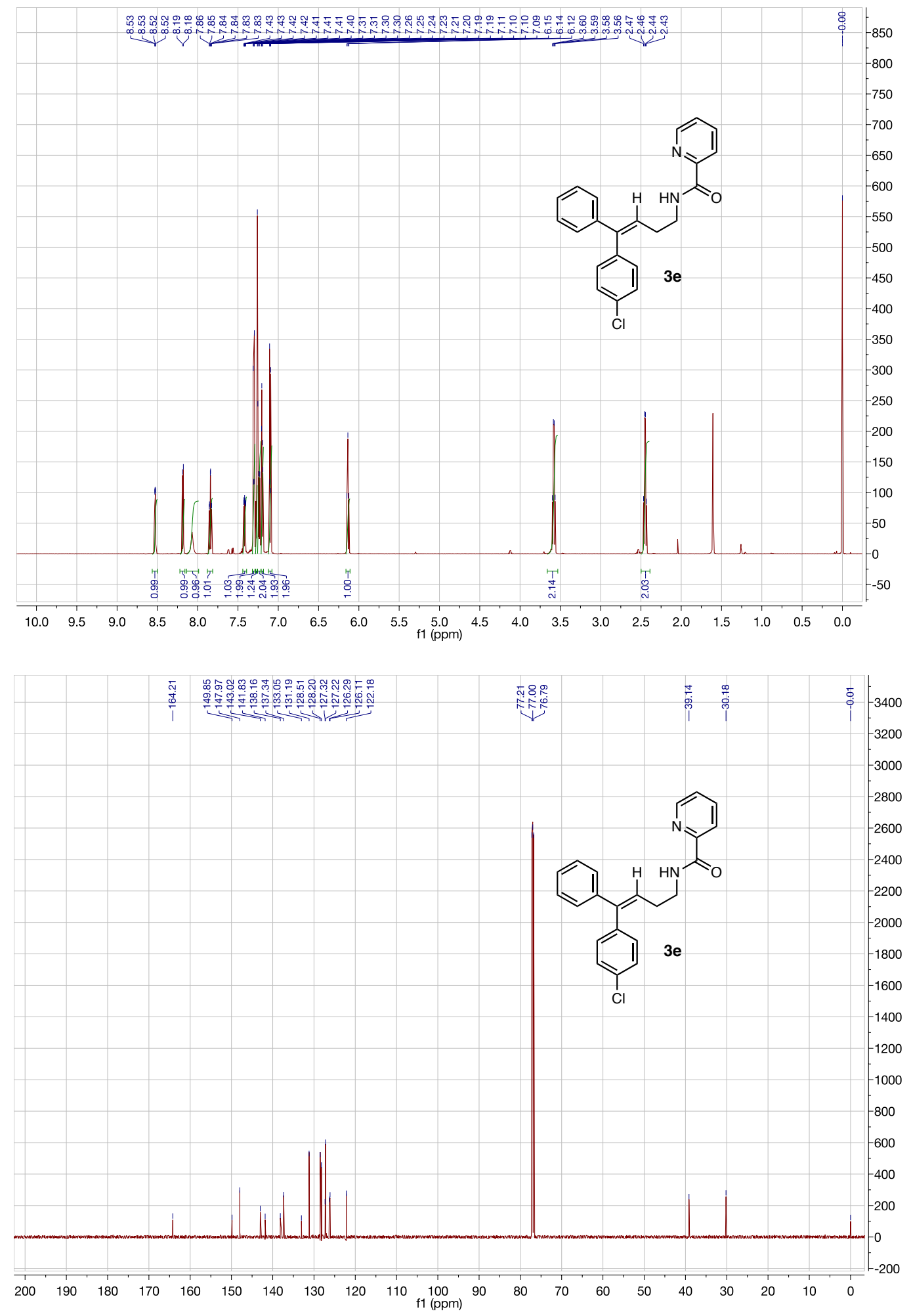

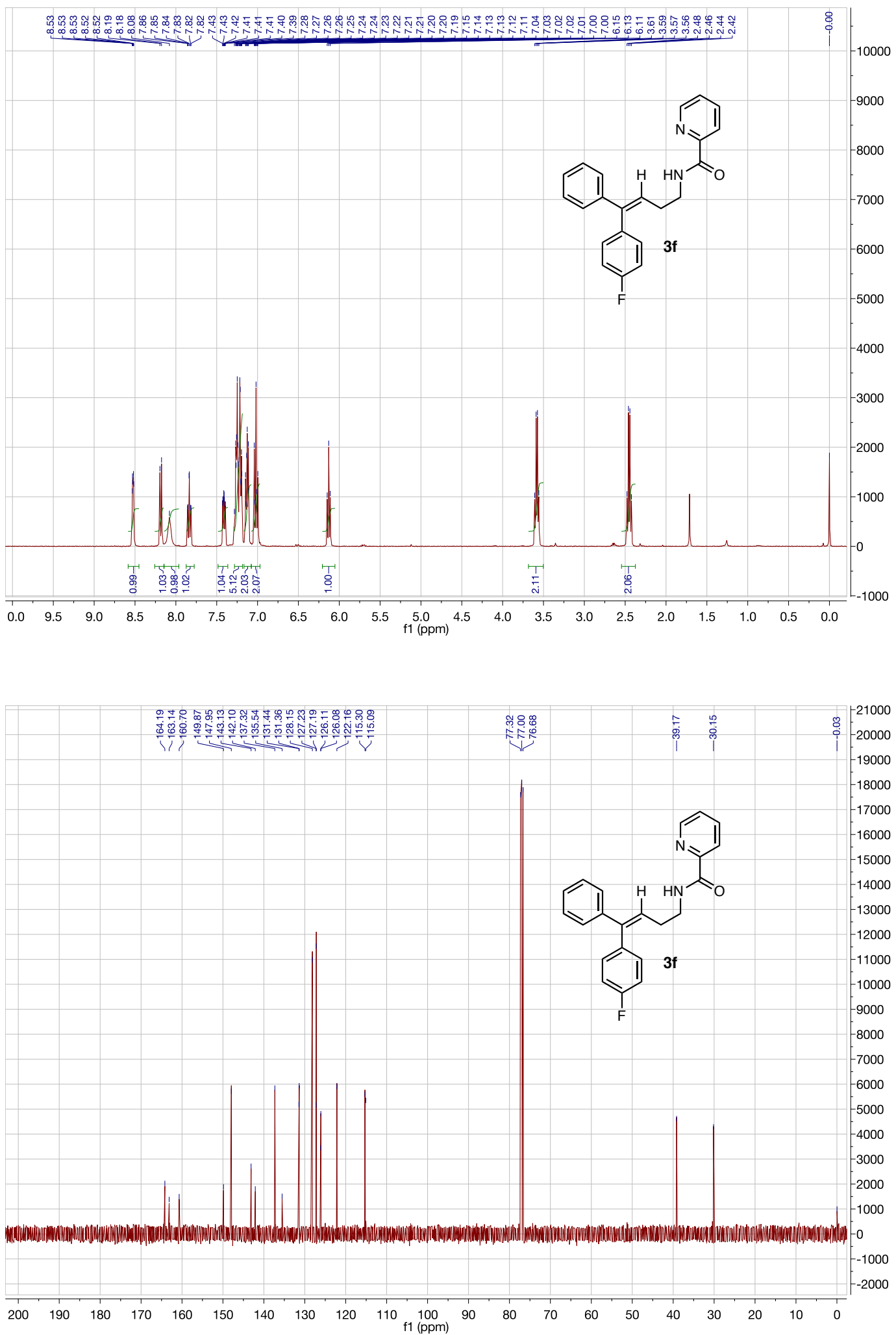

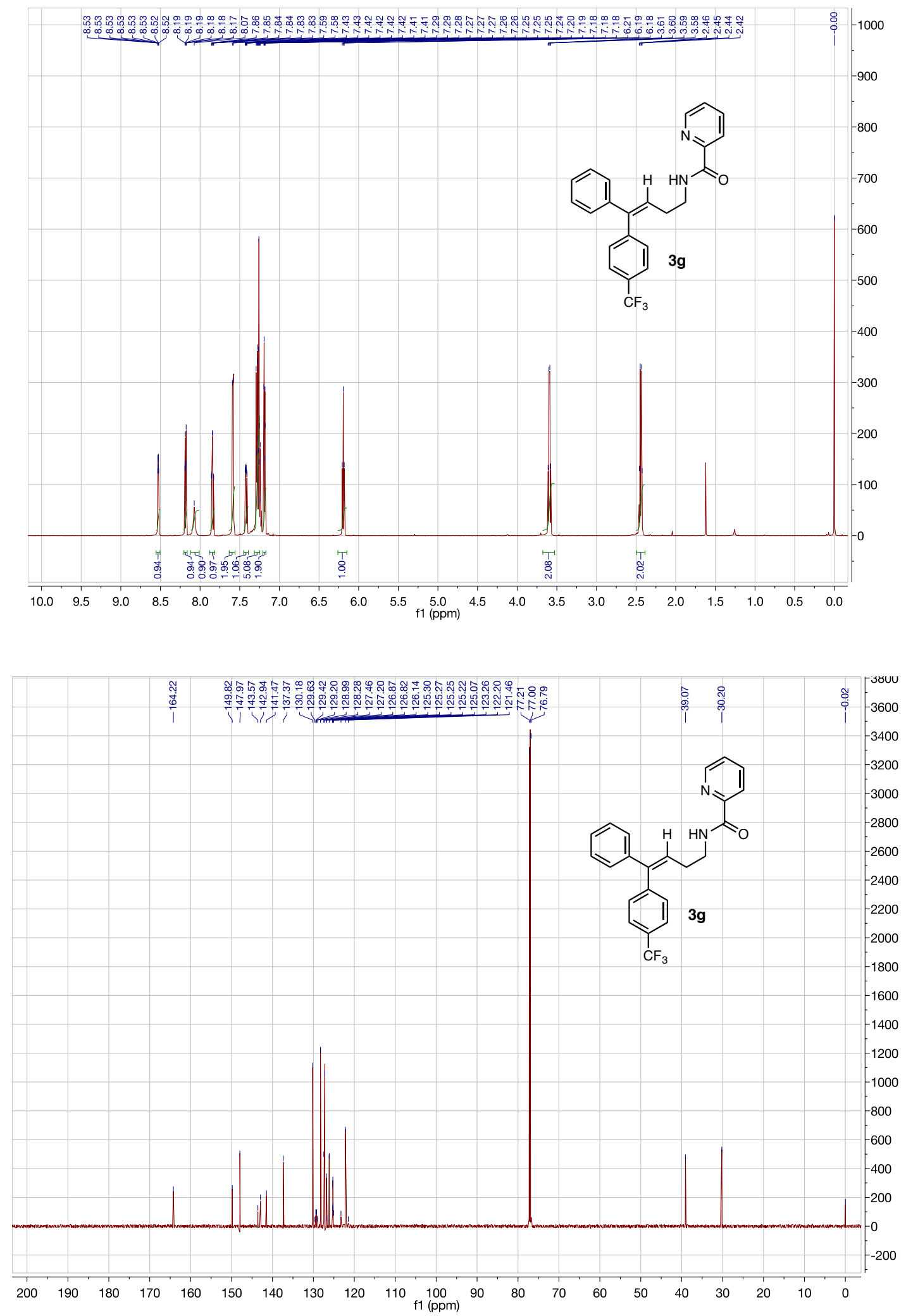

S-100 

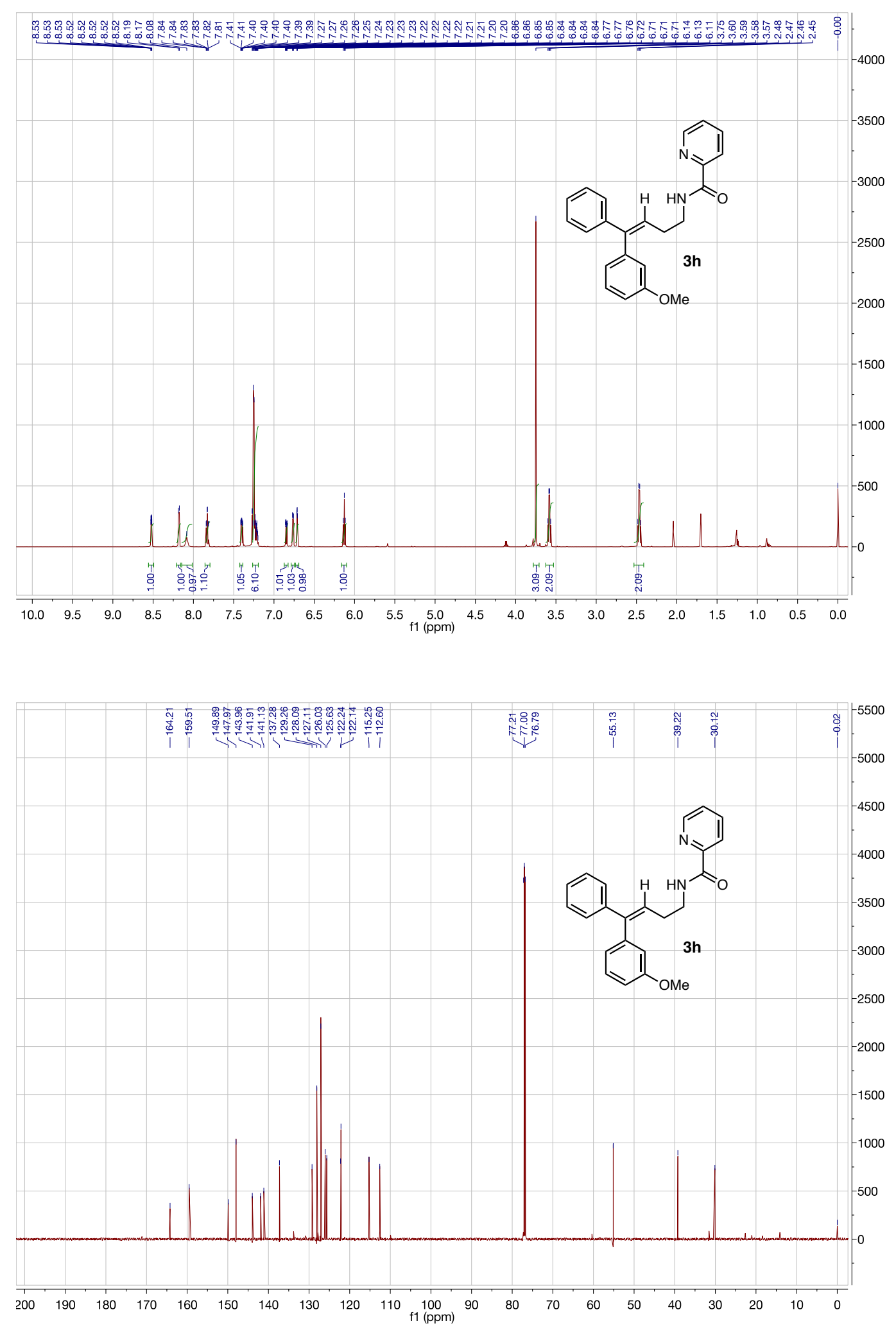

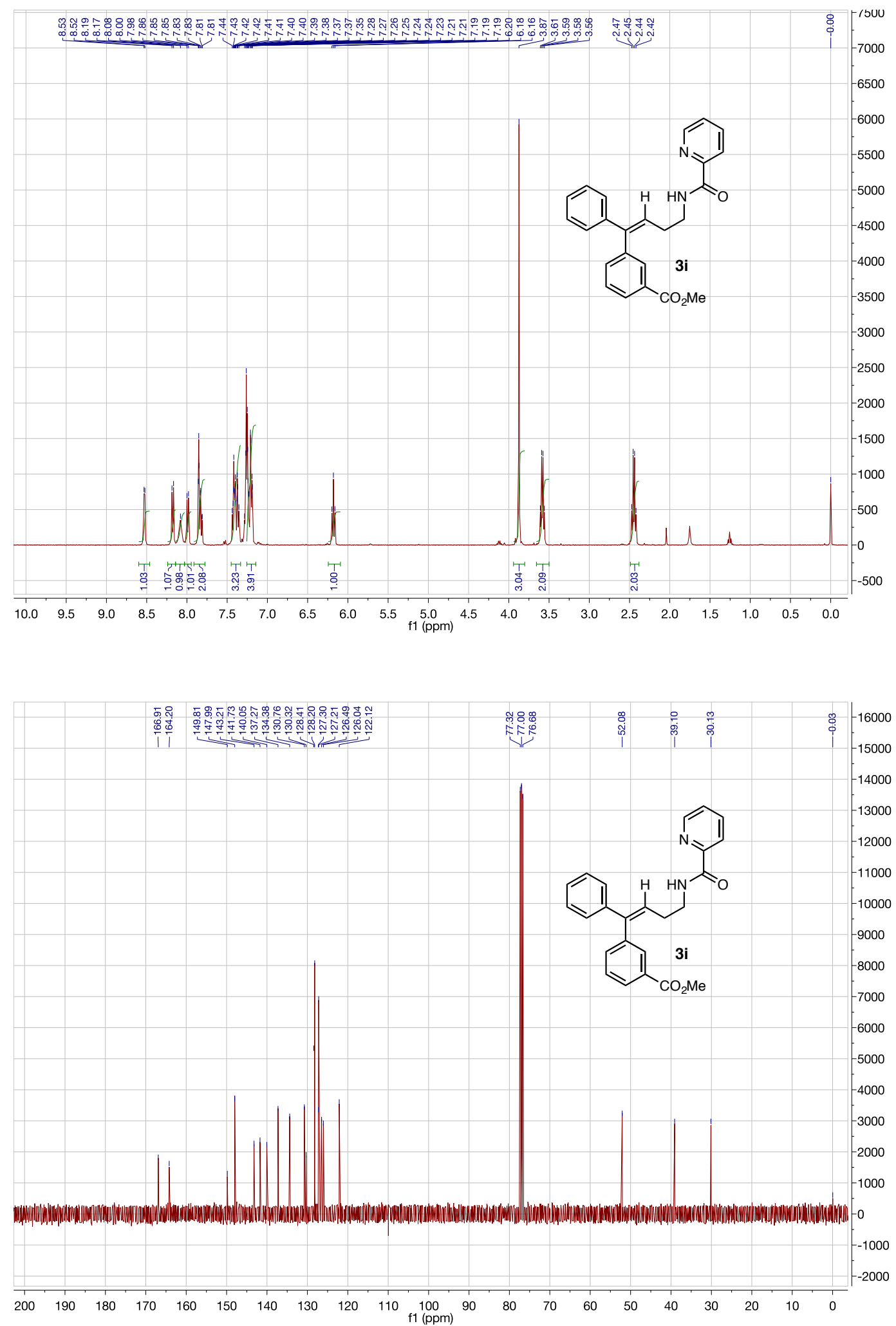

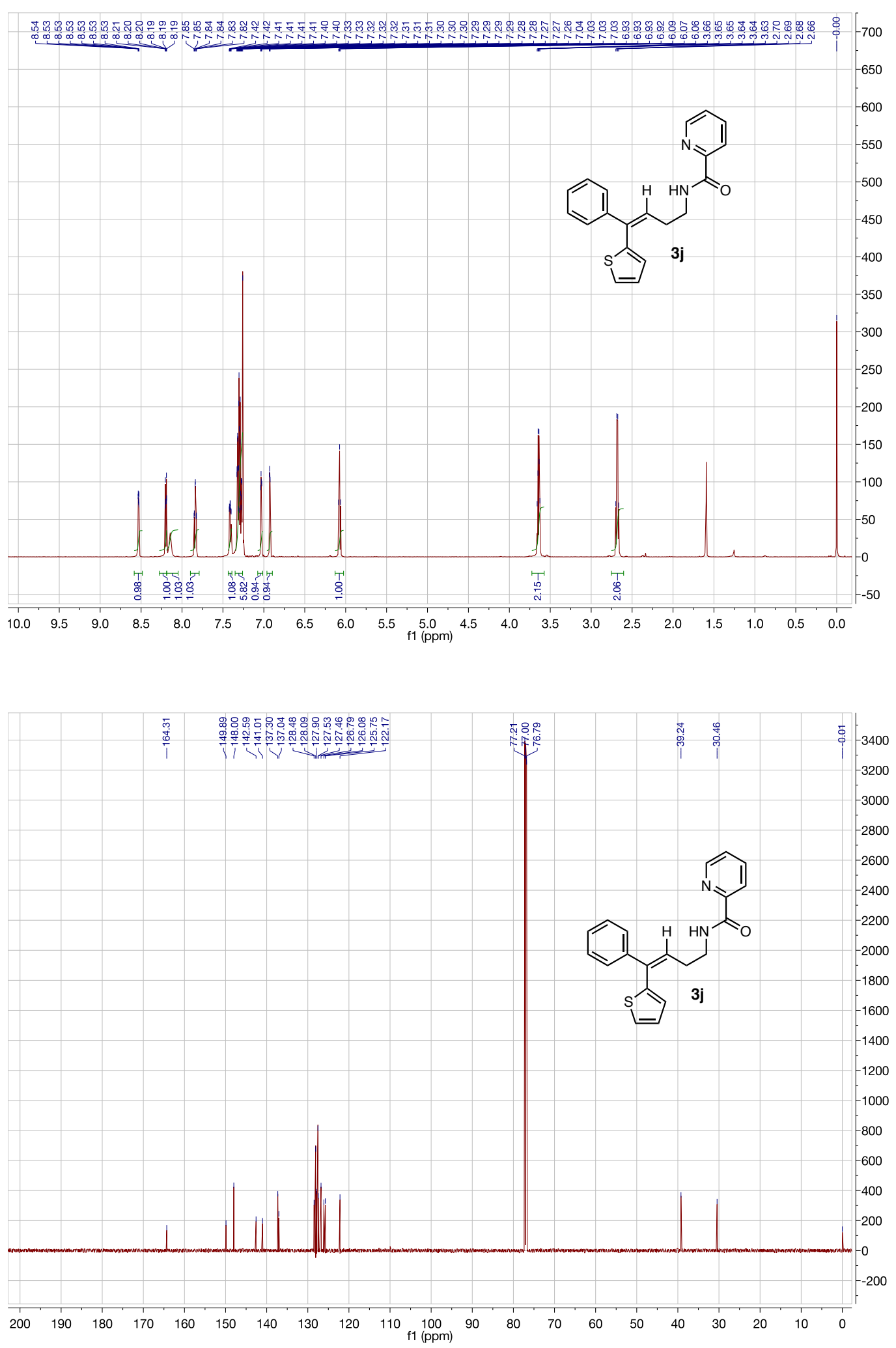

S-103 

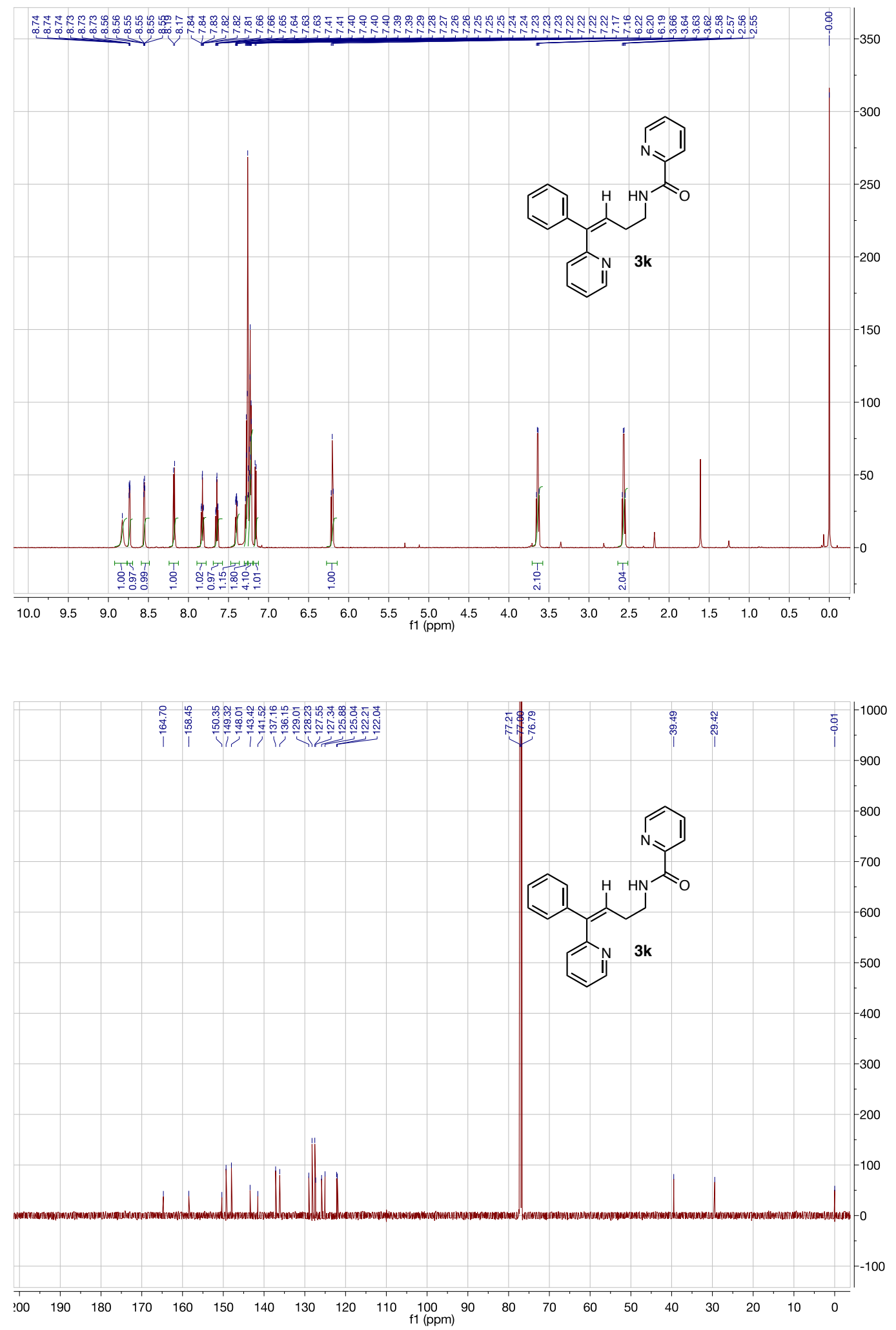

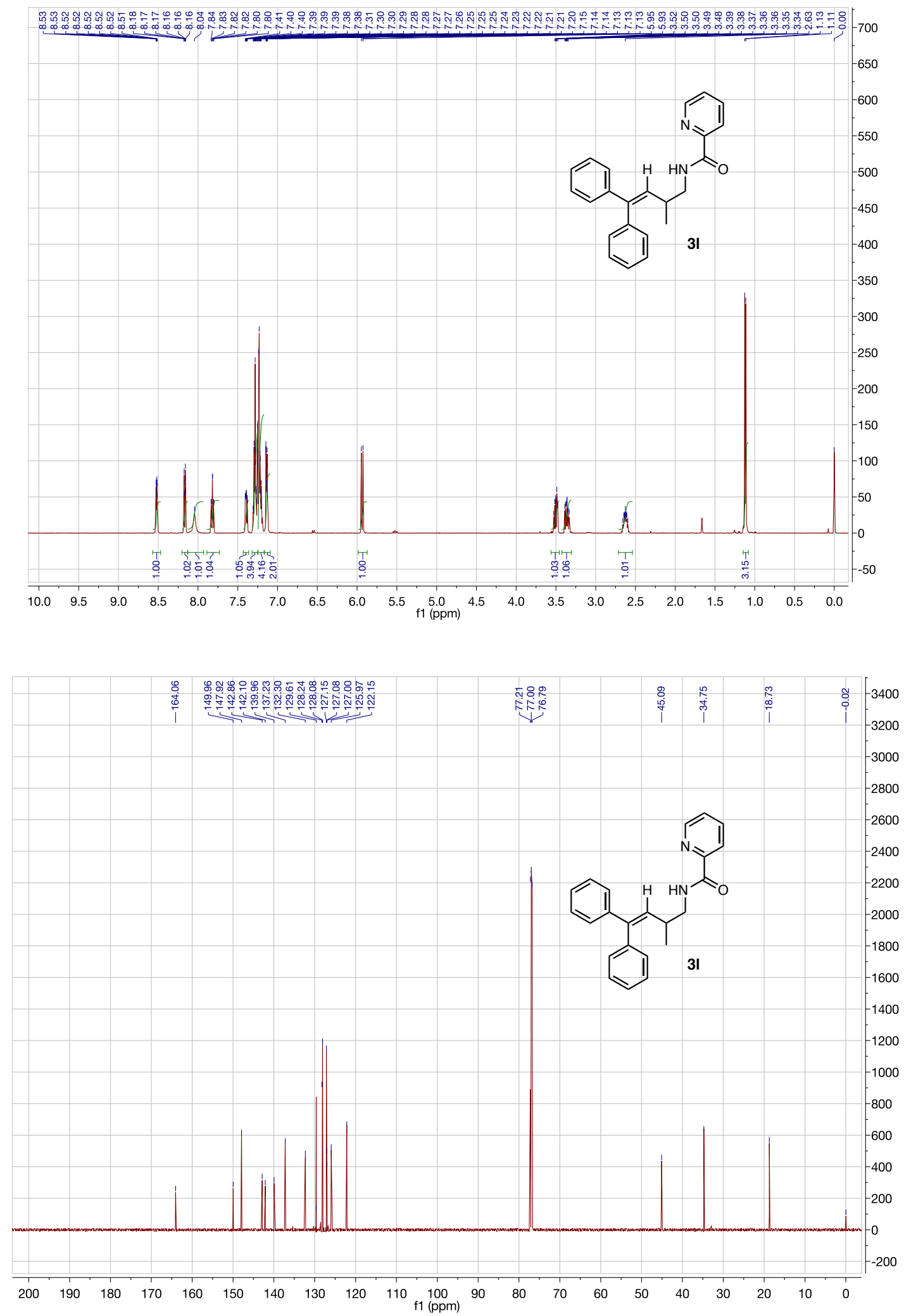

S-105 

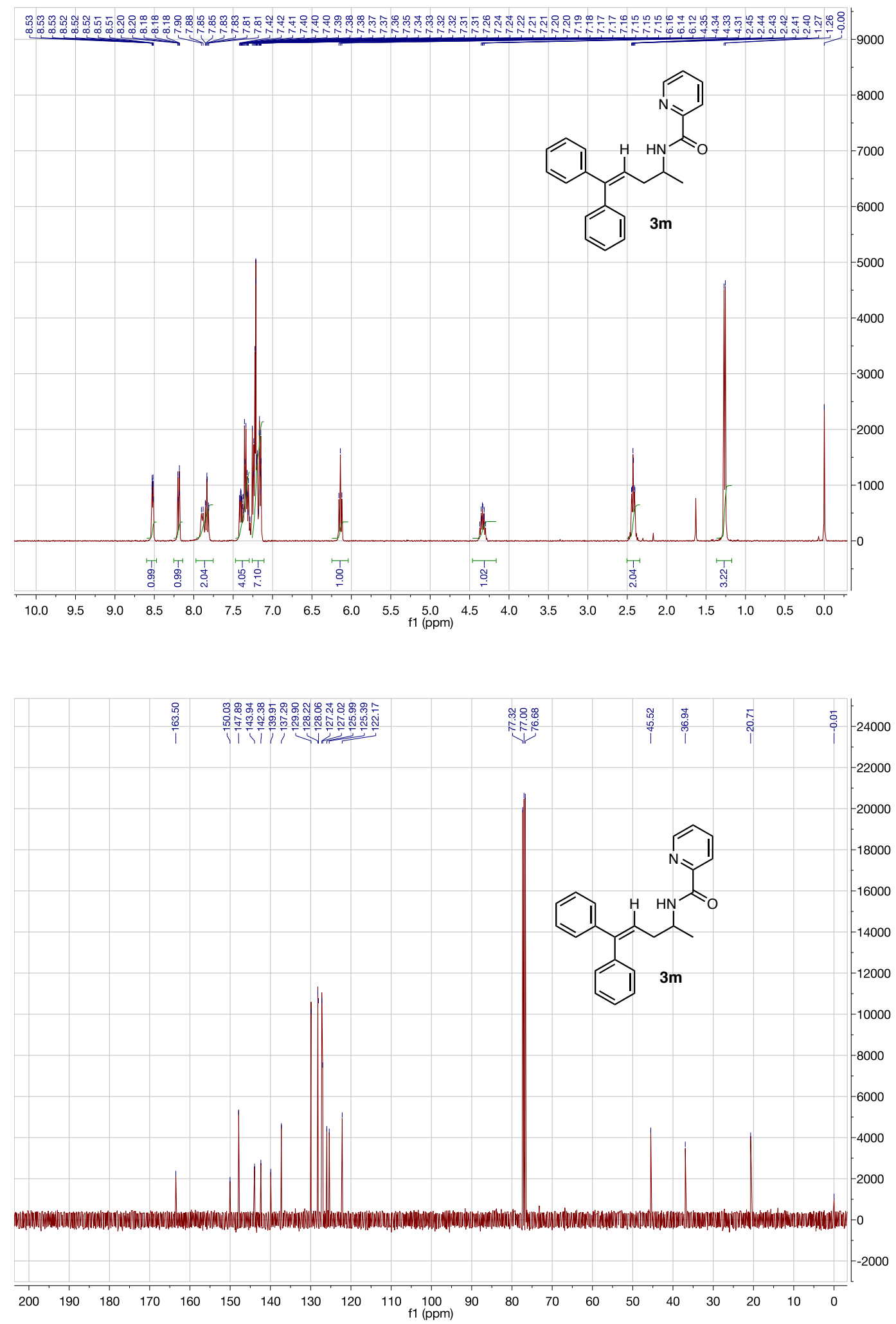

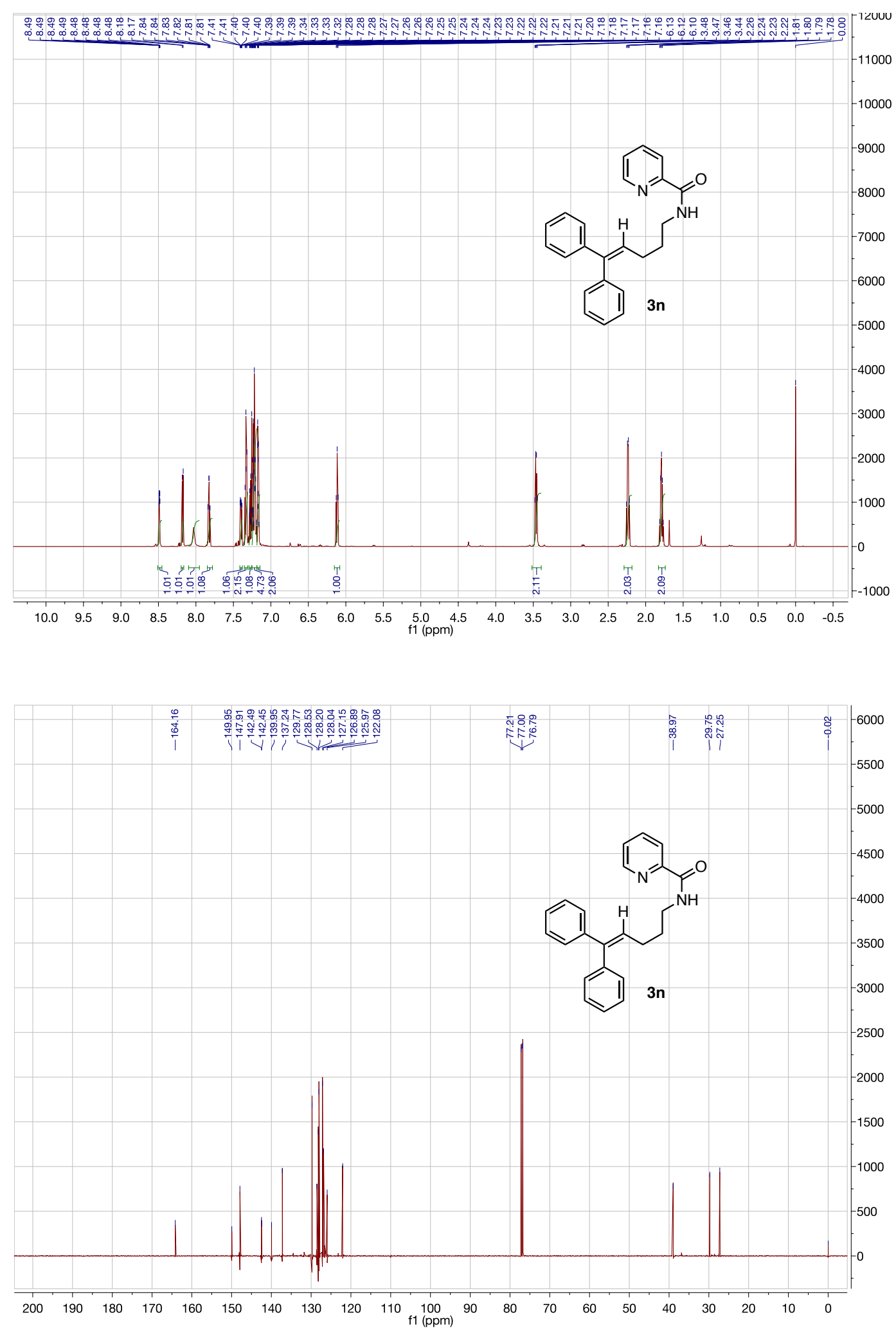

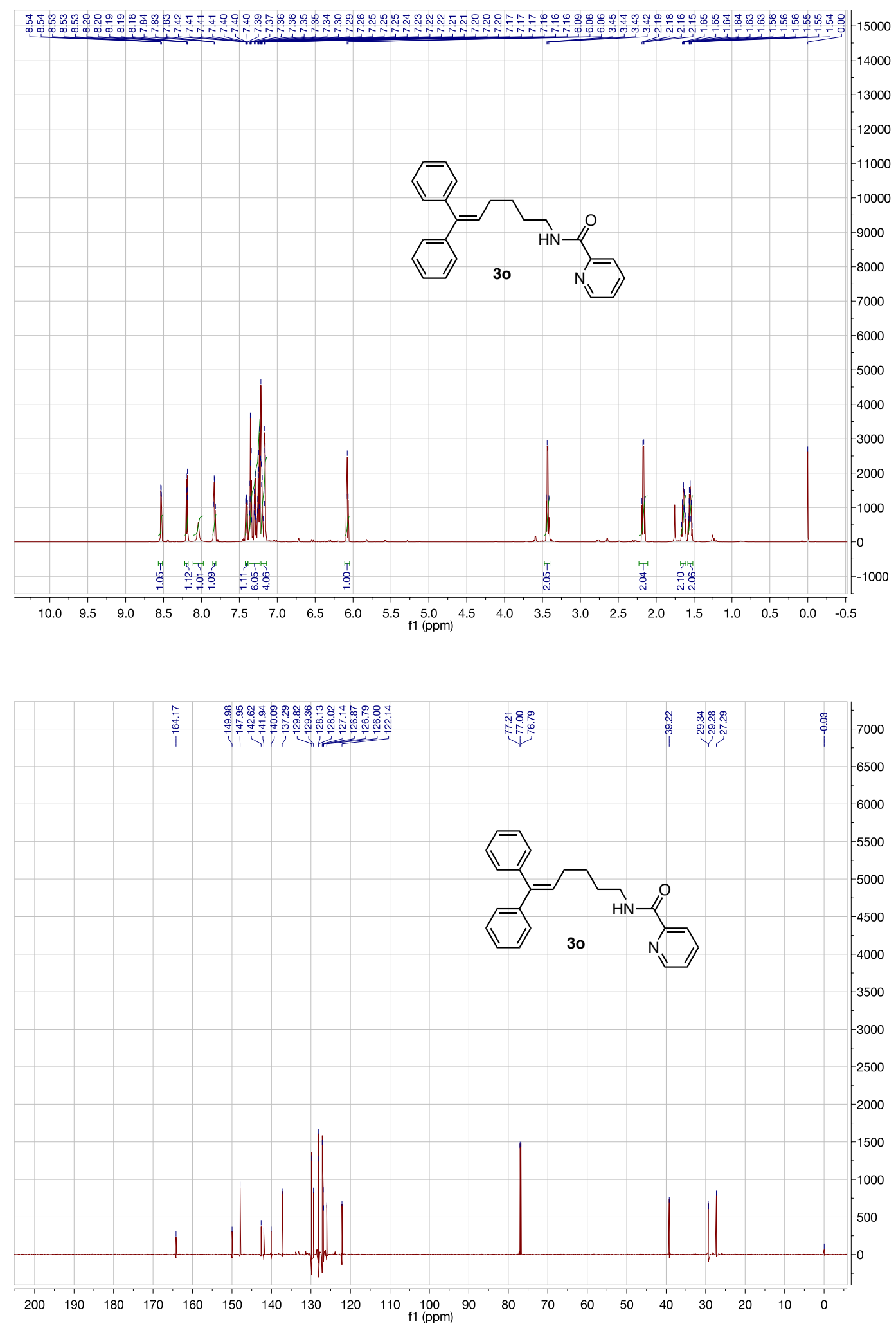

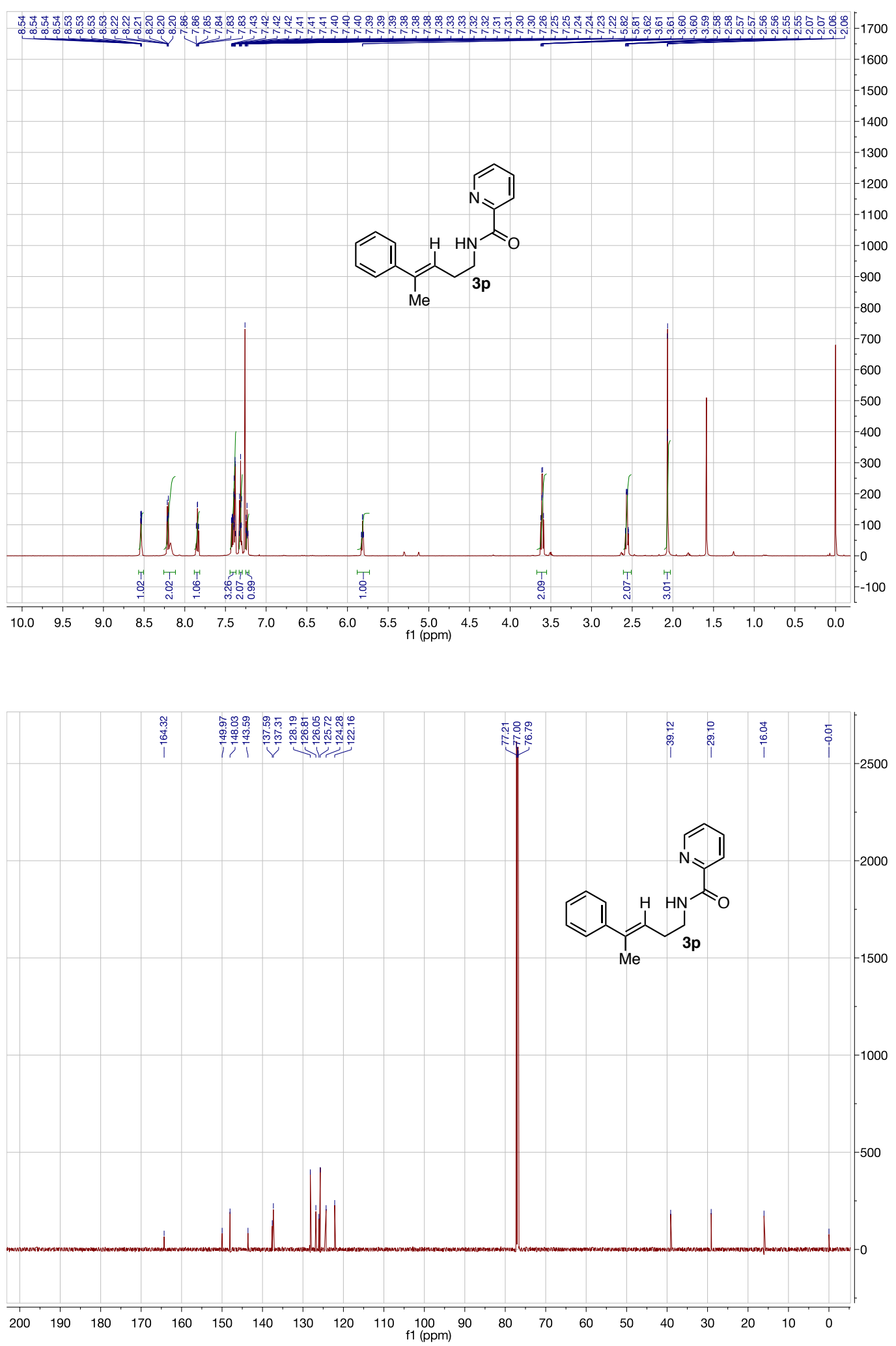

S-109 

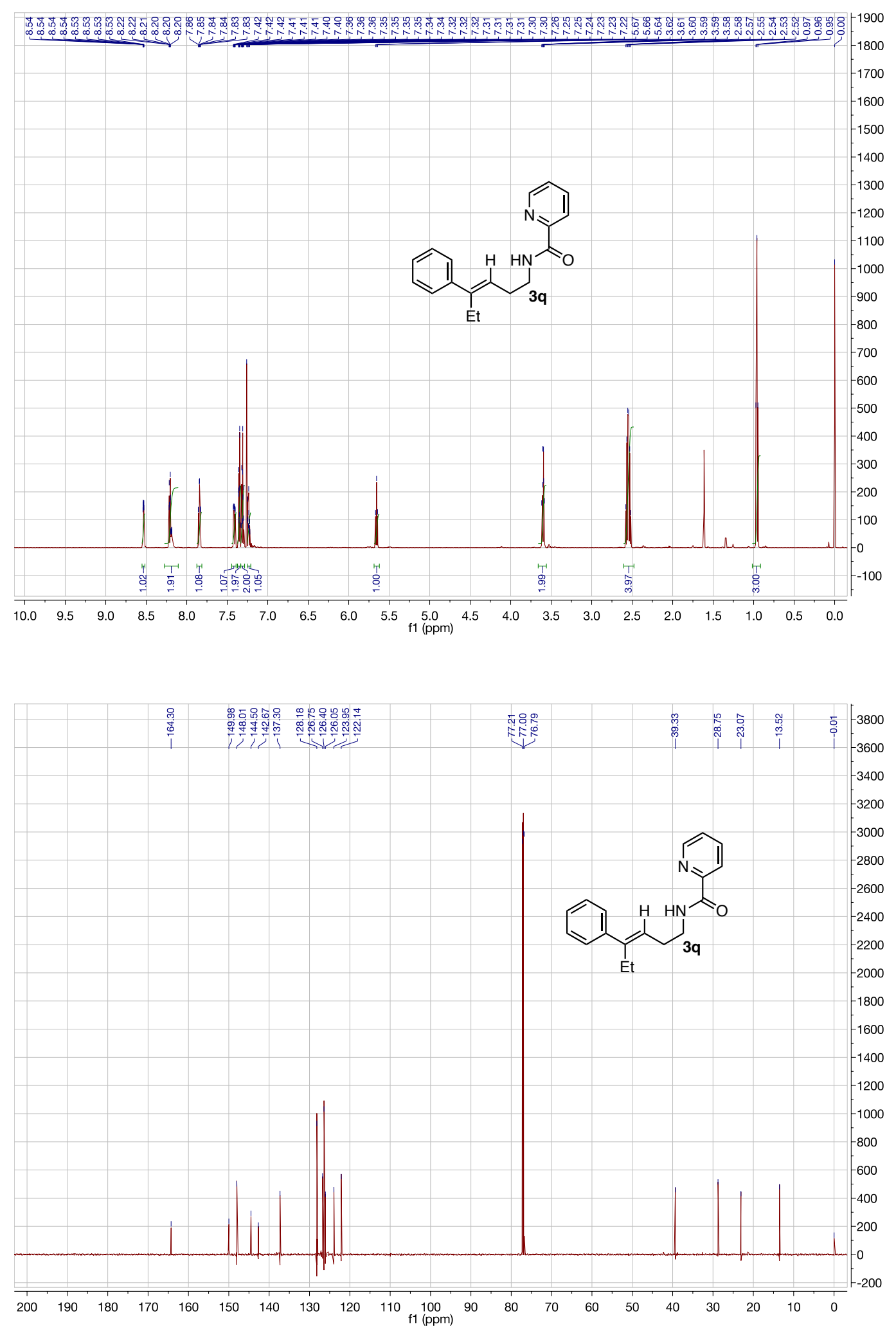

S-110 

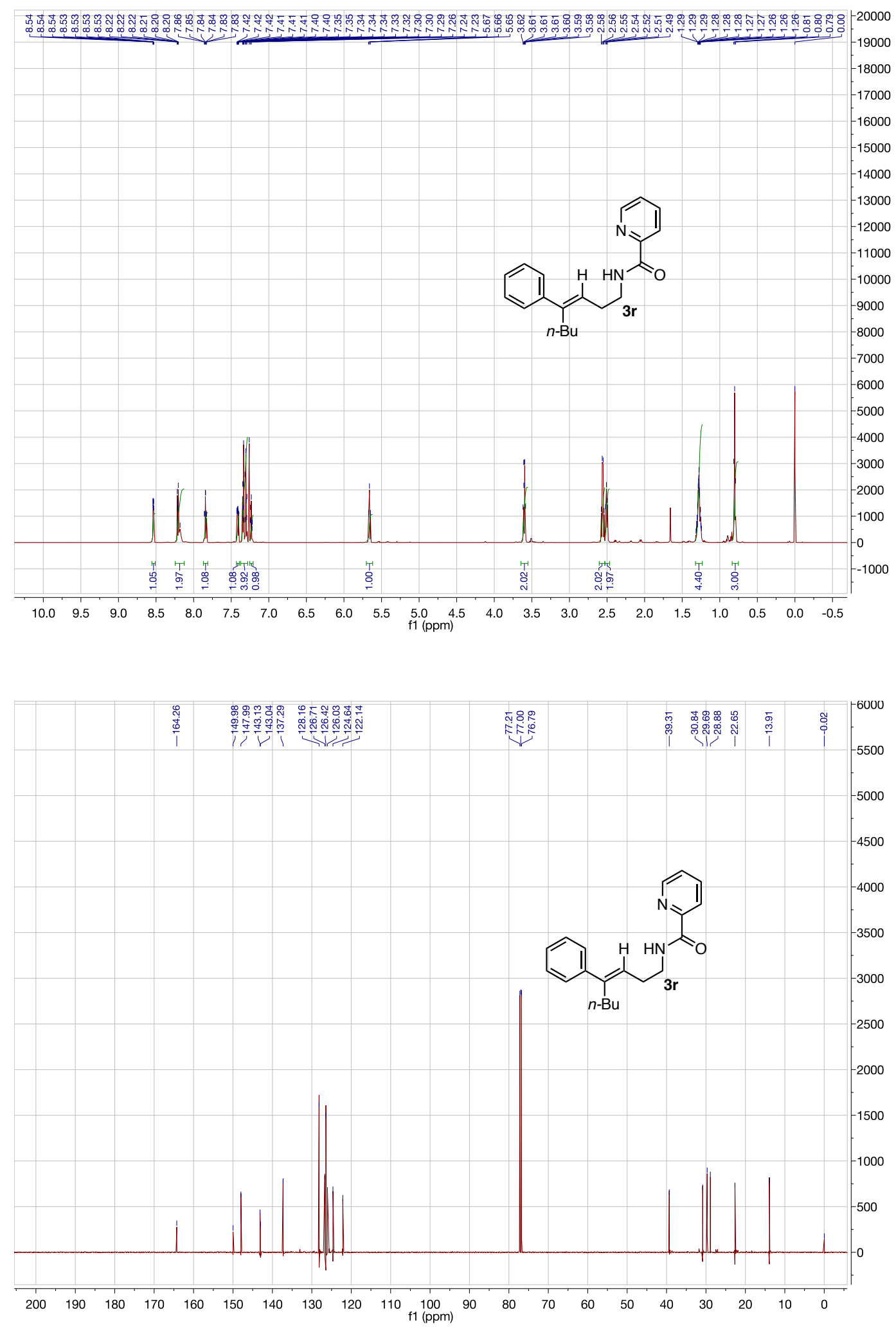

S-111 

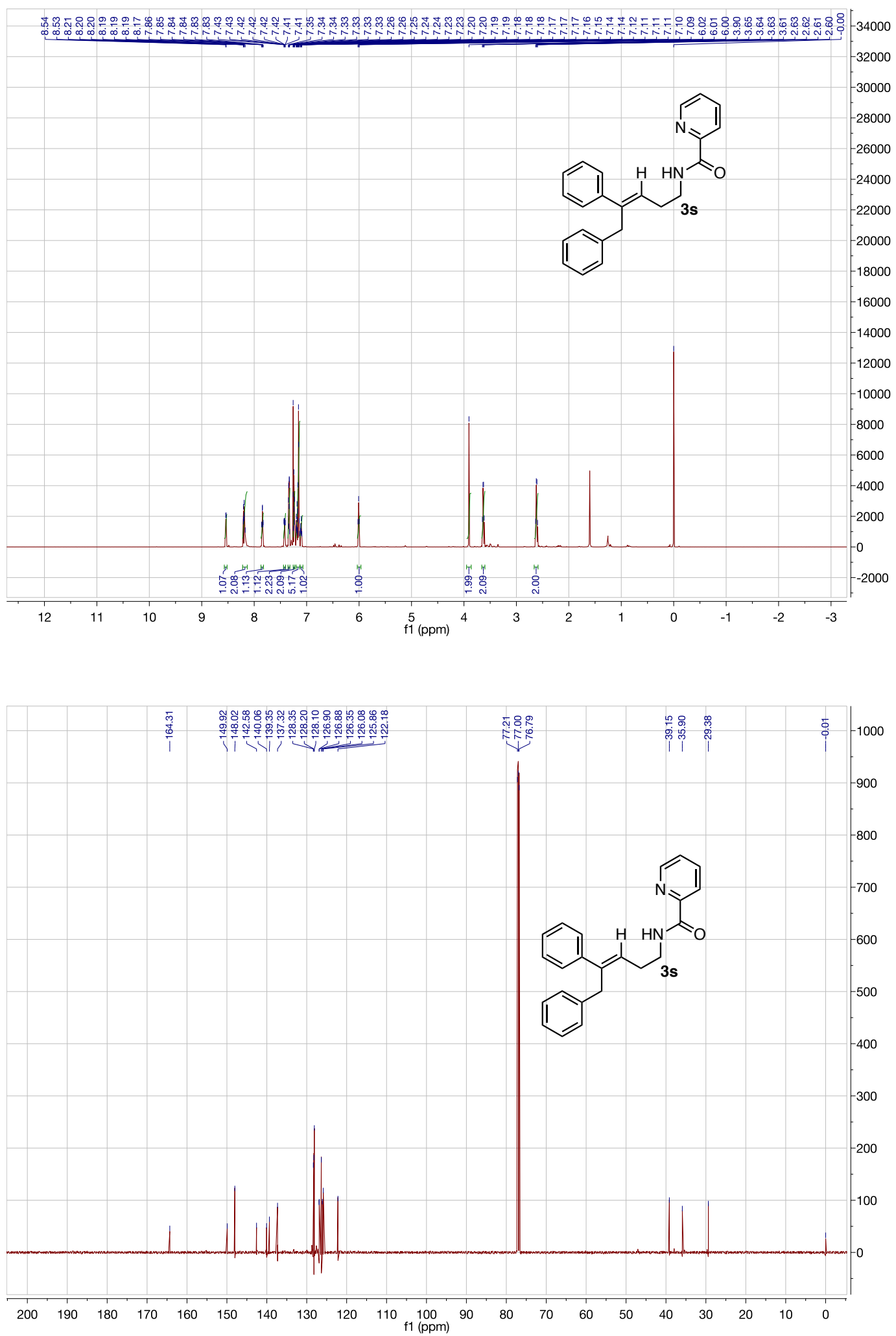

S-112 

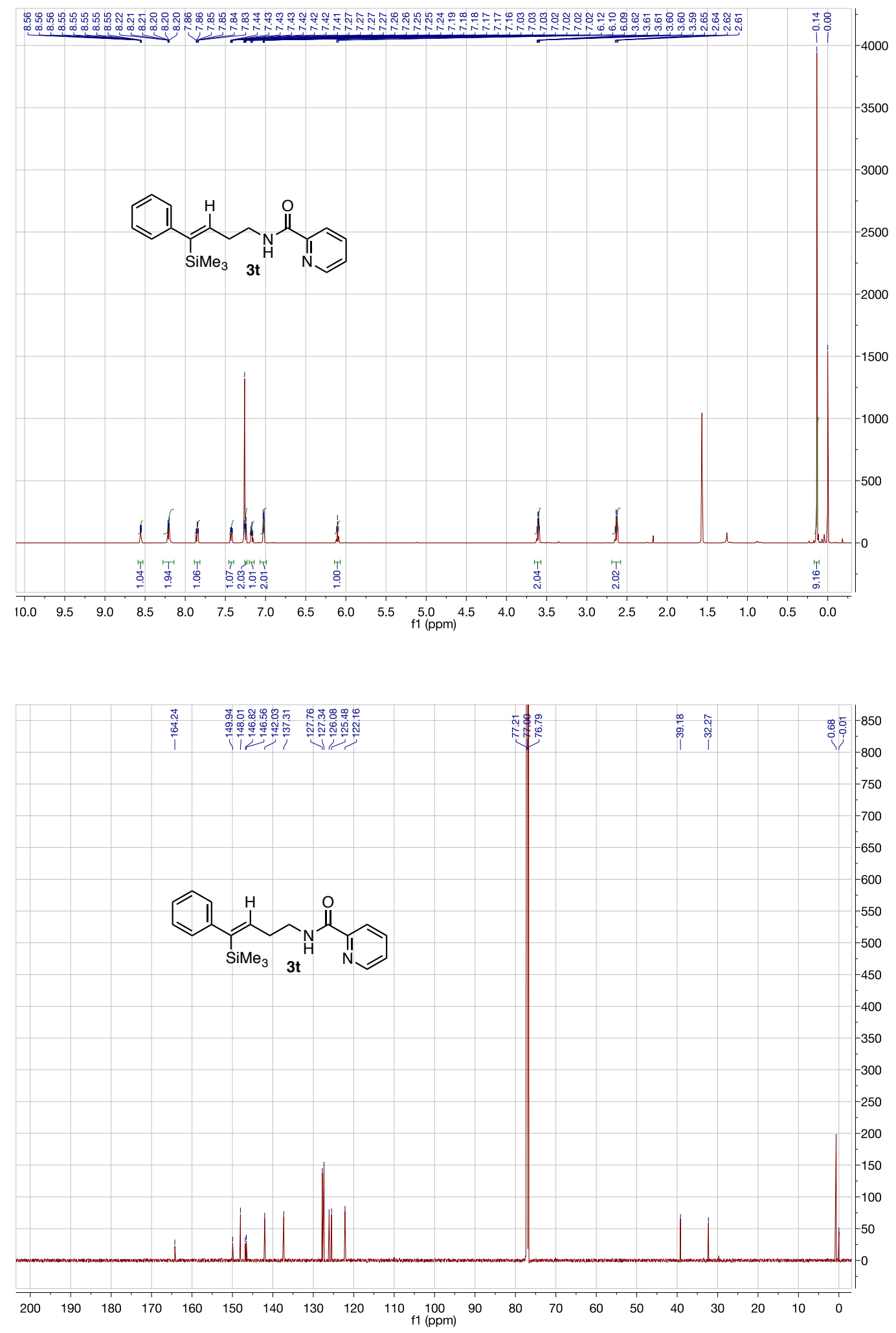

S-113 

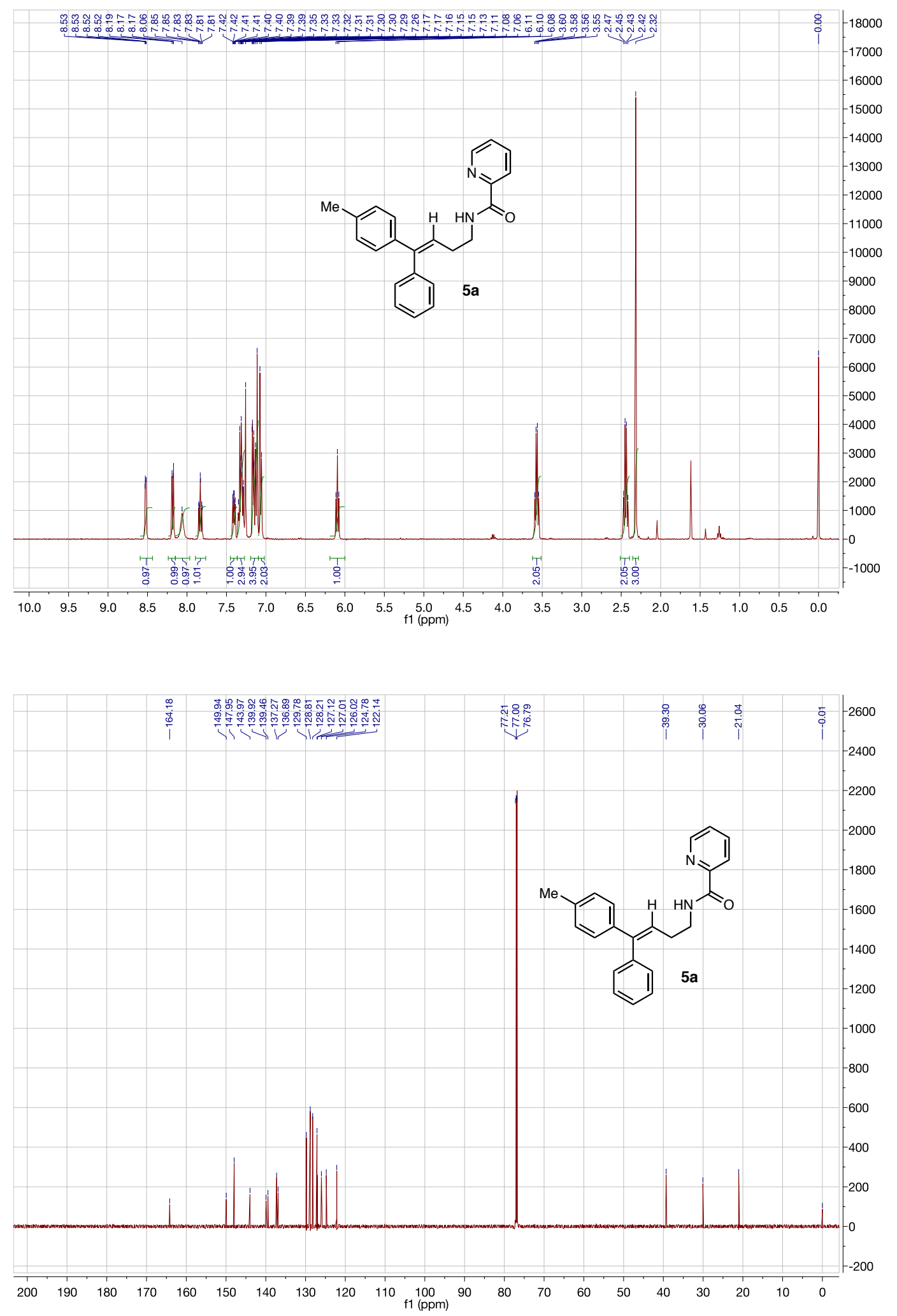

S-114 

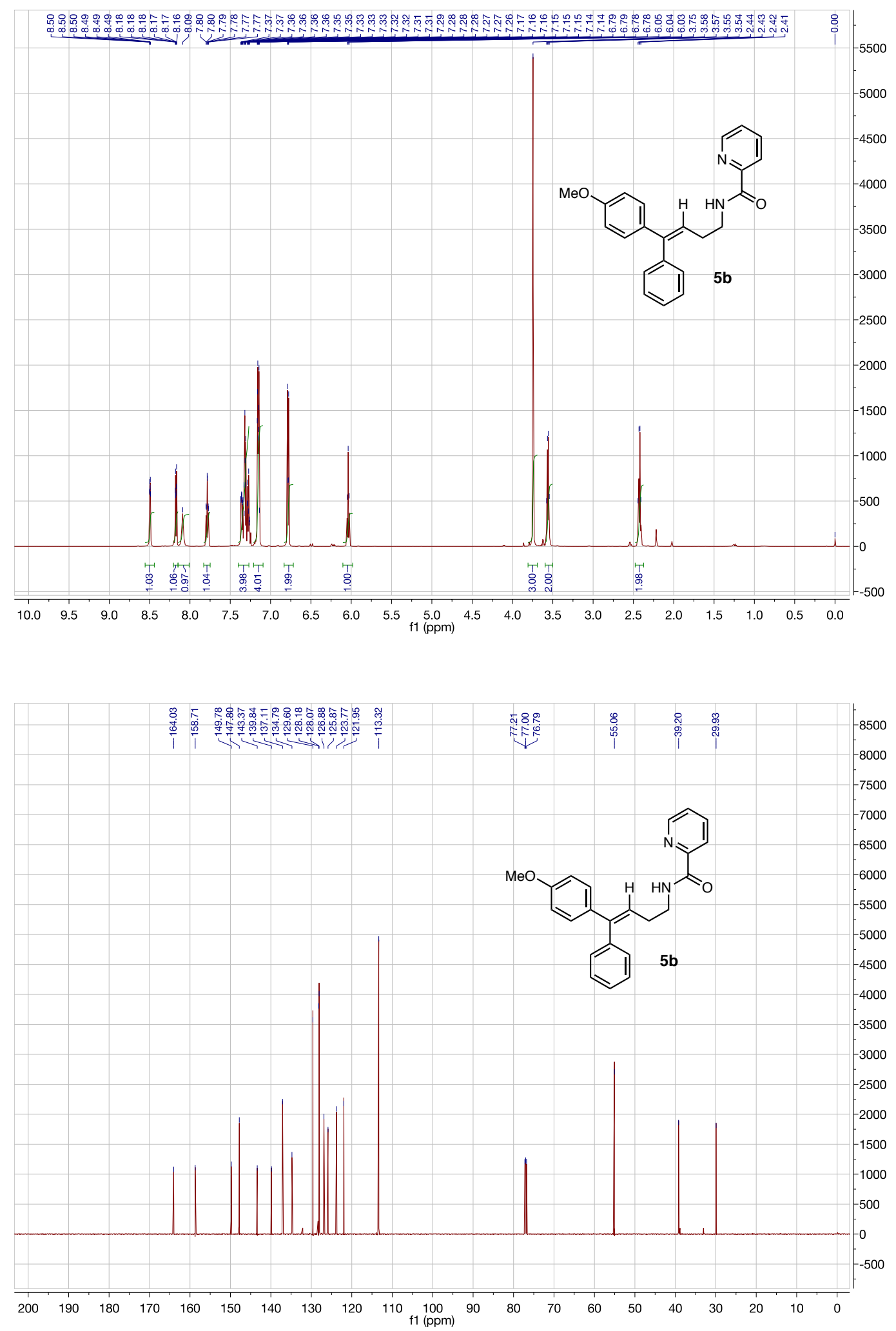

S-115 

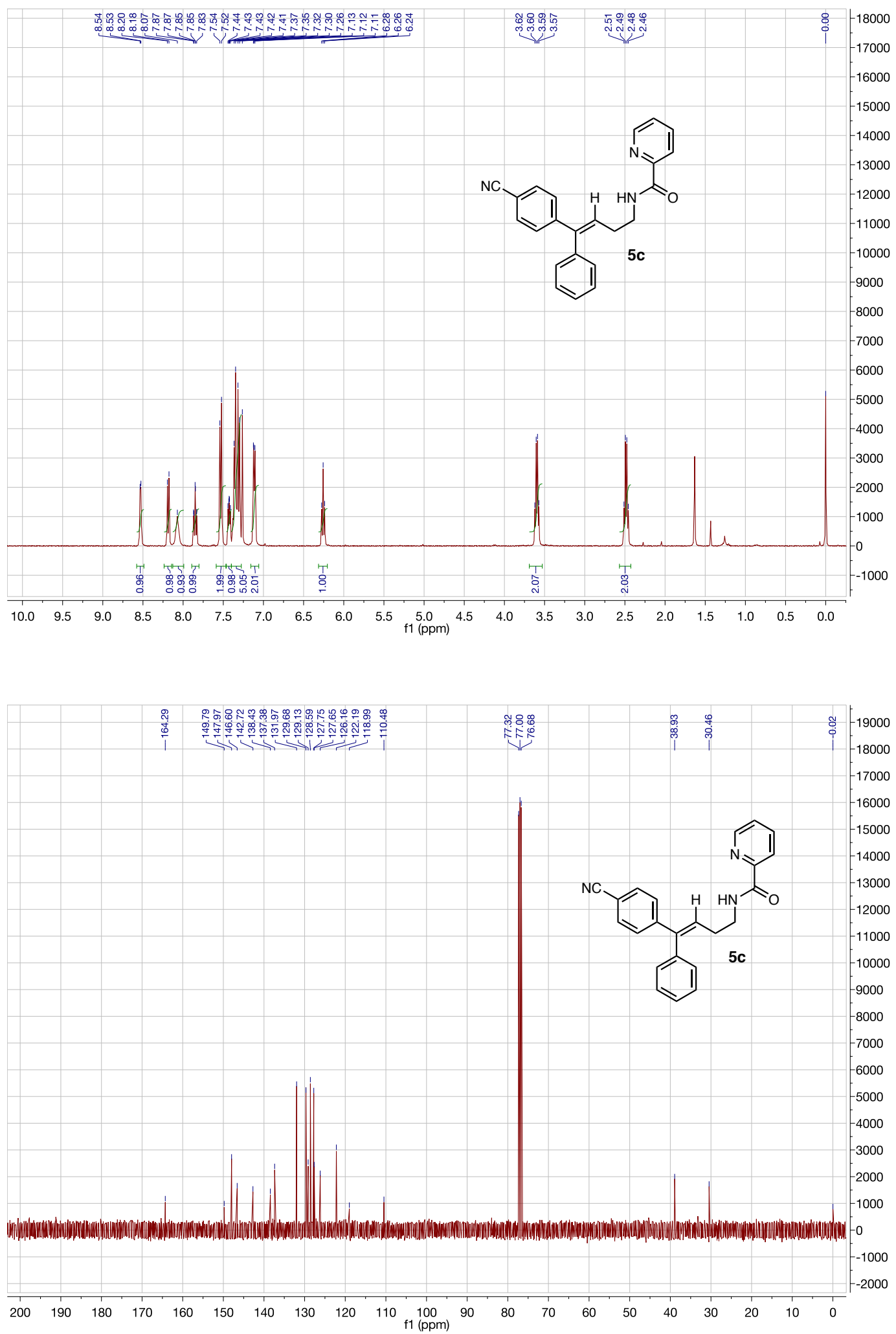

S-116 

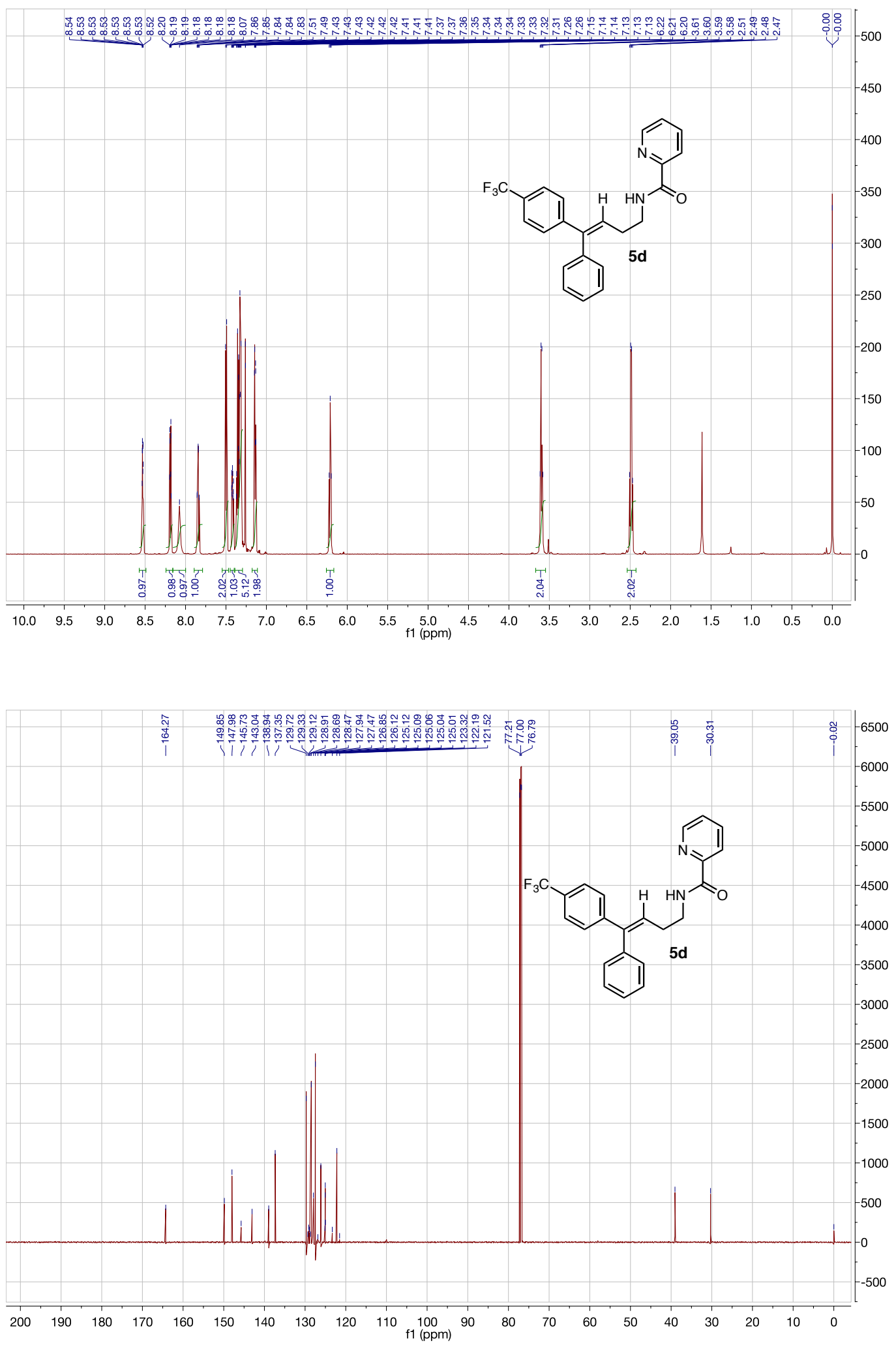

S-117 

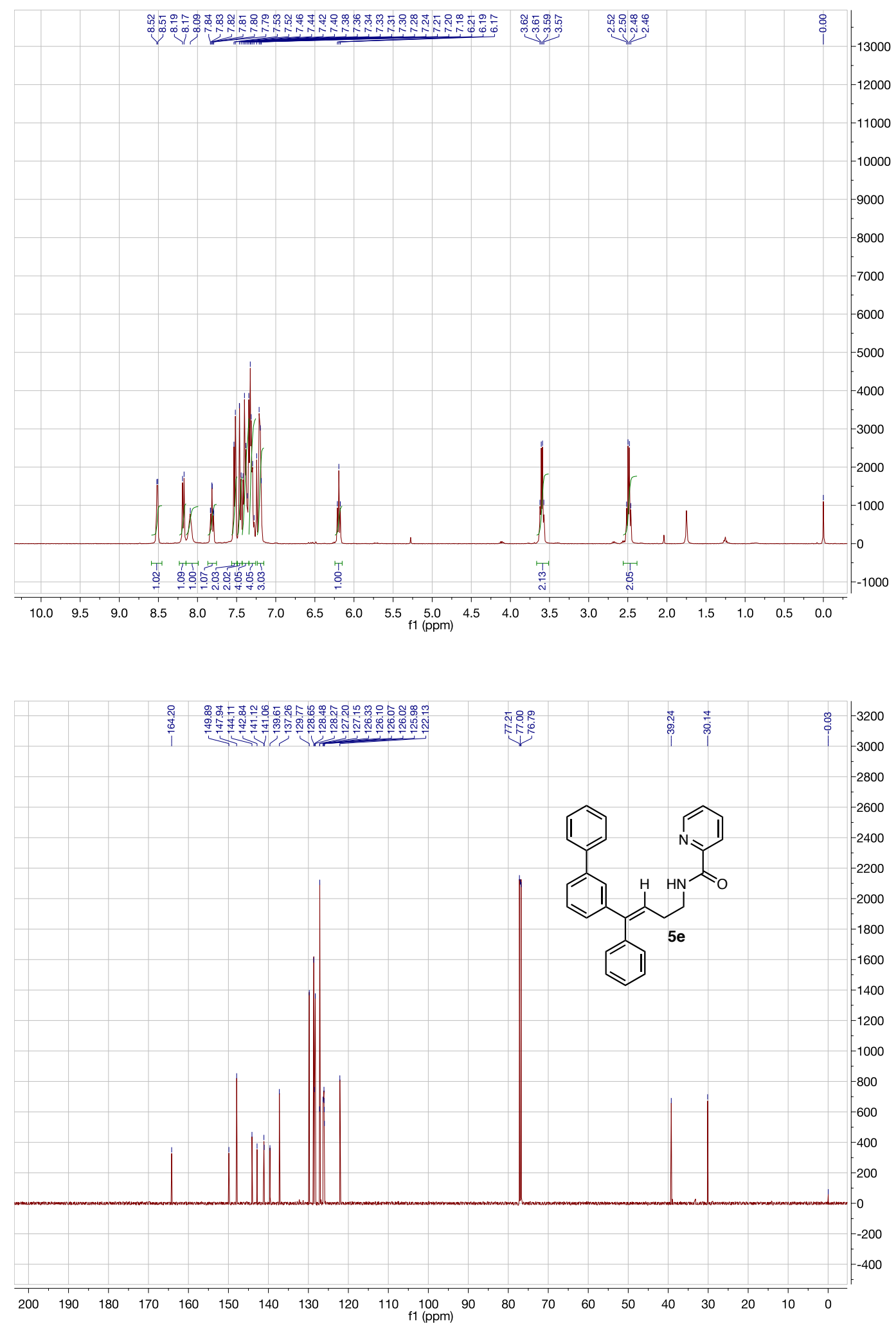

S-118 

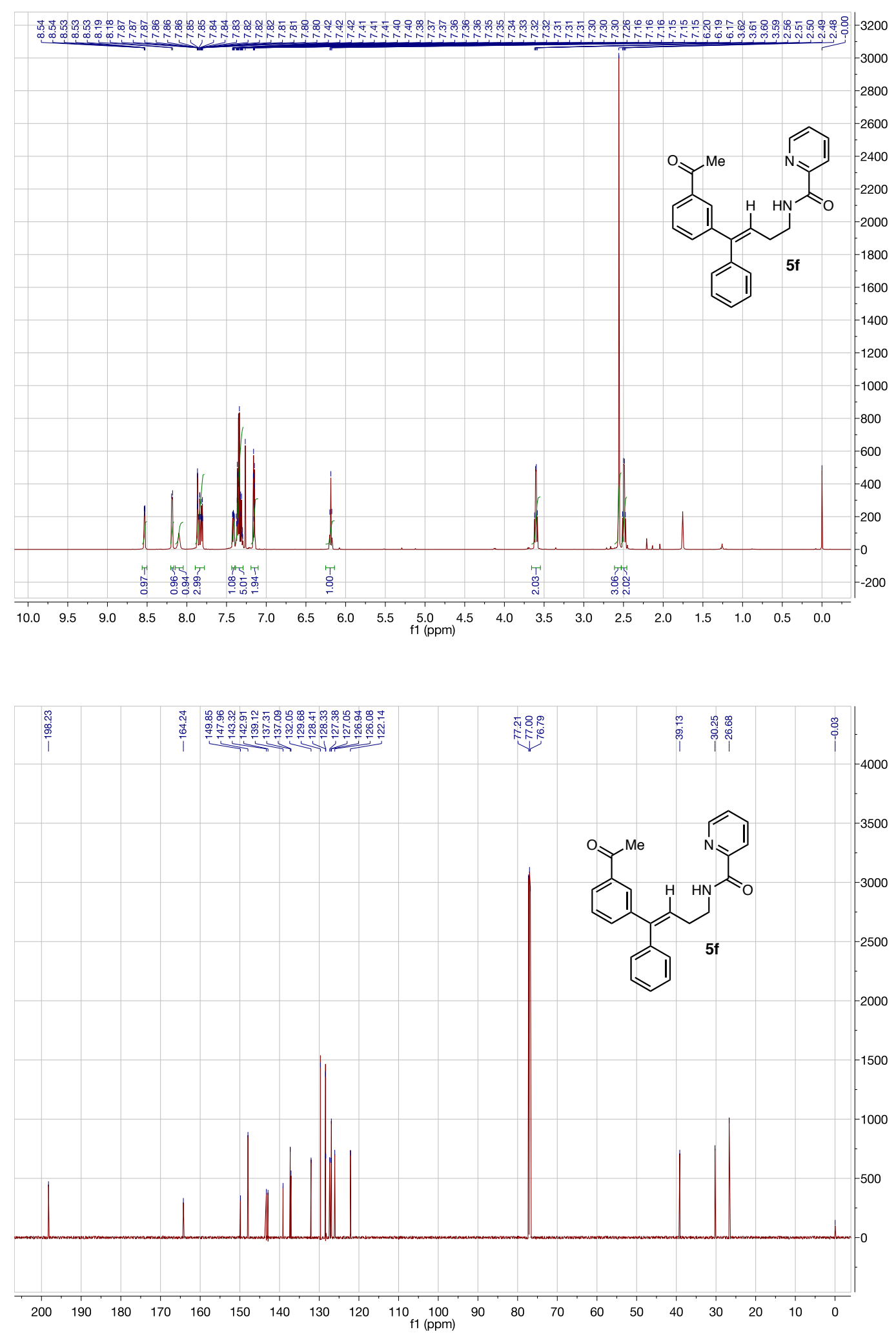

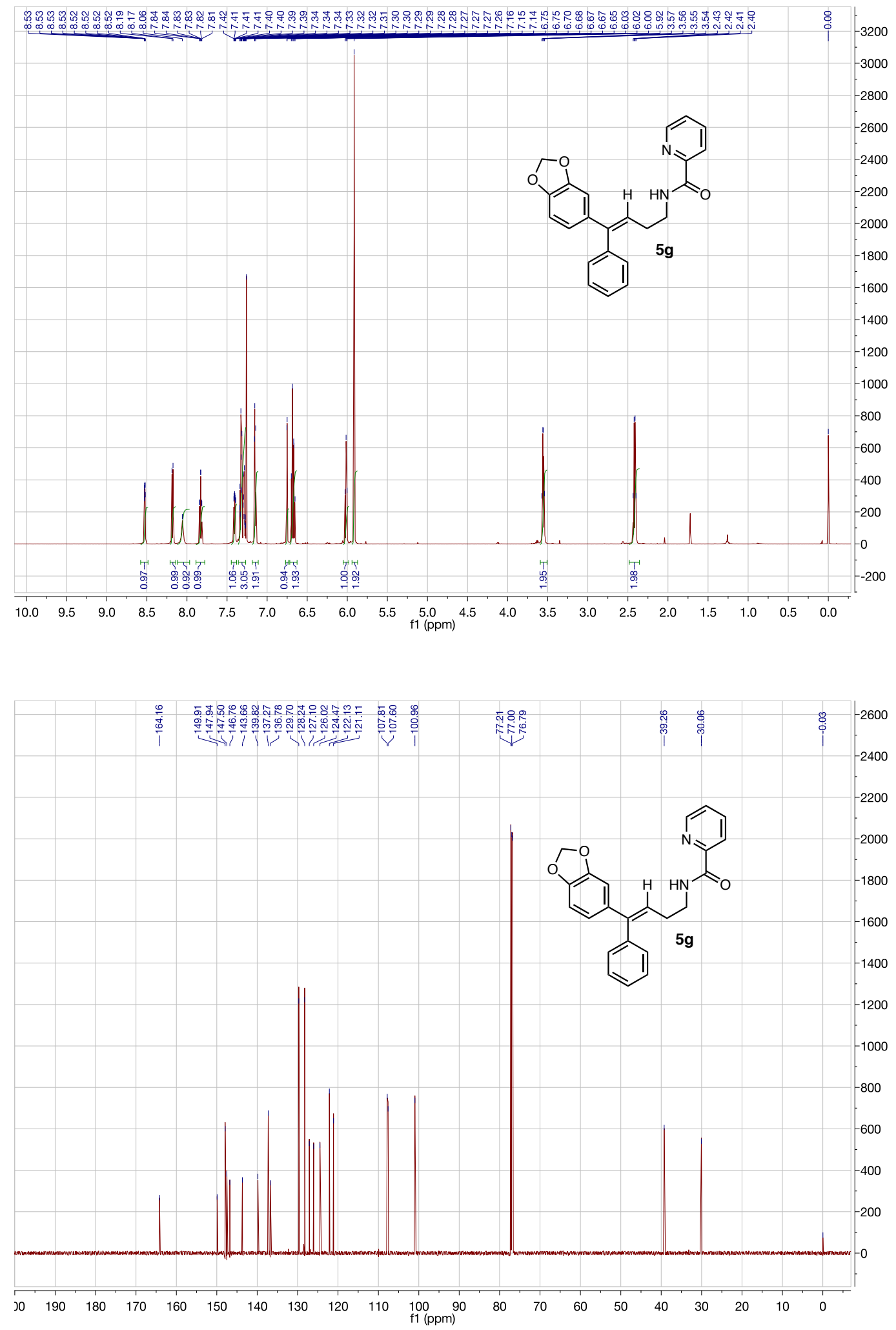

S-120 

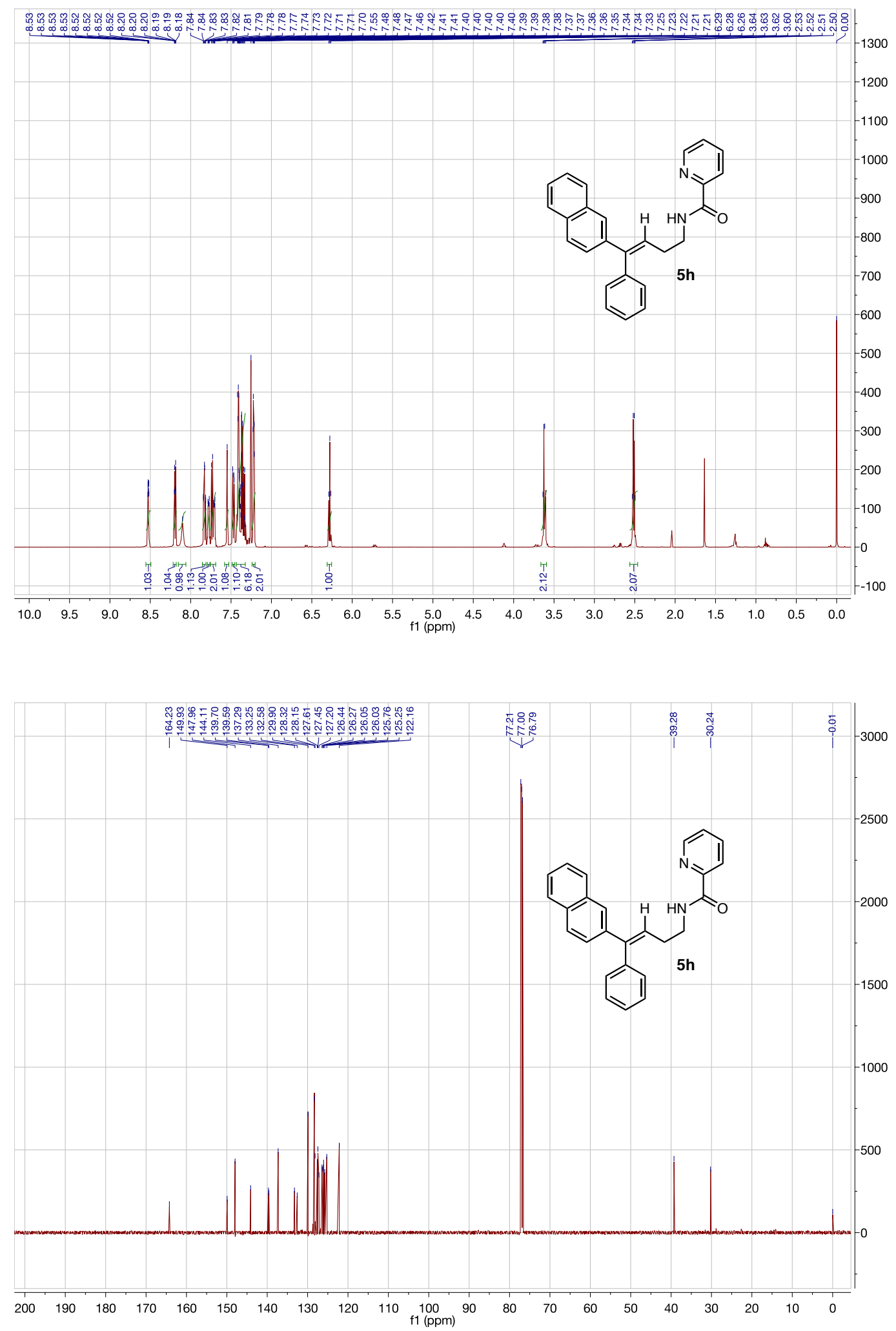

S-121 

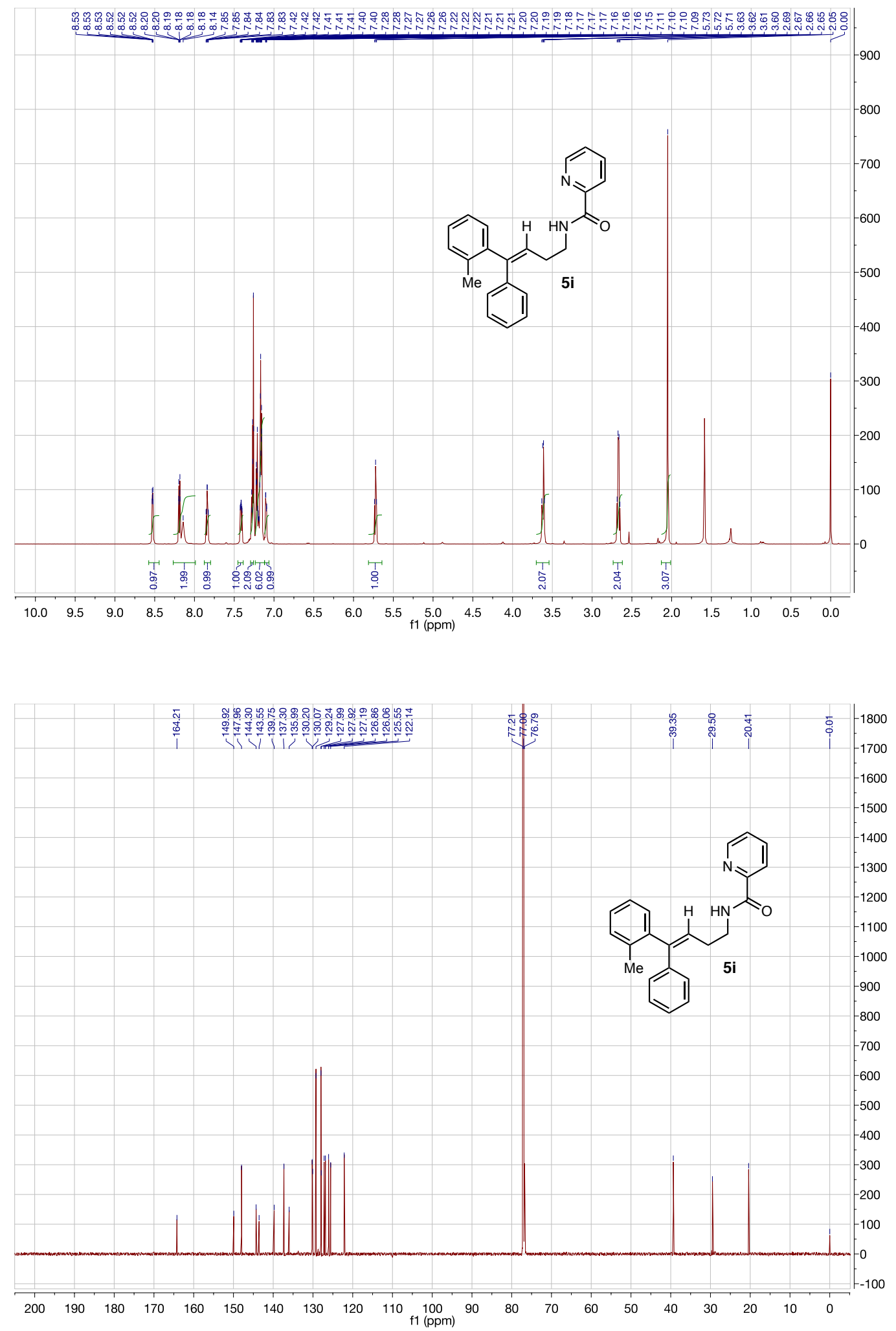

S-122 

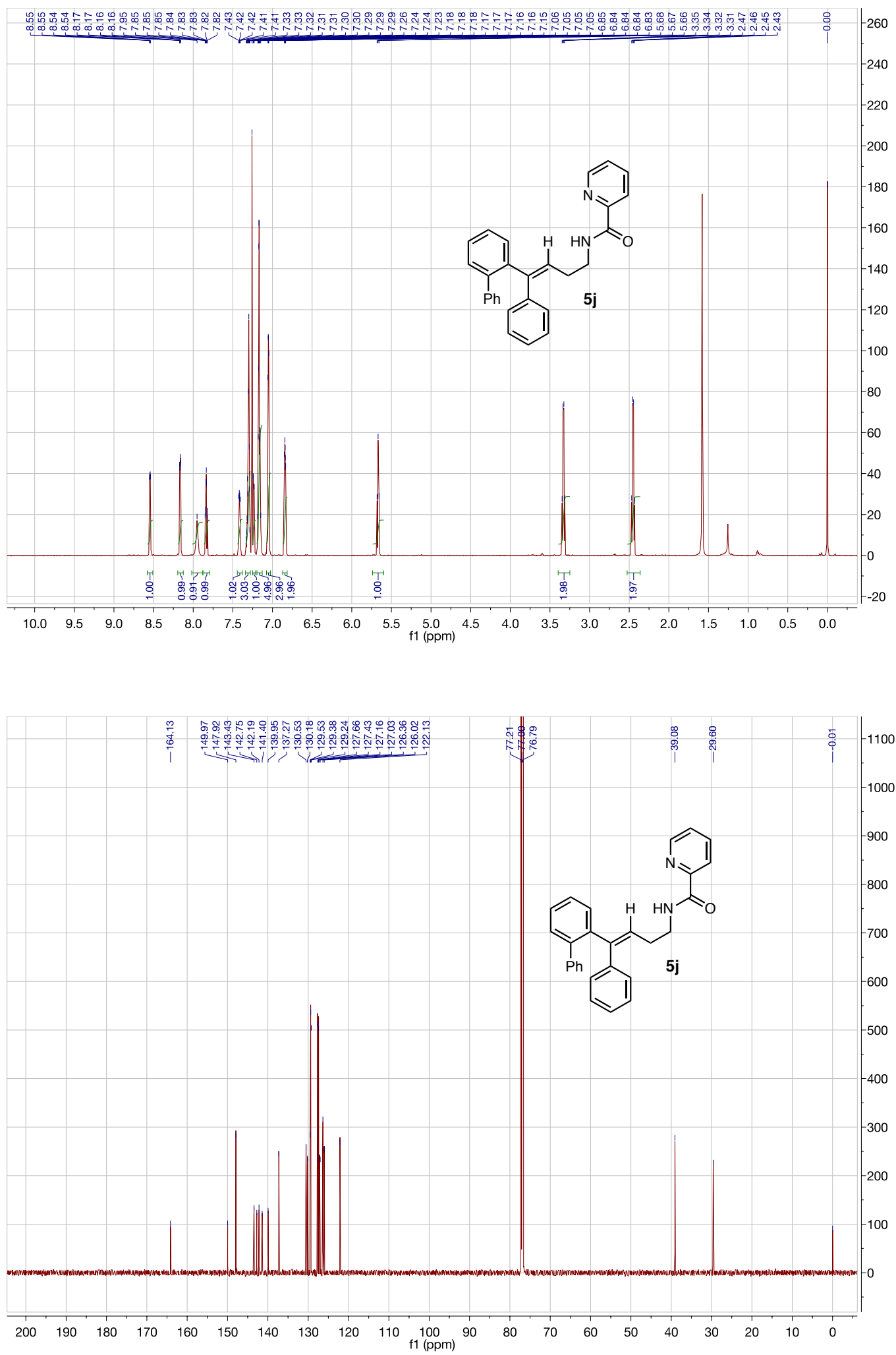

S-123 

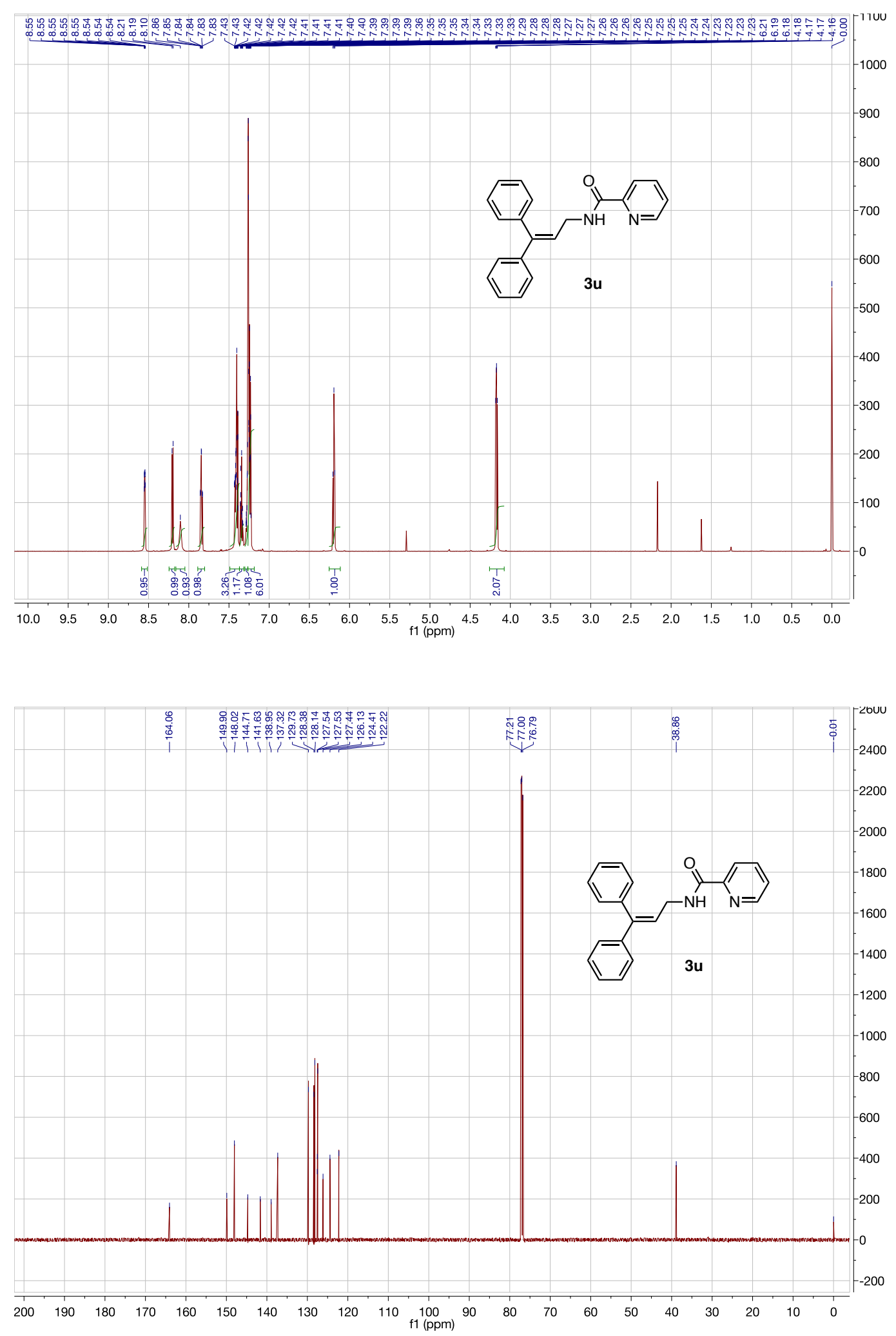

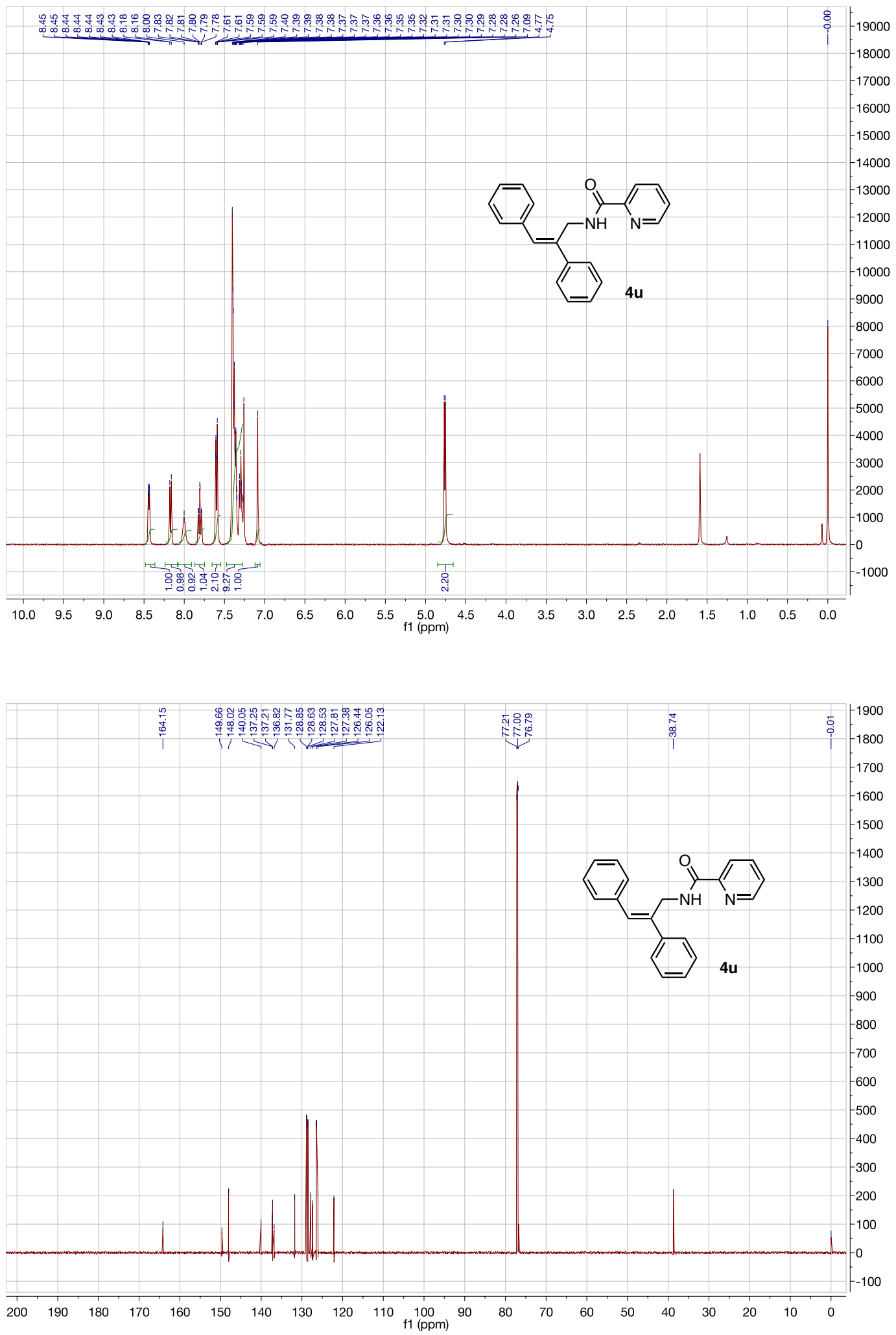

S-125 

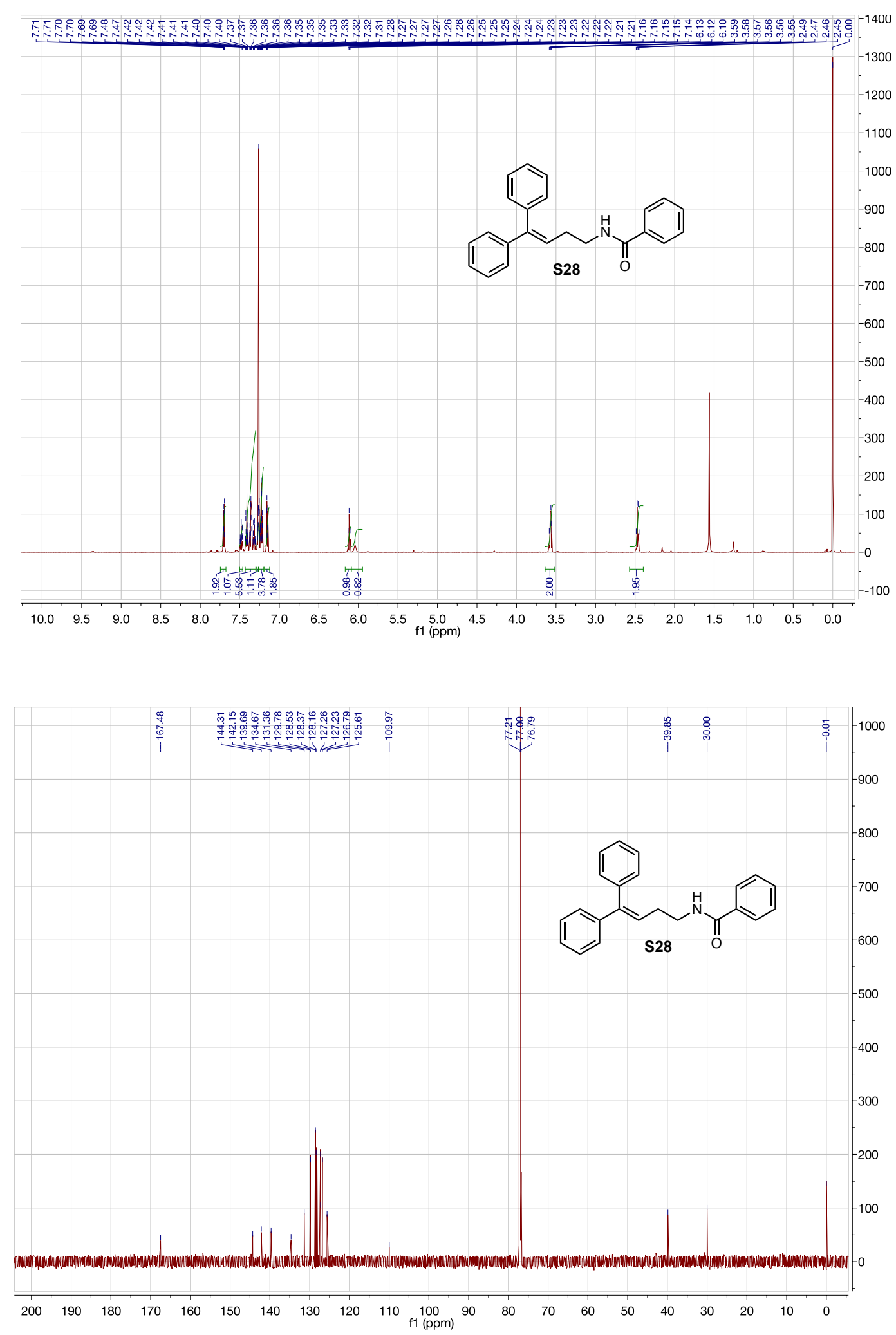

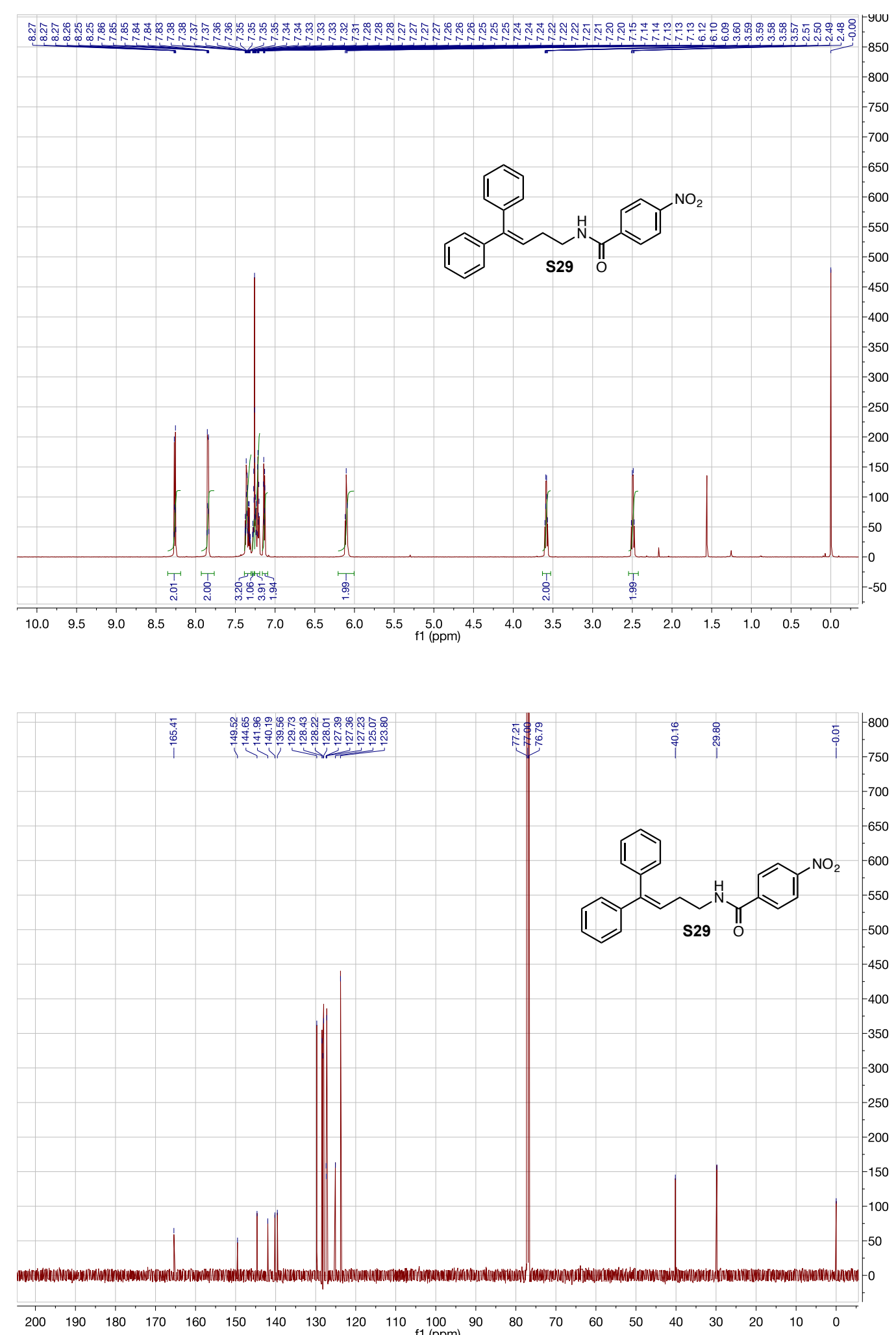

S-127 

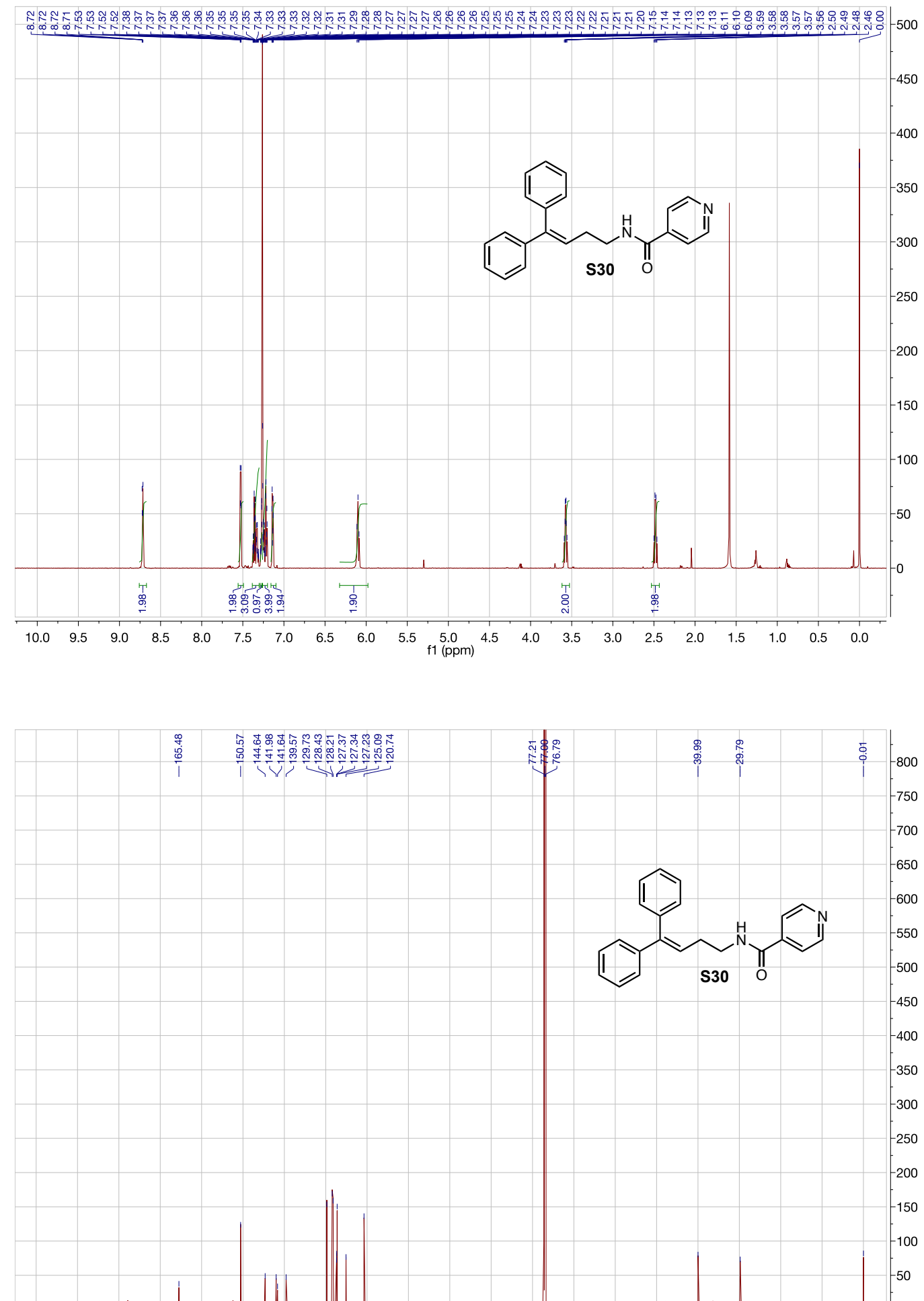

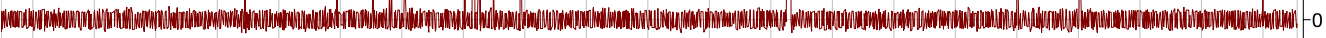

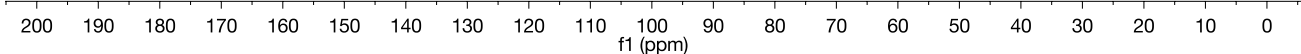

S-128 

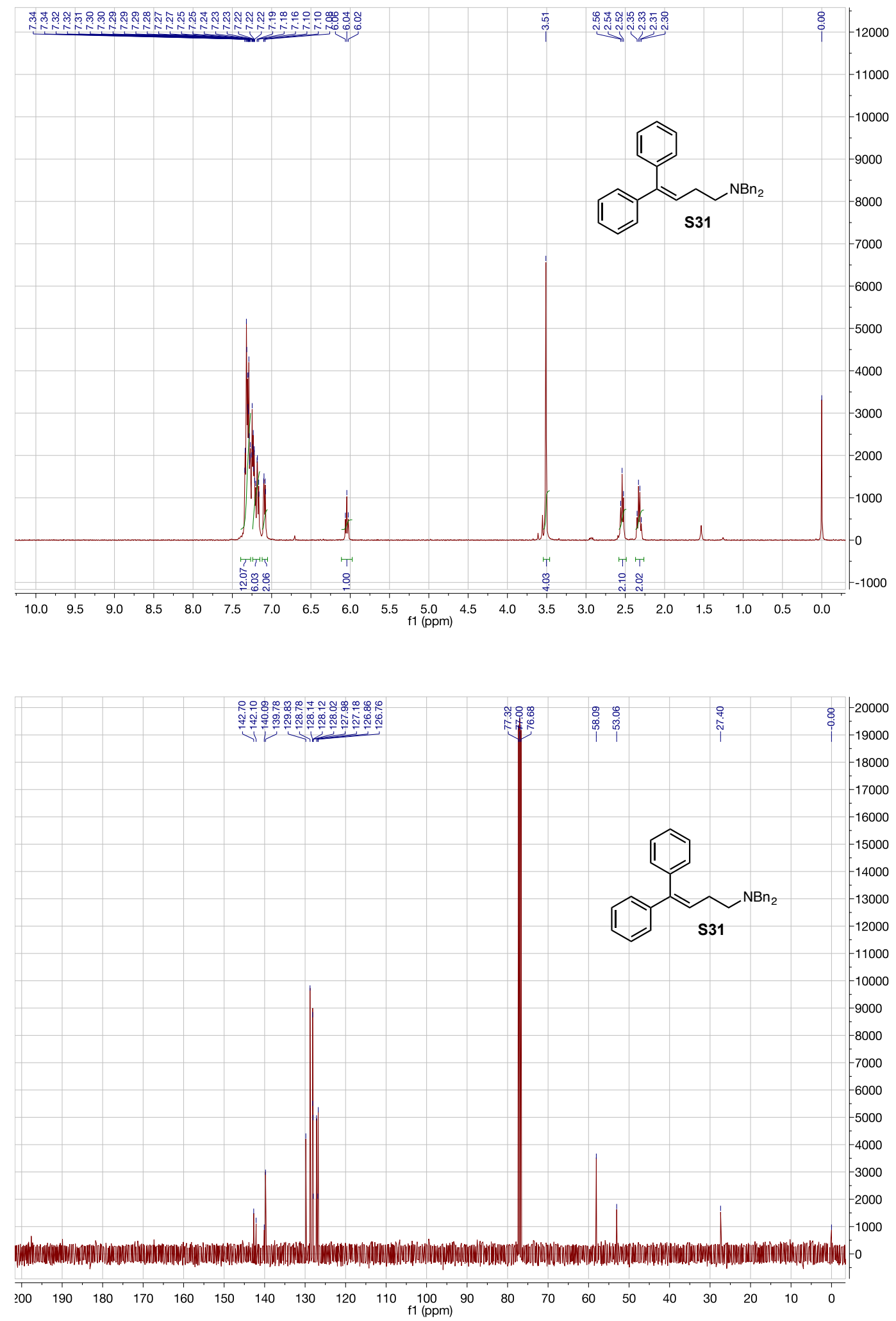

S-129 

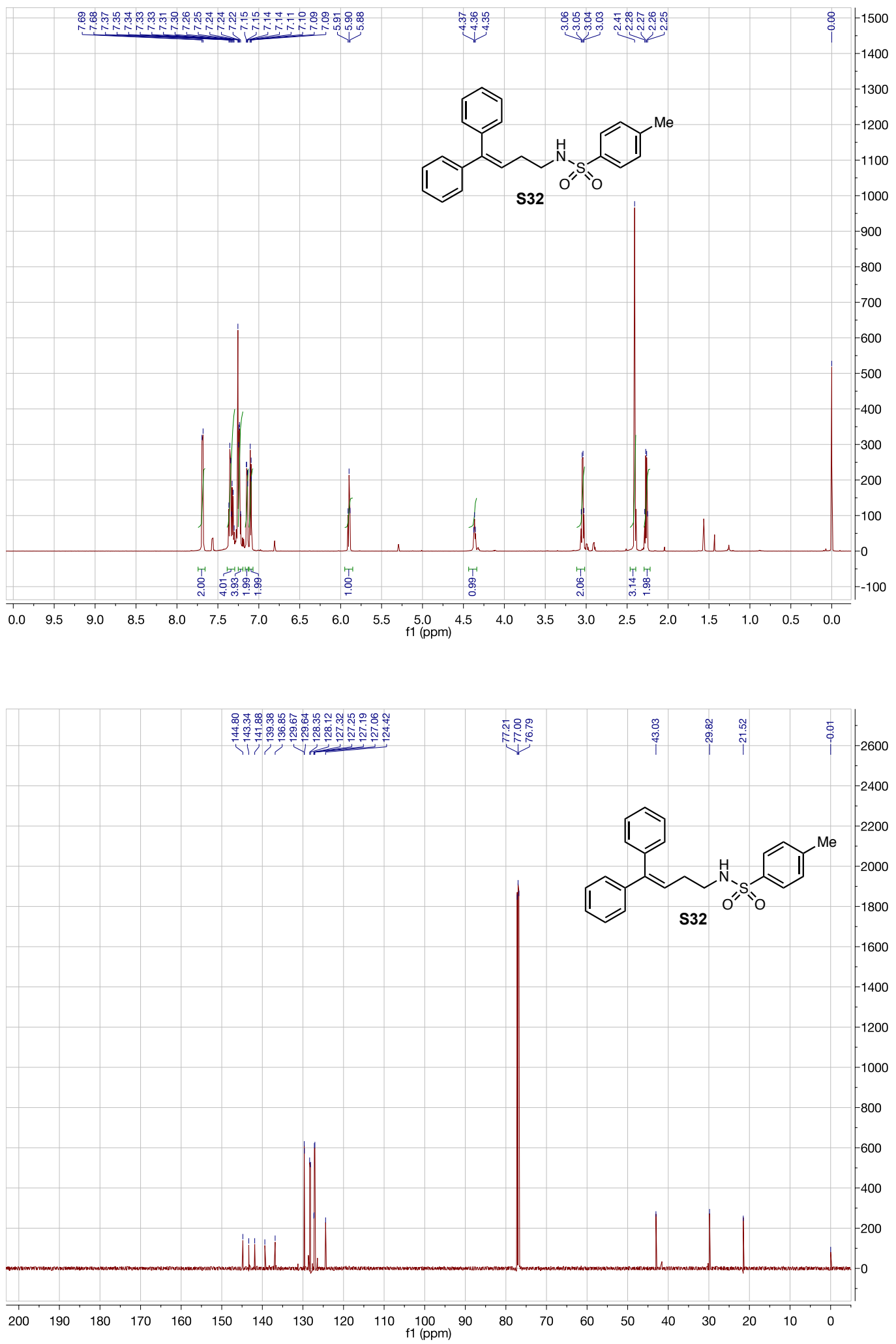

S-130 

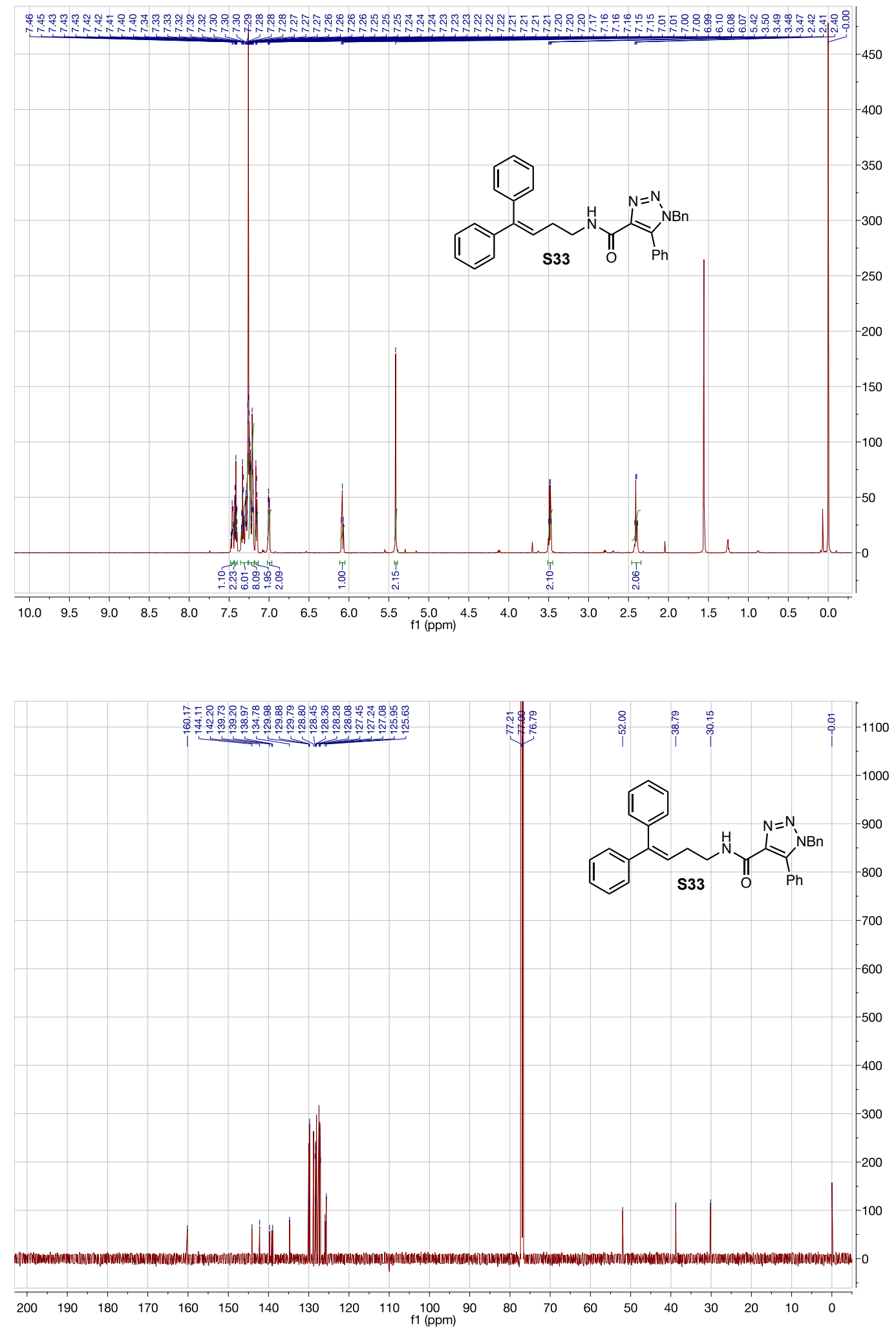

S-131 

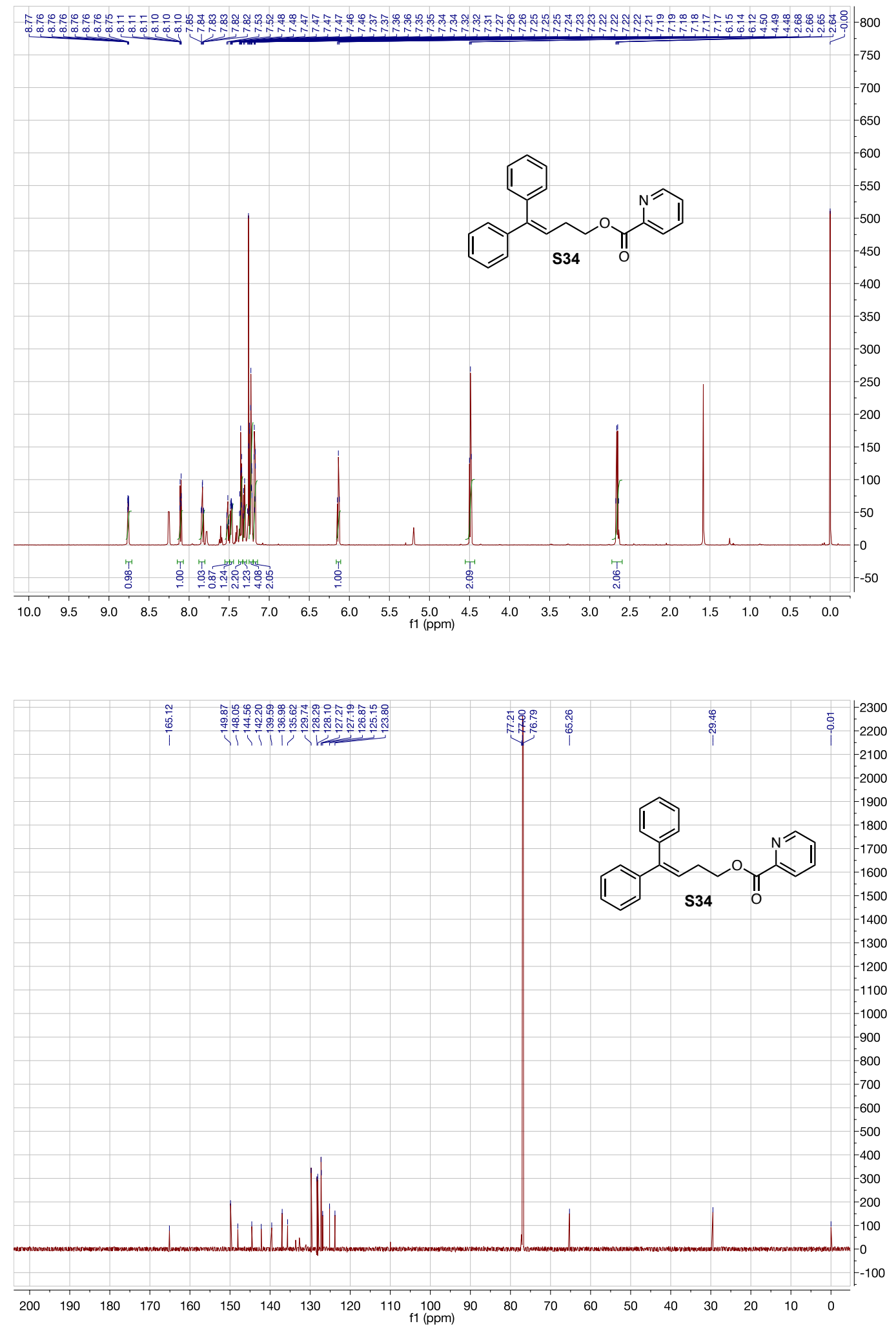

S-132 

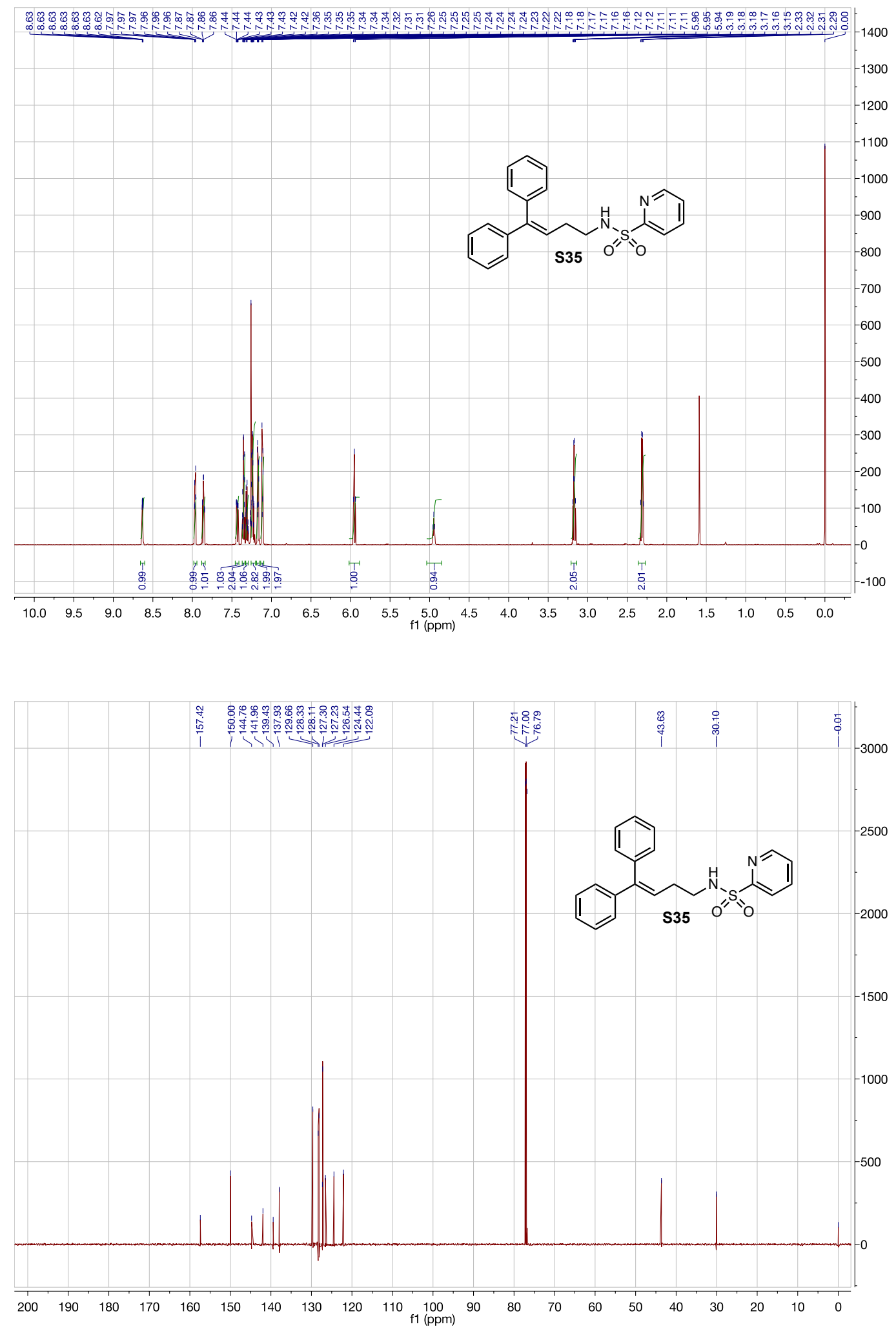

S-133 

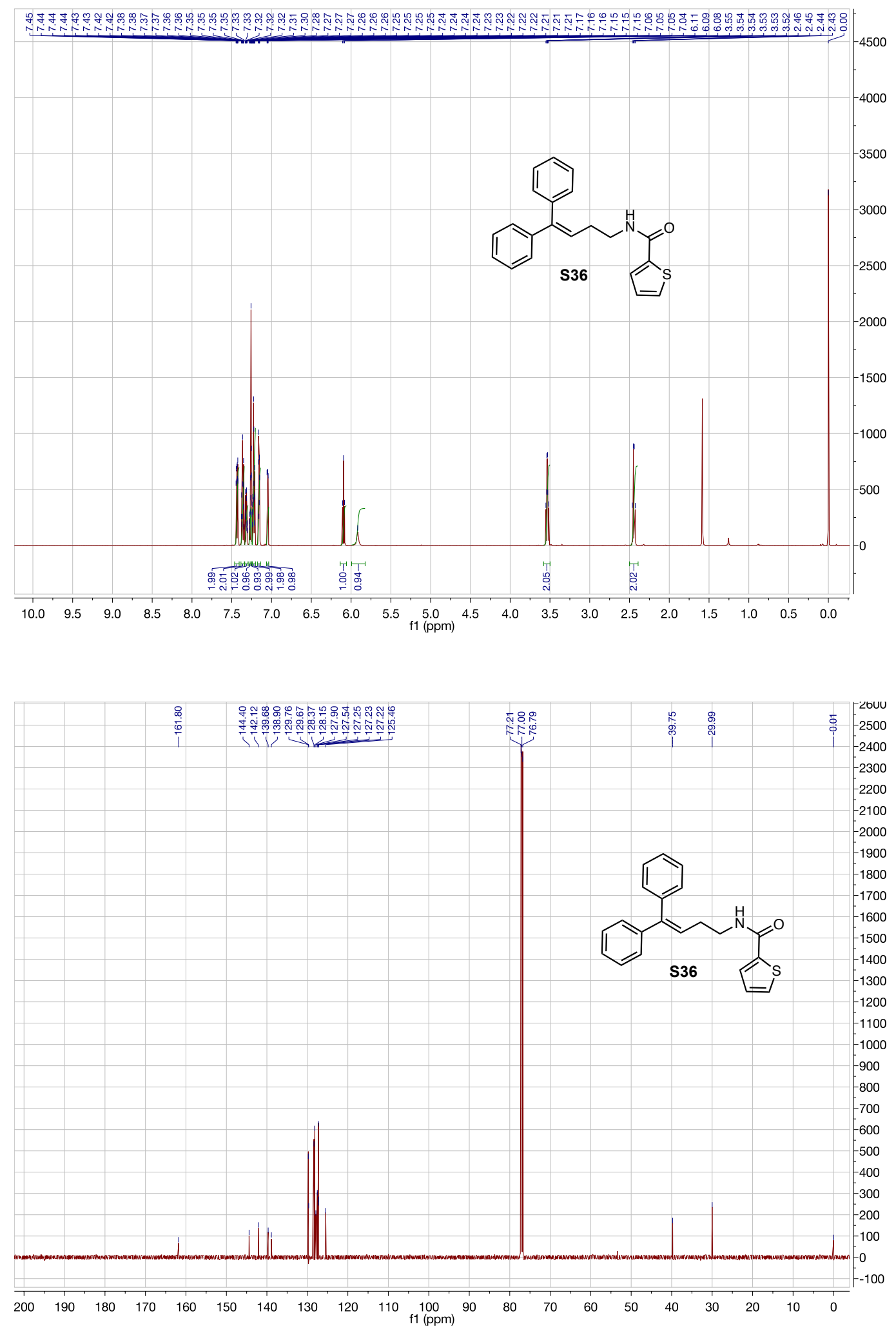

S-134 


\section{NOESY SPECTRA}

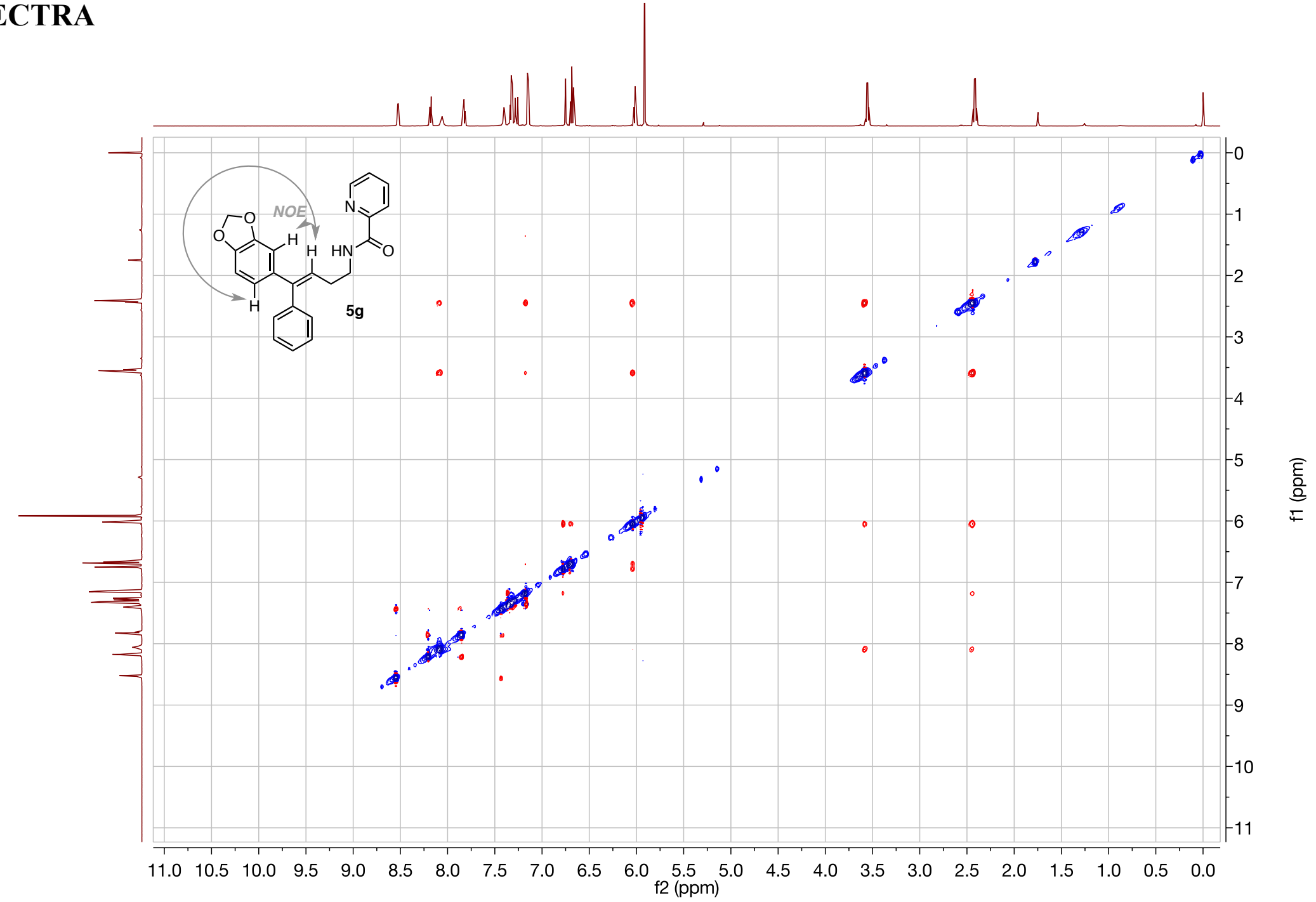




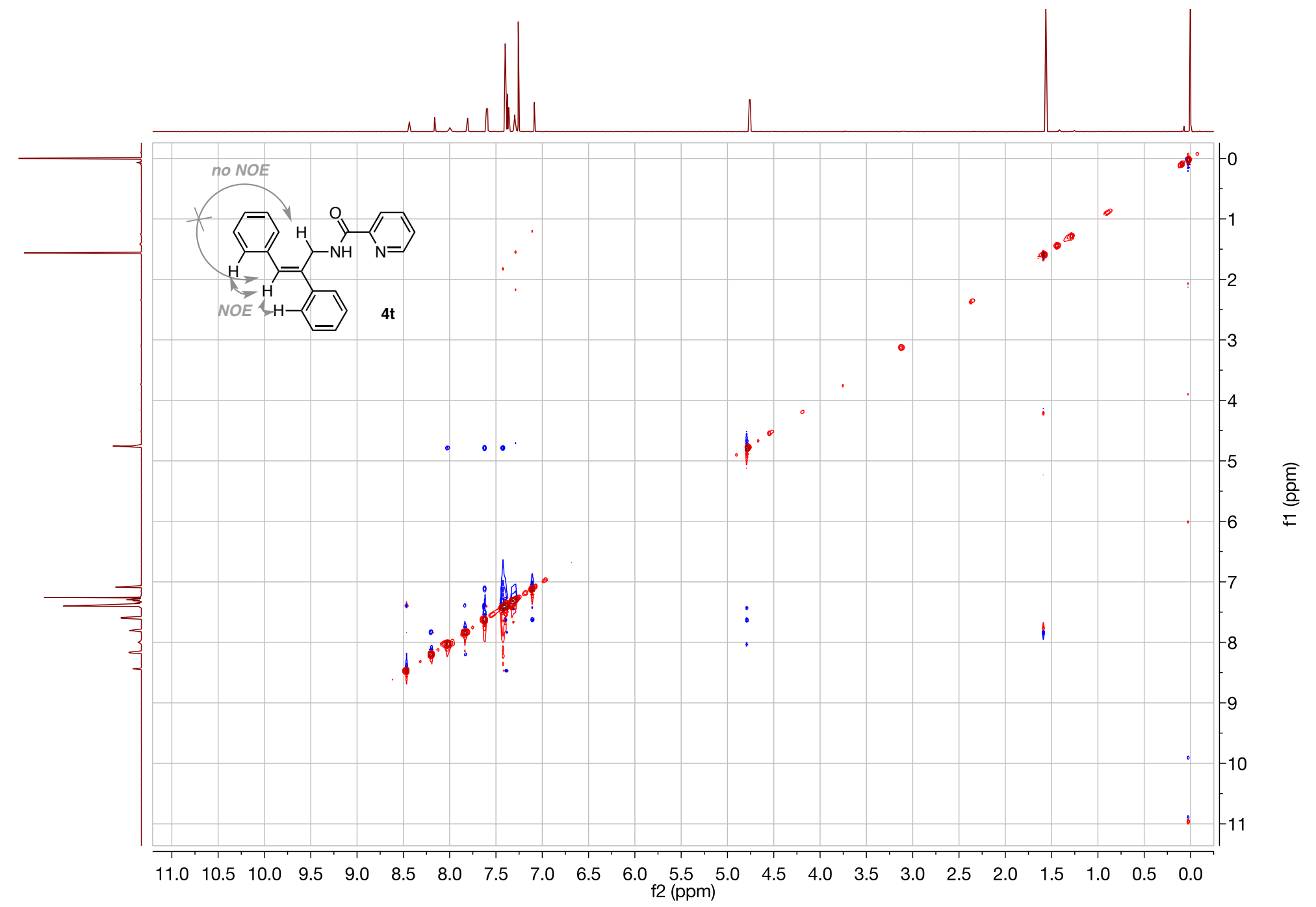

S-136 